
This volume is the natural outgrowth of a sequence of research activities on access-tojustice problems carried out in Florence under the general direction, of Mauro Cappelletti between 1971 and 1979. At the conclusion of the Florence Access-to-Justice Project, a major international conference was organized to report on the Project's findings (published by Sijthoff \& Noordhoff in a four-volume series entitled "Access to Justice") both to theoreticians and to policy-makers and practitioners active in this field. The purpose of the conference was not only to disseminate the Project's results but also to formulate recommendations for the future. Eleven reports were prepared by leading scholars from Europe and the United States and are presented here together with an introduction by Mauro Cappelletti and Bryant Garth. The book not only provides an overview of access-to-justice developments in the last couple of decades - a very active period in the access movement - analyzing the issues and pointing out the pitfalls and the lessons to be learned, but also puts forward suggestions for further research and reform activities and attempts to assess the future direction of the access-to-justice movement.

Using a comparative and interdisciplinary methodology, these essays set out to tackle one of the most pressing challenges of modern society: how to make law and justice readily and equally available to all. 

Digitised version produced by the EUI Library in 2020. Available Open Access inc Cadmuss, EEUIResearchhRepositoryy. 
PUBLICATIONS OF THE EUROPEAN UNIVERSITY INSTITUTE PUBLICATIONS DE L'INSTITUT UNIVERSITAIRE EUROPÉEN PUBLICATIES VAN HET EUROPEES UNIVERSITAIR INSTITUUT PUBBLICAZIONI DELL'ISTITUTO UNIVERSITARIO EUROPEO DET EUROPÆISKE UNIVERSITETSINSTITUTS SKRIFTER VERÖFFENTLICHUNGEN DES EUROPÄISCHEN HOCHSCHULINSTITUTS



BADIA FIESOLANA - FIRENZE 


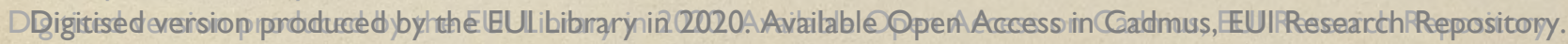




\title{
ACCESS TO JUSTICE AND THE WELFARE STATE
}

\author{
Edited by \\ MAURO CAPPELLETTI
}

With the assistance of

JOHN WEISNER and MONICA SECCOMBE

SIJTHOFF: Alphen aan den Rijn KLETT-COTTA: Stuttgart
BRUYLANT: Bruxelles

LE MONNIER: Firenze 
I.S.B.N. 9028625410 Sijthoff

(C) 1981 European University Institute

Stabilimenti Tipografici «E. Ariani » e «L'Arte della Stampa » - Firenze Manufactured in Italy - Imprimé en Italie. 


\title{
FOREWORD
}

by

\author{
MAURO CAPPELLETTI
}

As is explained in the following Introduction, this Volume is the natural outgrowth and conclusion of a sequence of research projects beadquartered in Florence - first at the Institute of Comparative Law of the University of Florence and at the Florence Center for Comparative Judicial Studies, and, since 1976, at the European University Institute. These projects culminated in the publication in 1978-79 of a fourvolume (six-book) Series entitled "Access to Justice." 1

Upon the publication of this Series it became clear, however, that a further effort should be made. The policy-oriented results of such a vast, comparative and interdisciplinary study bad to be made accessible to "decision-makers" - legislators and others - in order to prevent the immense wealth of information, critical analyses, and practical proposals produced by a coordinated international team of so many experts from merely ending up on the dusty shelves of libraries. The European University Institute and its President, Max Kobnstamm, encouraged the suggestion that a conference be organized to discuss the results of the study with a threefold purpose:

a) to acquaint decision-makers - especially, but not only, from Europe and North America - with the institutions, findings, and ideas discussed in the Series;

b) to establish lines of communication between decision-makers, practitioners, and academics of Western countries in order to encourage on-going collaboration on these difficult and most important issues of justice system design; and

${ }_{1}$ The Florence Access-to-Justice Project (M. Cappelletti, gen. ed.), Vols. 1-4, Alphen aan den Rijn (Holland) \& Milan, Sijthoff and Noordhoff \& Giuffrè, 1978-1979. 
c) to formulate an agenda for future action - not only for research, but also, and primarily, for practical action, that is, the enactment of legislative, judicial, and more generally political reforms.

To this end, a number of internationally known experts were requested to prepare "European" and "American" reports, while a further and larger number of experts, generally leading decision-makers and practitioners, were requested to act as "commentators" upon the various reports circulated well in advance of the conference. The present Volume includes, in addition to an Introduction (which is meant primarily to give a synthesis of the conference discussions), a revised version of the reports - revised, that is, on the basis of both the commentators' remarks and the conference discussions.

The title of the Volume and its subdivision into four Parts reflecting the four conference sessions - are best explained by reference to the "philosophy" and "structure" of the Access-to-Justice study. The Series' philosophy was rooted in an analysis of the inspiring force bebind some basic developments and reforms of modern Western societies. This inspiring force can be summarized in the idea of the "welfare state," i. e., the need for a promotional, activist state to make the new "social rights" effectively accessible to all, while recognizing, and indeed reinforcing, the ideal of private, individual freedom and initiative. The structure of the study was organized around a threephase sequence of those basic developments, which in our view has characterized - with important variables from country to country, of course - the evolution of modern systems in the last few decades.

The first stage - or "wave" - of this reform movement has been marked by a large number of programs and attempts to make the legal system ("justice") more accessible to the poor, especially through the initiation of more efficient systems of legal aid and advice. The second development, of more recent origin, has revolved around the efforts, which in many countries are still embryonic, to provide legal representation for otherwise unrepresented or underrepresented "diffuse," "fragmented," or "collective" interests, including, notably, consumer and environmental interests, as well as those of racial minorities, the handicapped, women and the aged. This development presents scholars and decision-makers with a problem which is basically common to the various countries. While legal services were traditionally defined in a two-party litigational context, in the welfare state they relate more and more to representation of, and clashes between, groups and group in- 
terests which have not been traditionally cast in litigational forms. This requires fundamental adjustments of our thinking about law and justice in welfare state situations. Finally, the third stage of reforms, generally of an even more recent origin, incorporates and yet goes much beyond the first two; it focusses on the entire dispute processing machinery, rather than on just providing legal representation to disadvantaged interests and groups. In particular, simplification of the substantive law and creation of alternatives to courts, lawyers, and litigation have become especially important within this reform trend, for courts, lawyers, and litigation are very costly modes of access to the law. In addition, in certain types of cases alternatives may provide a solution which is not only more economical, quicker and more efficient, but also of a better "quality." For instance, provided the parties are assured a comparable bargaining strength, "mending" solutions such as mediation and conciliation are always preferable to "contentious" adjudication whenever valuable relationships of a durable character are at stake.

Whereas the first three Parts of the present Volume reflect the sequence of those three phases in the "access-to-justice movement," the fourth Part is intended as a reflection upon the basic raison d'être of the movement itself, its strengths and weaknesses, its successes, failures, and (most important today) the possible backlash against it. There is, of course, growing discontent today with the very idea of a welfare state and its implications - the "orgy of legislation" and "big government." The economic crisis which also characterizes our present days has added much fuel to that discontent. This and many connected problems were discussed at the conference - and are discussed throughout this Volume, especially in Part Four. While I refer the reader to the Introduction for an attempt to sum up such discussions, it should only be noted bere that, to a large extent, the "third wave" in the access-to-justice movement may well provide an answer to - indeed, it may have been stimulated by - such economic crisis. The search for less formal, less expensive, less "juridical" modes and alternatives can surely be seen, in part, as an attempt to continue the quest for access notwithstanding the "straitened budgets" of the governments of our day and, perhaps, of the years to come. 
It is my pleasant duty to thank here all those who participated in the conference. ${ }^{2}$ Also, my special gratitude goes to the European University Institute, which provided the intellectual atmosphere, the organizational conditions and the historic setting which proved so important to make of such a diverse group of participants - coming from many different countries and professions - a cohesive and unified group. The Commission of the European Communities and the Ford Foundation belped not only financially but also with the invaluable participation in the conference of several of their higher officers. Professors Earl Johnson, Jr., and Bryant Garth, my principal associates during the many years of the access-to-justice research, were instrumental in the promotion of the extensive participation of U.S. experts. John Weisner's and Monica Seccombe's assistance in the organization of the conference, in the editing of the reports and throughout the publication process was essential. Of the many others who gave generous belp I would like to mention and thank especially Kim Economides, Gene Gelernter, and Joseph Weiler, as well as Bobbie Rawle Longinotti and Evie Valerio.

Florence, July 1980.

2 See the list of participants, infra, at 361-365. 


\section{TABLE OF CONTENTS}

Foreword by Mauro Cappelletti $\ldots \ldots \ldots \ldots \ldots \ldots \ldots \ldots \ldots$ v

Access to Justice and the Welfare State: An Introduction by Mauro Cappelletti and Bryant Garth ...................

I. Preliminary Issues: The "Wave" Metaphor, Comparability, and

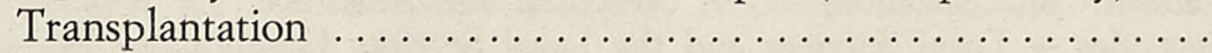

II. Session One. Legal Aid for the Poor ................

III. Session Two. Protection of Diffuse and Fragmented Interests .

IV. Session Three. Beyond Legal Representation: Dispute Processing and Non-Judicial Alternatives .................. 14

V. Session Four. Access to the Legal System and the Modern Welfare State ........................... 20

VI. Prospects for Future Action .................. 23

Part One

LEGAL SERVICES FOR THE POOR

The First Wave in the Access-to-Justice Movement

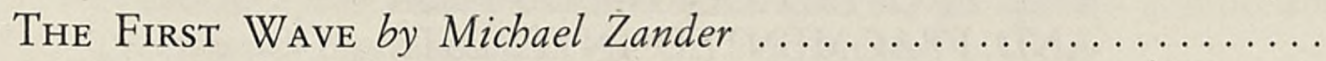

I. The Need for a Legal Aid System Based on Governmental



II. No Necessary Incompatability Between State Funding and the Continuing Independence of the Legal Profession ..........

III. Mixed Delivery Systems Are Likely to Be Best ..........



V. The Desiderata for a Legal Aid Scheme ...............

$A$. The Widest Coverage for the Scheme, $34 ; B$. The Merits Test for the Grant of Legal Aid Should Not Be Unduly Stringent, 35; C. The Means Test Limits Should Include as Great a Proportion of the Population as Possible, 36; D. If There Is a Contribution System, It Should Not Be Such as to Deter Eligible and Deserving Applicants, 37; E. The Limited Liability System for Legal Aid Costs Should Include Not Only the Costs of the Applicant But Also His Opponent's, Should the Applicant Lose, 37; F. Ideally, the Legal Aid System Should Also Cover the Costs of the Non-Legally-Aided Defendant 
Who Successfully Resists Proceedings Brought under Legal Aid, 38; G. Remuneration of Lawyers for Legal Aid Work Must Be Sufficiently High to Be Attractive, 38; $H$. Adequate Funding at the National Level, 39; I. Should Funding for the Public Sector Be on a Central or a Local Basis?, 40; J. How Large Should the Public Sector in Legal Services Be? 41; K. Where Should Staff Offices Be Situated?, 41; L. Can Ways Be Found to Create Controls over the Quality of Legal Work?, 42; M. There is a Need in Every System for Adequate Statistics and Research, 43; N. There is a Need in Every Legal Aid System for the Involvement of Laymen and for External Review Bodies, 44.

Legal Services to the Poor: An American Report by Gary

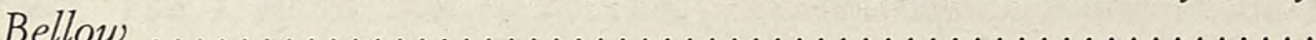

I. The Controversial Past

A. The Sixties - Legal Services and the War on Poverty, 49; 1. Local Autonomy, 52; 2. Staff Lawyers, 52; 3. Indigent Clients, 52; 4. "Law Reform" Specialization, 53; 5. Structural Independence, 53; B. The Seventies - Legal Services and the Legal Services Corporation, 54.

II. The Uncertain Future $\ldots \ldots \ldots \ldots \ldots \ldots \ldots \ldots \ldots$

A. The Problem of Political Support, 58; B. The Strains of Practice, 61; C. The Trend Toward Insularity, 64.

III. Some Concluding Remarks .................

A. The "Delivery" Problem, 66; B. The "Reform" Problem, 67.

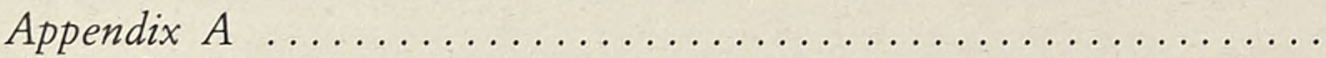

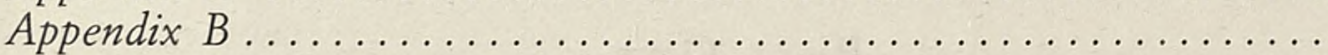

Part Two

THE PROTECTION OF DIFFUSE AND FRAGMENTED INTERESTS

The Second Wave in the Access-to-Justice Movement

Public Interest Litigation: A Comparative Survey by Hein

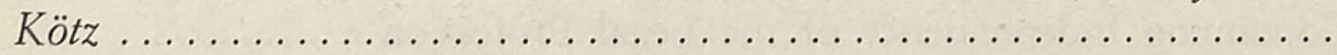

I. Introduction $\ldots \ldots \ldots \ldots \ldots \ldots \ldots \ldots \ldots \ldots \ldots \ldots \ldots \ldots \ldots \ldots \ldots \ldots \ldots$

II. Monetary Incentives $\ldots \ldots \ldots \ldots \ldots \ldots \ldots \ldots \ldots \ldots \ldots \ldots \ldots \ldots \ldots \ldots$

A. Multiple Damages, 89; B. Relief from Attorneys' Fees and Court Costs, 90; 1. The United States, 90; 2. Germany, 93.

III. Class Actions and Shareholders' Derivative Suits .........

A. Class Actions, 96; B. Shareholders' Derivative Suits, 99.

IV. Public Interest Suits $\ldots \ldots \ldots \ldots \ldots \ldots \ldots \ldots \ldots \ldots \ldots \ldots \ldots \ldots \ldots \ldots \ldots$

A. Relator Actions in England, 102; B. Suits by Associations in France and Germany, 104; 1. France, 104; 2. Germany, 106; 3. Suits 
by Associations as European Analogues of the Class Action, 107; C. Standing in Administrative Proceedings, 108; D. Citizen. Suits (Popularklagen), 110; E. Governmental Agencies, 111.

V. Potential for Future Action $\ldots \ldots \ldots \ldots \ldots \ldots \ldots \ldots$

VI. Conclusion $\ldots \ldots \ldots \ldots \ldots \ldots \ldots \ldots \ldots \ldots \ldots \ldots \ldots$

Civic Justice Through Civil Justice: A New Approach to Public Interest Advocacy in the United States by Louise

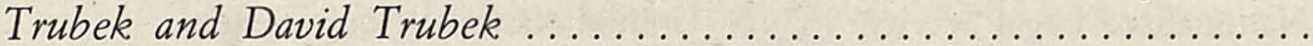

I. The Classic Public Interest Law Approach to Representing In-

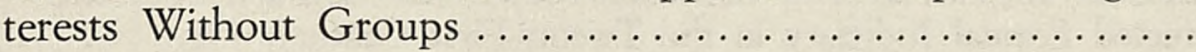

$A$. The Ideology of Public Interest Law, 122; B. Institutionalizing the Classic Approach, 123; 1. The Public Interest Law Firm, 124; 2. Public Interest Law Efforts by Private Law Firms, 124; 3. Governmental Advocates, 125; C. The Current Status, 126; 1. Foundations, 127; 2. Bar Support, 127; 3. Attorneys' Fees, 128; 4. Governmental Support, 130.

II. Limits of the Classic Approach .................

III. Toward a More Comprehensive Strategy for Participation ...

A. New Trends in Consumer Participation, 135; 1. Citizen Activism, 136; 2. Citizen-Government Planning in Human Services Delivery Systems, 137; 3. Interest Representation on Regulatory Boards, 137; 4. Government Efforts to Strengthen Private Consumer Advocacy Groups, 138; 5. Direct Contact Between Consumer Advocates and Business, 140; B. A Strategy for More Effective Representation, 140; 1. A Potential System, 141; 2. Strengthening the Elements, 142; 3. Establishing Linkages Between the Elements, 142; $a$. Linking consumer representatives on government bodies with external advocacy groups and individual advocates, $142 ; b$. Linking the individual complainant with external advocacy groups, $143 ; c$. Linking consumers who deal with business with external advocacy groups and government consumer representatives, 143.

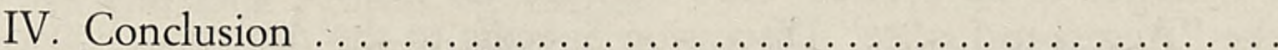

Part Three

BEYOND LEGAL REPRESENTATION:

DISPUTE PROCESSING AND

NON-JUDICIAL ALTERNATIVES

The Third Wave in the Access-to-Justice Movement

Justice in Many Rooms by Marc Galanter .................

I. The Centrifugal Perspective: Access "in the Shadow of the Law" ..................................

II. The Law in the Shadow of Indigenous Regulation ........ 
III. Access to Justice in a Post-Centralist World: A Dialogue of Shadows . . . . . . . . . . . . . . . . . . . . . . . . . . . . 169

IV. Conclusion $\ldots \ldots \ldots \ldots \ldots \ldots \ldots \ldots \ldots \ldots \ldots \ldots$

The Justice System of the Future: Four Scenarios for the Twenty-First Century by Earl Johnson, Jr. ..............

I. The First Scenario: The Perfected Formal Judiciary ........ A. Nationalized Legal Service, 185; B. Unified National Court System, 187; C. Technologically Advanced Proceedings, 188; D. Economic Settlement Incentives, 190; E. What People Are Saying About the Perfected Formal Judiciary in the Twenty-First Century, 193.

II. The Second Scenario: Maximum Feasible Deformalization of

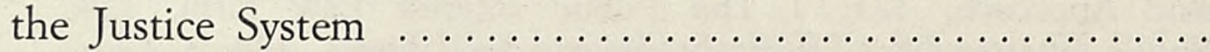

A. Neighborhood Justice Centers, 195; B. Specialized Forums, 196; C. The Role of the Courts After Maximum Feasible Deformalization, 202; D. Critics of Maximum Feasible Deformalization, 203.

III. The Third Scenario: The Systems Analysis Approach .......

A. The Systems Analysis Approach to the Traditional Functions of the Courts, 204; 1. Economic Compensation through the Income Tax and Transfer Agency, 205; 2. Expanded Powers of the Courts to Compel Present or Future Conduct, 207; 3. New Policies for Status Changes, 208; 4. New Forums for the Remaining Disputes, 209; B. What People Say About the "Systems Analysis" Justice System of the Twenty-First Century, 209.

IV. The Fourth Scenario: A "Lowered Expectations" Program . .

Conditions of Legal and Political Culture Limiting the Transferability of Access-TO-Law InNovations by Erhard Blan-

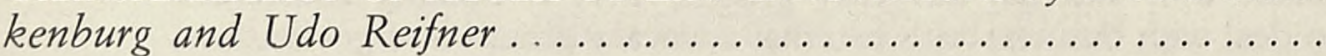

I. The Question to be Treated: How Far Are the "Three Waves" of the "Access-to-Justice" Discussion Specific to the American

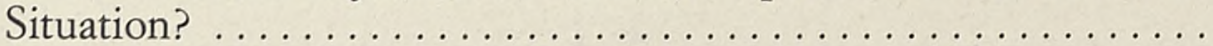

II. The Social Conditions of the "Access-to-Law" Movement . . . A. The Innovative Cases: The U.S.A., England, and the Netherlands, 219; B. A Conservative Case: The Federal Republic of Germany, 222.

III. The German "Peace-under-the-Law" ("Rechtsfriede") Movement as an Attempt to Pacify the Social Antagonisms of Industrialization $\ldots \ldots \ldots \ldots \ldots \ldots \ldots \ldots \ldots \ldots \ldots$

A. Legalization of Social Disputes by Free Legal Advice, 228; $B$. "Legal Welfare" as the Ideology of the "Peace-under-the-Law" Movement, 231; 1. Welfare Capitalism and "Volksrecht" ("People's Law"), 232; 2. Social Reformism and the Ideology of Partnership, 234; 3. From the "Peace-under-the-Law" Movement to "National Socialist Legal Care", 237; 4. After 1945: Restricting Competition for Lawyers' Services, 241. 
IV. "Access to the Law" and the German Legal Culture ..... 243 A. Structural Restrictions to Innovativeness, 243; B. A Possible Alternative: Integrating Legal Aid into Existing Institutions, 246.

\author{
Part Four \\ ACCESS TO THE LEGAL SYSTEM \\ AND THE \\ MODERN WELFARE STATE
}

Claims, Disputes, Conflicts and the Modern Welfare State by Lawrence Friedman .......................... 251

I. A Note on History ..................... 252

II. The Rule of Law and Its Enemies .............. 255

III. Group Interests .......................... 259

A. The Importance of Organization, 259; B. Judicial Review: Some Pros and Cons, 261; C. The Litigation Explosion, 265.

IV. Individual Interests ......................... 266

V. Subject Interest .......................... 270

Access to the Legal System and the Modern Welfare State: American Continuities by Martin Shapiro .............. 273

I. Introduction .......................... 273

II. Historical Perspective of American Access to Justice ..... 275 A. The Frontier, 275; B. Urban America, 277.

III. Court Overcrowding ......................... 283

IV. Legal Assistance in Criminal Cases .................. 285

V. The Due Process Revolution ...................... 288

VI. The Quest for Equality . . . . . . . . . . . . . . . . . . . 289

VII. Justice and Politics ............................ 290

VIII. Conclusion ................................... 292

Access to the Legal System and the Modern Welfare State: A European Report From the Standpoint of an AdministraTIVE LAWYER by Harry Street ......................... 295

I. Increased Power of Public Officials over Individuals ...... 295

II. Government Regulation of the Economy and Industry . . . . . 297

III. Expropriation of Land and Control of its Use . . . . . . . 299

IV. Government Benefits ......................... 300

V. Consumerism .............................. 301

VI. Licensing ............................. 302

VII. Enforcement of Health and Safety Standards ........... 303 
VIII. Special Tribunals for Protecting the Weak Individual Against

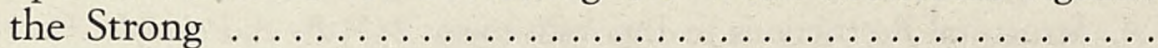

A. Rent Control, 304; B. Employer-Employee Relationships, 304;

C. National Health Service, 305.

IX. A First General Conclusion ......................

$X$. The Problems of Reform in the Area of Welfare State Law . A. Legal Education, 307; B. Para-Legals, 307; C. Legal Aid, 308; $D$. Trade Unions and Legal Representation, 308; E. Expert Evidence, 309; F. Class Actions (Test Cases and Relator Actions), 309; G. Conciliation, 310; H. Government Information, 311.

XI. Programme for Future Action . . . . . . . . . . . . . . . .

A. Private Practice in Poorer Areas?, 312; B. Experimentation and Diversity, 313.

The Quest for Justice by André Tunc $\ldots \ldots \ldots \ldots \ldots \ldots$

I. Access to Legal Justice .......................

A. Financial Barriers, 317; B. Knowledge of Rights and of Cause of Action, 320; C. Small Claims, 320; D. Diffuse and Fragmented Interests, 321; E. Specialized Courts, 323; F. Uncertainty of the Law, 325; G. Unsatisfactory Laws, 326; $H$. Prospective Overruling, 326; I. Psychological Costs, 327; J. Witnesses, 328; K. Slowness, 328; L. Jurisdictional Clarity, 329; M. Conclusion, 329.

II. Access to the Machinery of Justice Specific to the Welfare State $A$. The Emergence of Social Rights, 331; B. The Creation of the Welfare State and Problems of Access to Justice, 333; C. Some Specific Problems and Trails Toward Access to Justice in the Welfare State, 338; 1. Efforts to Clarify and Publicize Legal Rules, 339; 2. Administration "With a Human Face", 341; 3. Control of Administrative Action, 342; 4. Computers and the Danger of a Police State, 349.

III. Access to "Justice" $\ldots . \ldots \ldots \ldots \ldots \ldots \ldots \ldots \ldots \ldots$. . . . . . . .

A. "Justice", 350; B. Limitations and Risks of the Access-to-Justice Approach, 352; C. Contradictions in the Reform Effort, 354; D. The Problems of Government Regulation, 354; E. The Impossible Quest for Justice, 358.

Appendix: Access to Justice Conference, October 15-18, 1979: List of

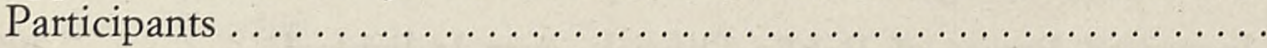




\title{
ACCESS TO JUSTICE AND THE WELFARE STATE: AN INTRODUCTION
}

\author{
by \\ MAURO CAPPELLETTI \\ Professor of Law, European University Institute \\ and \\ BRYANT GARTH \\ Assistant Professor of Law, Indiana University
}

The concept "access to justice" encapsulates crucial questions not only for the legal profession and civil procedural scholars, but also for our society at large; and competing social concerns make these questions difficult to resolve. On one side is the concern with opening up courts and administrative agencies to disadvantaged groups and persons who have been unable to use those institutions effectively, if at all. Recognizing that formal, nineteenth-century rights of access were inadequate, since they amounted in practice to denials of effective access for much of the population, there has been an increasing effort in the twentieth century to move beyond a merely formal right. That effort, however, brings new problems. Access reforms adopted to aid large numbers of persons may come only at a relatively high price, particularly if they are confined to subsidized lawyers and to ordinary judicial procedures. The pressure of costs - especially in times of straitened governmental budgets, like the present - militates in favor of "wholesale justice," 1 which may in turn come only at the expense of the quality of justice. Quality and quantity in this area are inevitably in tension, making it very difficult to determine a proper balance between the values of access and justice. Even if that balance is found, there is a further tension between the goals of individual justice and social justice. The social goals of mass justice, including that of enforcing the "new rights"

1 See, e. g., Calabresi, Access to Justice and Substantive Law Reform: Legal Aid for the Lower Middle Class, in Access to Justice: Emerging Issues and Perspectives 169 (Alphen aan den Rijn/Milan, Sijthoff and Noordhoff/Giuffrè, Vol. III of the Florence Access-to-Justice Project Series, M. Cappelletti \& B. Garth eds., 1979); Friedman, Access to Justice: Social and Historical Context, in Access to Justice: Promising Institutions 3 (Alphen aan den Rijn/Milan, Sijthoff and Noordhoff/Giuffrè, Vol. II of the Florence Access-to-Justice Project Series, M. Cappelletti \& J. Weisner eds., 1978-1979). 
associated with what is commonly termed the welfare state, may conflict with some of the niceties of justice in individual cases. For several reasons, therefore, "access to justice" implies continuing social development, involving a constant debate about how much access to provide and how much and what kind of justice should result. While the contours of the debate have shifted considerably in recent years in favor of access, the issues are by no means resolved. This volume culminates a long effort to study these problems and point to some solutions.

The issues of access to justice have been the focus of several comparative projects centered in Florence and inspired by the principle that "the function of comparative study is not only to describe the law but to work for its improvement." 2 The first of these projects began in 1971 with an international conference in Florence on the core values essential to civil procedure, and it resulted in the publication in 1973 of the volume, Fundamental Guarantees of the Parties in Civil Litigation, ${ }^{3}$ containing a general report ${ }^{4}$ and sixteen national reports. The second major comparative project, which lasted for the rest of the decade, examined legal aid for the poor, ${ }^{5}$ the representation of "diffuse interests," 6 and then the entire field of "access to justice." 7

The Florence Access-to-Justice Project, funded by the Ford Foundation, the Italian National Council of Research (C.N.R.), and the European University Institute, undertook the task of providing a first level of comparative research into the problems of access to judicial machinery and potential solutions to those problems. The Project's method, reflected in the organization of the four volumes published in 1978 and $1979,{ }^{8}$ was to collect over twenty national

2 Quoted from the intervention of a leading comparative scholar, Professor René David, at the Florence Conference on Access to Justice.

${ }^{3} \mathrm{M}$. Cappelletti \& D. Tallon, Fundamental Guarantees of the Parties in Civil Litigation (Milan/Dobbs Ferry, N. Y., Giuffrè/Oceana, 1973).

4 Also published, with adaptations, in article form as Cappelletti, Fundamental Guarantees of the Parties in Civil Litigation: Comparative Constitutional, International, and Social Trends, 25 Stanford Law Review 651 (1973).

5 M. Cappelletti, J. Gordley, \& E. Johnson, Jr., Toward Equal Justice: A Comparative Study of Legal Aid in Modern Societies (Milan/Dobbs Ferry, N. Y., Giuffrè/Oceana, 1975).

6 M. Cappelletti \& J. Jolowicz, Public Interest Parties and the Active Role of the Judge in Civil Litigation (Milan/Dobbs Ferry, N. Y., Giuffrè/Oceana, 1975).

7 The Florence Access-to-Justice Project, Volumes I-IV (Alphen aan den Rijn/Milan, Sijthoff and Noordhoff/Giuffrè, M. Cappelletti gen. ed., 1978-1979).

8 Vol. I (in 2 books): Access to Justice: A World Survey (Alphen aan den Rijn/Milan, Sijthoff and Noordhoff/Giuffrè, M. Cappelletti \& B. Garth eds., 1978); Vol. II (in 2 books): Access to Justice: Promising Istitutions, supra note 1; Vol. III: Access to 
reports and examine them comparatively ${ }^{9}$ (Volume I); single out for intensive study those institutions that merited particular attention (Volume II); and focus finally on some of the key issues and perspectives that required further development (Volumes III and IV).

The present volume is not intended simply to be another in the Access-to-Justice Series. It is an effort to go beyond the previously published volumes, and for that reason a new international conference was held on October 15-20, 1979, at the European University Institute in Florence. Its theme was: "Access to Justice After the Publication of the Florence Project: Prospects for Future Action." This Conference on Access to Justice ${ }^{10}$ brought together in Florence about sixty persons, drawn mainly from Europe and the United States, and their task was to examine collectively the materials that had already been published and the phenomena there described. Conference participants came from academic life, private practice, the bench, and from policy-making positions related closely to the problems and proposals that have been the Project's concern. The participants accordingly brought both practical and theoretical insights to the Project's work. The conference on one level allowed them to obtain up-to-date information, exchange ideas, and discuss concretely what kinds of reforms are desirable and practical and how they might be implemented. Mr. A. D. M. Oulton of the Lord Chancellor's office in Great Britain, for example, shared with the participants his experiences on how reform proposals should be best formulated to obtain governmental support. In addition, the conference participants brought fresh viewpoints with respect to the theoretical analyses in the earlier volumes. They determined what issues were most salient from their vantage points, what insights or conclusions seemed more or less valid to them, and how generally to assess what we have termed the "access-to-justice movement."

This Introduction will highlight the points raised at the confer-

Justice: Emerging Issues and Perspectives, supra note 1; Vol. IV: Access to Justice: The Anthropological Perspective (Alphen aan den Rijn/Milan, Sijthoff and Noordhoff/Giuffrè, K.-F. Koch ed., 1979) [the volumes are hereinafter referred to as AccEss To JusTICE, Volumes I to IV, respectively].

9 The comparative analysis by the authors of this Introduction is also published in article form as Cappelletti \& Garth, Access to Justice: The Newest Wave in the Worldwide Movement to Make Rights Effective, 27 Buffalo Law Review 191 (1978).

10 A compte-rendu of the Conference, prepared by Professor Tunc, was published in 31 REVUe INTERNATIONALE DE DROIT COMPARÉ 836 (1979). The same periodical published an extensive analysis of the Access series by Professor David, Théorie et réalité dans l'application du droit: une enquête internationale sur l'accès à la justice, 31 REVUE INTERNATIONALE DE DROIT COMPARÉ 617 (1979). 
ence and in the papers presented there and revised for publication in this volume. It will not attempt to summarize descriptions and analyses that have already been made in previous volumes. ${ }^{11}$ The discussion here will essentially follow the organization of the conference, which took place in four sessions: 1) legal services for the poor; 2) the protection of diffuse and fragmented interests; 3 ) alternatives to lawyers, courts, and regular court procedures; and 4) access to the legal system and the modern welfare state. Before proceeding to discussion of individual sessions, however, it may be useful to emphasize a few key issues that cut through the individual sessions and surfaced throughout the conference. In particular, some issues implicit in the organization of the conference must be raised.

\section{Preliminary Issues: The "Wave” Metaphor, Compara- BILITY, AND TRANSPLANTATION}

The organizational scheme for the first three sessions of the conference grew out of a "wave" metaphor corresponding especially to access-to-justice developments in the United States. ${ }^{12}$ The first wave, beginning in 1965 with the Office of Economic Opportunity's neighborhood law firm program, involved the reform of institutions for delivering legal services to the poor. The second wave sought to extend representation to "diffuse interests" such as those of consumers and environmentalists; it commenced in the United States with the development of foundation-supported "public interest law firms" in 1970. The third wave followed in the 1970's with a shift in focus to dispute-processing institutions in general, rather than simply on institutions of legal representation; less formal alternatives to courts and court procedures have emerged in bold relief as part of this new reform trend.

The first question, raised explicitly by Professor Erhard Blankenburg of Berlin and Amsterdam in his paper for the conference, is whether this three-wave scheme corresponds to the situation on the European Continent. The Federal Republic of Germany, he argued, is barely into the first wave, with a few minor reforms of its over fifty-year-old system of legal aid by private lawyers compensated by

11 See, e.g., the forewords to each of the four volumes, Access to Justice, Volumes I-IV; Cappelletti \& Garth, Access to Justice: The Worldwide Movement to Make Rights Effective: A General Report, in Access to Justice, Volume I, at 3.

12 See. Cappelletti \& Garth, supra note 11. 
the government - the "judicare" system. "Public interest law" is absent, and, moreover, the courts operate differently than in common law countries like the United States. In addition, the legal profession in the United States is unique with its remarkable involvement in social policy formulation through legislative and administrative lobbying, test cases, and class actions. And, finally, lawyers and litigation are of lesser political importance in countries like Germany where there is a strong political party system and where, therefore, there always is one more or less ideological party seeking to represent the interests of the working class, the poor, and other similar groups of potential voters. In these countries, change is less likely to be sought through the efforts of ad hoc interest groups and court litigation. To a certain extent, then, America is sui generis; one cannot easily equate developments there with those in the Federal Republic of Germany of perhaps elsewhere in civil law jurisdictions.

Our response, however, is that the basic forces that have generated American developments have also been important throughout Western Europe. Of course, there are profound differences, but a common trend is still evident. In welfare states generally, rights on behalf of disadvantaged or unorganized groups such as the poor, consumers, and the like have proliferated recently, concern has arisen about the effectiveness and enforcement of those rights, and the political and constitutional principle of equality has been applied in order to enhance access to courts and to other dispute-processing machinery. While, admittedly, a simple chronology based on the United States could be misleading, and while we should not expect precisely the same developments in all welfare states, we believe that the analysis underlying the wave metaphor is nevertheless valid. As will be explained below, it can be used to examine the implications of this trend even in countries where the chronology, extent, and methods of developments appear very different than in the United States.

A second and related problem is what the wave metaphor as a sequence implies for the first two waves. Are these to be replaced by a third and new approach? Assistant Attorney General Maurice Rosenberg suggested that the three waves could each be viewed as "sound waves" continuing to radiate out into further reform. Others, such as Professor Charles Halpern, expressed the fear that informal alternatives to the courts could be designed to replace legal aid and public interest law reforms. Our view is that the third phase in the access-to-justice movement should be seen as an absorption, 
not a replacement, of the first two. The three should embody a coherent effort to enforce and expand the new rights that now belong to the underprivileged sectors of society - the poor, tenants, consumers, environmentalists, employees. If the third wave were to consist only of informal procedures and institutions designed to replace legal aid and public interest law, then that coherent effort would be missing. The conference's organizational scheme, as will be noted again in discussion of the third session, does not mean to imply the demise of developments in waves one and two.

A further potential problem transcending the organization of the conference concerns the issue of "transplantation." The differences between the United States and, say, the Federal Republic of Germany can again be raised, this time to question the utility of juxtaposing American and German (or other European) approaches if the aim is to develop practical, effective reforms. Commentators at the conference repeatedly and quite justifiedly stressed how difficult it is to take an institution from one legal culture and transplant it successfully in another. Nevertheless, successful transplants do occur, sometimes surprising those aware of these difficulties; and this occurrence is most frequent when the transplant is motivated by a social, economic, or political "need" shared in common by the countries involved. As Professor Takeshi Kojima from Tokyo pointed out, for example, the German Civil Code was adopted for Japan at the turn of the century as an aspect of Japan's need for "modernization"; it is still the basis for Japanese civil law. Within the access-tojustice movement, one can note the proliferation of the ombudsman institution well beyond its Scandinavian roots and the continuing development in Europe, the United States, and elsewhere of the combined judicare-staff system of legal aid described below. Admittedly, as in Japan, the transplanted institution may develop differently in the new country's soil, but the purpose of the transplant may still have been served.

Moreover, the juxtaposition of various methods for attacking similar problems stimulates innovation and further efforts at reform. Thus, while European commentators do not as a rule advocate the adoption of the U.S. class action device, the class action has helped to inspire a number of European reforms and reform proposals. ${ }^{13}$

13 See, e.g., Kötz, Public Interest Litigation: A Comparative Survey, infra at 85, 104-108; Rehbinder, Controlling the Environmental Enforcement Deficit: West Germany, 24 AmErican JOURnal of Comparative LAW 373 (1976). 
American scholars and policy-makers, on the other hand, although they typically show little eagerness to learn from developments elsewhere, ${ }^{14}$ can especially profit from a familiarity with the situation in Europe. ${ }^{15}$ The difficulty of transplantation is no excuse for avoiding serious comparative study.

\section{Session One. Legal Aid for the Poor}

Legal aid reform continues to occupy a central role in the accessto-justice movement. Just a few days before the Florence Conference, for example, the European Court of Human Rights in Strasbourg reaffirmed the constitutional importance of legal aid as a means to enforce a right of effective access. The Airey decision 16 held that Ireland violated the European Convention for the Protection of Human Rights by failing to provide Mrs. Airey with legal aid to obtain a legal separation from her husband. The Senator from Ireland, Mr. David Molony, stated at the conference that this decision will provide impetus for long overdue legal aid reforms in his country.

In analyzing legal aid developments, the familiar contrast between European "judicare" systems, such as those in England, France, and Germany, and "salaried staff attorney" systems, such as those in the United States, ${ }^{17}$ continues to have some validity. Recent French and German developments, described at the conference by Messrs. JeanPierre Plantard and Paul Schuster of the French and German Ministries of Justice, tend thus to focus mainly on improving the legal advice potential of judicare. Beyond such reforms, however, there is a growing recognition that the virtues of judicare and staff

\footnotetext{
${ }^{14}$ See Stein, Uses, Misuses - and Nonuses of Comparative Law, 72 Northwestern LAw REVIEW 198 (1977).

15 For example, it is striking that the debates in the U. S. House of Representatives about the Dispute Resolution Act, when proposed in 1978, made almost no reference to experiences outside the United States (except for two articles appended to the published Hearings). Indeed, there is an almost amusing exchange during the debates about what exactly the situation is in England with respect to institutions like neighborhood justice centers. See HEARINGs BEfore the Subcommittee on Courts, Civil Liberties, and the Administration of JusTice of the Committee on the Judiciary, House of Representatives, 95TH Congress, 2D Session on S. 957, Dispute Resolution Act, July 7, August 2, 1978 (Committee Print, 1978).

${ }_{16}$ European Court of Human Rights, Judgment of October 9, 1979, Airey; see also Judgment of May 13, 1980, Artico.

17 On this contrast, see, e. g., M. Cappelletti, G. Gordley \& E. Johnson, JR., supra note 5 , at 271-523.
} 
systems should be combined in a "mixed system" of delivery. Movements toward this combination began in the early 1970's in Sweden and in the Canadian provinces of Quebec and Manitoba. ${ }^{18}$ Professor Fred Zemans from Toronto and the Swedish Chancellor of Justice Ingvar Gullnäs noted the important successes of these relatively early and at that time isolated innovations, and a recent trend toward a combined model of legal aid was reported by commentators from Holland, Norway, Great Britain, and the United States. The situation in the latter two countries is explored in the reports by Professors Gary Bellow and Michael Zander. The leading common law models of staff and judicare are finally learning from each other.

A combined system is emerging in Great Britain through the proliferation of "neighbourhood law centres" complementary to the judicare system. Thirty of these centres were created in the last decade, mostly in London, and Professor Zander predicts that the number will expand to one hundred in the 1980's. This prediction was corroborated by the publication, just prior to the Florence conference, of the long-awaited final report of the Royal Commission on Legal Services. ${ }^{19}$ After three years of detailed study, the Commission's emphasis on the need for more law centres, which it preferred to term "citizens' law centres," will probably do much to increase the proportion of funds that go to the "public sector" in British legal services. In the United States, on the other hand, an increased role for judicare is needed to produce a combined system. Some thirty-eight publicly funded experiments with judicare and other alternative programs have just been concluded, and evidently the results, as indicated by Dan Bradley, the newly appointed President of the Legal Services Corporation, will encourage a substantially greater role for judicare in the United States. President Bradley thus echoed Professor Bellow's support for a "much greater involvement of the private bar" in the legal aid system of the United States. ${ }^{20}$ While the Corporation's funds are at present tied mainly to the existing local staff programs, it appears that there will be a great effort in the near future to add a judicare component to the U.S. program.

Evolution in the structure of legal aid systems necessarily will continue, but the movement in the direction of combined systems is

18 See, e.g., id., at 525-619.

19 Royal Commission on Legal Services, Final Report, Cmnd. 7648 (London, H. M. S. O., 1979).

20 Bellow, Legal Services to the Poor: An American Report, infra at 49, 52, 65 n. 41. 
clear and encouraging. It is essential, therefore, to begin to address questions that have surfaced throughout the legal aid movement but have yet to be resolved. The papers in this volume provide insightful discussions of a number of these key issues. While it would not be useful to repeat the points made by Professors Bellow and Zander, a few especially important topics raised at the conference merit attention.

First, the proper balance between judicare and staff systems remains to be determined. At one level is the perplexing question of how much funding to devote to each, which can only be answered by a fair and responsible decision-making body. Perhaps even more problematic is the issue of how work should be divided between staff and judicare - between governmental lawyers and the private profession. Absolute freedom of choice for the client is one possible solution, as suggested at the conference by Professor Bellow and given very strong support by the Chancellor of Justice of Sweden, Mr. Gullnäs; and indeed the situation in Sweden is consistent with that solution. At the other extreme is an enforced division of labor, which Professor Zander supports and which resembles the situation developing in Great Britain. The private profession in Great Britain has primary responsibility for legally aided domestic matters and criminal defense. This division cuts down on freedom of choice, but it frees the salaried lawyers to concentrate more on enforcing the "new rights" of tenants, consumers, welfare recipients and the like, and on other tactics such as community education, work with community groups, and test case litigation. In Sweden, in contrast, staff lawyers handle numerous domestic relations matters. Obviously, the correct division of labor depends on a number of factors, including how many lawyers are available and the social role envisioned for the staff lawyers, but one must recognize that there are other values besides freedom of choice. In many places it may be necessary to the effectiveness of staff lawyers to channel certain types of cases to the private bar.

A related question of balance concerns the type of advocacy to be pursued by the staff or neighborhood offices. Professor Zander recommends that the English law centres emphasize (as in fact they do) "work for communities and groups, since this is work that is virtually not done by private practitioners at all." ${ }^{21}$ Professor Bellow has taken a very similar position in his paper and in his own legal

21 Zander, The First Wave, infra at 27, 41. 
services work. This emphasis on building and serving organizations for the poor obviously increases the need for subsidized private practitioners who will handle the bulk of individual cases. Further, this emphasis points beyond the combined staff-judicare model to another type of combination. A key ingredient of this new combination is what Professor Bellow describes as "efforts to decrease the centrality of lawyers - or, at least, lawyers playing traditional roles in the legal aid system." 22 Staff offices can help create and monitor dispute-processing fora responsive to unrepresented persons or to persons represented by lay advocates. Alternatives to the courts, discussed also in the third conference session, can in this manner not only be made useful to individuals to enforce their new rights, but also they can free staff offices from some of the overwhelming burden of individual cases. Those offices can then concentrate their energies on potentially more effective activities such as group and test case advocacy. This reform scheme, as stated, oversimplifies the problem somewhat, but it shows how one vision of advocacy in the "first wave" may dictate certain types of reforms seen as part of the "third wave," discussed below.

Reflections on the types of advocacy appropriate for the first wave lead to other unresolved problems raised in the papers. Among these problems are: 1) how much participation the client population should have in the control of legal aid programs and in the setting of program priorities; and 2) how to ensure that legal aid advocacy is of a sufficiently high quality. Both these problems ultimately are ones of accountability, but the best means for assuring accountability have yet to be found. Local control by professionally dominated governing boards in the United States, as both Professor Bellow and President Bradley observed, has not resulted in the uniform maintenance of high professional standards. And while the English law centres believe very strongly in the success of their lay-controlled management committees, fear that such committees are inadequate probably is what led the Royal Commission on Legal Services to suggest that only "advisory committees" be constituted for law centres. ${ }^{23}$ Local control by the supposed beneficiaries of legal services, however, is a very attractive idea, and hopefully methods can be found to preserve quality while continuing to encourage the trend towards lay partici-

22 Bellow, supra note 20, at 67.

23 Royal Commission on Legal Services, supra note 19 , at 84. 
pation. Professor Bellow's paper describes at least one possible way to improve quality. The Legal Services Institute in Boston, which he and Jean Kettleson established and which the Legal Services Corporation has funded, is attempting to develop new and effective methods of advocacy training, and the results obtained by the Institute will undoubtedly be of great interest both inside and outside the United States. It may provide a vital means to bolster the quality of advocacy without being inconsistent with strong local, especially lay, participation in legal services programs. The difficult issues have yet to be resolved, but at least the fundamental issues in legal services are now being addressed.

\section{Session Two. The Protection of Diffuse and Frag- MENTED INTERESTS}

In both North America and Europe there has been tremendous activity in recent years aimed at providing mechanisms, both governmental and private, to protect the diffuse interests of consumers, environmentalists, and other traditionally unrepresented or underrepresented groups. Efforts to represent group interests of poor people belong in the same category. In addition to the innovations described by Hein Kötz and by David and Louise Trubek in their papers for this session, conference participants such as Gordon Borrie, the British Director-General of Fair Trading, and Niels Ehrenreich, the Consumer Ombudsman of Denmark, reported on their respective institutions, and Brendan Byrne, the Governor of the State of New Jersey, explained the workings of the Office of the Public Advocate, which his administration pioneered. While American-style class actions and public interest law firms do not exist in Europe, other methods such as consumer group actions in France and Germany serve similar purposes and reflect the same trend. ${ }^{24}$ As Professor Kötz suggests in his paper, the second wave implies a new kind of litigation to answer new social needs, and comparative study reveals that this is not an "isolated phenomenon," but "part of a more general worldwide development." 25

Conference participants raised a number of difficult questions

${ }^{24}$ See, e.g., Fisch, European Analogues to Class Actions, 27 American Journal of Comparative Law 51 (1979).

25 Kötz, supra note 13 , at 116. 
about the meaning, potential, and even the legitimacy of this worldwide development. There was ample discussion, in particular, about the trend to create new, specialized governmental agencies to protect diffuse interests, about the success of such agencies, and about their being "captured" or "over-bureaucratized." Also discussed was the question whether individual and/or organizational "private attorneys general" should be allowed to play a role in lieu of, or in addition to, such governmental advocates. One question which was addressed at the outset was the propriety of governmental encouragement and subsidization of what can certainly be seen as "political" activity - extending and enforcing rights on behalf of certain sectors of the population. Some essentially nonpolitical answers to this question can be taken from the papers for this session. First, there are "defects" in pluralism that lead to "underrepresentation" of certain types of groups, and governmental action to correct that imbalance can be seen as necessary to achieve fair and correct decision-making. A problem, however, as Professor Martin Shapiro noted in his paper for the fourth session and in his comments at the conference, is that despite the seemingly neutral justification for governmental intervention, "[e]veryone in the game knows we are talking about access to political power." 26 Conference participants active in legal services and public interest law agreed that much of their work was inspired not by procedural concerns for access and fairness, but by a substantive desire to help the poor and other disadvantaged groups. That substantive desire may be consistent with some political consensus within the welfare state, and it may as a practical matter lead to procedural fairness, but it also raises issues that blur any neat distinction between law and politics. This question of general political legitimacy cannot be avoided.

Beyond the general concern with legitimacy, however, is the more specific question of the role of the courts in extending rights, making policy decisions, and seeking to enforce social change that may not be obtainable through legislative action. This question has long been debated in the United States, and it has particular relevance there, but courts have assumed more power recently in European countries as well. Professor Roger Perrot of Paris, for example, wrote in 1977 that the most important problem for French judges

26 Shapiro, Access to the Legal System and the Modern Welfare State: American Continuities, infra at 273, 292. 
was "l'immixtion du juge dans la fonction législative." ${ }^{27}$ Not only is it difficult for judges to fulfill legislative roles - an observation given substance at the conference by the Chief Justice of the Supreme Court of Florida, Arthur England - but also it places new burdens on the courts and may appear contrary to democratic theory.

One response to this problem, made at the conference by one of the present writers, is that the enormous growth in recent decades of the executive and legislative branches of government makes necessary a corresponding growth of the judicial branch. Checks and balances require the judicial branch to have enough power to carry out in modern circumstances its traditional role of defender of liberty. Mega-legislation and mega-administration - two typical and, perhaps, inevitable features of modern societies - demand megaadjudication to control those two. And this phenomenon is far from being limited to the United States. In Continental Europe, first the special administrative courts and more recently the constitutional courts were created to do what the ordinary - career and too rigidly rule-bound - judiciary was not seen as able to do: to undertake the tremendous responsibility of controlling the growing power and jurisdiction of the political branches.

Professor Lawrence Friedman, in addition, insisted that courts are not usurping this new power. Often such a power has simply been given to them through executive and legislative action, and where that has not been the case, the explanation for activism is still not uncontrolled judicial "imperialism." Judicial activity takes place as part of a complex governmental process, and it cannot long continue in one direction or another in the face of widespread disapproval by other policy-makers. Intentionally vague statutory language, coupled with acquiescence in judicial interpretations, characterizes much of so-called judicial law-making. Whether we like or dislike the increased judicial role, it is clear that such a role does exist, especially for the protection of diffuse and fragmented interests, and that it reflects a certain governmental consensus. It is no more or less democratic than other governmental activity.

This court role in the welfare state may be a legitimate one, but further questions arise about how much it actually can accomplish on behalf of diffuse interests. The Trubeks in particular raise these issues in their paper. They suggest that the second wave may be re$91,94$.

27 Perrot, Le rôle du juge dans la société moderne, 1977 GazzetTe du Palais, Doctrine 
ceding in the United States because foundations will no longer provide support for new public interest law firms, but they see this as an opportunity to overcome the limitations of an excessive reliance on lawyers and lawsuits. They hope for a resurgence based on a more effective approach to the representation of diffuse interests, and they see some trends in the United States that may provide grounds for optimism. Their principal and more general theme, however, is the necessity of rethinking in the United States and elsewhere our procedures for enforcing consumer and similar rights. They argue that the effective enforcement of consumer rights requires the careful linking of professional advocates such as those in public interest law firms, private interest groups, interest group representatives who participate directly in governmental or business decisions, governmental advocates, and private individual advocates. A coordinated and concentrated effort must be made.

Significantly, this kind of approach, which at bottom seeks to build constituencies by informing and strengthening private interest groups, relates very closely to that "combined system" supported for the rights of the poor by Professors Bellow and Zander. In addition, Phil Leask, Secretary of the Law Centres Federation in Great Britain, directed his commentary to this point. Law centres, he suggested, are trying to implement a strategy much like that supported in the Trubeks' paper. There are some problems inherent in that approach, especially the "political" problem discussed above, but the emerging consensus among access reformers seems to be that such an approach is necessary if the rights of diffuse interests, including the poor, are to be adequately advocated and enforced.

\section{Session Three. Beyond Legal Representation: Dispute Processing and Non-Judicial Alternatives}

Recently, the focus has tended to shift away from organization and aggregation of interests and their representation in court, turning toward individual disputes and alternatives to the courts and court procedures. That shift, however, is perhaps misleading. The "third wave" analyzed by the Florence Project has not been limited to the proliferation of non-judicial dispute-processing alternatives. It implied a willingness to go beyond institutions of legal representation, but not necessarily to replace them. ${ }^{28}$ Nevertheless, so much reform

28 See, e. g., Cappelletti \& Garth, supra note 11, at 49-54, 95-99, 111-18. 
activity outside the normal courts has recently taken place that it is useful to limit discussion here to the scope and implications of this striking new development.

Some recent manifestations of non-judicial alternatives were discussed at the conference by persons directly involved in their operation. Mr. Pierre Bellet, the Premier Président of the French Cour de Cassation, described the new institution of the French conciliateurs, local individuals appointed by the relevant court of appeal to seek to bring disputants to an amicable agreement. Mr. Nils Mangård, the Chairman of the National Consumer Complaints Board of Sweden, reported on this innovative institution. Mr. Gordon Borrie, the British Director-General of Fair Trading, discussed how his office has contributed to the development of new consumer complaint arbitration schemes. And Mr. Hans-Peter Furrer, the Head of Division I of the Directorate of Legal Affairs for the Council of Europe, provided an extensive discussion of the valuable work of the Council of Europe in the encouragement of not only legal aid reforms but also the special procedures that will facilitate access to justice. ${ }^{29}$ Indeed, as Mr. Furrer pointed out, the Airey case described above ${ }^{30}$ may give further impetus to a trend toward less formal court procedures or alternatives to the courts. The European Court of Human Rights specifically held that Ireland could have satisfied the right of access either by the extension of legal aid or by simplification of the procedures required for a matrimonial separation.

Perhaps the greatest surge of enthusiasm for non-judicial alternatives, however, has been in the United States. The three experimental Neighborhood Justice Centers recently funded by the U.S. Department of Justice have received considerable attention, and Ms. Linda Singer, Director of the Center for Community Justice, and Professor Frank Sander provided some insights as to how they have been working in practice. Mr. Sanford Jaffe, Officer in Charge of the Ford Foundation's Government and Law programs, detailed the Foundation's major role and recent initiatives in leading away from an exclusive focus on legal representation in court. ${ }^{31}$ Given the crucial significance that the Ford Foundation had in the legal services

29 See H.-P. Furrer, The Council of Europe Programme (unpublished paper circulated at the Florence Conference, October 15-18, 1979).

30 See text at note 16 , supra.

31 See also Ford Foundation, New Approaches to Conflict Resolution (N. Y., Ford Foundation, 1978) (prepared by Mr. Jaffe). 
and public interest movements, these recent initiatives can be expected to have a powerful influence in the United States. Mediation as an alternative to litigation has assumed considerable importance in recent U.S. reforms and experiments, both at the local level through community courts or Neighborhood Justice Centers and with respect to diffuse interests through such devices as "environmental mediation." 32 Professor Maurice Rosenberg, now presiding over the U. S. Justice Department's Office for Improvements in the Administration of Justice, suggested at the conference that different dispute-processing fora should be created for different types of disputes. Professor Earl Johnson's paper for this session also pointed to the support in the United States for a much greater pluralism in dispute-processing.

The analyses in the papers for this session, however, do not simply call for informal tribunals or other institutions that presumably are shaped to fit the dispute. One problem, mentioned by Minister Robert Krieps, Governor Brendan Byrne and several other conference participants, is that the urge to by-pass the courts may relate in part to the inadequacies of civil procedure, especially in the United States. Professors Blankenburg and Kötz emphasized this comparative point. With respect to the third wave, both asserted that the regular courts in at least the Federal Republic of Germany, unlike those in the United States, already have many of the characteristics sought by those seeking non-judicial alternatives in common law countries. The regular German courts (and even more so the many special courts for social and labor matters, where lay participation in the adjudicatory process is also very large) are relatively informal, have very active judges, and are designed to encourage mediated settlements through judicial intervention. This observation no doubt has validity as a general rule, but it is not clear what it implies for the access-to-justice movement.

First, it is interesting that the German reforms in civil procedure which created this situation (as well as the reforms which created the German judicare system, a system that preceded similar developments elsewhere in Europe) were, like many modern access reforms, connected to what can be seen as welfare state developments. Indeed, as stated by Advocate General Ernest Krings, improved access

32 See, e. g., G. Cormick, Resolving Environmental Conflicts through Mediation: Experience, Process and Potentials (unpublished paper presented to the American Sociological Association Annual Meeting, San Francisco, Sept. 7, 1978). 
to law and justice is always an essential part of what is called the welfare state. The Social-Democratic government of Weimar Germany, which in many respects anticipated later welfare state activities, ${ }^{33}$ enacted these reforms in the early 1920 's. ${ }^{34}$ It is not surprising, therefore, that Germany already has some of the institutional forms that are now being sought elsewhere. In this sense, Germany has been a participant in the access-to-justice movement even before other countries in the West.

Further, one cannot say in any event that problems of access have been overcome in Germany or, for that matter, elsewhere in Europe. Very recently, for example, a new system of family courts came into effect in Germany. ${ }^{35}$ Beyond such examples of new reforms, in addition, Mr. Ludwig Krämer, formerly a German judge and now an officer of the Commission of the European Communities, spoke forcefully about problems in access that continue to plague Europe. He stated that nowhere in the Community do consumers have practical access to institutions that will enforce their rights effectively.

It is well to recognize that access problems may differ in degree in different legal cultures, or that they now face a different institutional setting in countries like the Federal Republic of Germany. It may be, as Blankenburg states in his paper, that certain Americastyle reforms are unnecessary or unworkable in, say, Germany. Nevertheless, it remains true that access-to-justice reforms are required, and that the welfare state ideology tends to channel those reforms in similar directions in countries with similar economic and political systems. As emphasized by Minister Ivo Samkalden, by Professor Halpern and others, increasingly certain basic problems are similar in various countries; they involve people as "world citizens" rather than merely as the citizens of one nation.

These comparative observations again underline the difficulty of transplanting from one country to another. Professor Marc Galanter's paper for this session further emphasizes the complexities of institutional reform. Dispute-processing institutions, he explains, do more than resolve disputes. They send messages that blend with

33 See, e.g., R. Unger, Law in Modern Society (N. Y., Free Press, 1976).

${ }^{34}$ See the discussion in Millar, The Recent Reforms in German Civil Procedure, 10 AMERICAN Bar Association Journal 703 (1924).

35 See Bender \& Strecker, Access to Justice in the Federal Republic of Germany, in Access TO Justice, Volume I, at $527,541$. 
"indigenous law" - i.e., general local community notions of fairness - to produce regulatory outcomes that may or may not be consistent with "official law." While reform cannot await perfect knowledge of potential impacts, more attention in research must be paid to the phenomena described by Galanter. A sensitivity to those issues, combined where possible with adequate experimentation, is necessary to avoid implementing reforms that have little chance of achieving the desired results.

It surely is not simple to design and implement reforms perfectly consistent with the goal of effective access to justice, yet reforms tending toward such a goal are necessary. A principal virtue of Professor Johnson's paper for this session is that it illustrates brilliantly and effectively the need for reform and some potential consequences of reaction and retreat. Among the alternative futures imagined by Professor Johnson is a "fourth scenario" of "lowered expectations," characterized by noxious air pollution and tremendous social inequalities. The more pluralistic and access-oriented "scenarios" depicted in his paper certainly provide a more desirable vision of the future, even though such a future dispute-processing system, while no doubt possible, is still a long way from our present situation.

Several commentators at the conference suggested other possibilities, related to but different from Professor Johnson's proposed scenarios. Even a trend toward the creation of "accessible," informal alternatives to the existing courts may have the potential to contribute toward a society of lowered expectations and increased social inequalities. Disputes, even small ones, do not necessarily involve two persons alone. They might involve issues of larger societal concern - for instance, defects of a given type of product. It may be dangerous, therefore, to divert such cases to "low visibility" informal alternatives. To be sure, as stressed by Senator Molony and Professor Jan Hellner, alternatives - even informal ones - do not necessarily imply low visibility and lack of societal impact. As a matter of fact, visibility and impact may be very great with such alternative devices as consumer ombudsmen, especially if they can establish a good alliance with the mass media. Also, devices involving community participation of some appropriate kind may have both high visibility and the capacity to "radiate social benefits" - often intangible ones - much beyond the particular case. Nevertheless, one must guard against informalism used to mask social problems and prevent their just resolution. 
Informality may have other problems. As pointed out by Professor Bellow, informality may express itself differently vis-à-vis different social categories. It may result in lack of courtesy, bruskness, and unfairness toward the culturally and socially disadvantaged parties. Any realistic discussion about alternatives, then, should take into account the "stratification" of society - and the stratification of the legal profession as well. Appropriate training and selection are essential not only for ordinary court personnel, but also for the personnel of informal "alternative devices."

The problem of coercion also emerged within the context of the discussion on informal alternatives. It was stressed by several participants, including Attorney General Criton Tornaritis, Senator Molony, and Messrs. Furrer, Krämer, and Schuster, that modern constitutions as well as the European Convention of Human Rights guarantee a fundamental right to the "natural judge," $i . e$., a right to bring one's grievances in court. People expect to have "justice" and might feel coerced if compulsorily sent to alternative fora. It was answered by Assistant Attorney General Rosenberg and others, however, that this does not usually prevent the possibility of diversion, even compulsory, from court to an alternative tribunal provided that the diversion is only temporary and the party is given the possibility to "return to court without penalty." It was also observed by Professor André Tunc and one of the present writers that too much "constitutional guarantism," if rigidly applied, might end up with "Rolls-Royce justice" and a de facto exclusion of the bulk of the population from effective access; and that alternative fora, if properly designed, operated by properly selected and trained personnel, and used for the proper kind of disputes, may offer not only cheaper, quicker, and more effective "justice," but also justice which is, and is seen to be, more "just," i. e., of a higher quality.

Finally, it was pointed out by Linda Singer and others that the mediation of disputes - for instance, environmental disputes - can work successfully and fairly only where the parties have comparable bargaining power or there is a credible lawsuit threat underlying positions taken during mediation hearings or negotiation. ${ }^{36}$ If the environmentalists have no credible remedy, it is much less likely that mediation would help promote environmental protection. In other words, courts and judicial remedies provide a background of norms

36 See G. Cormick, supra note 32 , at 17. 
and procedures - a "bargaining endowment," as Galanter put it against which negotiations and mediations can effectively take place. Thus, as suggested by Professor Halpern, only the existence and success of first and second wave reforms can make possible an effective mediation approach in situations involving disparities in power and resources. If, however, mediation is seen only as a replacement of other reforms, we are faced with a very different "scenario."

Professor Harry Street in his paper confirms this danger based on his long experience as a judge in British administrative tribunals. He states that what we find "all too often is the surrender of the individual to a compromise which perhaps in justice he should not have accepted." 37 Conciliation or mediation of welfare state rights and interests may inhibit their enforcement in the absence of means to overcome disparities in bargaining power. If the welfare state is to become a reality for its intended beneficiaries, bargained or mediated outcomes must be made consistent with rights enforcement.

\section{Session Four. Access to the Legal System and the Mod- ern Welfare State}

Many reforms consistent with the access-to-justice movement can be seen as minor technical improvements in the machinery of justice. Many others represent simple cost saving devices or means to cut down court congestion. Reforms that enhance "access" can be inspired by varying political philosophies, from the most conservative to the most radical. Yet the access reforms with which the Florence Project has been concerned - reforms that have become typical in a growing number of Western countries in recent decades - are related very closely to what is usually called the welfare state. This term implies a society with considerable governmental involvement in an essentially private economy and with a governmental commitment to ameliorating the economic and social conditions of the disadvantaged - the poor, certain minorities, tenants, employees, and, increasingly, other diffuse interests such as that of consumers.

Social programs to benefit disadvantaged groups and interests have been enacted, and a wide variety of legislation and regulation purports to improve the position of the disadvantaged in relation to

37 Street, Access to Justice and the Modern Welfare State: A European Report from the Standpoint of an Administrative Lawyer, infra at 295, 310. 
large businesses and governmental agencies. The tremendous proliferation of legislation and regulation favoring the relatively weak is a defining attribute of the welfare state. For the welfare state to mean more than an array of new law, however - for it to exist as the type of society embodied in those laws - requires that the laws be enforced, and this requirement necessarily points us to problems of access. A merely formal right of access is not adequate to mobilize the disadvantaged to implement these new laws. Effective access requires a serious social effort - affirmative and enduring action by the state.

While it is clear, as Professor Lawrence Friedman observes in his paper, that new social forces have been behind the extension of rights in the welfare state, whether through legislation, regulation, or adjudication, it is not so clear that those forces are capable of getting the rights enforced as a practical matter. Reforms generally may result from a number of interest group mixtures, and what is enough for getting a new law enacted may not do for enforcement. One should not discount the actual and potential role of legal professionals in enhancing the power of certain disadvantaged groups to go beyond mere declarations of rights. For example, legal researchers have tended to discover "gaps" in the enforcement of new rights, many lawyers have been inspired by the desire to take seriously the values inherent in our systems of justice, and other members of the profession, perhaps seeing themselves as custodians of the legal system, have had their own incentives to adjust procedures and institutions to the new demands being made. To be sure, many segments of the legal professions have resisted the pressure for change, but in the United States and Europe much change is nevertheless taking place. Both the number and the diversification of lawyers and adjudicators are increasing, and these professionals are becoming more and more involved with the legal and social issues generated in the welfare state. As this conference session showed, the legal professions must now consider not only the importance of access, but also the problems and prospects of the welfare state.

Professor Harry Street in his paper notes several of these critical problems. He explains, for example, that "The United Kingdom is paying the price for an unrestricted right of the public to participate in the inquiry [regarding land control and expropriation]." 38 Too much access may cripple government. Professor Friedman notes the

38 Id. at 299. 
analogous dilemma of judicial review when it deals not with "real," but with "phony" issues raised by parties trying to stop or delay governmental action that they oppose. ${ }^{39}$ Similar problems are raised also in Professor André Tunc's paper and came up in discussion at the conference, initiated by Professor Martin Shapiro, on the difficult question of costs. To a certain extent the high costs of traditional litigation may increase the momentum for access-oriented reform, but ultimately we face the issue, noted at the beginning of this Introduction, of how many resources should be devoted to enhancing access to justice for certain groups and interests.

That difficult question is complicated by an even more fundamental one. The result of enhanced access for claimants and defendants asserting what we have termed the "new rights" would be a notable extension of the welfare state. Mr. Max Kohnstamm, the Principal of the European University Institute, Professor Sir Andrew Shonfield, the Head of the Economics Department of the Institute, and several other commentators emphasized at the conference that increased expenditures on access inevitably will lengthen the reach of the "Leviathan" state. More regulations will be enforced, more bureaucracies may be created, and arguably private enterprise will be shackled further by the need to conform to numerous complicated laws. This fear may or may not represent the actual and future situation in Western societies, but the fear is certainly a growing one, reflected especially in recent elections in Great Britain and Sweden, and in the current U.S. Presidential campaign. Indeed, this fear threatens not only the access-to-justice movement, but also the entire vision of a welfare state on which that movement has been constructed. In the words of Professor Street, "There is one big enveloping issue: justice in the Welfare State." 40

The reaction to the costs of the welfare state represents a crucial challenge to everyone, including legal professionals. The papers for this session provide important insights into how we might respond to this challenge. Professor Tunc, for example, concludes his paper with six suggestions to facilitate the planning and coordination of regulation. The challenge, of course, is not only to plan and coordinate regulation, but also to devise effective means through which important legislation and regulations will be enforced. There are

39 Friedman, Claims, Disputes, Conflicts and the Modern Welfare State, infra at 251, 264.

40 Street, supra note 37 , at 306 . 
problems with the welfare state, but Professor Tunc admirably states the case for its continuation and elaboration: "Economic regulation is a poor substitute for social ethics; social security, a poor substitute for spontaneous community solidarity. But both are unavoidable for the protection of man in our present societies." 41 The irony is that much of the welfare state is now being questioned in political circles, while at the same time unprecedented efforts are being made to enforce the new rights. Whether or not to encourage that contradictory situation depends, of course, on one's political preferences, but if we favor the new social rights, or more generally the governmental attempt to improve the living conditions of our disadvantaged people through reforms in housing, working conditions, consumer safeguards, and the environment, we must ensure that those new rights will be made effective. Planning for effective enforcement is essential, even if that enforcement may provide further ammunition to the reaction against welfare state costs. There are problems in shaping dispute-processing machinery to fit social policies, and in a certain sense, again as noted at the outset of this Introduction, those problems are inevitable. Given our refusal to part with essential due process guarantees, there is a limit to how much tinkering with the judicial machinery and procedures can be permitted. Nevertheless, there is plenty of room for more creativity and reform.

\section{Prospects for Future Action}

The necessity of future action does not need to be explained. No one at the conference doubted the continuing importance of research, creativity, experimentation, and reform, and hopefully action will be encouraged by the various leading legal policy-makers who assembled in Florence from so many countries of three Continents. While the Florence Access-to-Justice Project represents only a beginning in this field, we believe that its work can stimulate further comparative and interdisciplinary work, help provide an understanding of an important phenomenon, and add impetus and perspective to promote reform efforts. For example, Justice Michael Kirby, the Chairman of the Australian Law Reform Commission, adopting the Florence Project's terminology, wrote recently in a

\footnotetext{
41 Tunc, The Quest for Justice, infra at $315,358$.
} 
Commission document that Australia needed more movement toward reform in the "second wave." 42 And the October 1979 Commonwealth Law Bulletin reports that the Commonwealth Secretariat, having been requested by the Commonwealth Law Ministers to collate information on the subject on a Commonwealth-wide basis, "decided to await publication of [the Access-to-Justice series] before developing its own strategies for the civil procedure area." 43 If this Project helps contribute toward such developments, whether through the published volumes or through the impact of conference participants, that will go far to justify the time and effort that this work has entailed.

In addition to the obvious areas for future research and reform, it may be useful to identify the unique potential for activity within the evolving European Community order. ${ }^{44}$ Another comparative project just commenced and centered in Florence under the direction of one of the present writers is now examining what can be termed the "transnational" dimension of rights in Europe. Without describing the aims of this new project in detail, we can note that it will study, among other things, the development of transnational European rights, transnational litigation, and other means of enforcing new social rights in this European setting. Where useful, comparisons to federalism in the United States will be made, and research into methods of improving access will of course continue. The European legal system will need increasingly to adapt to an economy where consumers, victims of pollution, and others such as migrant workers will need to look for effective redress not only at the national level, but at a European level as well.

42 M. Kirby, Community Legal Education, Preventive legal Aid and Law ReFORM 21 (The Australian Law Reform Commission, Discussion Paper No. 14, June 1979).

435 Commonwealth Law Bulletin 1379, at 1380 (1979).

44 The need to expand the access-to-justice movement at the international and transnational level was emphasized by several conference participants, including Professors René David and Ole Lando as well as Messrs. Hans-Peter Furrer and Paul Leleux of the Council of Europe and the European Community Commission, respectively. Professor Lando, in particular, pointed out that underdeveloped countries having few lawyers and little experience find themselves in a weak bargaining position and have serious access problems anytime they have a dispute with rich countries or large corporations of rich countries, e.g., when they need to "buy technology". He suggested that an international tribunal placed above the countries involved should be created to assure to the parties equal access to the law. Paul Leleux, on the other hand, suggested that diverting disputes from the courts might have a side effect which could be particularly negative in Europe, where so many decisions need to be enforced abroad. Court decisions in many areas are easily enforced abroad, especially within the nine Community member states, but it is not so if decisions are taken out of court. 
PART ONE

LEGAL SERVICES FOR THE POOR

THE FIRST WAVE

IN THE ACCESS-TO-JUSTICE MOVEMENT 
(C) European University Institute.

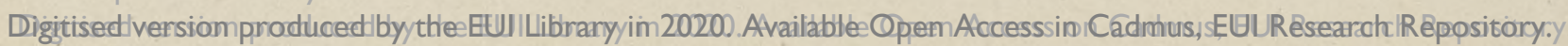




\section{THE FIRST WAVE}

by

MICHAEL ZANDER

Professor of Law, London School of Economics

This paper offers some reflections on the present and likely future state of the art of legal aid (the "First Wave" in the developing Access-to-Justice Movement). It takes as read the very helpful observations on the subject by Mauro Cappelletti and Bryant Garth in their General Report. ${ }^{1}$

The paper does not attempt to analyse the state of legal aid in individual countries. Rather it suggests some common issues and problems that to a greater or lesser extent require consideration in most countries. I have used the English system to illustrate many of the points made, and have referred in particular to the Report of the Royal Commission on Legal Services, which was published a few days before the Florence Colloquium. ${ }^{2}$

\section{The Need for a Legal Aid System Based on Governmental FUNDING}

It requires little argument today that any country that pretends to serious concern with access to justice must establish a system for

1 Cappelletti \& Garth, Access to Justice: the Worldwide Movement to Make Rights Effective: A General Report, in Access to Justice: A World Survey 3 (Alphen aan den Rijn/Milan, Sijthoff and Noordhoff/Giuffrè, Vol. I of the Florence Access-to-Justice Project Series, M. Cappelletti \& B. Garth eds., 1978).

2 Report of the Royal Commission on Legal Services, Vol. I, Cmnd. 7648 (containing the Keport itself) \& Vol. 2, Cmnd. 7648-1 (containing statistical appendices) (1979).

The Commission had 15 members, of which nine, including the chairman, were laymen, and two of the other six were critics of the profession. There were therefore only four orthodox lawyers on the Commission. The terms of reference covered in effect every aspect of the work of the profession including also education and training. 
providing those who cannot afford to pay for lawyers with a form of subsidised legal services paid for out of public moneys. The old notion that the legal profession could be relied on to provide such services as were needed by the poor as a charitable contribution is today wholly discredited. The reality is (and probably always was) that few practitioners are ready to make much in the way of a charitable contribution. Moreover, even the minority who are sincerely willing to provide services to the poor without remuneration could not be expected to do so on any lavish scale. A private practitioner must, perforce, charge for most of the work that he undertakes in order to remain in practice. The voluntary work of private practitioners can, of course, be a most useful supplement to the services provided under the legal aid scheme; they cannot be regarded as an adequate alternative.

\section{No Necessary Incompatability between State Funding and the Continuing Independence of the Legal Profes- SION}

It is clear from the experience of many countries that the argument that state funding spells the end for the independence of the legal profession is not one that can be credibly sustained. The English legal profession is passionately devoted to the ideal of independence. Nevertheless, it has now lived with the judicare legal aid system for over a quarter of a century, and the Bar today receives some 30 per cent of its income from civil and criminal legal aid.

The English legal profession, like that in many other countries, has also accepted the public or salaried sector in legal services as part of the practising profession. Thus, barristers and solicitors who work on salaries in law centres have a right of audience in the courts exactly the same as do private practitioners.

The only significant intervention by the profession in regard to the independence of salaried lawyers has been the requirement of the Law Society that law centres must be "independent" in the sense that the funding authority should not have undue power in the management of the law centre. The conditions for a Law Society waiver from the Practice Rules required by every law centre state that the "management committee must be independent of the funding agency and of central and local government, none of whose representatives 
should be ex-officio Chairman, Vice-Chairman or Secretary of the management committee". There has been no suggestion from the Law Society that the mere fact of state funding in itself compromises the independence of the lawyers working in law centres.

If independence in this context means the capacity of the lawyer to do his full duty for his client without fear of consequences to himself, there is clear evidence from various countries (including the U. S., Australia and England) that even lawyers who are paid salaries out of public funds can be as independent as private practitioners. ${ }^{3}$

\section{Mixed Delivery Systems are Likely to Be Best}

In my judgment there is no doubt that the ideal is to have a legal aid system based on a combination of private practitioners (judicare) and salaried lawyers (staff model). Each has its strengths. The chief virtues of the judicare system are, perhaps, the following:

1) Private practitioners have skills which can be deployed to the advantage of poor clients - providing they are paid for the work. Thus, in England, private practitioners handle a mass of work for the poor in the fields of matrimonial work, criminal and personal injury cases. Private practitioners are geared up to do these categories of work for paying clients, and it seems sensible to utilise their services for poor clients as well. The argument that the poor are unwilling to go to private practitioners is simply not confirmed by the facts. In England the poor use private practitioners massively in these types of cases. ${ }^{4}$

2) Private practitioners exist throughout most parts of the country, and since most firms undertake legal aid work, this is an efficient method of making their services available. Since clients do not want to travel large distances to get the help of lawyers, they are helped if local practitioners can provide at least some of the basic legal services. The alternative is to establish a network of staff offices in sufficient numbers to match the availability of private firms. This

\footnotetext{
${ }^{3}$ For a further discussion see Zander, Independence of the Legal Profession - What Does It Mean?, 73 Law Society's Gazette 758 (September 22, 1976).

${ }^{4}$ Gross public expenditure for legal aid in England and Wales in 1977-1978 was £96.6 million, divided as follows: civil legal aid, $£ 38.4$ million; legal advice and assistance, $£ 6.4$ million; legal aid in magistrates' courts, $£ 20.9$ million; legal aid in crown courts and above, $£ 23.6$ million; Law Society's administration costs, £7.3 million.
} 
is not likely to be practicable, and if it were practicable, it would be hugely expensive.

3) Providing the work is adequately remunerated, the judicare system can make available to the poor the services of experienced lawyers. In England, for instance, a defendant in a criminal case can, through the legal aid scheme, get the services of even the leaders of the profession. Queen's Counsel who undertake criminal work earn a substantial proportion of their total income from legal aid. 5 The contrast with the staff model is very great - in all countries its personnel consists largely of young and relatively inexperienced lawyers.

But, on the other hand, the private sector has certain disadvantages:

1) There are parts of the country where there is a need for lawyers but none have established offices.

2) Experience suggests that although poor clients may bring in a range of legal problems to private practitioners, there are other kinds of problems which, for one or another reason, they do not. (It is also now appreciated that this is true not only of the poor but of all social and economic groups.) ${ }^{6}$

3) Private practitioners cannot easily adapt themselves to a law reform model of legal services, nor do they find it easy to tackle legal problems for "community interests". They are best with the traditional one-to-one relationship of lawyer and client.

4) Private practitioners are inhibited by their traditional codes of ethics from playing much of a role in community education about legal rights and remedies. It is true that the codes are in the process of evolution to permit institutional and increasingly even individual advertising, but it is unlikely that this will lead to much aggressive "out-reach" by private practitioners.

5 In 1976-1977 Queen's Counsel who practised at the criminal Bar in London on average derived $56.6 \%$ of their gross fees from criminal legal aid work. The equivalent figure for Queen's Counsel practising "on circuit" was 36\%. Bar Council, SuRvey of Income AT THE BAR 1976-7, at Table 18 (London, Inbucon/AIC Management Consultants, Ltd., 1978).

${ }^{6}$ Both the U.S. and the U.K. national studies show that lawyer use is not greatly affected by socio-economic background except in relation to property affairs. See B. Curran, The Legal Needs of the Public: The Final Report of a National Survey 198 (Chicago, American Bar Foundation, 1977); 2 Report of the Royal Commission on Legal Services, supra note 2, at 205. See generally M. Zander, Legal Services for the Community, at Chapter 8 (London, Temple Smith, 1978). 
The public sector is able at least partly to avoid or minimise these problems. In particular:

1) staff offices can be placed where they are needed, and

2) they can undertake a measure of law reform, communityoriented work and community education.

In some countries (notably the U.S.) it has been argued that legal aid should be concentrated wholly or mainly in the public sector. In the writer's view this attitude is based on too doctrinaire an approach.

It is usually founded on a comparison between the quality and cost of public as against private sector legal services, and a conclusion that the public sector is a better vehicle for legal services to the poor. I do not find the demonstration of the alleged superiority (per se) of the public sector convincing - either in regard to quality of the service or its cost. ${ }^{7}$ But even if it could be shown that the public sector were generally superior in terms of the quality of the service and cheaper, it would not follow that legal aid should be wholly or mainly channelled to the public sector. Such a decision could only be justifiable if the marginal differences in quality and cost (or either) were sufficiently great to outweigh the disadvantages of establishing a wholly separate system undertaking the same work as the private profession. It cannot be argued convincingly, for instance, that the private profession does, say, ordinary criminal defences, divorce work and personal injury cases so badly that it makes sense for this reason to provide a separate service in these fields to clients who happen to be poor. Equally, even if it could be shown that per unit of work staff offices were cheaper than private practice, it would not follow that this would justify the enormous expense of establishing staff offices all over the country to handle the general legal problems of the poor. ${ }^{8}$

The burden of this analysis, in other words, is that the private sector should be used wherever possible and that the public sector should be brought into action only for matters where the private sector is for one or another reason inappropriate. It follows that I do not favour the Swedish or Quebec system, where the public and the

\footnotetext{
7 See now to the same effect Legal Services Corporation, The Delweny Systems STUdy 90, 116 (June 1980).

8 For a further discussion see Zander, Judicare or Staff? A British View, 64 AMERICAN Bar Association Journal 1436 (1978).
} 
private sectors are regarded as interchangeable and in competition. This, in my view, is to squander the special features of the public sector whilst wasting its energies on work that could be handled more or less as well and as cheaply by the private sector.

I prefer the English approach, under which the public and private sectors complement each other rather than compete. Under the terms to which they have to agree to get their waiver from the Practice Rules, English law centres agree not to compete with private practitioners in the following terms: ${ }^{9}$

1) Apart from initial advice and assistance, and save in the circumstances mentioned in 2) below, salaried solicitors will not normally act in cases where the professional business of the client involves i) conveyancing; ii) commercial matters; iii) divorce proceedings; iv) probate matters (save for personal applications in small estates); v) personal injury claims where the damages, as initially and approximately quantified exceed scale 2 of the county court costs band [in $1980-£ 500$ ]; or vi) in criminal matters where the accused is aged 21 or over.

\section{2) It is understood that:}

A) there will be exceptional circumstances in which a salaried solicitor may undertake cases falling within the categories mentioned in 1) above, for example: in cases of emergency; where the conduct of the client's case requires his professional business to be conducted by the salaried solicitor; where a solicitor in private practice is not reasonably available or where the confidence of the client would be eroded by referral of the case.

In other words, law centre lawyers agree not to compete for the bulk of the legal aid work from which the profession derives a substantial income. A client who comes in with such a problem must normally be sent to a private practitioner - if there is one reasonably available.

The reasons for this division of work are:

1) It avoids unnecessary duplication of work, e.g., the public sector should mainly do what the private sector cannot handle, thus making best use of scarce public funds.

2) It avoids friction between the public and the private sector.

9 For the background to this agreement see Zander, Waivers - The End of a Long Story?, 127 New Law Journal 1236 (1977); M. Zander, supra note 6, at 88-94. 
If the public sector were able to compete for paying work, there would be likely to be considerable antagonism from the private profession. This would tend to make for bad relations between the two types of lawyers.

3) Law centres can specialise and make a distinct and different contribution from that of private practitioners.

But this leaves open the important question whether law centres should mainly undertake work for individual clients in categories of work that do not reach private practitioners ("casework") or should instead try to devote themselves more to group- or communityoriented work and law reform. English law centres, for instance, have not undertaken much "law reform" in the classic American sense, but they have increasingly tended to move into group work. The evidence of the Law Centres Working Group to the Royal Commission on Legal Services stated that it felt this to be the main future function of law centres. In its Report the Royal Commission appeared to be somewhat ambivalent on this issue. It disapproved activist campaigning by law centres to improve social conditions, but it seemed to support the attention given by law centres to groups. ("The existing law centres provide legal advice and assistance to groups and attach considerable importance to this aspect of their work. We agree that such services are important". ${ }^{10}$ ) On the other hand, if law centres are not handling the legal problems that have not previously reached private practitioners, who is to handle them? Can ways be found of getting clients to take these problems to private practitioners? If not, can alternative resources be developed to deal with these individual problems - or must this remain an area of unmet need? There are at present no clear answers to these questions.

\section{ChOICE OF LAWYeR}

In some legal aid systems the lawyer is assigned from a list by the court or by the legal aid authorities. In others, the client is free to select any lawyer who undertakes legal aid work and is 8.21 .

101 Report of the Royal Commission on Legal Services, supra note 2, at 84, para. 
willing to receive instructions in the case. Freedom of choice of lawyer is, of course, preferable. But if the public sector in legal services is prohibited from undertaking certain categories of legal work (as recommended above), this effectively limits freedom of choice of the lawyer. The English client, for instance, who wishes to have his divorce or criminal defence handled by the local law centre will be told that he must instead go to a private practitioner. Is this objectionable? On balance I would argue that the demarcation of function between the private and the public sectors in legal services is the more important of the two conflicting values, justifying this limited restriction on the client's freedom of choice. The client still retains his freedom to select any private practitioner, to the extent permitted by the system in question.

\section{The Desiderata for a Legal Aid Scheme}

If it is accepted that there should be a legal aid scheme and that it should consist of both a private and a public sector, there would seem to be a variety of objectives towards which one should aim:

\section{A. The Widest Coverage for the Scheme}

The legal aid scheme should cover civil and criminal cases, and legal advice and assistance short of court proceedings. The English legal aid system, which meets this test, does not cover defamation proceedings or proceedings before tribunals. (The Lord Chancellor's Legal Aid Advisory Committee has, however, recommended that both these categories of excluded work should be brought within the scheme as soon as economic conditions permit, ${ }^{11}$ and the Royal Commission Report endorsed this proposal. ${ }^{12}$ )

Providing broad cover in theory is, however, not the full story. Legal aid in criminal cases in England has been available for fifty years where the interests of justice required it. In 1963 only half of those tried in the higher criminal courts were granted legal aid; now

11 Lord Chancellor's Office, 25th Legal Aid Annual Report 1974-75, at 44-46, 58-62 (London, H.M.S.O., 1975).

121 Report of the Royal Commission on Legal Services, supra note 2, at 151. 
it is close to 100 per cent; legal aid for trials in magistrates' courts went from some 16,000 in 1963 to over a quarter of a million in 1978. What changed was not the statutory formula but the climate of opinion as to the circumstances in which the interests of justice required legal representation.

\section{B. The Merits Test for the Grant of Legal Aid Should Not Be Unduly Stringent}

In most systems, especially those based on the judicare concept, there is some merits test for the grant of legal aid. In the English system the merits test varies depending on the nature of the legal aid. For "advice and assistance" short of proceedings it is simply whether a solicitor regards the matter as one requiring the help of a lawyer. There is no requirement of an initial certificate of authorisation from any legal aid authority, though such a certificate is required for expenditure over a certain amount. For proceedings in criminal cases the test, as has been seen, is whether a grant of legal aid is in the interests of justice. The test is applied by the courts. The Royal Commission in its 1979 report has, however, recommended a much more generous test. For trials in the higher criminal courts it proposed that legal aid should be available as of right to all who qualified on the means test - and the same for all trials in magistrates' courts in which there is a right of election to have trial in the crown court. Moreover, in cases triable only before magistrates, legal aid should be available unless the court was satisfied first that there was no likelihood of a custodial sentence or danger of substantial damage to the reputation or livelihood of the accused and, secondly, that adequate presentation of his case did not require legal representation. ${ }^{13}$

For proceedings in civil courts the test is whether there is a reasonable chance of success and whether, in all the circumstances, it is reasonable for the applicant to have legal aid. This test is applied by committees of local practitioners acting as scrutineers on behalf of the Law Society as stewards of the legal aid scheme. Here, too, the Royal Commission has recommended a broader test - to take ac-

13 Id. at 158.

4. 
count of factors such as injury to reputation, status, civil rights or personal dignity. ${ }^{14}$ Law centres do not have to submit their cases for any external review of the merits unless they wish to apply for legal aid for their clients - in which event the rules are the same as for clients of private practitioners. The cases that do. not get legal aid include small claims (because it is considered that it is not reasonable in all the circumstances that it be granted), and test cases on points of law of importance where the prospects of success on the facts are unpromising. A proposal by the Evershed Committee in 1953 , that points of law of general public importance should be financed out of public funds where the Attorney General certified the case to be suitable for such treatment, has not been implemented.

\section{The Means Test Limits Should Include as Great a Proportion of the Population as Possible}

It has been a serious reproach in most countries with a legal aid scheme that it applies only to the very poor. Moreover, the problem has been aggravated by inflation. In England, for instance, it has been estimated that whereas in 1964 some 60 per cent of married couples under the age of 65 with children were eligible for civil legal aid, by 1973 the proportion had gone to about 20 per cent. When the Lord Chancellor announced new means test limits in February 1979 , he claimed that it would bring 70 per cent of married couples with two children within the scheme. ${ }^{15}$ It seems to be only the Swedish system so far that has extended the legal aid scheme to the great bulk of the population. The English Royal Commission, however, made bold recommendations in this direction. It recommended that the average person should be entitled to free legal aid. A married man with two children should qualify for free legal aid with a gross income of up to $£ 7,000$ (or say $£ 3,000$ disposable) at April 1979 levels. Up to $£ 10,000$ capital should also be allowed for those getting free legal aid - not counting the value of the home. ${ }^{16}$ This would represent a very considerable increase on present English rates.

14 Id. at 140.

15398 Parliamentary Debates, House of Lords (5th series) 894 (1979).

161 Report of the Royal Commission on Legal Services, supra note 2, at 122-24. 
The Commission also proposed a free non-means-tested half an hour of diagnostic advice ${ }^{17}$ and the total abolition of the means test for criminal cases tried in the magistrates' courts. ${ }^{18}$ It also suggested that the upper ceiling for civil legal aid should be abolished, so that even the rich could be entitled to legal aid in costly proceedings. ${ }^{19}$

\section{If There Is a Contribution System, It Should Not Be Such as to Deter Eligible and Deserving Applicants}

In many countries those who receive legal aid can be asked to pay a contribution. If the contribution is fixed at too high a level, however, it may deter some potential applicants. In the English system, for instance, the contribution was fixed at one third of the difference between the limit for free legal aid and the applicant's disposable income, and in the case of capital, the whole of the difference between the free limit and disposable capital. In 1979 the fraction of one third was reduced to one quarter, and the Royal Commission recommended that it be further reduced to one fifth or alternatively to a sliding scale. ${ }^{20}$ The contribution figure can be very high, and, obviously, it is liable to deter applicants unless the likely costs of the action are proportionately high. If more of the population are to be brought within the scheme by raising the means test limits, this policy must be combined with a proportionate lowering of the contribution.

\section{E. The Limited Liability System for Legal Aid Costs Should Include Not Only the Costs of the Applicant But Also His Opponent's Should the Applicant Lose}

In countries where the loser in litigation is liable to pay the whole or a substantial part of the costs of the winner, it is important that this be covered by a grant of legal aid. If an applicant is covered for his own costs, but faces the possibility of paying his opponent's costs if he loses, he will be more likely to be deterred from pro-

17 Id. at $134-35$, para. 13.5 .

$18 \mathrm{Id}$. at 164 , para. 14.31 .

19 Id. at 121 , para. 12.32 .

$20 I d$. at 125. 
ceeding with the case. Under the English system the legally aided loser cannot be asked to pay for his opponent's legal costs more than is reasonable. This formula is interpreted to mean that he should be asked to pay as a loser the same amount (if any) as he has been required to advance in respect of his contribution towards his own costs. If, therefore, his own contribution is nil, he will not pay anything towards the costs of the winner. If his contribution is, say, $£ 100$, he can be asked to pay another $£ 100$ towards the winner's costs. The Royal Commission suggested however that the assisted person should not have to pay anything in excess of his own contribution toward the costs of the successful litigant. ${ }^{21}$

F. Ideally, the Legal Aid System Should Also Cover the Costs of the Non-Legally-Aided Defendant Who Successfully Resists Proceedings Brought under Legal Aid

The English system has made provision since 1964 for the costs of the defendant who has been sued unsuccessfully by a legally-aided plaintiff. He must show that it is "just and equitable" that he should get his costs on the basis that he would otherwise suffer severe financial hardship. But this test is very generously interpreted - even insurance companies have been able to claim its benefits. ${ }^{22}$ The total sums involved are, however, small, partly, no doubt, because most legally-aided actions succeed. In 1977-1978, out of a total of $£ 52.1$ million gross spent on the Civil Legal Aid Fund, only £0.07 million was attributable to this source. It can therefore be included in a scheme with little danger that it will cost an exorbitant amount.

\section{G. Remuneration of Lawyers for Legal Aid Work Must Be Sufficiently High to Be Attractive}

In all systems legal aid fees seem to be lower than those available to lawyers paid privately. But if the level of fees is so low as not to

21 Id. at 147 , para. 13.55 .

22 See Hanning v. Maitland (No. 2), [1970] 1 Q.B. 580; General Accident Fire and Life Assurance Corporation Ltd. v. Foster, [1972] 3 All E.R. 877; Davies v. Taylor (No. 2), [1973] 1 All E.R. 959. 
be profitable, it means either that the work will be done by very young lawyers or that it will be very thinly spread. Most established lawyers will be unable to take more than a very small number of unremunerative cases. If fees are to keep abreast of inflation, it is also vital that there be some appropriate mechanism for regularly revising the figures. From the point of view of accountability, this mechanism should be given access to information about the profitability of different categories of legal aid work. Without such information legal aid fee schedules are based on guesswork.

The Royal Commission adopted the view that there should be one independent Fees Advisory body to take over from the multiplicity of bodies that issued scales, fixed fees and issued guidelines regarding fees. "We believe that the time has come to put the means by which scales, fees and guidelines are settled on a more regular, better informed and more closely coordinated basis." ${ }^{23}$ ) It should give its reasons and findings of fact. It should issue an annual report. Its first priority might be legal aid fees, which required "urgent review". ${ }^{24}$

\section{H. Adequate Funding at the National Level}

It goes without saying that adequate funding is a critical aspect of legal aid. The political strength of the legal aid/legal services movement varies from country to country. (In England there has been a notable expansion in recent years. The Government's Expenditure Plans 1978-1979 to 1981-1982 showed that annual net expenditure on legal aid, which was $£ 55$ million in $1972-1973$, and $£ 83$ million in $1976-1977$, was due to rise to $£ 103$ million by $1981-1982$. These figures do not include the moneys spent on public sector legal services, which in 1977-1978 were some $£ 2$ million.)

The system of judicare adopted in England has one feature that is most valuable as a way of increasing the level of funding for legal aid. This is the fact that the aggregate expenditure on legal aid is more controlled by individual committees and courts granting legal aid than by the Treasury through the setting of an overall budget. Parliament must, of course, approve the funds, but if extra expen-

231 Report of the Royal Commission on Legal Services, supra note 2, at 567-68. ${ }^{24} \mathrm{Id}$. 
diture is required, a supplementary budget is prepared. The legal aid authorities both in civil and criminal legal aid, therefore, do not have ceiling figures they cannot exceed. Legal aid committees and, in the criminal field, the courts simply determine legal aid applications on an individual basis. The administrators do not have to be concerned as to whether the effect of the aggregate of individual decisions will be to exceed the projected national figure. Of course, if the Treasury considers that the level of funding is too high, it will urge the relevant government departments to find ways of securing economies. Thus, the recent decision by the Labour Government to abolish legal aid for divorce hearings was a direct result of such a search for economies. ${ }^{25}$ Nevertheless, the English legal aid system does not work within so severe constraints as to funding as is the case with systems where there is a fixed overall budgetary ceiling.

The fact that legal aid expenditures in England have risen enormously in recent years in spite of intense pressure for economies in the field of public expenditure is, I believe, due at least partly to the open-ended nature of the commitment to fund legal aid. The general heightening of consciousness during the past decade about the need for legal services was reflected in a steady rise in the number of applications for legal aid, and legal advice and assistance. The authorities were not inhibited by any funding barriers from responding to this growing call for legal aid from applicants.

\section{Should Funding for the Public Sector Be on a Central or a Local Basis?}

One debate that has been important in England, and that may have analogues elsewhere, is whether law centres should be funded by central or by local government. In England many law centres have drawn the whole or a part of their moneys from local government sources. The disadvantage is that they have, in some instances, found themselves subjected directly or indirectly to political pressures to desist from particular forms of action. The Law Centres Federation has concluded that, on balance, they would be better

25 The decision was based on a new procedure which made the hearing unnecessary for obtaining an undefended divorce. Legal aid can still be obtained for contested divorces and for any issues that arise regarding children and property. 
insulated from the impact of such pressures by central funding. Even then, the risk of the funds being reduced at the behest of enemies of legal services remains. (President Nixon came close to smashing the American federal legal services enterprise.) But sophistication about the value of and need for legal services is likely to be greater at the central than at the local level. It may also be easier to mobilise counter-pressures against a threatened reduction in funding for legal aid at a central than a local level - through the press, the professional bodies, members of Parliament, etc.

The recommendation of the Royal Commission on this issue was that law centres should be financed by central rather than local moneys, but that in return the law centres should accept direction from the central authority on such matters as the type of work they could do, records to be kept, insurance, annual reports, etc. ${ }^{26}$

\section{J. How Large Should the Public Sector in Legal Services Be?}

There is no way of determining the "proper" size of the public sector. In the foreseeable future there will always be a need for more law centres (and other salaried lawyers) than there will be money to provide them. How many more is largely a question of political and fiscal judgment. Even in areas with many private practitioners there will be uses for a law centre - and the more so if law centres move increasingly into work for communities and groups, since this is work that is virtually not done by private practitioners at all. I would expect the public sector to grow in England in the next decade from 30 or so to 100 or more law centres.

\section{K. Where Should Staff Offices Be Situated?}

It is, in my view, somewhat arbitrary where salaried lawyers are placed, in that there are so many areas that need lawyers - or more lawyers. One might start with the areas of greatest deprivation, where there are likely to be few, if any, lawyers; but in such areas they may, perforce, have to do ordinary traditional lawyer's work -

261 Report of the Royal Commission on Legal Services, supra note 2, at 86-88. 
divorces, criminal defences, etc. In such areas law centres will be unable to make their distinct contribution.

The Royal Commission drew attention to the fact that the need for services existed not only in the big cities where concentrations of poverty were most obvious but also in rural areas among a more widely scattered population. It would probably be uneconomic to have law centres in rural areas, but a possible solution to the problem was to have law centre lawyers attached on secondment to other advisory agencies which had facilities in rural areas. ${ }^{27}$

\section{Can Ways Be Found to Create Controls over the Quality of Legal Work?}

At present there are virtually no controls over quality, save for the marginal control exercised by the complaints and disciplinary machinery. In England there is now a statutory Lay Observer to whom a client can complain if he is not satisfied with the way the Law Society has handled his complaint. But most clients do not complain even when they have something to complain about - and of those who do, many are ill-equipped to identify their grievances with any degree of accuracy. Moreover, complaints by individual clients are treated by the profession as exceptional. Even if the complaint is upheld, it would rarely lead to any general lifting of standards by the profession.

A more systematic approach to the problem of standards is needed. This might come from some form of official or semi-official research body able to evaluate the way the profession does its work in the ordinary case. It would have to be given the capacity to examine random samples of cases. The results could then be published as representative of the standards of the profession as a whole - without identifying black sheep and without having to rely on client complaints.

The Royal Commission did not make any recommendation to this effect. It contented itself with proposals to broaden the profession's approach to complaints. It suggested in particular that the professional body should be prepared to deal with complaints alleg-

27 Id. at $89-90$. 
ing actionable negligence (instead of referring complainants to their legal rights), and also complaints alleging bad workmanship that fell short of professional misconduct. ${ }^{28}$ It proposed that laymen should be involved not only as now in the final stages of disciplinary hearings but also in the earliest stages of sifting complaints. ${ }^{29}$ Letters to complainants should be written with greater sympathy. Wherever possible they should be interviewed. ${ }^{30}$ Details of complaints received and action taken should be published annually. ${ }^{31}$

\section{There Is a Need in Every System for Adequate Statistics and Re- search}

One essential feature of every system is an adequate annual report on legal aid statistics. From this point of view the English system is relatively fortunate. The Law Society's annual report on the civil legal aid scheme now runs to some 50 pages and includes a mass of statistical detail. The quality of reporting on the criminal legal aid system is, however, very much less satisfactory - largely because the Law Society has no jurisdiction in regard to criminal legal aid other than in the magistrates' courts, and the Home Office has lacked the will to produce a full report. (Following the Report of the Royal Commission, responsibility for criminal legal aid was shifted in 1980 from the Home Office to the Lord Chancellor's Department; but it remains to be seen whether this will result in an annual report on the scheme.) Basic statistics must, of course, be supplemented by occasional studies of particular problems. Somewhere in the system there should be an official unit with the capacity to investigate problems that may come up from time to time. This could be the same research team as that referred to in the previous section whose function would be to inquire into the quality of legal services.

The Royal Commission recommended that the overall advisory body on legal services (see below) should have the function, inter. alia, of carrying out research on the provision of legal services. The research should include the power to run pilot and experimental projects. ${ }^{32}$

\footnotetext{
28 Id. at 342-43.

$29 \mathrm{Id}$. at 347 , para. 25.45 .

$30 \mathrm{Id}$. at 346, para. 25.38.

$31 \mathrm{Id}$. at 341 , para. 25.19.

${ }^{32} I d$. at 63-64, paras. $6.20,6.22$.
} 
N. There Is a Need in Every Legal Aid System for the Involvement of Laymen and for External Review Bodies

The English system has so far experienced the following types of external participation in the affairs of the profession:

1) Standing official bodies:

a) Lord Chancellor's Legal Aid Advisory Committee - set up under the Legal Aid and Advice Act 1949. Its chairman and about half the members have always been laymen. It publishes an annual report and commentary on the report of the Law Society on the civil legal aid scheme.

b) Lay Observer - for complaints against solicitors.

c) Lay members of the Bar's and the Law Society's Disciplinary Tribunals - one out of the three members of the Tribunal has to be a layman, drawn from a panel appointed by the Lord Chancellor.

d) Lay members of the Law Society's statutory legal aid committee - two laymen added voluntarily by the Law Society in 1977 to a committee consisting only of lawyers.

e) Lay members of the management committees of law centres - virtually every law centre has a local management committee, and in all of them laymen form either a majority or a substantial minority. In the Law Society's statement on waivers (see above) it is provided that "although not a condition for the grant of a waiver, it is considered that a majority of the voting members of the Management Committee of a salaried service should normally be able to represent the interests of the recipients of the service".

f) A Legal Services Committee established experimentally in Greater Manchester by the Law Society in 1977 - with fifteen members, of whom eight are laymen and seven are lawyers.

2) Ad hoc bodies:

a) The National Prices and Incomes Board - made three reports on solicitors' remuneration: 1968 (Cmnd. 3529); 1969 (Cmnd. 4217); 1971 (Cmnd. 4624).

b). The Monopolies and Mergers Commission - has made four reports in the past few years on aspects of the profession: on restrictive practices in all the professions (1970, Cmnd. 4463); on advertising by solicitors (1976, No. 558); on advertising by barristers 
(1976, No. 559); and on Queen's Counsel appearing alone (1976, No. 512).

c) The Royal Commission on Legal Services - appointed in February 1976 with terms of reference to inquire into all aspects of legal services.

The Royal Commission made proposals for the expansion of the use of laymen and also for the establishment of new review bodies.

It saw a need for laymen in various contexts. One was on relevant committees of the professional bodies, though not on the central elected committees (the Senate of the Inns of Court and the Bar or the Council of the Law Society). But it thought that the professional bodies should co-opt laymen onto committees dealing with such matters as remuneration, education, public relations, discipline and professional standards. ${ }^{33}$ It wanted to see laymen (one of whom should be chairman) on the proposed new Fees Advisory Committee. ${ }^{34}$ It also confirmed its belief in the value of local committees consisting mainly of laymen to supervise the work of law centres though it suggested that they should be advisory rather than management committees. ${ }^{35}$ ("This local committee should ensure that the law centre is sensitive to local circumstances and in a position to meet the needs of the local community." 36 )

But the most important recognition of the need for both lay participation and external review bodies was the recommendation by the Royal Commission that there be established a new Legal Services Council and Regional Legal Services Committees. The Legal Services Council would be an expansion of the concept of the Lord Chancellor's Legal Aid Advisory Committee, which the Commission said had in the past years "made a significant contribution to progress in the field within its terms of reference". It had succeeded in "bringing together a large number of diverse interests and in promoting public discussion". It had reported "year by year, in clear and uncompromising terms, on the deficiencies of the present system". "The public, Parliament and the responsible Minister rightly attach importance to what it says." 37 But the terms of reference of the

\footnotetext{
33 Id. at 329 , paras. $29.41-42 ; 440$, para. 32.77 .

$34 \mathrm{Id}$. at 568 , para. 37.94 .

35 Id. at 85 , para. 8.26 .

36 Id.

37 Id. at 62 , para. 6.14 .
} 
present Advisory Committee were too narrow, since they only covered legal aid and advice and assistance in civil matters. The Commission said it was satisfied that if such a body was to operate satisfactorily, its terms of reference should cover not merely all legal services funded out of the public purse (civil legal aid, criminal legal aid, legal advice and assistance and law centres) but legal services of every description. ${ }^{38}$

The composition of the proposed new Council would be somewhat similar to that of the Lord Chancellor's Advisory Committee a mixture of lawyers and laymen representing organisations involved in the provision of legal services (trade unions, Citizens' Advice Bureaux, etc.) and the public. It would be a part-time body with a small secretariat and research capacity. Its functions would be to review and to carry out research on the provision of legal services, to prepare proposals for the more effective provision of such services, to keep the implementation of such proposals under review or even to accept direct responsibility for implementing them, and to carry out such executive functions as might be referred to it by the Lord Chancellor. It would have an overall advisory role. 39 ("Somewhere, legal services as a whole have to be considered so that gaps can be identified, priorities tested, and proposals for change put into context. This is a necessary condition of considered action by both government and the profession." ${ }^{40}$ ) The composition and remit of the Council should have "sufficient authority to command respect with government, the profession and the general public". ${ }^{41}$

In addition, the Commission proposed that there be similarly constituted regional committees to monitor the provision of legal services in their area and to coordinate regional services and agencies: The model would be the new Manchester Legal Services Committee (see above), but instead of being appointed by and reporting

38 Id. at paras. 6.14-15. The recommendation went beyond what was recommended by the Lord Chancellor's Advisory Committee itself. It had urged in its evidence that its own terms of reference should be expanded simply to include all publicly financed legal services. The case for an advisory body covering all legal services was argued by the writer in his evidence and in M. ZANDER, supra note 6, at 265-67. See also Zander, Who Should Manage Legal Services?, in Access to Justice: Emerging Issues and Perspectives 389 (Alphen aan den Rijn/Milan, Sijthoff and Noordhoff/Giuffrè, Vol. III of the Florence Access-to-Justice Project Series, M. Cappelletti \& B. Garth eds., 1979).

391 Report of the Royal Commission on Legal Services, supra note 2, at 63.

$40 \mathrm{Id}$. at para. 6.21.

41 Id. at 64-65, para. 6.25 . 
to the Law Society it would be appointed by and would report to the Lord Chancellor and to the Council for Legal Services. ${ }^{42}$

The Commission therefore accepted the case for improved systems to promote accountability in the field of legal services and a standing body combining lawyers and laymen at both the local and the national level to keep a watching eye on all developments in the field. The Report of the Royal Commission on Legal Services in Scotland went even further. This Report, which was published in May 1980, proposed that there should be not merely an advisory committee but a Legal Services Commission with executive functions to run legal aid, law centres and all other publicly funded legal services. ${ }^{43}$ 


\title{
LEGAL SERVICES TO THE POOR:
}

\author{
AN AMERICAN REPORT \\ by \\ GARY BELLOW \\ Professor of Law, Harvard University
}

Any report contains some mix of description and assessment. This account of problems and progress in the evolution of subsidized legal services to the poor in the United States is no exception. It is written with some skepticism about the so-called success ${ }^{1}$ of the U. S. legal aid system and the shape it has begun to take. Hopefully, an exploration of these developments will add to discussion of the elusive idea of "access," and the role that day-to-day legal representation can play in achieving it.

\section{The Controversial Past}

\section{A. The Sixties-Legal Services and The War on Poverty}

Historically, legal assistance to the poor in civil cases in the United States was provided by $a$ ) individual lawyers on a voluntary basis, or $b$ ) private legal aid societies supported by charitable con-

1 Assessments - and definitions of success - have not been uniform. See, e.g., A DECADE of Federal Antipoverty Programs: Achievements, Failures and Lessons 315 (New York, Academic Press, R. Havemann ed., 1977). However, in general, I think it fair to say that the prevailing view in the Bar, the bench and Congress is that, despite the level of controversy in its early years, the legal services program is an example of a very successful federal program. This has been the thrust of much of the recent scholarly evaluation of the program as well. See, e.g., J. Handler, E. Hollingsworth \& H. Erlanger, Lawyers and the Pursuit of Legal Rights (New York, Academic Press, 1978); P. Morris \& M. Rein, Dilemmas of Social Reform: Poverty \& Community Action in the United States 267 (Chicago, Aldine, $2 \mathrm{~d}$ ed., 1973): "Of all the new services initiated by the anti-poverty program the most militant - the legal advocacy of poor people's rights - seems also to have had more influence on institutions, and won more substantial benefits for the poor than any other." 
tributions and limited municipal funding. ${ }^{2}$ By 1964 , approximately 150 such societies employing 600 lawyers were expending four million dollars annually in this way. This was estimated to have been less than two tenths of one percent of what was expended on legal advice and representation in the United States at that time. ${ }^{3}$

With the inclusion of legal services among the programs of the Office of Economic Opportunity's War on Poverty, this system was radically altered. ${ }^{4}$ In less than a decade, over 60 million dollars were being spent each year by the federal government on legal assistance to the poor, and over 2,500 lawyers had been attracted into full-time legal service work in separate cities and counties across the United States. ${ }^{5}$ During the same period, the leaders of the National Bar and many members of the legal profession came to support levels and forms of federal intervention into the existing legal aid system which were unthinkable only five years earlier. ${ }^{6}$

The story of these developments and the conflict and controversy that attended them has been ably told by Earl Johnson in his book, Justice and Reform. ${ }^{7}$ I only want to make two observations about these formative years.

First, it is important to bear in mind that, although accounts of the program have focused on developments at the national level, its structure was highly decentralized and its impact was and is determined much more by the character of service in the majority of its neighborhood offices than by the policy decisions and rhetoric of its national leaders or a few politically active and controversial local

2 R. Smith, Justice and the Poor (New York, Scribner, 1919); E. Brownell, Legal Aid IN THe United States (New York, Lawyers Co-operative, 1951).

${ }^{3}$ Hearings on the Legal Services Program of the OEO Before the Subcommittee on Employment, Manpower \& Poverty of the Senate Commission on Labor \& Public Welfare, 91st Congress, 2d Session, at 7.2 (1971); see also statistics published annually by the National Legal Aid \& Defender Association.

${ }_{4}$ Office of Economic Opportunity, Legal Services Program, First Annual Report of the OEO Legal Services Program to the ABA (1966); the program was not formally included in the statute. Economic Opportunity Act of 1964, 42 U. S. C. $\S 701$ (1964). Legal services was initially authorized by the director of $\mathrm{OEO}$ as a project of the Community Action Program. See Office of Economic Opportunity, Community Action Guide (1965).

5 There were, by 1974, 250 separate programs and 900 offices providing service. Parker, Impact of Federal Funding on Legal Aid, 10 California Western Law Review 503, 504 (1974). It is estimated that, at the pre-1964 rate of growth, it would have taken the program 100 years to reach the level of expenditure achieved by the OEO program in 1967. See Stumpf, Law and Poverty: A Political Perspective, 1968 Wisconsin Law Review 694.

6 The earlier attitudes of the Bar are described in E. Johnson, JR., Justice AND Reform: The Formative Years of the OEO's Legal Services Program (New York, Russell Sage Foundation, 1974). For a particularly vitriolic attack on the program, see Walke, Et Tu Brute!, 1 Tennessee Bar Journal 11 (1965).

7 E. Johnson, JR., supra note 6. 
programs. Even though they were funded as a strategic arm of the War on Poverty, ${ }^{8}$ most legal services programs - whether newly funded or "add-ons" to existing legal aid societies - quickly adopted the approaches to daily service that had characterized legal aid practice prior to $1964 .{ }^{9}$ A surprising number even retained the same policies that had produced so much criticism from proponents of federal intervention. Some cases, for example, were still turned away because they might be controversial, or because the clients were not "deserving," and boards of directors of some local programs demanded scrutiny and control of staff practice well beyond what professional norms required or permitted.

At the same time, very few programs attempted to link legal services to organizing efforts in poor communities, and only a minority of programs devoted any substantial amount of resources to cases involving direct challenges to existing rules and practices. Most "law reform" efforts, about which so much has been written, were initiated or carried forward by a relatively small number of lawyers in the larger programs and in the substantive back-up centers which the program had established. 10

When we speak about legal services in the United States, we often speak as if it were a unified program with a common philosophy and approach. It is well to recall how large a gap often existed between national policy and local practice. It is also important to recognize that many of the basic structural features of the present program - and the preferences they represent - were established in the sixties. These include the following: ${ }^{11}$

8 This was clearly articulated in the program's guidelines. Office of Economic Opportunity, Guidelines for Legal Services Programs (1967) (the program was to assist in OEO's "comprehensive attack on the causes and effects of poverty").

9 Champagne, The Internal Operation of the OEO Legal Services Program, 51 Journal of URban LAw 649 (1974); McCarthy, The Consequences of Legal Advocacy: OEO's Lawyers \& the Poor (unpublished Ph.D. thesis, University of California at Berkeley, 1974).

10 See generally Note, Neighborbood Law Offices: The New Wave in Legal Services for the Poor, 80 Harvard Law Review 805 (1967); Pye, The Role of Legal Services in the Antipoverty Program, 31 Law \& Contemporary Problems 211 (1966). Debate tended to focus more on the program's goals than its realities. See Note, Competition in Legal Services Under the War on Poverty, 19 Stanford Law Review 579 (1967); Hazard, Law Reforming on the Antipoverty Effort, 37 University of Chicago Law Review 242 (1970); Hannon, The Leadership Problem in the Legal Services Program, 4 Law \& Societr Review 235 (1964).

11 Some of the observations are based on the author's experience and recollections. It is one of the ironies of academic life that one can cite almost anything for authority other than one's own memory. It is less in protest and more in frustration, however, at not being able to fully document some of the comments in this paper that I have, at times, cited myself.

For a description of the program's main features, see Bamberger, The Legal Services Program of the. Office of Economic Opportunity, 41 NOTRE DAME LAWYER 847 (1965). 


\section{Local Autonomy}

The legal services "program" was, from its inception, essentially a network of non-profit organizations governed by their own Board of Directors and engaged in providing legal services to the poor in specific geographic areas. Although local bars often argued bitterly against federal intervention, there was, particularly in the early years, relatively little Federal control or regulation of individual programs. Most of the grants went to existing legal aid societies, and virtually all programs receiving funds were supervised by boards made up of local attorneys. Indeed, the decision of the program's early leadership to fund as many individual programs as possible as quickly as possible - as a hedge against possible future cutbacks - meant that many acknowledged problems in existing programs were deferred or ignored, and new programs received only a cursory review at the initial application stage.

\section{Staff Lawyers}

Each program recruited and hired its own legal staff, which, in turn, provided direct service to clients. Although the debate still continues (and some experiments with judicare have been funded), the "staff model," for reasons that have been amply explored elsewhere, ${ }^{12}$ has been the preferred method of serving clients. This has usually meant reliance on lawyer staff; far less attention has been paid to the ways that large numbers of paralegal staff might be employed in the offices.

\section{Indigent Clients}

From its inception, only persons whose resources and income fell below specified limits - developed on the basis of Department of Labor definitions of poverty - were eligible for services. Feegenerating cases were referred to the private bar, and programs were

12 See Brakel, Free Legal Services for the Poor: Staffed Office v. Judicare - The Client's Evaluation, 1973 Wisconsin Law Review 532; Cappelletti \& Johnson, Toward Equal Justice Revisited: Two Responses to a Review, 1977 American Bar Foundation REsearch JourNAL 943; Brakel, Styles of Delivery of Legal Services to the Poor, 1977 AmERICAN BAR FounDation Research Journal 219; Mascotti \& Corsi, Legal Assistance for the Poor: An Analysis and Evaluation of Two Programs, 1967 Journal of Urban Law 483. 
not encouraged to develop any sliding scale or partial payment system for those who were not eligible for free services and could not pay a private attorney. Strict income eligibility limits were thought necessary to reduce opposition from the large number of small firms and single practitioners who feared that the program would seriously affect their business. As a result, the recent growth of legal clinics, prepaid legal insurance and other methods of reaching the large numbers of marginally indigent, working poor and middle class who are effectively priced out of the "fee-for-service" system has taken place with very little input from, or contact with, the "no fee" legal services system.

\section{4. "Law Reform" Specialization}

Very early in its history, the program articulated a mix of goals, and encouraged both day-to-day legal representation and challenges to existing rules and practices which adversely affected the clients and communities served. ${ }^{13}$ In a few years, however, it became clear that, for all practical purposes, this latter role would be assigned to specialized units within programs or to back-up centers specially created to handle large litigation or legislative advocacy in specific subject matter areas. ${ }^{14}$ The attorneys at the local level were considered too inexperienced, unskilled and pressured by day-to-day demands for service to do what was considered more complex legal work. Status, salaries and opportunities for employment, both in legal services and upon leaving it, soon began to reflect this assumption.

\section{Structural Independence}

Finally, it is worth noting the continuing efforts by the Bar and the legal services staff of the Office of Economic Opportunity to obtain more independent status within the OEO at both the national and regional level and more direct access to Congress and the White House. The premise was that the program would be

13 See Office of Economic Opportunity, Legal Services Program Evaluation Manual (1967). See also Office of Economic Opportunity, The Poor Seek Justice (1967).

14 See Note, Beyond the Neighborbood Office - OEO's Special Grants in Legal Services, 56 Georgetown Law Journal 742 (1968). 
far more efficient administratively and less vulnerable politically if it could be disassociated from the controversy that had already begun to swirl around the poverty program. Moreover, Bar support in Congress could more easily be marshalled if the Bar were clearly the program's primary constituency. No substantial effort was thus made to build any larger coalition to back the program's concerns and goals. ${ }^{15}$

\section{B. The Seventies-Legal Services and the Legal Services Corporation}

Despite the relatively small amount of "radical" activity in the program, by 1970 it had, nevertheless, come to be regarded, at least in the White House, as a prime example of the misplaced energies of the War on Poverty. Vice President Spiro Agnew labeled its lawyers "ideological vigilantes," 16 and year after year opposition was mounted against its appropriations in the Congress. Within the OEO this assault was accompanied by a number of very highhanded efforts, sanctioned by the White House, to "bring the program under control." 17

Why such a small program, in terms of total federal social welfare expenditure, should have generated such ire is still somewhat difficult to understand. Certainly, a number of the successful "law reform" cases upset important aspects of the status quo and created

15 For arguments urging these views, see Pye \& Garraty, The Involvement of the Bar in the War Against Poverty, 41 Notre Dame LAwyer 847 (1966); see generally Pious, Congress, The Organized Bar and the Legal Services Program, 27 Wisconsin Law Review 418 (1972). Program independence from the Community Action Division of OEO was guaranteed in a memo by the Director of OEO as early as 1965 . Pious, $i d$. at 412 . The program gained new full independent status within OEO in 1969. Note, Legal Services - Past and Present, 59 CoRNELL LAW REVIEW 960, 965 (1974).

16 Agnew, What's Wrong with the Legal Services Program?, 58 American Bar AssociaTION JOURNAL 930 (1972).

17 This included firing the Director and Deputy Director of the program. New York Times, December 1, 1970; Boasberg, Washington Beat: Upheaval in OEO's Legal Services Program, 3 URBAN LAWYER 135 (1971). Between 1971 and 1974, the program experienced a $13 \%$ decrease in the number of attorneys, a four million dollar decrease in funds, and a $40 \%$ drop in the number of offices. Law reform was abandoned as a goal, the National Advisory Committee to OEO was abolished, and a rationale for phasing out the back-up centers was prepared. Arnold, The Knockdown, Drag-out Battle Over Legal Services, Juris Doctor, April 1973 , at 4. Some of the efforts by OEO's Director to dismantle the program were enforced by Federal Courts. Gov. Employees, Local 2677 v. Phillips, 338 F. Supp. 60 (1973), and a subcommittee of the House of Representatives accused him "of arrogance, subverting national policy, encouraging summer turmoil in the streets and using a 'meat ax' on the program." New York Times, February 28, 1973. 
new antagonisms toward the program. ${ }^{18}$ In addition, even in places where the attorneys were not very aggressive, the very appearance of lawyers altered the ways in which established institutions functioned toward the poor and made it more costly to continue existing arrangements. In one town in California, for example, a city attorney announced at a City Council meeting that it had gotten "just too expensive to fix trouble-makers [read: unionizing employees] anymore... we'll just have to start obeying the rules or get rid of those damn lawyers." 19

Perhaps equally important in generating controversy was a) the general climate of those years, $b$ ) the confrontational style of some of the program's attorneys, $c$ ) the vigorous support and protection they received from the national office of OEO, and $d$ ) the willingness of the national policy-makers to publicly legitimate efforts at reform and change. In a speech to the Bar in Chicago, for example, Clinton Bamberger, the first national director of the legal services program, made the following statement: ${ }^{20}$

We cannot be content with the creation of systems of rendering free assistance to all the people who need but cannot afford a lawyer's advice. This program must contribute to the success of the War on Poverty. Our responsibility is to marhsall the forces of law and the strength of lawyers to combat the causes and effects of poverty. Lawyers must uncover the legal causes of poverty, remodel the systems which generate the cycle of poverty and design new social, legal and political tools and vehicles to move poor people from deprivation, depression, and despair to opportunity, hope and ambition.

Earl Johnson, who followed Bamberger as director, took a similar and equally public approach to reform. ${ }^{21}$ Even if not much of what Bamberger and Johnson urged was, in fact, occurring, there was certainly, among those who saw stability and authority in the nation gradually unravelling, concern that it might.

In any event, whatever the sources, the legal services program in

18 Attempts to quantify the impact of these efforts are contained in E. JoHnson, JR., supra note 6.

19 Bellow, The CRLA Experience (unpublished manuscript, 1973).

20 Address by E. Clinton Bamberger, Jr., to the National Conference of Bar Presidents, December 19, 1966.

21 See, e.g., Johnson, Director's Column, in LAw in Action (April and May 1967); Johnson, Harvard Conference on Law and Poverty (March 17-19, 1967). 
the early seventies found itself in deep political trouble, beleaguered administratively within $\mathrm{OEO}$, and the subject of continuing criticism and opposition from a growing number of public officials and elected representatives. In this posture, legal services staff at OEO, supporters of the program in Congress, and those active in the legal services community itself turned to the national Bar leadership for help. The result was a united effort to extricate legal services from the "politics" of OEO and to lodge it in a separate non-profit corporation which could administer the congressionally appropriated funds allocated to the program. ${ }^{22}$ These efforts reached fruition in 1973 with the passage by Congress of the Legal Services Corporation Act.

Although there is much to be said about this statute and the way the Legal Services Corporation has administered it, ${ }^{23}$ what is most significant about the "new" legal services program is the degree of continuity it shares with its predecessor. Despite a great deal of talk about the need for a different program, ${ }^{24}$ the statute essentially sets out legislative authority for what legal services had been doing under the OEO program. This includes lobbying, representing groups, and engaging in class action litigation. Even the controversial back-up centers - the mainstays of the OEO program's law reform efforts are continued. In fact, under the Corporation, the number of such centers, and specialized litigation units has grown. The few studies that we have on the subject suggest that the amount of "law reform" activity in the program has actually increased since the Corporation came into existence. ${ }^{25}$

What has been very different about the post-OEO period, however, is the way the program has been publicly described and justified. The speeches and congressional presentations of program leaders no longer contain references to social change as an important concern of the program. ${ }^{26}$ Gone also (or at least muted) are the vociferous debates over whether the staff or judicare model is most

22 See, e.g., Kantor, The National Legal Services Corporation: The Congress and Legal Services - An Analysis, 1971 NLADA BriefCASE 6.

23 See generally George, Development of the Legal Services Corporation, 61 CoRnell LAw Review 681 (1976); Buck, Legal Services Corporation: Finally Separate But Not Quite Equal, 27 Syracuse Law Review 611 (1976); Note, Depoliticizing Legal Aid: A Constitutional Analysis of the Legal Services Corporation Act, 61 CoRnell Law Review 734 (1976).

${ }^{24}$ Arnold, Whither Legal Services, JURIS Doctor, February 1971.

25 J. Handler, E. Hollingsworth \& H. Erlanger, supra note 1.

26 See, e.g., Legal Services Corporation, Annual Reports (1975-1978). 
appropriate to the program's goals. This issue has now been deferred until a study of 39 experimental programs has been completed. ${ }^{27}$

In place of these concerns is an almost exclusive focus, publicly and administratively, on "access," and how it is to be realized. Graphs and tables have replaced examples of practices changed and wrongs righted, the staples of the program's public presentations in the sixties. The immediate goal is now "minimum access" - defined as two lawyers per ten thousand poor people in the United States (there are ten lawyers per ten thousand persons above the poverty line). All discussions of this goal are carefully designed to soften any polarizing rhetoric and to defuse the sort of opposition that plagued the program in the sixties.

As a short-term funding strategy, this approach has been extremely effective. Opposition has been muted. Acceptance and confidence in the program in both the Bar and Congress has increased. The specific target set by the minimal access ideal has won supporters and generated substantial growth in the funding available for legal services to the poor. At the time of writing, Congress has approved an annual appropriation of 300 million dollars for the Corporation, over three times the annual level when the Corporation was first established. There are now over 5,000 lawyers and 1,300 paralegals providing services in 335 programs throughout the country. ${ }^{28}$ In addition, the Corporation has a) expanded the funds available for training and staff development throughout the program, b) enlarged the number and responsibilities of the back-up centers (now called National Support Centers), c) created a research institute concerned with long-term aspects of law and poverty as a major division of the Corporation, and $d$ ) funded a National Clients Council and special recruitment efforts to attract attorneys into legal services work (The Reggie Program). In general, under Corporation auspices, the size, scope and sophistication of the legal services program has been significantly enlarged.

At the same time, the Corporation has continued to give considerable latitude to individual program initiatives and to support programs whose activities generate controversy. In many ways, the

27 The authorization for the study is contained in the Legal Services Corporation Act of 1974. The Corporation has expended over three million dollars annually for a "Delivery Systems Study" under this authorization.

28 Legal Services Corporation, Annual Report (1978). 
protection now given by the Corporation to local programs, through regulation and staff activity, is greater than that offered in the sixties. It is surely one of the many ironies of the seventies that the so-called conservative appointments of President Nixon to the Corporation's Board should have played - as they have - such an important role in this history. ${ }^{29}$

\section{The Uncertain Future}

Nevertheless, as the seventies draw to a close, persistent questions about what the program is and should be accomplishing remain. Like its predecessor, the Legal Services Corporation has managed to avoid a number of recurrent problems which have been with us virtually since the program's inception. In the sixties, these problems were blurred by the program's newness and the intensity of opposition which a small number of its lawyers and projects generated. In the seventies, a successful growth strategy permitted the same dilemmas to be deferred. In the eighties, the question of what we are trying to do and the problems we confront in doing it may have to be much more squarely faced.

\section{A. The Problem of Political Support}

Since its inception, the legal services program, like any other federally funded program, has had to compete in the budgetary process for funds and in a variety of political forums for protection and survival. In doing so, it has had to search for allies and for a rationale to explain and justify its existence and expansion. The unavailability of a "natural constituency" (other than certain national Bar leaders) has been a continuing problem for the program's directors.

I will not try at this point to explore in detail the complex choices that this problem poses. From its inception, for example, the program might have attempted to align itself more closely with those liberal democratic groups that have generally supported social welfare programs for the poor. But to some degree this would

29 The Board of Directors is made up of 11 voting members appointed by the President, with the consent of the Senate, for three-year terms. The Act requires that the Board meet four times each year. 
surely have undermined the willingness of the organized Bar to function as an aggressive lobby for the program and diluted the ideological force of an "apolitical" appeal to access as a rationale for expanding program funds. Similarly, the leadership of the program might have sought to characterize the program's work as law enforcement, emphasizing its similarities in function and impact to the Justice Department and other law enforcement agencies. ${ }^{30}$ This has the advantage of separating the legal services program from other social welfare programs with which it has to compete for funds, giving it access to the relatively large and open-ended law enforcement funds which Congress appropriates each year, and providing a rationale for focusing resources on particular problems and targets. But this approach has a number of disadvantages as well, ${ }^{31}$ and has never been satisfying to those who work in the field. ${ }^{32}$

Having been involved myself in some of the debates on these questions, I frankly do not know whether the choices of a) the organized bar as the major constituency of the program, $b$ ) the very poor as the prime focus of the program or $c$ ) access as the program's primary rationale were necessarily the best ones. What I do know is that the problem of support for future budget increases is a serious one. With the goal of "minimal access" in reach this year, it is hard to see what new formulation of purpose and need will provide a compelling rationale for further expansion of funds. Since the program lacks any constituency with political muscle for increases, Congress, having been given a target, may well insist that the minimum remain a maximum.

Unfortunately, that goal will leave the program well below anything that approaches an adequate level of funding. Admittedly, in light of the growth of recent years, this statement sounds excessive, but it must be remembered that most of the new money went into areas where there was previously no service at all. ${ }^{33}$ 1977).

30 G. Bellow, testimony before Board of Directors, Legal Services Corporation (May

31 For example, it would probably increase the influence of the Attorney General on legal services funding and alter the committees and subcommittees in the Congress that would be concerned with its appropriations.

32 A similar cost-benefit analysis would have to be made of the decision to stay away from efforts to extend legal services to segments of the population above the poverty line.

33 Almost 27 million dollars were spent in 1977 to "expand service to new areas." In 1978 , in contrast, less than six million dollars were spent for "program improvement." Legal 
Existing programs - which are feeling the brunt of the largest caseloads - have received relatively little new money. In many of them salaries are shockingly low, ratios of support staff to lawyers grossly inadequate and needed money for program improvements non-existent. It is very, very difficult to keep experienced people in day-to-day service work under these conditions. ${ }^{34}$

Nor will new programs be very different in a few years. With only a few exceptions the Corporation has used the formula devised for setting "minimal" levels to allocate funds as well. This means that most new programs are receiving seven dollars per poor person, based on the following calculations:

Number of cases per 10,000 poor persons

Number of lawyers needed

Cost for lawyers needed (including secretaries and paralegal assistance)

The unrealities in these figures are obvious. The number of potential cases in the poor population is probably well above the formula figure. ${ }^{35}$ The number of cases that could properly be handled by a lawyer and his or her support staff is at most a small fraction of this number. ${ }^{36}$ The costs of funding each lawyer, and his/her support (secretaries, etc.) are grossly understated. ${ }^{37}$

Services Corporation, Annual Report (1978). Most of the program improvement funds last year went into a five percent cost of service increase for programs. This, of course, is less than the annual inflation rate in the United States.

${ }^{34}$ There is still a good deal of controversy over the extent and desirability of turnover in the program. One estimate is that one out of every three lawyers leaves the program each year. The average level of experience is a little over two years. Sard, The Turnover Problem (unpublished memorandum, 1977).

35 The Corporation estimates that it is handling about 1.4 million of an estimated six million legal problems among the poor each year. Legal Services Corporation, Annual Report (1978). Experience in Boston indicates that estimates of "legal need" measured in problems per person are substantially understated. See Action Plan for Legal Rights (1975). C.f. P. Stolz, The Legal Needs of the Public - A Survey Analysis (Chicago, American Bar Foundation, 1968); Koos, The Family and the Law (unpublished monograph, 1949). For an excellent analysis of the problems involved in ascertaining need, see F. MARKs, THE Legal Needs of the Poor: A Critical Analysis (Chicago, American Bar Foundation, 1971).

${ }^{36}$ Most lawyers in private practice do not handle more than $50-75$ cases per year. See Carlin \& Howard, Legal Representation and Class Justice, 12 U.C.L.A. LAw REview 381, 417 (1965). The average caseload of a legal services lawyer in 1971 was 415 . Auerbach Corporation, Office of Legal Services Individual Project Evaluations, Final Report (Washington D. C., Office of Educational Opportunity, Office of Legal Services, 1971).

37 The incomes of legal services lawyers have generally averaged less than half the income of private practitioners. E. JoHnson, JR., supra note 6, at 100. 
In any part of the country receiving the designated allocation per poor person, there will be literally thousands of people who could not possibly be "served." It may have been that such an approach was the only way to have gotten more money and that "growth will beget growth." But it is certainly the case that the Corporation has put into place across the United States a very large number of seriously underfunded programs. Programs have, in turn, responded to scarcity in a variety of ways that have undercut their ability to maintain quality of service (i.e., reducing support staff, using large numbers of inexperienced people, etc.). Without more money, and without the political support to generate it, these responses will define the content and character of legal services in the United States in the next decades.

\section{B. The Strains of Practice}

The problem of inadequate resources takes on special importance as we begin to understand more fully the strains involved in actually providing legal services to the poor on a day-to-day basis.

These strains have two aspects. First, there is the relentless pressure of caseload. The increasing amount of regulation and law-governed activity in the United States makes the possible number of cases in any given poor population extremely large, if not unlimited. Every conflict in the family, at school, at work or with a vast array of governmental institutions has some legal aspect - that is, it is capable of being handled in whole or in part by a lawyer. Moreover, it is now reasonably well established that demand for legal services increases with supply. The more lawyers that are available the more clients that will seek their help. ${ }^{38}$ This combination of factors means that every office must cope with the uncomfortable choice of either being inundated with cases or dealing with the accompanying strain - not easily understood until one has done it - of regularly turning needy people away.

Second, there are the often self-imposed pressures to reduce the amount of care and energy given to any particular case. This is, to

38 This problem is discussed in more detail in Bellow \& Kettleson, From Ethics to Politics: Confronting Scarcity and Fairness in Public Interest Practice, 58 Boston University Law ReVIEW 3 (1978). 
some degree, simply a way for the lawyers to increase the number of cases they can handle. But, in many instances, the dynamics of "doing less for more" are more subtle than that. Because this is such a widespread phenomenon in legal services, it deserves some further elaboration.

The problem begins with a number of "givens" of legal aid practice: a) the complexity - legally and emotionally - of the problems with which the lawyers deal, $b$ ) the inevitable communication problems between lawyers and clients of different social backgrounds, $c$ ) the crisis character of so many of the cases, $d$ ) the impatience and occasional hostility of local judges, ${ }^{39} e$ ) the lack of standards and the absence of any review of performance, and $f$ the unavailability of experienced attorneys with whom to consult and work. Such a work situation is, at best, a difficult one. For most recently graduated lawyers - totally untrained in law school to do most of the basic tasks of practice and often unskilled at learning from experience in such situations - it is nearly impossible. The pressures on these attorneys, who make up the bulk of the program's staff, to take the path of least resistance - to convince clients and themselves that nothing much can be done for them, that additional research or investigation on the case is unnecessary, that the result they obtained was all that was possible - is very great indeed. The net result of these pressures is to induce patterns of practice throughout the legal aid system which depart substantially from norms of care and competence which I believe most program people would agree are reasonable to expect in legal services work. ${ }^{40}$

Unfortunately, current trends in the program only exacerbate

${ }^{39}$ It is one of the less acknowledged realities of the "rule of law" in the United States that its officials rarely intend to give full scope to legislatively declared mandates. Indeed, the gap between rules and their enforcement is so large that structural explanations seem far more persuasive than the suggestion that non-enforcement is merely "slippage" - an unintended departure from the ideal. C.f. R. Unger, LAw In Modern Societr (New York, Free Press, 1976); Klonoski \& Mendelsohn, The Allocation of Justice: A Political Approach, 14 Journal of Public Law 323 (1965).

40 This is a much more controverted statement than the text suggests. My own research, with Jeanne Kettleson, has involved looking at hundreds of legal services cases files (200 from members of the Bar, 500 from students doing legal aid work) and follow-ups on the case analysis with interviews and meetings with the students or lawyers involved. Some of our early conclusions are set out in Bellow, Turning Solutions Into Problems: The Legal Aid Experience, 1977 NLADA BriefCASE, No. 4. I have included in this paper a) two examples of the casework analysis we have been doing and what we have seen (Appendix A) and $b$ ) a memorandum that we have used to generate discussions of self-evaluation among legal services lawyers (Appendix B). I hope these will give the reader a clearer picture of the problems we are observing. 
both these problems. Salary structures pay no premium for developing competence in day-to-day office work. Attorneys who leave neighborhood work for a more interesting "law reform" practice generally receive not only higher pay, but also more status and better working conditions. New, inexperienced lawyers are quite literally dumped into situations in which most handle excessively large caseloads - sometimes as many as 75 to 100 pending cases - in their first weeks of work. Few resources are devoted to support staff and services at the neighborhood level. Stated simply, day-to-day service to clients is defined and organized in ways which make low quality of this type of work a self-fulfilling prophecy.

This is further complicated by two major aspects of existing national policy: deference to local autonomy and the commitment to access. The former makes it unlikely that there will be any significant evaluation or monitoring of what programs are actually doing. (For several years, programs even refused to provide the Corporation with aggregate statistics on their practice.) The latter makes it very difficult for local programs to spend resources on staff development or to concentrate on the general level of office proficiency and competency. Without a clearer and less quantative view of the long term, it is hard for staff to justify, even to themselves, the allocation of resources to their own needs. The same problems attend efforts to limit caseload, despite the amount of rhetoric that has emerged recently on the need for priority setting. Choosing among clients and cases requires a relatively sophisticated politics about what legal assistance can or should be attempting. Not only has there been too little discussion of such political questions in the program to develop any such working consensus, there has not been any experience with or legitimation of such an analysis. Programs are being asked to make essentially political decisions within the framework of an apolitical ideology.

Faced with large caseloads, staffed by inexperienced lawyers, and unwilling or unable to engage in long-term planning and staff development, offices, not surprisingly, slip into ad hoc approaches to accepting cases - indiscriminately opening and closing "intake" thereby only exacerbating their inability to respond systematically to the pressures they face. What is more surprising to me is how widespread the resulting patterns of inadequate service have already become. 


\section{The Trend Toward Insularity}

Difficult as these problems are, I would be less worried about them were it not for a third problem: the tendency within the system toward self-protectiveness and inflexibility. At the individual program level, this is a function of $a$ ) the lack of case supervision or monitoring in most offices, $b$ ) chaotic office procedures and recordkeeping, $c$ ) the unwillngness or inability of the more experienced attorneys in the program to provide benchmarks for good work in particular areas of practice, d) the lack of involvement of anyone other than staff attorneys (e.g., law teachers, private practitioners) in most programs, $e$ ) the large number of clients unable or unwilling to challenge their lawyers, and $f$ ) the degree to which legal service work is "invisible," i.e., done without co-counseling or consultation. Taken together, these features make it extremely easy to practice law in a legal services office without scrutiny of any kind. The absence of scrutiny, in turn, permits the lawyer's experience to take on a given, this-is-the-way-things-are quality. Patterns of belief (the judge will never grant such a motion) harden because confirmed by others with similar, albeit untested, beliefs. Explanations (the client did not want to sue, it would not have done any good anyway) gain plausibility because they are legitimated by a generally shared world view. Beliefs and explanations guide actions and create their own self-justification. The offices become a closed environment surprisingly resistant to new possibilities and new ways of doing and thinking about things.

An analogous process seems to be operating at the national level of the program as well. Insularity here, however, is a function of a complex accommodation that seems to have been worked out between the Corporation's staff and organized interests within the program, more particularly the Project Advisory Group (made up of representatives from the programs) and the National Client's Council (made up of representatives of clients from local programs) (I will call these internal lobbying groups: ILG's). The elements of this accommodation with the Corporation look something like this:

- The Corporation is generally supported by the ILG's in its efforts to get more funds for legal services.

- The Corporation is also assisted by the ILG's in controlling (or attempting to control) efforts of individual programs to get spe- 
cial privileges for themselves from the Corporation or to deal directly with Congress.

- In return, representatives of the ILG's have ready access to Corporation staff and regularly participate in the formation of Corporation policy.

- New funds are allocated in accordance with pre-established formulas so that competition among programs can be kept to a minimum.

- Policies follow relatively established and predictable lines. New initiatives require extensive (and sometimes endless) debate and participation throughout the "legal services community."

- ILG's receive Corporation funds to meet and otherwise carry out their activity.

- There is, and will continue to be, little Corporation scrutiny of the actual performance of programs.

- The ILG's are left to put such pressure on their "peer" programs as they deem appropriate.

This is a complicated subject, and it really is impossible to do it justice in this brief report. There are many important values in such participatory structures, and I do not want to imply bad faith or a conspiracy among Corporation staff and the ILG's. Nor do I want to suggest that there is not a good deal of open debate within the legal services system. However, there are certainly elements here of "capture" of the regulator by the regulated.

Severe limits on discretionary funding decisions prevent experimentation within the system. Presumptions in favor of existing models of service undermine thoughtful consideration of alternatives. Participatory structures which do not encourage new participants become, over time, increasingly hard to penetrate. Although the policies of the Corporation seem the product of debate and compromise, they have often been less the result of considered alternatives than the consequence of a process of decision which has been insulated from dissident views. This includes, I believe, decisions concerning a) judicare models, ${ }^{41}$ b) expansion, c) differential

41 This is an especially good example. I believe that insularity has been an important factor in the overwhelming resistance within the program to judicare. It is hard to imagine an adequate system of legal services in a country as dispersed and large as the United States without much greater involvement of the private bar. See, e.g., Johnson, in M. CappelletTI, J. Gordley \& E. Johnson, Jr., Toward Equal Justice: A Comparative Study of Legal Aid In Modern Societies 235-36 (Dobbs Ferry, N. Y./Milan, Oceana/Giuffrè, 1975) (dis- 
funding of existing programs, $d$ ) internal salary structures, and e) project evaluation, to name only a few. How these decisions have been made, and are likely to be made in the future, may be the most serious problem those concerned with legal aid in the United States will have to face.

\section{Some Concluding Remarks}

The foregoing was written while I was and am engaged in day-today legal services work in a low income area in Boston. If our office can make peace with the crush of cases and crises that confound efforts of this nature, we plan to create a school for entering legal services lawyers, which we hope will be part of a network of trainingpractice centers throughout the legal services system. ${ }^{42}$ It is from this perspective that I would like to add a few more personal observations to what I have already said here.

\section{A. The "Delivery" Problem}

Even a cursory glance at the numbers makes the ideal of "enough" lawyers for poor people a chimera. As has been said elsewhere, ${ }^{43}$ given the number of only the officially-acknowledged poverty stricken in the United States, such a goal would require increases in the size of the legal profession which could not be justified even by the most ardent advocates of more lawyers for the poor.

On the other hand, there are literally thousands of poor people whose lives would be made somewhat easier and less vulnerable if they had a clearer sense of what were legally protected grievances, more knowledge of ways of pursuing them, higher expectations about what was possible to achieve through asserting claims in the existing system, and the availability of responsive forums and competent representation if they needed them.

Perhaps more important, there are - in overwhelming numbers

cussing the advantages of a client option mixed system). The proponents of judicare may be unfair to Mr. Johnson, but they do not misread the strong opposition to serious consideration of judicare models within the legal services community.

42 The Legal Services Institute: A Proposal to the Legal Services Corporation (1978).

43 Bellow \& Kettleson, supra note 38. 
in a society as stratified as is the United States - the daily calls of individuals for help and for what has been aptly described as corrective justice. ${ }^{44}$ The "delivery" problem is not simply an issue of supply and demand. It is a problem of the kind of relationship that those with some power have with those with less. It is to the credit of those who work in the legal services system - and take as many cases as they do - that this question is not lightly ignored.

Faced with these realities, I find myself more and more interested in efforts to decrease the centrality of lawyers - or, at least, lawyers playing traditional roles - in the legal aid system. A large (very large) increase in a) paid, community-based lay advocates, $b$ ) "pro se clerks" and other persons (in a variety of agencies) whose job it is to facilitate either negotiation or adjudication without lawyers, $c$ ) the number of forums in which the unrepresented or those represented by lay persons would find a responsive setting, $d$ ) the training and commitment of lawyers to perform support roles as a back-up to self-help lay advocacy efforts, $e$ ) systems which regularize the handling of particular kinds of cases, and $f$ ) public education (much earlier and more extensive than currently exists) designed to increase law knowledge and sophistication, would, I believe, make some dent in the ways the current system excludes and channels grievances. It might also permit a much more serious debate than we have yet been willing to have on the nature of legal "expertise," the functions of legal training, and the role played by the legal profession and professionalism in law in perpetuating the problems they have now publicly undertaken to solve.

\section{B. The "Reform" Problem}

None of these changes would, of course, radically alter the influence of wealth and power on outcomes. No reform of the legal system is unaffected by the realities of the extralegal environment, no matter how we attempt to obscure it. The best that can be said for efforts to achieve the "internal" reforms I have mentioned is that a) they may lay some groundwork - in expectations, confidence and skill - among the people we serve that will add to their willingness

44 Discussed in Hazard, Social Justice Through Civil Justice, 36 UnIversity of Chicago LAW REVIEW 699 (1969).

6. 
and ability to participate in larger change efforts, and $b$ ) they may direct attention to what I believe is an important element of a just legal system - regulation of the fees and activity of the legal profession itself.

For me - particularly as I work with and for poor people however, these goals simply cannot be enough. There is potential, in day-to-day legal services work, to affect the communities, neighborhoods and institutional environments in which the poor live and work. Many of us feel that it is a potential that has never been adequately realized by individual offices, either in the sixties or the seventies.

There is, of course, no law-engineered revolution on the horizon in the United States, and no need for extreme rhetoric or excessive romanticism. But in the U.S. (I do not know about elsewhere) a confluence of factors makes it possible for legal services offices to a) stimulate, protect and enhance political organization and mobilization, $b$ ) aggregate the impact of individual claims, and $c$ ) exert influence in favor of changes that affect large numbers of clients. Without minimizing the difficulties and complexities involved, it seems enough for me that, because we can, we must.

The dilemmas in pursuing either reform or increased service are obvious. Neither is likely to generate much potential political support for efforts that will inevitably produce considerable controversy. Both are extremely difficult to carry out, particularly in the face of the pressures and strains I have described. The problem of attempting to reconcile both approaches in a single office - despite the many ways they reinforce each other - are enormous.

Nevertheless, I hope, and I speak here more to legal services workers than to participants in this conference, that we will try. Reform efforts on behalf of the poor that are not grounded in an understanding of their lives and strengths are too often irrelevant, narrow or counterproductive. Day-to-day work which ignores systemic issues or standards of quality becomes, at best, shallow and, at worst, another form of support for the status quo. Ironically, most neighborhood legal services offices in the U. S. neither organize their work to increase volume nor discipline it to maximize impact. Rather, they drift in an atmosphere of detached processing of clients not unlike that behavior of teachers, social workers, and government administrators about which so many of us have often complained.

My own judgment is that it can and should be otherwise. 


\section{APPENDIX A*}

The following are two "cases" which are fairly typical of the sort of representation being afforded to poor clients in legal aid offices. They were selected from a larger sample of over eighty such cases handled by legal aid offices in a number of cities and counties in the last two years. The lefthand column is intended to give the reader some background information on the relevant legal and tactical possibilities available to counsel. Hopefully, this mode of presentation will provide some insight into what "might have been" in these relationships between clients and their attorneys.

\section{CASE 1}

At the time Mrs. L came into the legal services office, she had been divorced a year and was living with her five-year-old daughter in an appartment in a low-income area of a midwestern city. Five other families lived in the building, and all apartments were subject to the city rent control law and the state sanitary code.

The previous winter the oil burner had broken down and the tenants had been without heat for weeks at a time. The building was also in serious disrepair (exposed wiring, peeling paint, sagging ceilings), and a number of tenants, including Mrs. L, had refused to pay rent for two months. Later she fell an additional month behind.

Two months before Mrs. L came to the office, Realty Trust, the owner, had hired a new management company to maintain the building. The company had made substantial repairs and had indicated to all tenants that it planned to pursue the back rent and to seek an increase from the rent control board to cover the cost of rehabilitation. It followed this up by serving eviction notices on a number of tenants who were in arrears. Sometime shortly before she came to the office, Mrs. L received a summons and complaint informing her of eviction proceedings against her.

* Taken from 1977 NLADA BRIEFCASE 123-25. 


\section{Observations}

Although faced with a possible eviction, Mrs. L had a good many legal claims and defenses available to her under the law of the state in which she lived. These included a) a claim for damages or for back rent because of the condition of the premises (the conditions were bad enough to violate local housing and sanitary codes); $b$ ) a defense to the eviction on the same grounds; $c$ ) a defense to the eviction on the grounds that the landlord was proceeding against Mrs. L because of her prior withholding of rent. Although the lawyer never learned of it, only certain tenants in arrears, considered by the new management company to be potential "trouble-makers," had received eviction notices.

In addition, Mrs. $\mathrm{L}$ was entitled to certain procedural safeguards in any action against her. It was later learned that she had never been correctly served with the court papers. This possibility was not explored by the lawyer in the course of the interview, nor did the lawyer subsequently investigate the past or present conditions in the building, or the possibility that the eviction had been improperly motivated. The lawyers always assumed that Mrs. L didn't pay three months' rent simply because she couldn't afford it and that the eviction was a consequence of her failure to pay.

Interestingly, two other tenants in the building were clients of other attorneys in the office, although none of them were aware of this. None of these issues were ever discussed with any of the clients.

The call should have been preceded by some planning about what demands to make and what counterdemands might be acceptable. It also should have been based on a good deal of knowledge about the case, the applicable law, and Mrs. L. The conversation with the building manager might have been very different if the lawyer had been able to answer the

\section{Counsel's File Entries}

September 10. Spoke with Mrs. L who brought in eviction papers that had been served on her. Said that she had been in the building for two years and wanted to stay but didn't have enough money to pay the three months' back rent. I told her I would call the landlord to see what I could work out. The building is apparently in very bad shape.

September 12. Called counsel for Realty Trust and was referred to the building manager. The manager said that anything wrong with the building had now been corrected and was not his responsibility. Mrs. L was a problem tenant whom he suspected of being on drugs, he wanted her out as soon as possible and would agree to no negotiated resolution. 
assertions about his client and had argued forcefully that, given the conditions in the building, Mrs. L did not owe the landlord any rent and could not be evicted. (This, in fact, would have been a fair interpretation of the law.)

The manager might also have responded very differently had the lawyer discussed with him the likely effect of the prior violations in the building on the company's efforts to obtain a rent increase from the rent control board or the potential claims for damages that the other tenants in the building had against the owner.

By not taking a strong position in the first contact with the manager, counsel for Mrs. L may well have given the impression that the manager's views of Mrs. L were justified and that her lawyer did not intend to pursue the case aggressively.

As the lawyer indicated in an interview after the case was completed, he never did enough legal or factual research to be confident of his position and was unsure whether the fact that the new company had not been involved in the past deterioration of the premises significantly affected his position. Under the prevailing law, it did not.

By failing to have checked more carefully when and how Mrs. L received the papers (by a call to the marshal who served them or by pressing the clerk about the due date) the lawyer ran the risk of missing an important deadline date. In fact, the clerk was in error; the answer was due on the $17 \mathrm{th}$, although the landlord's lawyer apparently didn't try to take advantage of its being filed late. More significantly, the lawyer did not a) check with the rent control board to be sure the rental level was proper; $b$ ) ask for an inspection of the premises by the appropriate government agency; c) seek formal disclosure by Realty Trust or the management company of what repairs were made on the building, or of any communications, documents, and the like relevant to the
September 17. Called the clerk of the court and learned that the answer was due tomorrow. Filled out a regular form answer defending on the grounds that conditions in the building violate the state sanitary code. Trial date is late next week. 
eviction of Mrs. L; d) discuss any of these possibilities with his client. The answer was also not carefully drafted, omitted a number of available defenses (including a possible action for damages), and could only signal to the opposing counsel that Mrs. L's case was being handled as a routine matter.

Mrs. L might have needed a babysitter or help in getting to court, as well as some idea of what would happen there. None of these possibilities was considered by the lawyer, nor did he counsel Mrs. L about her forthcoming testimony. Other potential witnesses were not sought. There is no way the case could have been properly presented to a court on the basis of the preparation that had been done up to this point in the process.

The lawyer did not ask why Mrs. L's daughter needed medical attention. It turned out that the child had a number of medical and school problems with potential legal remedies that were never explored. In reviewing the case after its completion it was also found that Mrs. L had made payment on a consumer purchase that she could have legally avoided and was receiving $\$ 50$ less welfare than she was entitled to while the eviction case was being handled. The lawyer was never aware of these problems.

In addition, he was careless in asking for a continuance without notifying the other side in advance and getting an affidavit or other documentation from Mrs. L that established the legitimacy of her inability to attend. As a result, the judge refused to set a new date and required a trial that afternoon.

Why Mrs. L accepted the settlement is not known because of the minimal exploration of her desires and options. Similarly, without investigating the apartment's condition, past and present, it is impossible to know whether the settlement was warranted. Given the
September 20. Wrote to client to tell her to be in court on September 24 .

September 22. Mrs. L called to tell me she couldn't make the hearing on the morning of the 24th because she had to take her daughter to the doctor. I told her I'd ask for a continuance of the case but that if it wasn't granted, she'd have to come in that afternoon.

September 24. Called Mrs. L from court to tell her that the case was set for 2 p.m. this afternoon, but that the landlord's lawyer had agreed to give up two month's back rent if she'd pay last month's rent, stay current, and leave within 90 days. I told her that since sev- 
possible defenses and actions against the landlord, however, and the admission by the building manager that a good deal of repair had been undertaken, what Mrs. L agreed to was probably far too generous. eral hundred dollars was being forgiven, it was a pretty good deal and about the best I could do. She authorized me to accept it.

\section{CASE 2}

At the time this case came into the local legal services offices, Robert C, age 13 , was living with his five brothers and sisters and his mother in a public housing project in a large eastern city. His mother spoke no English, and he was reading only at a second grade level. For the last four years, the schools had considered him to have "language problems". Last year, he had been tested under a new program established under the State's Special Education Law and found to be suffering from a specific learning disability. His mother had been advised that he would be sent to a special education program in the fall; (he was entitled to this under the law). At the beginning of school, however, no such arrangements had been made.

\section{Observations}

The case arises several weeks after school has started. Counsel does not ask about Robert's current situation, what he will do while the placement is being arranged, or what the specifics of Robert's problem are. Nor does she initiate any discussion with his mother about the educational program that is planned for him. By law in the state, all school records relating to a child's needs and education can be obtained by a parent or authorized representative. Counsel makes no attempt to do this.

Counsel knows that her client does not read English. She does not ask if the forms are also in Spanish (they are not). Nor does she determine the precise nature of the mix-up or act to hasten the process.

Again counsel is willing to permit someone other than her client to define the pace and content of the events. In the course of these contacts, Robert will miss close to two months of schooling.

\section{Counsel's File Entries}

September 27. Mrs. C came in today with her social worker (who acted as translator) to ask for help in getting her son into a school. I got the necessary background facts and told her that I would get back to her. Mrs. C seems quite willing to go along with any special program the school officials suggested, but believes he should be in school.

October 4. Called the responsible official and she said that there was a mix-up in processing the papers which had been sent to Mrs. C. Said I should call back in a week.

October 11. Called back and learned that the problem is transportation. Forms will be sent out to Mrs. C today. 
Counsel does not make any effort to get the schools to change the forms so that other students are not similarly prejudiced. If she had researched it, she would have found a state statute requiring bi-lingual communications in all such circumstances. The statute is enforceable through court action.

In exploring this case after these events, it was determined that a) two of Robert's brothers and sisters also had severe learning disabilities and were entitled to help under State law; $b$ ) the family was not receiving the amount of welfare and food stamps to which it was entitled; $c$ ) Robert had been placed in a program which the psychologist at his former school considered detrimental for him. Counsel never explored any of these issues with her client. Indeed, it turned out that she didn't even know how to calculate benefits under the food stamp program. She also did not feel any obligation to monitor the situation to be sure that Robert was in fact fully receiving the educational services to which he's entitled. This would have involved checking to see that Robert was receiving free lunches and breakfasts (provided for under existing program), that no fees were being charged him that prevent his participation in school activities and that his school records do not "mislabel" him.

There is a growing body of law governing the legal aspects of suspensions from school. Counsel thus has available a number of legal theories to seek expungement of prior suspensions or prevent future ones if the school acted improperly or without a proper basis for disciplinary action. For example, there is some question whether, under the applicable state law, a child found to have special educational needs can be excluded from school when other alternatives were available. No research into these issues was ever undertaken. More important, she might have tried to ascertain what was causing Robert's conduct and to explore with school per-
October 19. Called school. Forms have not been returned. I informed them that Mrs. C does not speak or read English and learned that the forms are not written in any other language. The forms will be sent to Mrs. C through her social worker.

October 25. Called school again, learned that forms had been returned. Robert will be in school tomorrow in a special program for bi-lingual children.

October 28. Called school and Robert is in fact attending. Will write a letter to Mrs. C telling her that I am closing the case.

November 13. Mrs. C's social worker called to tell me that Robert had been suspended from school several times and to ask if anything could be done about it. I called the school and found out that he'd been continuously wandering the halls without a pass and had refused to sit in his seat. He was now back in school. I called the social worker and let her know. 
sonnel better ways of coping with it. At no time does she ever meet directly with Robert or have any personal contact with him.

Counsel again ignores a questionable school practice - the use of juvenile court referral to maintain discipline in the schools. No consideration is given to contacting appointed counsel or (with the client's consent) sharing some of the foregoing facts, many of which would be helpful to counsel in properly presenting Robert's case in the Juvenile Court. On the other hand, counsel has had so little contact with the family it is questionable whether she could now be of much help.
December 5. Mrs. C's social worker called to inform me that Robert had been in a fight at school and had been referred to the Juvenile Court. He'd also been arrested earlier in the month for shoplifting and had been brought before the same court. I told him that they would appoint counsel for him. 


\section{APPENDIX B}

MEMORANDUM

Harvard Law School

Cambridge, Massachusetts

September 29, 1977

From: Jeanne Kettleson

Re: Background for September 30, 1977 Case Review Training Session

\section{INTRODUCTION}

In our review of over one hundred legal services cases and 300-400 cases handled by students in the clinical program, we've observed patterns of case handling that are remarkably consistent across attorneys and offices. The following is an attempt to summarize the patterns we're seeing, and to contrast them to what we would consider good patterns of practice.

I've called the patterns we are seeing "passive/stereotyped," and the patterns we prefer "active/creative." These patterns are organized by stages in the development of a case that would be relevant whatever the particular legal issue involved (housing, employment, consumer, welfare). We don't yet have any adequate explanation of the causes of the behavior we're seeing, but we do find correlations between these patterns and outcomes in particular cases. The "passive/stereotyped" behaviors we observe correlate with what we consider to be minimal to unsatisfactory outcomes, while the "active/creative" patterns are associated with satisfactory to maximal outcomes.

There are, of course, a number of problems with attempting to make judgment about the quality of lawyer work. "Good" lawyering and "maximal" results are, in the end, indeterminate, relative, and subjective. Nevertheless, at the extremes one can point to clear differences in the way similar cases are handled, and evaluate outcomes in terms that seem to us and the lawyers with whom we've been working meaningful and persuasive.

Overall, the following seems to capture and explain, more accurately than we might have thought, what we're seeing. That may be only because we've seen so many examples that our categories take on a meaning for us that the label itself doesn't convey. Therefore, examples are included and, in discussing the case studies with you, we will work within the framework of these categories. 


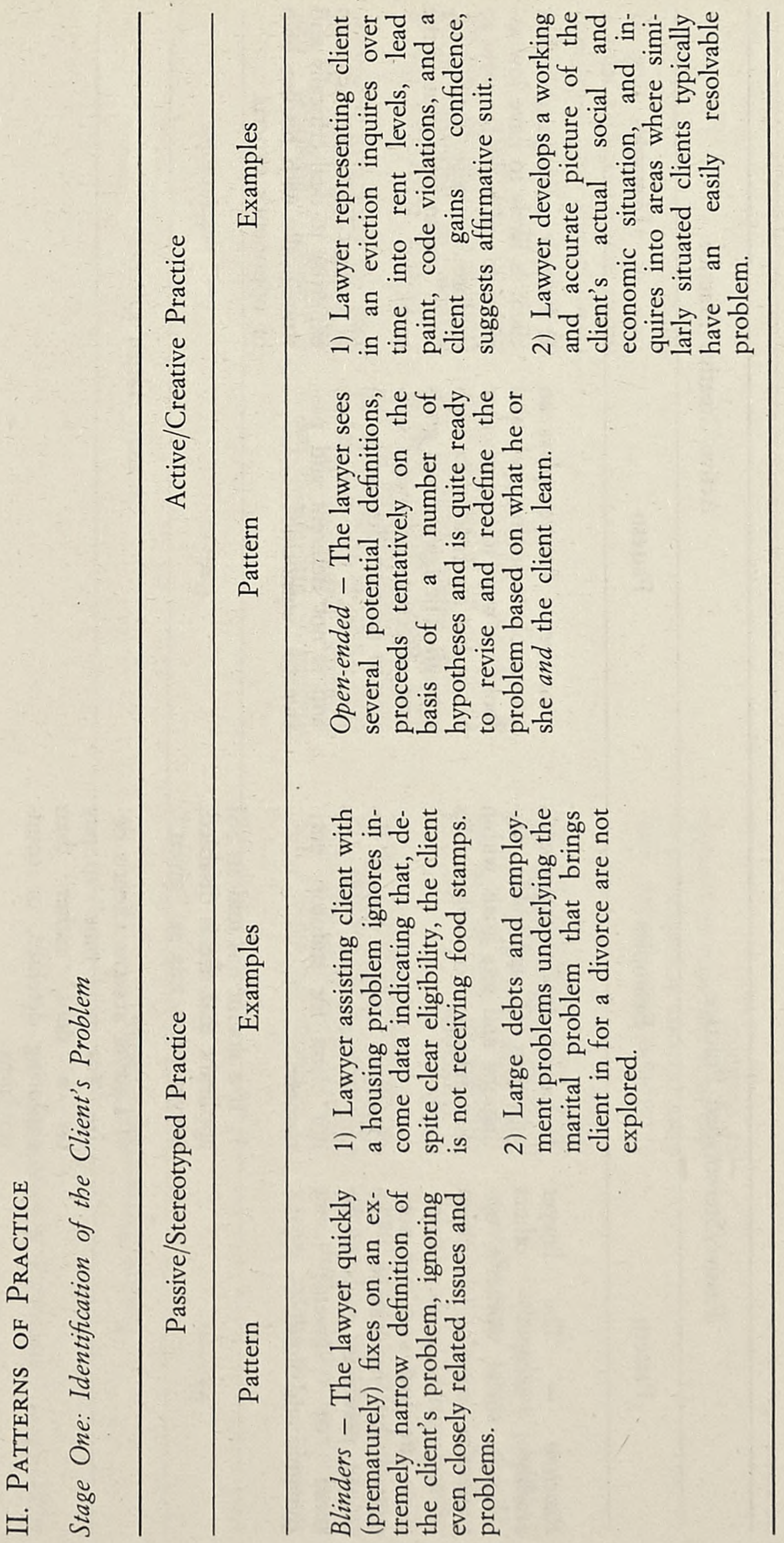




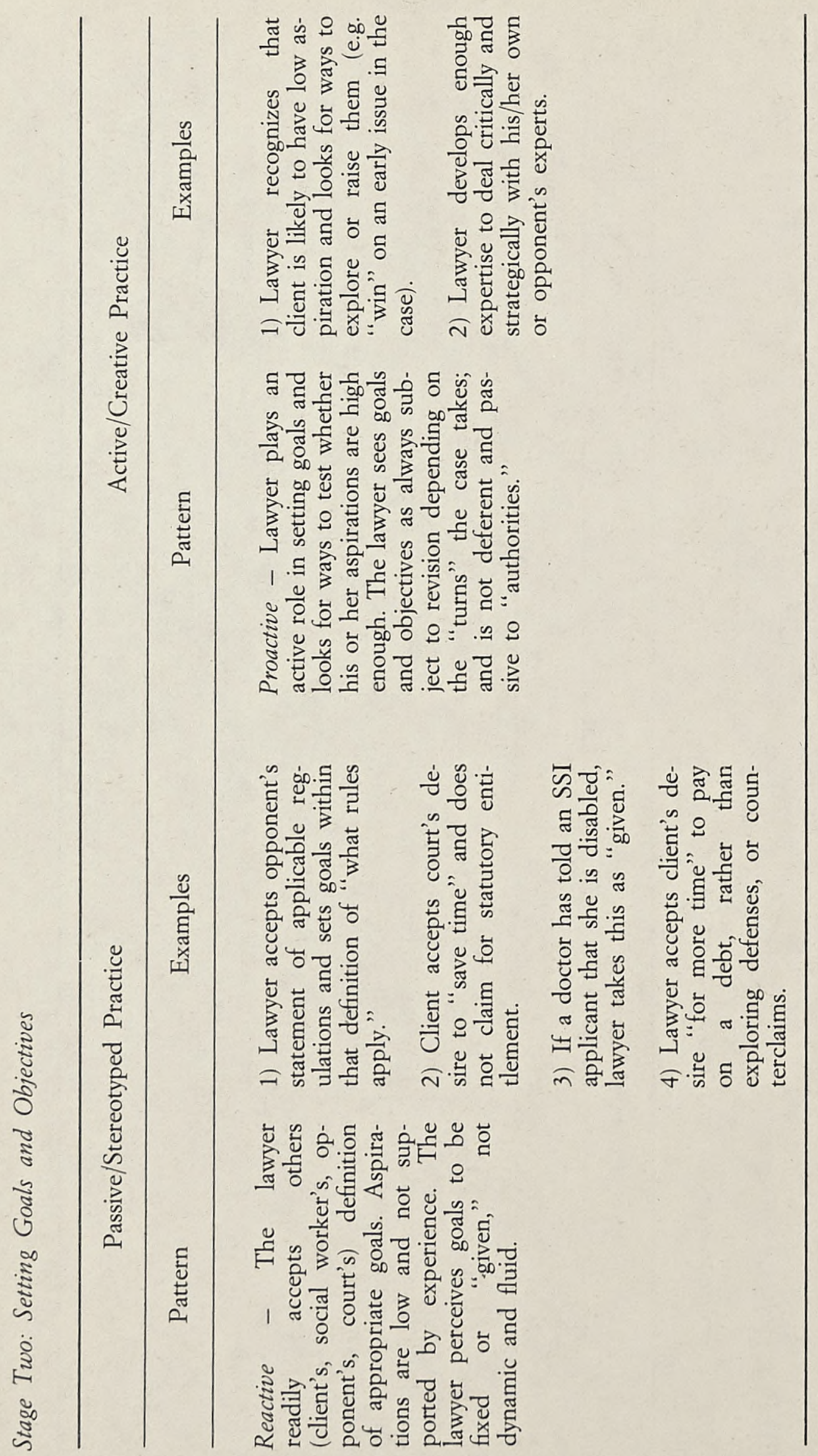









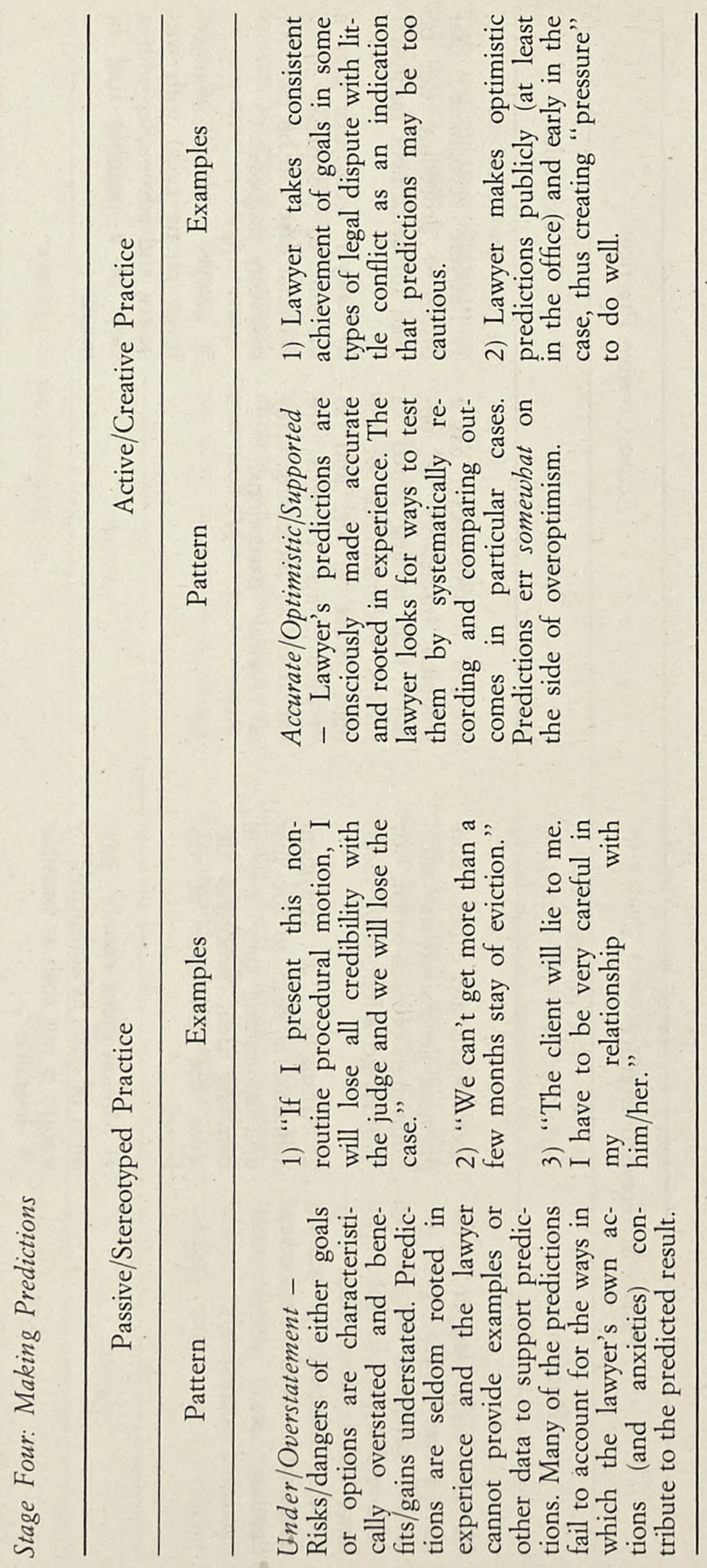




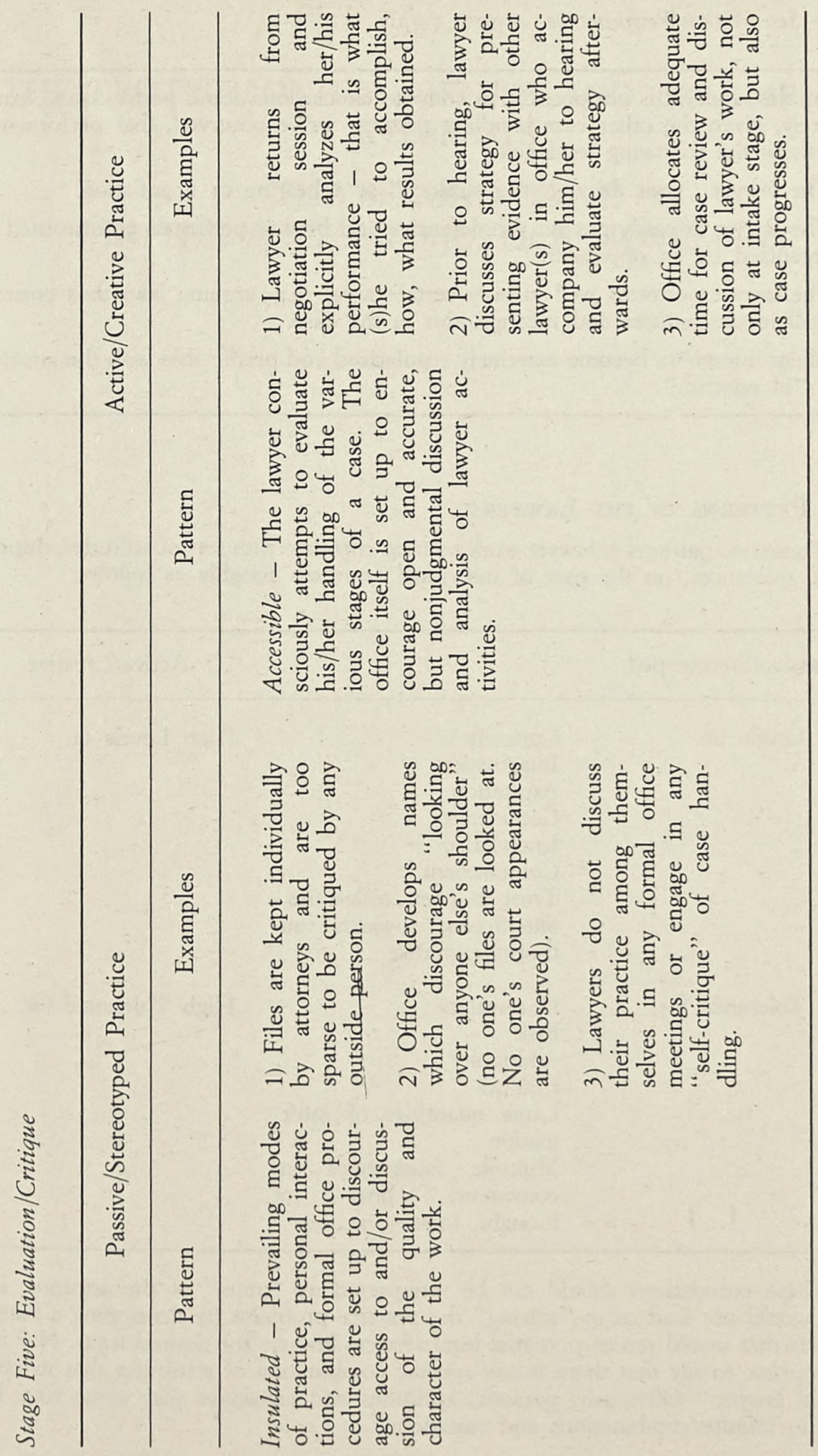


From files alone, it is not possible to come to conclusions about performance, but it is likely, given the other case handling patterns we've observed, that performance will show the following tendencies:

1) The lawyer "goes through the motions" at a hearing or negotiation.

2) The lawyer is easily put on the defensive and his/her performance disrupted or disorganized by an opponent.

3) The lawyer performs well in only certain areas (e.g. arguing law) thus creating over-all inconsistencies and incongruities in the case.

4) Client interviews become extremely regularized and predictable with the attorney fully "in control."

\section{Patterns in the LAwyers}

These two patterns of lawyer work seem to correlate with sets of attitudes, dispositions, tolerances, on the part of individual attorneys roughly as follows:

\begin{tabular}{|c|c|c|}
\hline Passive/Stereotyped & & Active/Creative \\
\hline Low Levels of: & $\begin{array}{l}\text { Curiosity } \\
\text { Imagination } \\
\text { Aspiration } \\
\text { Confidence } \\
\text { Knowledge } \\
\text { Commitment } \\
\text { Trust in peers/colleagues } \\
\text { Skepticism towards au- } \\
\text { thority/expertise }\end{array}$ & High Levels of: \\
\hline Low Tolerance for: & $\begin{array}{l}\text { Uncertainty } \\
\text { Risk } \\
\text { Ambiguity } \\
\text { Conflict } \\
\text { Large quantities of infor- } \\
\text { mation } \\
\text { Multiple (sometimes in- } \\
\text { consistent) lines of } \\
\text { thought, inquiry, action }\end{array}$ & High Tolerance for: \\
\hline
\end{tabular}

These correlations should not be interpreted as "traits" of the attorney, and they would not lead us to "solving" the practice problems by developing a battery of tests that would screen potential legal services lawyers for desired traits. Nor is it appropriate to say that there is any specific combination of attributes that makes a "good lawyer." Obviously, personal aptitudes and capacities play some role, but only in infinite combinations and variations. 
PART TWO

THE PROTECTION OF DIFFUSE AND FRAGMENTED INTERESTS

THE SECOND WAVE

IN THE ACCESS-TO-JUSTICE MOVEMENT 


\title{
PUBLIC INTEREST LITIGATION: A COMPARATIVE SURVEY
}

\author{
by \\ HEIN KÖTZ \\ Co-Director, Max-Planck-Institute, Hamburg
}

\section{INTRODUCTION ${ }^{1}$}

Most comparative lawyers would agree that the recent growth of private actions instituted by private parties for the protection of the public interest is one of the most significant developments in contemporary civil procedure. It is indeed arguable that this development will lead to far-reaching changes in the style and nature of civil litigation. Traditionally, civil adjudication has been understood to be a process for resolving disputes among private parties about private rights. On the other hand, the new type of civil litigation with which we are concerned here is characterized by the plaintiff's attempt not only to vindicate his own rights, which often are minor, but also to redress injuries to the "diffuse and fragmented interests" of a broad

1 While there is a wealth of literature analyzing devices for representing public and group interests in civil litigation on a national basis, comparative work in this field is relatively rare. The principal articles (as adapted from earlier versions) are Cappelletti, Governmental and Private Advocates for the Public Interest in Civil Litigation: A Comparative Study, in Access To Justice: Promising Institutions 767 (Alphen aan den Rijn/Milan, Sijthoff and Noordhoff/Giuffrè, Vol: II of the Florence Access-to-Justice Project Series, M. Cappelletti \& J. Weisner eds., 1979) (with copious references); and Cappelletti, Vindicating the Public Interest Through the Courts: A Comparativist's Contribution, in Access to Justice: Emerging Issues and Perspectives 513 (Vol. III of the Florence Access-to-Justice Project Series, M. Cappelletti \& B. Garth eds., 1979). See also the interesting and well-documented article by Fisch, European Analogues to the Class Action: Group Action in France and Germany, 27 American Journal of Comparative Law 51 (1979). A comparative discussion of the problem with emphasis on environmental protection is to be found in E. REHBINDER, H. BURGBACHER \& R. KNIEPER, BÜRGERKLAGE IM UMweltRECHT (Berlin, Erich Schmidt, 1972). Bilateral studies comparing the position in the United States and the Federal Republic of Germany are Kötz, Klagen Privater im öffentlichen Interesse, in A. Homburger \& H. Kötz, Klagen Privater im ÖFfentlichen Interesse 69 (Frankfurt, Metzner, Arbeiten zur Rechtsvergleichung No. 69, 1975); and H. КосH, Kollektiver Rechtsschutz im Zivilprozess. Die class aCtion DES aMerikanischen Rechts UND DEUTSCHe Reformprobleme (Frankfurt, Metzner, Arbeiten zur Rechtsvergleichung No. 83, 1976). 
class of persons similarly situated - injuries which might be quite extensive when viewed collectively. In other words, the subject matter of the lawsuit is no longer a dispute between private individuals about private rights, but a grievance about the operation of public policy.

Arguably, however, the distinction between "traditional" litigation and "public interest" litigation is more illusory than real. An individual who sues either for damages because of the defendant's breach of contract or for an injunction to prevent the defendant from illegally interfering with the plaintiff's business is motivated solely by his desire to protect his personal rights. Even in these cases, however, bringing the action may be said to be in the public interest. A plaintiff who is awarded a judgment for damages or an injunction demonstrates to the public that breaking a contractual promise or engaging in illegal conduct will not go unpunished by the courts. For this reason even instituting civil litigation in the traditional sense may be said to be in the public interest. Indeed, the German legal scholar Rudolf von Thering wrote a book in 1872 in which he argued that it was unsatisfactory if individuals whose rights had been unlawfully invaded decided solely on the basis of their personal cost-benefit analysis whether to seek legal redress. Instead, Ihering believed the individual to be under a duty to institute litigation, because there was also a public interest to be taken into consideration, namely, the public interest in demonstrating the effectiveness of the law and in deterring potential lawbreakers from engaging in unlawful conduct. ${ }^{2}$

If this analysis is correct and plaintiffs even in traditional litigation are acting to some extent as representatives of the public interest, then the question arises as to what is meant by private actions in the public interest in the context of this paper.

In many fields of law there is no special need to stimulate private actions since there is no lack of individuals seeking to enforce their rights. Accordingly, no additional measures need to be taken in these fields to encourage individuals to seek legal redress in the courts and thereby to demonstrate the effectiveness of the law and the deterrent

2 See R. v. Ihering, Der Kampf um's Recht 49 (Vienna, Manz'sche, 10th ed., 1889):

Das allgemeine Interesse, welches sich an die Rechtsverfolgung durch den Einzelnen knüpft, ist nicht bloss das ideale, dass die Autorität und Majestät des Gesetzes sich behaupte, sondern es ist das sebr reale, böchst praktische, welches jedem füblbar wird und das jeder begreift ... nämlich dies, dass die feste Ordnung des Verkebrslebens, an der jeder zu seinem Teil interessiert ist, gesichert und aufrechterhalten werde. 
effects of the sanctions provided. In other fields, however, private litigation as a means of policing illegal conduct is rare or non-existent. Generally, in these fields numerous rules define illegal conduct and impose sanctions on violators; but there are no plaintiffs who are prepared to avail themselves of these rules.

There are various reasons for the lack of private litigants in these fields. For instance, the injury may be of a type which affects the interests of many people simultaneously but where the individual injury is so small that there is no point in seeking redress, or the injury may typically affect people who are too poor to pay for the expenses of litigation but nevertheless are too "rich" to qualify for legal aid, if legal aid is available at all. Even in cases where legal aid and legal advice are available, the persons affected may belong to population groups who lack the linguistic and other skills required to make use of the existing procedures. In other cases, potential plaintiffs will be discouraged from instituting litigation because the injury involves immensely complex facts and intricate law, for which redress is likely to involve an expense totally disproportionate to the size of the individual's claim. Furthermore, the defendant's interest at stake may be much larger than the individual plaintiff's. If, for instance, a large cement plant is emitting smoke in quantities exceeding the statutory limit, there may be individual homeowners in the neighborhood who have standing to bring an action. These homeowners, however, may refrain from suing because they feel that the resources available to the company to defend the action are so much vaster than their own that it would be foolish to embark on litigation. In cases involving air pollution there may be a diffuse group of other people likely to be harmed in some way. But the law may deny them standing to sue, the transaction costs necessary to pool their resources may be prohibitive, and there may also be a free rider problem. The result is that in many fields the reliance placed on the policing function of private litigation is unjustified because modern society increasingly exposes its citizens to group injuries for which they as individuals are in a poor position to invoke judicial controls.

Let us speculate for a moment on the reasons why the problem of providing protection against group injuries seems to have emerged as a major policy issue only in recent years. I think various reasons can be pointed out. One of these is that in the densely populated countries of the Northern Hemisphere individuals depend to a 
growing extent, because of an ever-increasing division of labor, on numerous public and private providers of goods and services. The process of economic concentration has led to the emergence of large productive units each of which employs thousands of people and provides goods and services to a vast number of individuals. Accordingly, decisions made by these units tend to affect large groups of people simultaneously. As stated by Professor Cappelletti,

more and more frequently the complexity of modern societies generates situations in which a single human action can be beneficial or prejudicial to large numbers of people, thus making entirely inadequate the traditional scheme of litigation as merely a two-party affair. For example, false information divulged by large corporations may cause injury to all who buy shares in that corporation; an antitrust violation may damage all who are affected by the unfair competition; the infringement by an employer of a collective labor agreement violates the rights of all his employees; the imposition of an unconstitutional tax or the illegal discontinuance of a social benefit may be detrimental to large communities of citizens; the discharge of waste into a lake or river harms all who want to enjoy its clean waters; defective or unhealthy packaging may cause damage to all consumers of these goods. The possibility of such mass injuries represents a characteristic feature of our epoch. ${ }^{3}$

On the other hand, in the modern welfare state it has been recognized that the groups and persons affected by such decisions deserve protection. Many critics believe that the protection provided is unsatisfactory, incomplete, and haphazard. Undeniably, in some of the politically visible areas of general concern, such as in the fields of securities regulation, consumer protection, or environmental protection, some action has been taken in the past years: regulatory agencies have been set up, rights have been created, statutory and judicial remedies have been granted. What has been overlooked, however, is that in many cases the individuals making up the group are in no position to act for themselves, even though they have a legal cause of action. The obstacle is their lack of knowledge and the disparity between the expense of seeking redress and their individual stake in the controversy. Consequently, it is no exaggeration to say that a major problem in the contemporary administration of justice is presented by the need to fashion an effective group remedy which will

3 Cappelletti, Vindicating the Public Interest, supra note 1, at 519. 
not only afford relief against group injuries but will also deter their commission and thus implement the public interest.

The purpose of this report is to describe legal techniques and devices used in various countries which serve the public interest by providing more effective remedies to redress group wrongs through the courts. Accordingly, I am not concerned with governmental programs seeking to make the courts more accessible to the poor. To be sure, the techniques and devices which are of interest in the context of this paper are intended to stimulate private actions, but their purpose is not to help indigent claimants but to promote the public interest. By instituting litigation, the claimant is promoting the public interest in having judicial controls applied to a field where otherwise certain types of behavior would remain unchallenged. The claimants typically activated by the devices at which we are looking will sometimes have incomes below the official poverty level. But this is not the rule. On the contrary, one can argue that the techniques we have in mind will often have little obvious benefit for the really indigent. Stimulating lawsuits by consumers, wildlife lovers, and deceived shareholders will typically benefit middle class interests rather than the interest of the citizens below the poverty line.

\section{Monetary Incentives}

\section{A. Multiple Damages}

The awarding of multiple damages is a device used in the United States to encourage individuals to seek judicial relief, thereby implementing a policy considered of special priority by the legislature. This is especially important in cases involving injuries arising from the violation of antitrust law. Under sec. 4 of the Clayton Act of $1914,{ }^{4}$ any person who has suffered injury to his business or property as a result of conduct contrary to the antitrust laws can demand from the wrongdoer treble compensation for the losses suffered. The trebling of damages does not depend upon the discretion of the court nor upon whether the defendant's conduct was intentional, reckless, or malicious. Certainly, the multiplication of damages is also designed to take into account the difficulties which plaintiffs often

415 U. S. C. $\S 15$ (1964). 
encounter in proving the full extent of their loss in these cases. What is probably more important is the conviction that private litigation in this field is, in the words of the U. S. Supreme Court, "a vital means of enforcing the antitrust policy of the United States." 5 Accordingly, the main purpose of the treble-damage action is to encourage parties affected by a violation of the antitrust law to prosecute the breach. "The portion of damages in excess of the loss is, so to speak, a reward for conduct viewed as socially useful and considered desirable as a matter of legal policy." 6

\section{B. Relief from Attorneys' Fees and Court Costs}

A plaintiff's decision whether to initiate litigation depends in many cases upon the expenses to be expected in connection with a lawsuit. We should therefore consider whether, in cases where conducting litigation is in the public interest, there are special rules to increase the plaintiff's incentive to litigate by relieving him from all or part of his expenses.

\section{The United States}

In the United States, under the so-called "American Rule" on attorneys' fees, each party must bear the cost of his legal representation in civil suits regardless of outcome. I do not purport here to assess the merits or demerits of the "American Rule," which has been severely criticized in recent years. ${ }^{7}$ Inevitably, the Rule operates to deter some individuals from instituting meritorious claims in the courts because even successful claimants remain saddled with the fees of their own attorneys. In order to counteract these conse-

5 Perma Life Mufflers v. International Parts Corp., 392 U. S. 134, 139 (1968).

6 Stoll, Consequences of Liability: Remedies (Chapter 8) in Vol. XI (Torts) of the INTERNAtional Encyclopedia of Comparative Law, at 115 (Tübingen/Paris/New York, Mohr/Mouton/Oceana), with further references.

7 See, e.g., Mc Laughlin, The Recovery of Attorney's Fees: A New Metbod of Financing Legal Services, 40 Fordham LAw Review 761 (1972); Ehrenzweig, Reimbursement of Counsel Fees and the Great Society, 54 California Law Review 792 (1966); Stoebuck, Counsel Fees Included in Costs: A Logical Development, 38 University of Colorado Law Review 202 (1966); Kuenzel, The Attorney's Fee: Why Not a Cost of Litigation?, 49 Iowa Law Review 75 (1963); McCormick, Counsel Fees and Other Expenses of Litigation as an Element of Damages, 15 MinNeSOTA Law Review 619 (1931); Comment, Court Awarded Attorney's Fees and Equal Access to the Court, 122 University of Pennsylvania Law Review 636, 648-55 (1974); Note, Attorney's Fees: Where Shall the Ultimate Burden Lie?, 20 Vanderbilt Law Review 1216 (1967). 
quences, Congress has conferred upon the courts in some 70 federal statutes the power to award the prevailing plaintiff his attorneys' fees. ${ }^{8}$ The legislative history of these statutory attorneys' fees provisions clearly shows that their fundamental purpose is to encourage full enforcement of the substantive law. The statutes are premised upon the proposition that enforcement by private litigation is essential to effectuate the substantive statutory scheme and that the award of attorneys' fees is essential to effective private enforcement. Many of the statutory schemes to which attorneys' fees provisions are attached seek to enforce civil rights. Interpreting the purpose of the attorneys' fees provision of Title II of the Civil Rights Act of 1964, which aims at the desegregation of public accommodations, the U.S. Supreme Court said:

When the Civil Rights Act of 1964 was passed, it was evident that enforcement would prove difficult and that the Nation would have to rely in part upon private litigation as a means of securing broad compliance with the law. A Title II suit is thus private in form only. When a plaintiff brings an action under that Title ... he does so not for himself alone but also as a "private attorney general," vindicating a policy that Congress considered of the highest priority. If successful plaintiffs were routinely forced to bear their own attorneys' fees, few aggrieved parties would be in a position to advance the public interest by invoking the injunctive powers of the federal courts. Congress therefore enacted the provisions for counsel fees ... to encourage individuals injured by racial discrimination to seek judicial relief under Title II. ${ }^{9}$

Other statutes to which attorneys' fees provisions are attached seek to vindicate free speech interests, to protect the environment, to provide free access to information, to enforce fair labor practices, to secure compliance with safety standards, and so on. In enacting attorneys' fees provisions Congress always had two related objectives in mind. First, it sought to achieve the fullest possible voluntary compliance with statutory duties by providing a readily available private remedy. In this sense the attorneys' fees provisions act as a de-

${ }^{8}$ A list of these federal statutes is to be found in Berger, Court Awarded Attorneys' Fees: What is Reasonable?, 126 University of Pennsylvania Law Review 281, 303-04 (1977).

${ }^{9}$ Newman v. Piggie Park Enterprises, Inc., 390 U. S. 400, 401-02 (1968). The Civil Rights Attorney's Fees Awards Act of 1976 laid down the general principle that in all civil rights cases "the court, in its discretion, may allow the prevailing party, other than the United States, a reasonable attorney's fee as part of the costs." See 42 U. S. C. A. § 1988 (1976); Note, Promoting the Vindication of Civil Rights Through the Attorney's Fees Awards Act, 80 Columbia Law REVIEW 346 (1980). 
terrent to non-compliance. Second, the availability of an award of attorneys' fees enables those who have been aggrieved by a violation of the statute to vindicate their rights, both for themselves and, acting as private attorneys general, for others similarly situated.

Some courts have gone further by holding that prevailing plaintiffs may be awarded attorneys' fees under the "private attorney general" rationale even where the power to do so has not been conferred specifically upon the court by the federal statute under which the plaintiff seeks relief. ${ }^{10} \mathrm{~A}$ famous case dealing with that problem is Alyeska Pipeline Service Co. v. Wilderness Society. ${ }^{11}$ In this case, various environmentalist groups, namely the Wilderness Society, the Environmental Defense Fund, and the Friends of the Earth brought suit against the Secretary of the Interior, the State of Alaska, and the Alyeska Pipeline Co., which was owned by a number of very large oil companies. The environmentalist groups were seeking declaratory and injunctive relief against the issuance of permits that would have allowed Alyeska to construct a trans-Alaska pipeline. After extended litigation, the environmentalist groups succeeded in obtaining a permanent injunction from the Court of Appeals for the District of Columbia Circuit whereby the issuance of the permits sought by Alyeska was disallowed as being contrary to the Mineral Leasing Act. Thereupon Congress revised the Act so as to allow the granting of the permits, but at the same time it imposed more stringent safety standards and required Alyeska to bear the costs of applying for the permits. The revision of the Mineral Leasing Act, however, effectively terminated the merits of the litigation, and the Court of Appeals was left with the plaintiffs' request for an award of attorneys' fees. These fees were enormous, since extensive factual discovery in the true American style, as well as expert scientific analysis and legal research on a broad range of environmental and technological issues, had been required. By a $4: 3$ decision, the Court of Appeals held for the plaintiffs and granted the award for attorneys' fees

10 See, e.g., Souza v. Travisono, 512 F.2d 1137 (1975); Hoitt v. Vitek, 495 F.2d 219 (1974); Knight v. Auciello, 453 F.2d 852 (1972); Cornist v. Richland Parish School Board, 495 F.2d 189 (1974); Fairly v. Patterson, 493 F.2d 598 (1974); Cooper v. Allen, 467 F.2d 836 (1972); Lee v. Southern Home Sites Corp., 444 F.2d 143 (1971); Taylor v. Perini, 503 F.2d 899 (1974); Morales v. Haines, 486 F.2d 880 (1973); Donahue v. Staunton, 471 F.2d 475 (1972); Fowler v. Schwarzwalder, 498 F.2d 143 (1974); Brandenburger v. Thompson. 494 F.2d 885 . (1974).

11 Wilderness Society v. Morton, 495 F. 2 d 1026 (1974); Alyeska Pipeline Service Co. v. Wilderness Society, 421 U. S. 240 (1975). 
although there was no express statutory authorization to do so. As Judge Skelly Wright concluded:

Acting as private attorneys general, not only have [plaintiffs] insured the proper functioning of our system of government, but they have advanced and protected in a very concrete manner substantial public interests. An award of fees would not have unjustly discouraged [defendant] Alyeska from defending its case in court. And denying fees might well have deterred [plaintiffs] from undertaking the heavy burden of this litigation. ${ }^{12}$

This decision was reversed by the U.S. Supreme Court ${ }^{13}$ because a majority believed that only Congress, not the courts, can authorize an exception to the "American Rule" based on the "private attorney general" approach. Mr. Justice Marshall filed an impressive dissenting opinion in which he argued that federal courts have the equity power to award attorneys' fees on a private-attorney-general rationale in the absence of statutory authorization and that the plaintiffs, by undertaking litigation against the Federal Government and a consortium of giant oil companies, had succeeded in ensuring a thorough analysis of the pipeline's environmental impact and therefore had acted in the interest of the general public.

\section{Germany}

In German law, the allocation of attorneys' fees (and court costs) ${ }^{14}$ is based on the principle "loser pays all." Consequently, a potential plaintiff might be deterred from bringing a lawsuit not by being saddled with his attorney's fees if he wins but by the specter of having to pay his opponent's litigation expenses if he loses. However, a number of German statutes provide the machinery by which an unsuccessful plaintiff may be relieved in part from his duty to bear his opponent's expenses. In order to understand the mechanism one must be aware that under German law the amount payable by the parties as attorneys' fees and court costs is determined not by the

12 Wilderness Society v. Morton, 495 F.2d 1036 (1974).

13 Alyeska Pipeline Service Co. v. Wilderness Society, 421 U. S. 240 (1975).

14 In contrast to most common law countries, court costs form a substantial part of the overall litigation expenses in Germany. 
time spent by the attorneys or the court on the case but solely by the amount at stake in the controversy.

Accordingly, the statutes provide that a plaintiff, upon a showing that he would be financially unable to bear his prevailing opponent's litigation expenses, may ask the court to set the value of the controversy at a level well below the real amount at stake. This is of no consequence if the plaintiff prevails: under the principle "loser pays all" he will then recover court costs and attorney's fees from the defendant computed on the basis of the real amount at stake. However, if the plaintiff loses, he will have to bear his opponent's litigation expenses only to the extent to which they are justified on the basis of the reduced amount at stake.

Most of the statutes authorizing the court to reduce the amount in controversy in this way deal with situations in which the plaintiff's pecuniary interest in the outcome of litigation, if any, would not normally justify incurring the risk of having to pay full litigation expenses to the successful opponent. On the other hand, there is in these cases a strong public interest in having the litigation initiated and judicial controls invoked. A good example is sec. 247 of the German Stock Corporation Law. ${ }^{15}$ Under this provision, the value assigned to the litigation may be reduced by the court in cases in which a shareholder seeks to contest a resolution of the shareholders' general meeting as being contrary to the law or to the articles of association. Since the value assigned to the litigation is normally determined by considering the significance of the matter for both parties, including the defendant corporation, obviously in some cases huge amounts can be determined to be at stake, resulting in very substantial court costs and attorneys' fees. On the other hand, the plaintiff might own only a few shares, and the actual damages suffered by him as a result of the illegal shareholders' resolution might be negligible. As there is a strong public interest in having someone invoke judicial control of allegedly illegal corporate action, the legislature introduced in 1965 the machinery just described and thereby provided an incentive for, or rather removed a deterrent against, litigation initiated by individual shareholders contesting the validity of resolutions of general meetings.

A similar provision in sec. -23 a of the Law Against Unfair

15 Aktiengesetz: Law of September 6, 1965, [1965] BGBl. I 1089. 
Competition ${ }^{16}$ is based on the same rationale. Under this law, actions may be brought for injunctive relief and, in some cases, for damages against defendants who have engaged in deceptive advertising or in other conduct contrary to honest business practices. Standing is granted under the Law not only to competitors and trade associations, but also to consumer associations. Again, one has no difficulty in conceiving of cases where a consumer association would be deterred from seeking injunctive relief if it had to pay the successful opponent's full attorney's fees. Accordingly, in the interest of a more effective implementation of its policy, the Law provides for a judicial reduction of the value assigned to the controversy. This reduction may take place for the benefit not only of a plaintiff, but also of a defendant. Suppose a consumer-oriented periodical publishes a critical report of the most recent VW model. If the publishers were sued by VW on the allegation that the report was biased and one-sided, they might be unable to defend the action in court, because losing the suit would mean bankruptcy if the normal method were employed of assigning a value to the controversy by taking VW's interest in the matter into consideration. In cases of this type, use of the normal procedure might in effect mean putting a muzzle on the consumer-oriented press. Therefore, in order to avert or reduce that danger, sec. 23 a of the Law was passed.

Similar dangers exist in the field of trademarks, patents, and related rights. A large company might use another party's trademark or patent with impunity if it could safely assume that the chances of being sued were remote in view of the other party's limited financial resources and its resulting inability to absorb the risk of having to pay full litigation expenses, including the defendant's attorneys' fees. Accordingly, the Patent Law (sec. 53), ${ }^{17}$ the Trademark Law (sec. 31a), ${ }^{18}$ and the Law on Utility Models (sec. 17a) ${ }^{19}$ all provide for the above-mentioned reduction machinery. In my view, the time is ripe in Germany to extract the basic principle from these isolated statutory provisions and to enact a general rule to the effect that the value assigned to any litigation may be reduced by the court for the

16 Gesetz gegen den unlauteren Wettbewerb: Law of June 7, 1909, [1909] RGBl. 499, to which sec. 23a was added by the Law of July 21, 1965, [1965] BGBl. 625.

17 Patentgesetz: Law in the version of January 2, 1968, [1968] BGBl. I 1.

18 Warenzeichengesetz: Law in the version of January 2, 1968, [1968] BGBl. I 29.

19 Gebrauchsmustergesetz: Law in the version of January 2, 1968, [1968] BGBl. I 24. 
benefit of a party whose financial resources are too limited to take the risk of bringing an action, if it appears that the party, by bringing the action, is vindicating an important public policy. ${ }^{20}$

\section{Class Actions and Shareholders' Derivative Suits}

If one is looking for legal techniques designed to encourage the use of private litigation for the vindication of substantial public interests, major attention must be directed towards two American developments which are viewed by Continental lawyers with a mixture of awe and admiration: the class action and the shareholders' derivative suit.

\section{A. Class Actions}

The plaintiff in a class action is a member of a class of persons all of whom are in a similar position: they have all been affected or are about to be affected in a similar manner by conduct of the defendant. Suit is brought by the plaintiff not only on his own behalf, but also on behalf of all other class members similarly situated. The judgment in this action, whether favorable or not, binds all members of the class if the representation by the plaintiff was fair and adequate and if notice was given. In general, class actions follow the regular course of procedure in American courts. However, under the applicable state rules of civil procedure and under Federal Rule 23, the court should pass upon the propriety of maintaining the action as a class action, define the class, direct that the best notice practicable of the commencement and progress of the action be given to the class members and make all other appropriate orders.

Historically, the class suit was understood to be mainly a tool of procedural convenience. Since class suits are maintainable only where a joinder of all class members is impracticable, arguably a class action may reduce the burdensome impact of multiple litigation brought by many or all class members individually and thus achieve economies of time, effort, and expense. However, the development in recent years has shown that now the primary purpose of the class

20 See Kötz, supra note 1 , at $75-77$. 
action is, "even at the expense of increasing litigation, to provide means of vindicating the rights of groups of people who individually would be without effective strength to bring their opponents into court at all." 21

This purpose is perhaps less apparent in class actions brought for declaratory or injunctive relief. Suppose a black parent asks the court for an order enjoining the defendant school board from operating a segregated school system. If this action were brought as a class action on behalf of all black parents living in the school district, the impact of the litigation would be demonstrated very clearly to the court, to the press and to the public in general. However, if the action were brought by one parent only, its importance would hardly be missed either. If the plaintiff prevails in the action, the school board is under a duty to desegregate the school system vis-à-vis all blacks in the district, and there is no great difference whether other black parents in the district can demand compliance from the school board on the basis of res judicata (in the case of a class action) or on the basis of stare decisis (if the action was brought by the plaintiff individually).

The real thrust of the class action is demonstrated in cases where a group injury has been committed and an individual plaintiff sues for the total damages suffered not only by him personally, but also by all members of the group. Suppose that numerous stockholders have been misled by a false statement in a prospectus, or that thousands of ratepayers have been charged excessive rates, or that many small businessmen have been the victims of a monopoly in restraint of trade, or that large numbers of consumers have been mulcted by certain illegal charges or by certain fraudulent practices: if each party were left to assert his claim for damages alone, there would be at best a random and fragmentary enforcement, if there would be any enforcement at all. This result is unfortunate not only with respect to the individual, who will often be left with only a paper remedy worthless in practice, but it also operates seriously to frustrate the deterrent policy of the law. There would indeed be a serious danger that "by the simple device of committing numerous small wrongs, law breakers might escape the arm of justice as long as they stay clear of criminal sanctions and the reach of administrative

${ }^{21}$ Kaplan, A Prefatory Note, 10 Boston College Industrial and Commercial Law REVIEW 947 (1969). 
repressive action." 22 In this situation, the class action may serve as an effective device to cope with socially destructive conduct affecting large segments of the population. By allowing the plaintiff to sue for the aggregated damages suffered by all members of the group, the class action not only, in Professor Kaplan's words, fulfills its "historic mission" of "taking care of the smaller guy." 23 Of equal importance, by providing an effective sanction against group injuries, it also constitutes a means of enforcing the policy of the law. In this sense, the plaintiff in a class action is acting as a private attorney general advancing and protecting substantial public interests.

Arguably there is little need for litigants to act as "private attorneys general" in fields where regulatory agencies have been set up to enforce the applicable law and thereby to safeguard the public interest. In the field of securities regulation, for instance, the Securities and Exchange Commission is primarily entrusted with the administration and enforcement of the federal securities laws. However, there is little doubt in the United States today that the S.E.C., because of budgetary limitations, alternative demands on available manpower, and its inability to provide compensation to injured investors, cannot do the job alone. The initiative of private litigants, acting by way of class actions, is urgently needed to effectively protect the public's interest in full enforcement of the policy underlying the federal securities laws. This view is shared by the Commission itself. 24

This is not to say, however, that the handling of class actions is free from procedural and technical complexities. On the contrary, there is no doubt that formidable problems arise as the class grows in size, making the identification of the individual members of the class more difficult. Due process requires that the members of the class be notified of the commencement of the action, be given a chance to request exclusion from the class, and, if they choose to stay in, be given the opportunity to exercise some influence on the conduct of the case. The notice requirement can be extremely difficult and expensive to comply with if the class consists of

22 Homburger, State Class Actions and the Federal Rule, 71 Columbia Law Review 609, 641 (1971).

23 See Frankel, Amended Rule 23 From a Judge's Point of View, 32 Antitrust Law JourNAL 295, 299 (1966).

${ }^{24}$ See the statement filed by the SEC as amicus curiae in Dolgow v. Anderson, 43 F. R. D. 472 (1968). 
thousands or even millions of members and if the requirement is interpreted to mean that individual notice must be given to all identifiable members of the class. Likewise, court supervision of the distribution of the money paid by the defendant will result in a substantial administrative burden if the distributees are counted in the thousands. This is why in the famous case of Eisen v. Carlisle \& Jacquelin, ${ }^{25}$ where a violation of antitrust law was alleged and damages in the amount of 65 million dollars were sought for six million class members, one of the judges implored his colleagues "to put an end to this Frankenstein monster posing as a class action." 26 While this case is certainly not a typical one, there is no doubt that because of the difficulties in handling notice problems and other administrative matters some class actions present extraordinary problems and make consuming demands on both court and counsel. Let me mention only in passing that the developing practice in this field has raised troublesome questions about the entrepreneurial role of the representative plaintiff's counsel in bringing and settling class actions. ${ }^{27}$

\section{B. Sharebolders' Derivative Suits}

Although the shareholders' derivative suit is to be distinguished from the class action, it must be mentioned here because both actions have a clearly defined public interest aspect. The derivative suit permits a shareholder to establish himself as representative of the corporation for the purpose of maintaining the action when the regular corporate functionaries do not act, either because they themselves are the wrongdoers or because the majority in control of the corporate affairs does not want them to act. The derivative action

25 This case demonstrates the complex questions that may surround a plaintiff's attempt to maintain his suit as a class action. To understand what Mr. Justice Powell has called "the labyrinthian history" of this case see bis overview in Eisen v. Carlisle \& Jacquelin, 417 U. S. 156 (1973) (1968)

26 Chief Justice Lumbard, dissenting in Eisen v. Carlisle \& Jacquelin, 391 F.2d 555, 572

27 See Homburger, Private Suits in the Public Interest in the United States of America, in Klagen Privater im ÖFfentlichen Interesse, supra note 1, at 9, 35-37. For information on recent developments in the field of class actions see Developments in the Law - Class Actions, 89 Harvard Law Review 1318 (1976); Miller, Of Frankenstein Monsters and Shining Knights: Myth, Reality and the "Class Action Problem," 92 Harvard Law Review 664 (1979). A full discussion of the pros and cons of the class action is to be found in Australian Law Reform Commission, Access to the Courts - II: Class Actions (Discussion Paper No. 11, 1979).

8. 
must therefore be seen as a device allowing a minority stockholder to sue on behalf of a large number of other minority stockholders, often small investors, and thereby to vindicate rights of the corporation against its management and others. ${ }^{28}$ The rights litigated in a derivative suit are those of the corporation, but if the action is successful and damages have accordingly been paid or assets been restored to the corporation, all stockholders will be benefitted thereby.

Derivative suits not only provide a remedy for individual stockholders who would be unable to sue on their own. By holding corporate fiduciaries accountable for their conduct, such an action is also an effective means of enforcing the public's interest in ensuring sound corporate management. Originally, the derivative action was "born of stockholder helplessness," but in the meantime it has been described by the U. S. Supreme Court as:

the chief regulator of corporate management. [It] has afforded no small incentive to avoid at least grosser forms of betrayal of stockholders' interests. It is argued, not without reason, that without it there would be little practical check on such abuses. ${ }^{29}$

\section{Public Interest Suits}

All legal systems have rules limiting access to the court to persons who have some sort of stake in the outcome of the controversy. It is said, for instance, that a plaintiff to have standing in court must show that a "right" or a "legal right" or "some special right" or a "specific legally protected interest" has been infringed or that he suffered "some particularized injury that sets him apart from the man in the street" or an "injury or threat to a particular right of his own, as distinguished from the public's interest in the administration of law." All these formulae are fairly amorphous and have little, if any, operational value. Nor is it much easier to describe the functions served by these rules. Standing requirements are said to aim at insulating the court from busybodies and at rationing scarce judicial resources. Another argument is that unless the plaintiff is a person

${ }^{28}$ See, e.g., Homburger, supra note 27, at 40-45. Cf. Stevenson, Le "procureur général privé" dans le droit des sociétés aux Etats-Unis, 1978 RevUe INTERNATIONALE DE DROIT COMPARE 779.

${ }_{29}$ Cohen v. Beneficial Industrial Loan Corp., 337 U. S. 541, 547-48 (1949). 
whose legal position would be affected by the court's judgment he cannot be relied on to present a serious, thorough and forceful argument. Some authors contend that the basic purpose of standing requirements is to protect the political branches of government against haphazard judicial interference at the behest of a private party who asserts no individual substantive right. ${ }^{30}$ Whatever the purpose of standing requirements is, the question to be discussed here is of a different nature. We are interested in to what extent and in which way traditional standing requirements have been liberalized in the past years in order to broaden the role played by private litigation as a means of vindicating the public interest. What the class action device and the expansion of standing requirements have in common is the effect of presenting to the court issues which are larger than the individual interest of the litigant who appears in court. In class actions, however, there is always a plaintiff entitled to press his individual claim, and, therefore, problems of standing do not normally arise. Here we are concerned with situations where the traditional standing rules would prevent the plaintiff from submitting an issue to the court because the basis of his argument is not that there has been an injury or a threat to a particular right of his own, but that he is seeking to guard the public or a segment if it against allegedly illegal conduct of private persons or governmental agencies.

It should be made clear at the outset that the public interest in the enforcement of legal policy may in many cases be achieved by private litigation without any need for a relaxation of standing requirements. The reason is that it is possible in many cases to find an individual with standing to sue even under the traditional rules. If this individual's suit can be expected to lead to a court decision of strategic importance, there is no problem for a group or organization of interested citizens to treat this case as a "test case," thereby providing expert counsel and controlling the conduct of the case in all material respects. The bringing of such test cases as a form of pressure group activity has not been restricted to the United States, where is has been particularly effective in the fight for civil liberties. In Germany, too, for instance, the construction of both nuclear and conventional power plants has virtually come to a standstill in recent years, not because standing requirements were broadened but because there was no dearth of personally affected individuals willing

30 See Homburger, supra note 27 , at 49. 
to lend their names to cases financed and controlled by larger groups of citizens.

In other fields, however, the problem does not lend itself to such an easy solution. In some cases an individual with standing to sue may exist but may be unwilling, for legitimate or at least plausible reasons, to consent to litigation being conducted in his name. In other cases there is simply no individual who would qualify as a plaintiff under the traditional law of standing. Suppose a governmental agency refused to grant a company permission to emit certain harmful vapors into the air or to use certain noxious substances for dyeing foodstuffs. In this case the company would obviously have standing to challenge the agency decision. If the permission had been granted, however, it might be extremely difficult to locate an individual with sufficient standing to assert in court that his legal right to clean air or to pure foodstuffs has been affected by the allegedly illegal decision of the agency. It follows that the traditional law of standing is based on a built-in bias which unduly favors economic interests held by individuals and organizations but discriminates against "fragmented and diffuse" interests held by the public or large segments of it. For instance, if the legislature, by enacting a statute for the protection of the environment, has sought to strike a fair balance between the interests of industry, on the one hand, and the public's interest in a clean environment, on the other, it would be grossly unfair if the right to invoke judicial control over governmental action were reserved solely for use by industry. This is one of the reasons why in the recent past there has been a movement in many countries towards liberalizing the law of standing by giving private individuals a right to sue for the redress of public wrongs.

\section{A. Relator Actions in England}

In England, as in most other common law jurisdictions, only the Attorney-General may bring an action on behalf of the public for the purpose of asserting a public right or preventing a public wrong. A private individual cannot do so; he will have a remedy only where, as a result of the public wrong, he has suffered or will suffer special damage peculiar to himself. What the individual may do, however, is to draw the matter to the attention of the Attorney-General and, if 
the latter refuses to act ex officio, to ask him to consent to the individual conducting the action himself. If that consent is given, the action may be brought by the individual not on behalf of himself alone but on behalf of the public at large. Then the action becomes one by the Attorney-General "on the relation" of the individual or, more understandably, on the information provided by him. Strictly speaking, the Attorney-General is the nominal plaintiff in the action and in theory retains control over the proceedings. In reality, however, the actual conduct of the proceedings is entirely in the hands of the "relator," who will also be liable to pay the costs if the "relator action" fails.

This procedure is used in England quite frequently today, ${ }^{31}$ and, as there has been a full discussion of it in recent English cases, ${ }^{32}$ it may perhaps become an important device for the prevention of public wrongs on the instigation of private plaintiffs. In the past, "relator actions" have been brought to review the legality of local authority activities, to abate a public nuisance, to obtain a declaration that a city council was acting ultra vires in granting free bus travel to old age pensioners, ${ }^{33}$ to obtain an injunction restraining a television company from broadcasting a film believed by the "relator" to be offensive to public feeling, ${ }^{34}$ and in many other cases. ${ }^{35}$ Of course, there is a risk that in exceptional cases the Attorney-General, being what is called a "political animal," may refuse leave in a proper case, or improperly or unreasonably may delay in giving leave. Lord Denning would in that case be prepared to let the individual proceed with the action without the consent of the Attorney-General because

I regard it as a matter of high constitutional principle that if there is good ground for supposing that a government department or a public authority is transgressing the law, or is about to transgress it, in a way which offends or injures thousands of Her Majesty's

31 See Cappelletti, Governmental and Private Advocates, supra note 1, at 828-31, with reference to the position in other common law countries.

32 See the cases quoted infra in notes 33-34.

33 Prescott v. Birmingham Corporation, [1955] Ch. 210.

34 Attorney General (on the relation of McWhirter) v. Independent Broadcasting Authority, [1973] 1 All E. R. 689 (C. A.).

35 See Supreme Court Practice 1979, Order 15, Rule 11, with numerous cases. See also C. Cross, Principles of Local Government Law 203 et seq. (London, Sweet \& Maxwell, 1974); D. Benjafield \& H. Whitmore, Principles of Australian Administrative Law 226 et seq. (Sydney, Law Book Co., 4th ed., 1971). 
subjects, then in the last resort any one of those offended or injured can draw it to the attention of the courts of law and seek to have the law enforced. ${ }^{36}$

In a recent interesting case, however, the House of Lords disagreed with Lord Denning's position. They believed that the courts should not substitute their own judgment as to where the balance of public interest lies for that of the Attorney-General. ${ }^{37}$

\section{B. Suits by Associations in France and Germany}

A technique frequently used in civil law countries for broadening the traditional procedural law is to confer standing - by statute or case law - on certain organizations when it appears that actions brought by individuals are not a sufficiently effective means of protecting the public against the illegal conduct of private parties or governmental agencies.

\section{France}

Under French law, persons injured as the result of a penal law violation have always been granted the option of pursuing their claims for damages in conjunction with the criminal prosecution. According to art. 2(1) of the French Code of Criminal Procedure of 1957, the private action (action civile) for reparation of injury caused by a crime, délit, or contravention may be brought by anyone who personally suffered damage caused directly by the violation. The private action may be brought either in the criminal court, in conjunction with the action publique instituted by the state for the imposition of criminal sanctions, or in the civil court, if no action is pending in the criminal court. However, the gist of the action in both situations is the contention of the plaintiff that the defendant violated a provision of the criminal law.

Article 2(1) of the French Code of Criminal Procedure requires

36 Lord Denning in the McWhirter case, supra note 34, [1973] 1 All E. R. at 699.

37 See Gouriet v. Union of Post Office Workers, [1977] 3 W. L. R. 300, 315, 326 (H. L.). Cf. Australian Law Reform Commission, Access to the Courts - I: Standing: Public INTEREST SuITs (Discussion Paper No. 4, 1978), with a full discussion of the Gouriet case and with proposals to liberalize the Australian law of standing. 
the plaintiff to show that he personally suffered an injury caused directly by the defendant's breach of the criminal law. Nevertheless, the French Cour de Cassation has been fairly generous in granting standing to bring an action civile to associations, trade unions, and other groups. The case law is far from clear, however. It is recognized that the interests affected by the wrong must not be those of the public at large nor those of individual members of the association or group. Standing will be granted only where it appears that the collective interests of the trade or profession have been affected. There is considerable debate in France on how these general criteria are to be applied in concrete cases. In particular, the criminal and civil sections of the Cour de Cassation seem to have taken divergent approaches in the matter. ${ }^{38}$

While the extent of an association's right to sue as partie civile in criminal proceedings under the general rules of the Code of Criminal Procedure is unclear, the legislature has included in many regulatory laws specific authorization granting private organizations standing to sue as parties civiles. Thus, trade unions, temperance leagues, the national and departmental unions of family associations, and associations formed to combat racism, white slavery and prostitution are all expressly accorded standing as parties civiles. In the field of consumer protection the Loi Royer of December 27, 1973, ${ }^{39}$ provides in art. 46 that:

les associations régulièrement déclarées ayant pour object statutaire explicite la défense des intérêts des consommateurs peuvent, si elles ont été agréées à cette fin, exercer devant toutes les juridictions l'action civile relativement aux faits portant un préjudice direct ou indirect à l'intérêt collectif des consommateurs.

Most statutes provide some mechanism for screening the groups to ensure some commitment to their stated purposes and some

38 See Fisch, supra note 1 , at 62 et seq.; $1 \mathrm{H}$. Solus \& R. Perrot, Droit Judiciaire PRIVÉ 228-29, 251 (Paris, Sirey, 1961); Larguier, L'action publique menacée, [1958] RecueIL Dalloz, Chronique 29; Boulan, Le double visage de l'action civile exercée devant les juridictions répressives, [1973] JuRIS-Classeur PÉRIOdiQue I. 2563; Larguier, The Civil Action for Damages in French Criminal Procedure, 39 Tulane Law Review 687 (1965); Audinet, La Protection judiciaire des fins poursuivies par les associations, 1955 REVUE TRIMESTRIELLE DE DROIT CIVIL 213; Vouin, L'unique action civile, [1973] Recueil Dalloz Sirey, Chronique 265; Campredon, L'action collective ordinale, [1979] JURIS-ClAssEUR PÉRIODIQUE I. 2943.

39 Statute No. 73-1193, [1973] J. O. 14139. Similarly, according to art. 57 of the Belgian Loi sur les pratiques du commerce of July 14, 1971 [1971] BULLETIN LEGISLATIF BELGE 658, standing to sue is granted to all consumers' associations which, as members of the statutory Consumer Council, have been accorded official status. 
capacity to fulfill that commitment. In some cases, standing is granted only to associations which have been in existence for a certain period of time, in other cases the association or group must have been recognized by a governmental agency as serving the public interest, the recognition depending upon a showing of longevity, activity, and representativeness. ${ }^{40}$

\section{Germany}

In Germany, the Code of Criminal Procedure also provides for actions civiles whereby the victim of a criminal offense is entitled to assert his claim for compensation or other relief in conjunction with a criminal prosecution ("Adbäsionsverfabren," secs. 403 et seq. of the Code of Criminal Procedure). In contrast to France, however, this type of action is hardly ever used. ${ }^{41}$ Consequently, the problem of whether groups or associations are entitled to avail themselves of this procedure has not been discussed in Germany.

On the other hand, German law has granted associations the right to sue in their own names. But these grants are limited to certain fields of law and are always based on specific statutory provisions. The actions brought under these provisions are always ordinary civil actions tried by civil courts. In contrast to French law, such actions may only be brought for injunctive relief.

The most prominent statutory authorization for such group actions (Verbandsklagen) is found in the Law Against Unfair Competition. ${ }^{42}$ Before 1965 , the Law conferred standing to sue only on the defendant's competitors and on trade associations. Nevertheless, the courts recognized that the policy of the Law was not only to keep the competitive process free from unfair business practices, but also to secure protection for consumers at large. Because competitors and trade associations sometimes appeared to be rather slow in initiating litigation, an extension of standing to consumers' associations was made in 1965, allowing them also to seek injunctions restraining unfair business practices. This experiment has been fairly successful, perhaps not so much because of a very large number of actions

40 For details, see the article by Fisch, supra note 1 , at 65-68, with further references. $72-74$.

41 An exception is the famous Thalidomide case. $C f$. the account by Fisch, supra note 1 , at

42 Section 13(1a), introduced by the Law of July 2, 1965, [1965] BGBl. I 625. 
brought, but principally because consumers' associations, now being able to wield the "big stick" of a possible court action, are in a much better position to obtain "voluntary" compliance from potential defendants.

In recent years, various bold proposals have been made in Germany trying to adapt the American class action to the German environment and, in some way, to provide consumers' associations with standing to sue for aggregated damages. These proposals have met with strong resistance by industry. A bill worked out by the Federal Ministry of Justice ${ }^{43}$ now proposes, first, that individual consumers shall have a claim for damages if they bought goods or services relying on untrue statements of the seller and, second, that these claims, after having been assigned to a consumers' association, can be enforced by it against the seller. The assignor, however, is not required to be a member of the association. It remains to be seen what result will be achieved under these new rules. At least a first step has been taken in the right direction. ${ }^{44}$

\section{Suits by Associations as European Analogues of the Class Action}

If one looks at the French and German techniques of allowing group actions in the courts, it is clear that neither law recognizes class actions in the American style. The French answer to the problem is to grant standing to previously existing associations of persons of like interest to enable them, as aptly described by Professor Fisch, to "piggy-back their claims on the criminal process wherever any sort of criminal penalty is provided by law," 45 whereas the German solution is to confer standing upon associations to sue for injunctive relief in some selected areas of the law. These devices may certainly be called European analogues of the class action. But one must not forget that they have not been used to obtain awards of aggregated damages for groups of injured people. The reason is that German

43 See the draft of a Law for Amending the Law Against Unfair Competition of September 29, 1978, Bundestags-Drucksache 8/2145.

44 Standing to sue is granted to trade or consumer associations by a number of other German statutes. An interesting example is sec. 13 of the Law on Standard Contract Terms of December 9, 1976, by which standing is conferred on consumer associations to seek an injunction restraining the defendant from using or recommending standard contract terms found to be illegal under the Law. See Hondius, Unfair Contract Terms: New Control Systems, 26 American Journal of Comparative Law 525 (1978).

45 Fisch, supra note 1 , at 78. 
law does not allow associations to sue for damages, and that in France the association acting as partie civile may ask for damages but will in most cases receive only a nominal award such as a "franc symbolique." 46

\section{Standing in Administrative Proceedings}

So far, we have focused on French and German techniques of allowing groups and associations to sue for damages or injunctive relief in response to the actions of private individuals or organizations. Whenever such groups or associations seek to challenge governmental actions, the claim must be pursued in the administrative courts. The problems of standing arising in the context of administrative procedure are more or less identical to those arising under civil and criminal procedure.

A subject of heated debate is whether groups or associations have standing to challenge administrative decisions in the field of environmental protection. Statutory grants of standing to associations seem to be rare. In Switzerland, for instance, art. 12 of the Law on the Conservation of Nature and the Homeland of July 1, 1966, 47 confers standing to sue on organizations chartered for the purpose of protecting the environment. In Germany, proposals for similar statutory provisions have been opposed vehemently and successfully by what Professor Rehbinder has called "the united front of industry, trade unions, administrators, administrative judges and the bar." 48

In Germany, as in many other countries, associations and groups of interested citizens, in order to obtain standing, are confronted with the difficulty of qualifying under the applicable general rules which require the plaintiff to show that he has suffered damage to a legally protected interest. However, as these rules are inevitably couched in rather broad and sweeping terms, some courts have found ways and means to grant standing in appropriate cases. While

\footnotetext{
46 See id. at 78-79.

47 Federal Law on Nature and the Homeland of July 1, 1966, 166 SAmmLung DER EIDGENÖSSISCHEN GESETZE 1637 (1967).

48 Rehbinder, Umweltrecht, 40 Rabels ZeITSChrift 363, 407 (1976).
} 
German courts tend to be very restrictive, ${ }^{49}$ a more generous view seems to prevail in France, where administrative courts have always kept their doors open to associations de défense and similar groups to challenge the validity of governmental action by way of a recours pour excès de pouvoir. ${ }^{50}$ In Italy, a similar attitude appeared to be developing when a widely acclaimed decision by the Consiglio di Stato granted standing in 1973 to Italia Nostra, an association for the protection of Italy's natural, historical, and cultural treasures, to challenge the validity of an administrative act authorizing the construction of a road through a park, 51 but that decision has since been overruled by the Corte di Cassazione. ${ }^{\mathbf{5 2}}$

In the United States, review of administrative decisions is normally handled by the regular courts. The applicable rules on standing seem to be in a state of flux which cannot be described here in detail. Technically, the problem in most cases is whether a group of interested citizens may qualify as "a person ... adversely affected or aggrieved by agency action within the meaning of a relevant statute." 53 On the one hand, there are many cases which seem to be based on the rationale that such groups are to be granted standing if the illegal agency action affects the public at large and there are no individuals whose special stake in the controversy gives them a pre-

49 See, e.g., Judgment of October 23, 1969 (Administrative Court of Appeals Lüneburg), 1970 NeUe JURISTISCHE WochensChrift 773; but see also Judgment of July 2, 1971 (Administrative Court Gelsenkirchen), 1971 Deutsches Verwaltungsblatt 832; and E. Rehbinder, German Law on Standing To Sue (Morges, International Union for Conservation of Nature and Natural Resources, Environmental Law Paper No. 3, 1972); Rehbinder, Controlling the Environmental Deficit: West Germany, 24 American Journal of ComparaTIVE LAW 373 (1976).

50 See, e.g., M. Waline, Droit administratif, at Nos. 828 et seq. (Paris, Sirey, 9th ed., 1963); 2 J.-M. Auby \& R. Drago, Traité du contentieux administratif 450 et seq. (Paris, Librairie générale de droit et de jurisprudence, 1975); Fisch, supra note 1, at 69-10. See also J.-M. Auby \& M. Fromont, Les recours Contre les aCtes administratifs dans les pays de la Communauté Européene 228 et seq. (Paris, Dalloz, 1971). The authors point out (at 455) that the basic philosophies underlying administrative procedure in France and Germany differ. In Germany, its main purpose is seen in the protection of the citizen against illegal administrative action, while in France "l'accent est mis sur le contrôle de l'administration plus que sur la protection de l'administré." It follows that French courts, in order to ensure adequate judicial control over administrative action, are less strict with respect to the locus standi of the plaintiff.

51 Decision No. 253 of March 9, 1973, 97 Foro Italiano III 33 (1974).

52 Decision No. 2207 of May 8, 1978, 101 Foro Italiano I 1090 (1978). See also Decision No. 829 of the Consiglio di Stato of November 13, 1973, 97 Foro Italiano III 262 (1974), by which an association of Venetian gondoliers was denied standing to challenge the closure of some canals in Venice.

53 Administrative Procedure Act $\S 10,5$ U. S. C. $\S 702$ (80 Stat. 392). 
ferred claim to standing. ${ }^{54}$ But there are also recent cases taking a much more restrictive view of the matter. ${ }^{55}$

Even the Supreme Court decision in Sierra Club v. Morton 56 leaves mixed feelings. On the one hand, Mr. Justice Stewart, speaking for the Court, asserted that:

[a] esthetic and environmental well-being, like economic well-being, are important ingredients of the quality of life in our society, and the fact that particular environmental interests are shared by the many rather than the few does not make them less deserving of legal protection through the judicial process. ${ }^{57}$

On the other hand, in the final result, the Court denied the plaintiff, a non-profit club with a special interest in environmental protection, standing to challenge the conversion of a game reserve into a privately operated holiday resort because it had not alleged injury to itself or its members as users of the game reserve.

\section{Citizen Suits (Popularklagen)}

The tendency to lower standing barriers will come to its logical conclusion when the law of standing is abolished altogether and a basis is provided for what are called "citizen suits" in the United States and "Popularklagen" in Germany. There are a few isolated instances in various countries where such suits have been permitted, 58 but their practical importance seems to be slight. Only in the United States has the citizen suit been explicitly sanctioned on a broader basis by a number of both state and federal statutes. The Michigan Environmental Protection Act of 1970 permits private individuals to bring polluters to court without any showing that they personally have in any way been adversely affected by the defendant's conduct. ${ }^{59}$ Other states, including Minnesota and Florida, have fol-

54 See, e.g., Environmental Defense Fund v. Hardin, 428 F.2d 1093 (D. C. Cir. 1970); Scenic Hudson Preservation Committee v. Federal Power Commission, 354 F.2d 608 (2d Cir. 1965); United States v. Students Challenging Regulatory Agency Procedures (SCRAP), 412 U. S. 669 (1973).

55 See, e.g., Natural Resources Defense Council v. U. S. Environmental Protection Agency, 481 F.2d 116 (10th Cir. 1973); Warth v. Seldin, 422 U. S. 490 (1975).

56 Sierra Club v. Morton, 405 U. S. 727 (1971).

57 Id. at 734.

58 See Cappelletti, Governmental and Private Advocates, supra note 1, at 857 et seq.

59 Мich. Comp. Laws Ann. 691.1201-691.1207. See Sax \& Conner, Michigan's Environmental Protection Act of 1970: A Progress Report, 70 Michigan Law Review 1004 (1972); Sax 
lowed suit. ${ }^{60}$ At the federal level, the Clean Air Act, the Water Pollution Control Act, and the Noise Control Act, as amended between 1970 and 1972, authorize citizen suits against individuals and governmental agencies if such defendants are alleged to be in violation of control requirements and standards established by the respective Acts. ${ }^{61}$ No direct personal harm resulting from the alleged violation needs to be demonstrated by the plaintiff.

\section{E. Governmental Agencies}

So far, we have considered legal devices authorizing and encouraging public interest litigation of private individuals and private organizations. Another possibility is to entrust governmental agencies with the power to enforce the applicable law in the courts by seeking injunctive and declaratory relief and, in some cases, by suing for damages. The agency that comes first to mind in this connection is the institution of the Attorney General and its functional counterparts in non-common law countries, such as the Ministerre public, the Staatsanwalt, and the Prokuratura. However, as Professor Cappelletti has demonstrated, in most countries the Attorney General's activity in civil litigation is either non-existent or limited to status and family matters and to the protection of individuals unable to protect their own interests (e.g., minors without parents, incompetents, etc.). ${ }^{62}$

In the fields of consumer protection, environmental protection and the protection of other "diffuse and fragmented interests," the trend is to set up specialized governmental agencies. These may take various forms ranging from a special division of the Attorney General's office to separate and rather independent agencies such as the Director-General of Fair Trading and the Race Relations Board in England, the Federal Trade Commission and the Securities and Exchange Commission in the United States, or the Consumer Ombudsman in the Scandinavian countries, to give only a few exam-

\& Di Mento, Environmental Citizen Suits: Three Years' Experience Under the Michigan Environmental Protection Act, 4 Ecology Law Quarterly 3 (1974).

${ }^{60}$ Minnesota Environmental Rights Act, Minn. Stat., Ch. 116B (1971); Florida Environmental Protection Act, §§ 403, 412 of the Florida Public Health Law (1971). See Homburger, supra note 27 , at 54 .

${ }^{61}$ Clean Air Amendment Act, 42 U. S. C. $\S \S 1857-1858$ a; Federal Water Pollution Control Act Amendments of 1972, 33 U. S. C. $\$ 1365$ (Supp. II 1972); Noise Control Act of 1972, 42 U. S. C. § 4911 (Supp. II 1972).

62 See Cappelletti, Governmental and Private Advocates, supra note 1, at 788 et seq. 
ples. ${ }^{63}$ All these agencies have been granted standing to sue for injunctions and sometimes for damages. ${ }^{64}$ One must keep in mind, however, that their main tool of administering and enforcing the law is not litigation, but the refusal of licenses and permits required by law, the imposition of fines, the initiation of criminal proceedings and, last but not least, the subtle art of persuasion.

\section{Potential for Future Action}

Professor Cappelletti has asked the reporters to indicate in their reports "the potential for future action, above all, practical action such as legislative or judicial reforms." This is a most difficult assignment if it is understood to mean that our comparative survey of those devices which tend to promote public interest litigation ought to be used as a basis for detailed recommendations. Little is known about the extent to which the experience of one legal system is relevant for other legal systems. But one may be fairly safe in assuming that the more deeply imbedded an institution is in the specific political and legal environment of a given country, the more difficult it is to export that institution to another country. ${ }^{65}$ While there is considerable evidence for the thesis that in all countries with a democratic form of government a growing need is felt for securing a more effective protection of diffuse and fragmented interests, one must tread very cautiously whenever the specific institutions designed to satisfy this need in one country are recommended for adoption by other countries. The reason is that the devices we have discussed here, such as the class action, the Ombudsman, or the rules on the allocation of attorneys' fees, are not what Lawrence Friedman has called "a form of legal technology" as freely and easily exportable as the art of steel-making or performing an appendectomy. ${ }^{66}$ Instead, most of these institutions are intimately linked to a particular country's political structures and distributions of legislative, executive,

${ }^{63}$ See id. at 816 et seq.

${ }^{64}$ For example, the authority of the Federal Trade Commission was extended in 1974 to permit institution of civil actions for the redress of injuries to consumers caused by unfair or deceptive acts or practices, including refunds of money or payment of damages. Federal Trade Commission Act $\S 19$ (1974), 15 U. S. C. $\S 57 b$.

${ }^{65}$ See Friedman, Access to Justice: Social and Historical Context, in Access to Justice: Promising Institutions, supra note 1 , at 3, 28 et seq.

66 See id. 
and judicial power. I am not saying that we have a case here where Robert Seidman's "law of non-transferability of law" applies. ${ }^{67} \mathrm{I}$ do believe, however, that making an inventory of the devices used to facilitate public interest litigation in various countries is a long way from predicting that any such device is needed in another country, that it can be adopted there, and that, if adopted, it will take root and have the same impact as in its country of origin.

Let us take the question of need first. There are various ways in which the protection of diffuse and fragmented interests may be organized in a given legal system. Public interest litigation in the courts is only one of them. Another method is to make the violation of the law a criminal offense and to equip the Attorney General with sufficient staff to make the initiation of criminal proceedings a meaningful and credible sanction. Also, the responsibility for protecting the interests of amorphous groups of citizens may be shifted to a public body with ample funds and adequate powers of investigation whose primary method of restraining group wrongs is not litigation but issuing cease-and-desist orders, granting and revoking licenses, outlining detailed patterns for future conduct, imposing fines, and so on. Of course, there is evidence that governmental agencies tend to assume a bureaucratic outlook and to lose, over the years, the aggressiveness and flexibility necessary to cope with ingenious attempts to flout the policy of the law. ${ }^{68}$ Much has also been written in the United States about what is called the "capture" of regulatory agencies by the industries they are supposed to regulate. ${ }^{69}$ Nevertheless, there are many reasons why the performance of the regulatory agency may be better in one country than in another. Even within one country the agency working in the field of environmental protection may do a better job than the one entrusted with the en-

${ }^{67}$ Seidman, Administrative Law and Legitimacy in Anglopbonic Africa: A Problem in the Reception of Foreign Law, 5 .LAw AND SOcIETy REview 161, 200-01 (1970).

68 See Cappelletti, Governmental and Private Advocates, supra note 1, at 820.

69 See, e.g., M. Bernstein, Regulating Business by Independent Commission (Princeton, Princeton University Press, 1955); Huntington, The Marasmus of the ICC: The Commission, the Railroads and the Public Interest, 61 Yale Law Journal 467 (1952); J. GaLbraith, The Great Crash 171 (Boston, Houghton Mifflin, 1955):

Regulatory bodies, like the people who comprise them, have a marked life cycle. In youth they are vigorous, aggressive, evangelistic, and even intolerant. Later they mellow, and in old age - after a matter of ten or fifteen years - they become, with some exceptions, either an arm of the industry they are regulating or senile.

But see also Jaffe, The Effective Limits of the Administrative Process: A Reevaluation, 67 HaRVARD LAw REVIEW 1105 (1954). 
forcement of securities law, antitrust law, or the law relating to the control of unfair terms in standardized contracts. Consequently, the need for the adoption of techniques encouraging public interest litigation can be judged only on a country-by-country basis, and within each country a further distinction must be made with respect to the field of law in which enforcement is sought.

Then there is the question of transferability. Take the example of the class action. It has been hailed, and not without reason, as one of the most distinctive achievements of American legal genius in the recent past, and indeed it helps to explain why so many European lawyers when exposed to contemporary American law have the feeling of being submerged in a kind of oxygen bath. But I do not think that the class action can be plucked out of its American environment and transplanted to European soil without considerable modification. The reason is that it can have a similar impact in another country only if, as the United States, that country: a) raises no serious objection to an attorney acquiring a proprietary interest in the subject matter of the litigation, $b$ ) provides substantial incentives for the attorney should the class action prove successful, and $c$ ) insulates the attorney and the represented class from liability to pay the opponent's fees and expenses should the class action fail. I am not saying that it would be impossible to adapt the class action to a legal system such as the one in Germany, in which different rules exist on professional conduct, statutes fix attorneys' fees solely on the basis of the amount at stake, and the contingent fee is believed to be against public policy. ${ }^{70}$ However, my prediction is that the class action would lose a good deal of its bite in the process and that its impact would not be nearly as impressive as in its place of origin.

Finally, we must not forget that measures seeking to facilitate and encourage public interest litigation will always tend to lower or abolish standing barriers and, thus, to result in an expansion of judicial power. Whether such an expansion of judicial power is desirable under contemporary conditions is a highly controversial question. Lawyers will find agreement as to the proper roles of the different branches of government to be more difficult the greater the diversity

70 Interesting proposals for adapting the class action to the German environment have been made by Mertens, Kollektivrechtlicher Schadenersatz als Mittel des Verbraucherschutzes, 139 ZEITSCHRIFT FÜR DAS GESAMTE HANDELSRECHT UND WIRTSCHAFTSRECHT 438 (1975); and by Koch, supra note 1, at 92 et seq. 
is in their legal cultures. On the one hand, Professor Cappelletti argues that the ever increasing powers of the legislative and executive branches of government justify and indeed necessitate a corresponding broadening of judicial power. ${ }^{71} \mathrm{On}$ the other hand, the argument can be made that serious problems might arise if a democracy were to permit full-scale control of the political branches of government by a non-representative judicial branch. In many cases, however, if public interest parties were not permitted to litigate an issue, no one would be able to do so. But a lack of standing, so the counter-argument runs, in no way impairs the citizen's right to assert his views in the political forum or at the polls. The absence of individuals with standing to sue indicates only that the subject matter is committed to the surveillance of Parliament and ultimately to the political process. ${ }^{72}$ This would be acceptable, so the other side would argue, if the traditional electoral process really worked. In practice, however, it is so slow, so cumbersome, and so unresponsive that in order to overcome the individual's feeling of helplessness and exclusion from government, procedural devices must be invented which enable citizen groups to participate in the decision-making process and to invoke judicial controls. The opponents will argue that giving easy access to suits against government by abolishing standing requirements is not costless. On the contrary, flamboyant cases brought by public interest lawyers, dramatically delaying the Alaska pipeline and cancelling plans for the construction of nuclear plants or highways, cause massive obstruction and delay. ${ }^{73}$ And so the battle of arguments goes on and on.

Clearly the outcome of this debate and the place to be accorded to public interest litigation in a given country depend to a large extent on that country's patterns of thought and attitudes about the respective roles of legislation and adjudication in the law-making process. These patterns differ. We are all familiar with de Tocqueville's famous observation, written in the 1830's, that " [s]carcely any political question arises in the United States that is not resolved, sooner of later, into a judicial question." 74 I do not know what our colleagues from the political science departments think about this

\footnotetext{
71 See Cappelletti, Vindicating the Public Interest, supra note 1, at 557, note 162.

72 See Mr. Chief Justice Burger in United States v. Richardson, 418 U. S. 166, 179 (1973).

73 See Friedman, supra note 65, at 36.

741 A. De Tocqueville, Democracy in America 280 (New York, A. A. Knopf, 1945).
} 
observation today. However, if a European lawyer looks at the contemporary legal scene in America, he is impressed by the scope of judicial activity in reforming constitutional and statutory defects in the structures and practices of important social institutions. Other countries with a different political structure, a different stage of their social and economic development, a less prestigious judiciary, a stronger confidence in the fairness of bureaucratic processes, a more homogeneous society, and a more inquisitorial type of civil procedure may be less willing to follow the American example. This is why it seems to be so difficult to make hard and fast recommendations as to whether it is desirable or feasible to adopt in one country specific devices developed in another country for the purpose of broadening public interest litigation.

\section{Conclusion}

This does not mean that comparative research in the field of public interest litigation is a futile undertaking. On the contrary, it is of fundamental importance for a number of reasons. First, comparative studies in this field furnish convincing proof that in most, if not all, developed countries of the Western Hemisphere there is a clear trend toward facilitating the vindication of the public interest by changing the rules on the allocation of litigation expenses, by lowering or abolishing standing barriers, or by other devices. What might seem an isolated phenomenon to the lawyer working within the context of one legal system is thus shown to form part of a more general worldwide development. No longer can the lawsuit be understood to be merely a vehicle for settling disputes between private parties about private rights. Instead, it is increasingly being used as a means of enforcing public regulatory policy, with important consequences for the nature and function of civil adjudication in general. ${ }^{75}$ Second, a comparative study of the devices which facilitate public interest litigation in various countries provides the law reformer with tested models and ideas that might serve as a basis for reasoned proposals for similar changes in his own system. Last,

75 See Chayes, The Role of the Judge in Public Law Litigation, 89 Harvard Law Review 1281 (1976); Smit, La procédure civile comme instrument de réforme sociale, 1976 REVUE INTERNATIONALE DE DROIT COMPARÉ 449. 
comparative research on public interest litigation lends support to the proposition that in fields like the one we have discussed here the comparativist will not get very far if he looks at rules and institutions solely from the standpoint of the lawyer in the traditional sense. What is also needed is comparative research on the thoughts and attitudes about law and legal institutions in various countries. In this sense, comparative law and comparative sociology of legal systems must be considered as twin disciplines which must cooperate if meaningful results are to be achieved. 

CIVIC JUSTICE THROUGH CIVIL JUSTICE:

\author{
A NEW APPROACH TO \\ PUBLIC INTEREST ADVOCACY \\ IN THE UNITED STATES *
}

by

\author{
LOUISE G. TRUBEK \\ Executive Director, Center for Public Representation, Inc., \\ Madison, Wisconsin \\ and \\ DAVID M. TRUBEK \\ Professor of Law, University of Wisconsin-Madison
}

Why should anyone care about "access to justice?" The term is certainly grand. But what does it mean? Beyond the level of rhetoric, the topic seems to be about such recondite matters as the law of standing, methods to pay for legal services, or the organization of the courts. Are these things that matter to anyone except lawyers? And what does access have to do with justice?

Two views on this question might be contrasted. The skeptic will argue that this is just technical stuff, tinkering with the routine machinery of social life: the title, then, is puffery. The opposite view takes the claim at face value, asserting that these technical matters affect justice in basic ways.

We believe both these views to be substantially correct. On the one hand, many of the technical developments are truly marginal: they have to do with "justice" only in the most impoverished sense of the word. On the other hand, behind the aspiration for improved access lie basic issues of power and equality in society. These issues tie "access" to the strong sense of justice.

These views may seem paradoxical, but they are not. We believe that behind all the technical details of standing, attorneys fees, legal services systems, etc. lies an aspiration for what we shall call civic

* The authors acknowledge the assistance of Paul Kent, University of Wisconsin Law School Class of 1981, in research and analysis. 
justice. Civic justice means a full opportunity for all citizens to participate in the life of the commonwealth. The simple idea that all citizens must have full and equal opportunities to participate in the public realm is the basis of democratic theory and republican practice. ${ }^{1}$ Yet we know that this ideal is hard to realize in the conditions of complex, industrial societies. The reforms in legal machinery which we are concerned with reflect efforts to realize this ideal. The key to the paradox, therefore, is to unravel the relationship between the civil justice of improved "access," and the civic justice of enhanced participation.

We shall examine some institutional innovations in the United States which fall within the area of "improved access to justice." These institutions have sought to provide more effective representation for what we call "interests without groups." In our society, as in many others, the legal and governmental system has given recognition to a series of interests, such as those in environmental protection and fair treatment in the marketplace. The recognition of environmental, consumer and similar rights seems similar to earlier movements in which the state guaranteed rights of producers, labor and other organized interests. But there is a crucial difference: in the case of the newer rights, while there are discernible interests, there is no organized interest group. ${ }^{2}$ No one represents consumers the way trade associations represent producers and unions defend the interest of labor.

When the state seeks to protect interests without groups, it confronts problems very different from those encountered when it seeks to protect the more traditional interests of organized sectors of society. ${ }^{3}$ Effective protection of any interest means much more than giving formal guarantees of rights. These rights must be translated into tangible benefits, and this can only occur in the day-to-day operation of government and private entities regulated by government.

1 Gordon, Is Democracy Too Inefficient?, 5 The Public I 3 (Center for Public Representation, Madison, Wisconsin, July 1979).

${ }^{2}$ For a discussion of the situations in which the state may seek to protect "interests without groups," see D. Trubek, L. Trubek \& J. Becker, Legal Services and the Administrative State: From Public Interest Law to Public Advocacy, in Innovations in the Legal Services (Meisenheim, Verlag Anton Hain, 1980).

${ }^{3}$ For an insightful and comprehensive analysis of the problems of protecting the rights of relatively unorganized interests, see J. Handler, Social Movements and the Legal System (New York, Academic Press Inc., 1978). See also B. Weisbrod, J. Handler \& N. Komesar, Public Interest Law: An Economic and Institutional Analysis (Berkeley, University of California Press, 1978). 
In the more traditional areas, this process of translating formal guarantees into effective protection involves a complex interaction between the state and social institutions. In such areas, organized representatives of protected interests play a crucial role in assuring that rights become realities. By constant monitoring of state decisions, advocacy for favorable outcomes, and bargaining with government and other affected private groups, the interest group fosters the transformation of rights into realities. If, however, such groups do not exist, government may be hampered in its efforts to protect the interest: where social organization is weak, government alone may be incapable of effective action. From this situation comes the demand for new institutions to remedy the imbalance. Public interest law firms and similar advocacy organizations have tried to represent such "interests without groups," as substitutes for the private organizations that represent more easily organizable interests.

Our purpose is to examine public interest law and similar movements from this point of view. Our thesis is simple. In complex societies, interests can only be protected by continued and effective participation in the ongoing stream of governmental decisions. ${ }^{4}$ Public interest law and its analogues are reforms in civil justice that seek to ensure such participation for interests that are not represented by organized private groups: public interest law, therefore, reflects an aspiration for civic justice.

It is our view that public interest law firms - or analogous institutions - are often necessary if the goal of effective participation is to be realized. But we believe that such reforms are rarely, if ever, sufficient to achieve this goal. The public interest law movement helped put the issue of participation on the agenda of American politics. Public interest law firms are contributing to the defense of interests without groups. But the current efforts are insufficient to achieve effective participation. If the ideal of civic justice is to be realized, public interest law must be supplemented and reformed. The search for more complete and effective approaches to participation is the task for the 1980's.

4 D. Trubek, L. Trubek \& J. Becker, supra note 2. See also H. ERLANger, A. Christenson, D. Hermanson, \& D. Trubek, Strategies for Action: Developmental Disabilities and State Government 47-65 (Madison, Wisconsin, Center for Public Representation, 1978). 


\section{The Classic Public Interest Law Approach to Represent- ING INTERESTS Without Groups}

The 1960's was a period of social ferment in the United States, in which challenges to many institutions were raised and reforms proposed and tried. Public interest law was one such reform. Numerous public interest law firms and similar advocacy institutions were established. They worked on behalf of the environment, consumers, women, minorities, juveniles, and similar interests. 5

\section{A. The Ideology of Public Interest Law}

Public interest law covers many substantive areas. The firms come in many shapes and sizes, and the lawyers pursue diverse strategies. Yet common to most public interest law efforts was a set of ideas and assumptions that we shall call the "classic" public interest law approach to the participation of unorganized interests.

This approach was based on a critique of the American political system. The critique took as a given that it was essential to provide greater protection to the rights of citizens in their roles as consumers, and users of the environment, and to categories like children, women, etc. It concluded that the operation of the American system of "pluralist" bargaining hampered, rather than helped, the effort to protect these interests. Pluralism was supposed to ensure democracy, but it did not. While pluralist politics worked well for organized groups, who could bargain with each other and with government for rights and privileges, it worked against such unorganized interests, which were excluded from a decision-making process open only to people who could speak for organized constituencies.

The solution to the problem of diminished pluralism was to reform the system. Since the unorganized were excluded, they had to be given equal access. ${ }^{6}$ Access, in turn, was defined as legal rep-

5 For an overview of this development see Rabin, Lawyers for Social Change: Perspective on Public Interest Law, 28 Stanford Law Review 207 (1976); Council for Public Interest Law, Balancing the Scales of Justice: Financing Public Interest Law in America (Washington, D. C., 1976); J. Handler, supra note 3; B. Weisbrod, J. Handler \& N. KOMESAR, supra note 3.

6 Cappelletti \& Garth, Access to Justice: The Worldwide Movement to Make Rights Effective: A General Report, in Access to Justice: A World Survey 10-48 (Alphen aan den 
resentation: access meant having the kind of lawyers that the organized interests used, and the kind of legal advocacy they provided. ${ }^{7}$ Public interest law was a device to ensure access by providing such representation: proponents spoke of "balancing the scales of justice" by equalizing the resources available to organized and unorganized groups. ${ }^{8}$

This approach rested on several subsidiary ideas. The first was the lawyers' belief that they could produce results for unorganized client groups by legal advocacy. This faith was nurtured by the progressive jurisprudence of the Warren Court, and numerous innovations in legal doctrine. It was amplified by the belief that legal advocacy was one of the few routes open to those who sought to defend these new rights, since more direct political actions were precluded by the "unorganizability" of the interests. And it was fueled by the growing resources available for this type of activity. Not only were foundations and individuals prepared to contribute to public interest law; young lawyers were also eager to work at lower salaries for this type of firm. ${ }^{9}$

\section{B. Institutionalizing the Classic Approach}

This effort manifested itself in three institutional forms: the public interest law firm, the private law firm doing public interest work, and governmental "surrogate" advocacy offices. These depended on different sources of funding and support, but all followed the classic approach of enhancing participation by improving legal representation.

Rijn/Milan, Sijthoff \& Noordhoff/Giuffrè, Vol. I of the Florence Access-to-Justice Project Series, M. Cappelletti \& B. Garth eds., 1978); Trubek, Public Advocacy: Administrative Government and the Representation of Diffuse Interests, in ACCESS TO JUSTICE: EMERGING IssuEs AND Perspectives 445 (Alphen aan den Rijn/Milan, Sijthoff \& Noordhoff/Giuffrè, Vol. III of the Florence Access-to-Justice Project Series, M. Cappelletti \& B. Garth eds., 1979).

7 See Council for Public Interest Law, supra note 5, at ix: "Council members share a belief that the decision-making processes of government are most effective and most legitimate when all viewpoints are permitted the opportunity for full airing and critical scrutiny. Access to the courts and administrative agencies depends on the availability of lawyers."

8 Id.

9 A major factor in the rise of public interest law was pressure from socially committed recent graduates of law schools. See Erlanger, Young Lawyers and Work in the Public Interest, 1978 American Bar Foundation Research Journal 83. 


\section{The Public Interest Law Firm}

The public interest law firm concept had existed prior to the 1960 's. But the late 1960's and early 1970's witnessed a dramatic increase in the number of firms, and the areas of public interest law activity. By 1975 there were over 90 public interest law firms collectively employing over 600 attorneys. Most of these tended to be small offices with a staff of 3-6 attorneys, but fully devoted to public interest cases. Some focused on single issues, e.g., the Sierra Club Legal Defense Fund (environment), while others chose a broader range of activities. Firms like California's Public Advocates, and the Washington, D. C. Center for Law in the Public Interest worked in such diverse fields as consumer protection, mental health, employment discrimination, etc. ${ }^{10}$

Funding for these organizations came predominately from three sources: foundations and private contributions, government grants and contracts, and attorney fee awards. However, the foundations and private contributions constituted the principal source of support for the movement. During the years 1972-1975 they provided for 74 percent of public interest law funding, while 22 percent came from government and 1 percent from fee awards. ${ }^{11}$ Large national foundations, principally the Ford Foundation, were the major source of funding.

\section{Public Interest Law Efforts by Private Law Firms}

The private law firms which do public interest work can be roughly divided into two categories: those which are primarily private firms and do public interest work on a pro bono basis, and those which are primarily interested in public interest law and do private work as is necessary to "get by."

The pro bono services of private firms range across a wide spectrum from solo practitioners to pro bono departments in large law firms. These efforts, however, are limited, and only a small portion of pro bono work can be described as sustained representation of unorganized interests. ${ }^{12}$

10 Council for Public Interest Law, supra note 5, at 100-32.

11 Id. at 226-31.

$12 \mathrm{~J}$. Handler, E. Hollingsworth \& H. ERlanger, Lawyers and the Pursuit of Legal Rights (New York, Academic Press, 1978). This study estimates that an average of 
The "private" public interest law firms are firms which concentrate on public interest law, but because they are self-supporting also do traditional private law work. These firms do a mixture of work some fully subsidized or pro bono public interest work, some partially subsidized public interest work where reduced fees are offered, and some private-income-generating work. Any funding requirements not filled by the income-generating work are filled either by personal subsidies in the form of reduced salaries, or court-awarded attorney's fees. Many firms also maintain viability by reliance on a key client such as a teachers union or the ACLU.

In 1975 there were some 44 such firms employing over 160 attorneys which spent more than half their time on public interest law issues. Nearly all of these firms were founded since 1969, and tended to be small. ${ }^{13}$

\section{Governmental Advocates}

The final major development in public interest law has been the establishment of governmental advocates. These have taken different shapes in different jurisdictions. The most comprehensive program is the New Jersey Public Advocate, which represents a variety of interests including the environment, the elderly, mental patients, and consumers of utility services. Other states have government advocates for more specific functions. Wisconsin's Office of the Public Intervenor, for example, represents only environmental interests. Similarly, on the federal level, there are some specific programs such as the Public Counsel of the Interstate Commerce Commission, who speaks for consumers of transportation services. Funding for governmental advocates comes from public revenues. ${ }^{14}$

only $6.4 \%$ of billable hours was spent by members of the American Bar on pro bono work. Moreover, only $13 \%$ or less of that time can be described as devoted to advocacy for minorities and unorganized interests. Id. at 92 et seq.

${ }_{13}$ Council fOR Public Interest Law, supra note 5, at 133-40.

14 Trubek, supra note 6; Senate CommitTeE on Governmental AfFairs, 95TH Cong., 1st Sess., Study on Federal Regulation: Public Participation in Regulatory Agency Proceedings 17-22 (Comm. Print, 1977). 


\section{The Current Status}

These three institutional forms of the classical approach had emerged and taken shape by the mid-1970's. Through numerous lawsuits and other advocacy efforts they had won significant victories for the groups or interests they sought to represent. ${ }^{15}$ But these victories did not spur further institutional growth. By 1975 it was apparent that the movement could not progress unless new sources of support for public interest law activity were developed. In that year the Council for Public Interest Law issued a report entitled Balancing the Scales of Justice: Financing Public Interest Law in America. ${ }^{16}$ The report described the history of the movement, set forth its successes, outlined the need for expanded and more permanent sources of financial support, and recommended a strategy for further growth.

This strategy reflected the Council's adherence to the classic approach. ${ }^{17}$ Public interest law was seen as legal representation. Representation was to be provided by subsidized lawyers; these lawyers would work principally in non-profit, autonomous public interest law firms, but also in government advocacy units organized along similar lines, and in mixed commercial-public interest firms. The work of these lawyers would be subsidized. It was assumed that these attorneys could not secure significant support from individuals or groups concerned with defending the interests they sought to represent, since no individual had a large enough stake in any action to justify paying for an attorney, and no group could be formed to represent the interest. As a result, subsidies were essential. ${ }^{18}$ This support would come primarily from four sources:

1) continued support by organized private foundations,

2) increased support from the Bar,

15 See B. Weisbrod, J. Handler \& N. Komesar, supra note 3; J. Handler, supra note 3.

16 See Council for Public Interest Law, supra note 5.

${ }_{17}$ For a detailed analysis of the Council's position see Trubek, Book Review, 1977 WisCONSIN LAW REVIEW 303.

18 Council for Public Interest Law, supra note 5, at 6-10, and Chapter IV especially at 306-08. This rationale can also be seen in statements by one large source of the subsidy, the Ford Foundation. They note in their 1974 Annual Report (at 10): "Public interest law firms, eleven of which have been assisted by the Foundation, represent individuals and groups who, though neither indigent or handicapped in the usual sense, have substantial collective and class interests that would otherwise go unrepresented." 
3) expanded use of attorneys' fees to compensate counsel who brought successful public interest suits, and

4) Government. ${ }^{19}$

This strategy for increasing financial support has not been fully successful. None of the four sources identified in the report have produced the amount of support that was hoped for, and only government appears to offer any hope for continued large-scale financing. The movement has not developed a solid financial base. A few firms maintain adequate levels of support. Most, however, must struggle to survive. Few new firms have been started in recent years.

The slowdown in the growth of public interest law can be attributed to several factors. Success has generated opposition from various sectors adversely affected, but principally from business. ${ }^{20}$ Young lawyers are not as willing as they once were to accept below-market remuneration. ${ }^{21}$ But the major factor has been the lack of adequate financial support. Let us look at the reactions of the several financing sources.

\section{Foundations}

Originally, the most important source of funding for the public interest law movement was the large national foundation. The Ford Foundation, especially, made a major commitment in this area. In recent years, however, these foundations have begun to cut back. Few new firms have received foundation support in the last few years. And Ford and other major foundations have announced their intention of phasing out direct support for public interest law. ${ }^{22}$

\section{Bar Support}

Support from the organized Bar has been tepid. The American Bar Association (ABA) has continued to endorse public interest law

19 Council For Public Interest Law, supra note 5, at 341-61.

20 Green, Why the Consumer Bill Went Down, 126 Nation 198 (1978).

21 Erlanger, supra note 9.

22 This observation was noted by the Council for Public Interest Law, supra note 5, at 219-21, and was confirmed in telephone interviews with the Ford, Carnegie and Rockefeller Foundations on June 20, 1979. The comment from the Spokesman at Ford is typical: "Our public interest law programs are continuing, but at reduced levels. We hope to phase many of them out as they become self-sustaining." 
verbally but has given little concrete support. Indeed, when given an opportunity directly to support the movement, the ABA refused. In 1977 the Carnegie Foundation granted $\$ 250,000$ to the Council on Public Interest Law on condition that ABA members contribute twice that amount to the same fund through a dues check-off system. The challenge was never met. The ABA failed to establish the required check-off system: as a result, the Carnegie grant was cancelled. ${ }^{23}$

A few local Bars have provided modest support to public interest law. For example, the Washington, D. C. Bar has a $\$ 10.00$ dues check-off for public interest law: this yielded $\$ 105,000$ in 1978. A similar system has been established by a few other local Bars, notably Los Angeles County which raised $\$ 60,000$ in 1978 by a $\$ 5.00$ checkoff. However, when we realize that it costs $\$ 25,000-40,000$ per year to support one public interest lawyer and related services, and that the D. C. and Los Angeles experiences are the exception, rather than the rule, we can see that the organized Bar as a whole has failed to give meaningful support to public interest law.

\section{Attorneys' Fees}

The Council believed that court-awarded attorneys' fees could become a major source of funding for public interest firms. These awards, it was reasoned, would compensate lawyers who brought successful court actions to protect the rights of unrepresented groups. ${ }^{24}$ Although attorneys' fees are available in some areas of public interest practice, they are the exception, not the rule. ${ }^{25}$ The Council's hopes to revive and expand attorneys' fees after the Alyeska Pipeline decision never materialized. In that case, the United

23 The 1978 Annual Report from Carnegie indicates that the grant was paid, but later cancelled. A telephone interview on June 26, 1979, with Raul Rodrieguez of the ABA Chicago Office confirmed the fact that the program was never approved.

24 Council for Public Interest Law, supra note 5, at 348.

25 Although there are some 90 federal statutory provisions for fee awards, they cover only isolated cases. See Subcommittee on Constitutional Rights of the Senate Committee on the Judiciary, Civil Rights Attorneys' Fees Awards Act of 1976, Source Book: Legislative History, Texts and Other Documents, at Appendix A (Washington, D. C., 1976). For example, major legislation, such as the National Environmental Policy Act is not covered at all, while other acts such as the Clean Air Act are covered only in part. See Comment, Citizens Association of Georgetown v. Washington: Awarding Attorneys' Fees in Citizen Suits to Enforce the Clean Air Act, 125 University of Pennsylyania Law Review 1402 (1977); Sands, Attorneys' Fees as Recoverable Costs, 63 American Bar Association JourNAL 510 (1977). 
States Supreme Court held that attorneys' fees would only be available if explicitly provided by statute or under very narrow traditional equity concepts. ${ }^{26}$

Although there were some minor inroads made on the severe restrictions imposed by Alyeska, the decision remains basically unshaken. While Congress passed the Civil Rights Attorneys' Fees Awards Act of 1976 to allow some relief from Alyeska for civil rights cases, the Act does not eliminate all the problems involved in using attorneys' fees to support public interest practice. ${ }^{27}$ Moreover, it does not affect at all many areas of public interest practice, such as consumer and environmental law. The boldest challenge to Alyeska has come in California. In Serrano v. Priest, 20 Cal. 3d 25 (1977), the State Supreme Court held that Alyeska was not controlling in California state courts, and that "private attorneys general" could collect fees from the state if they prevailed in important cases affecting many citizens. The legislature codified this private attorney general concept in $\S 1021.5$ of the California Code of Civil Procedure. The future of the California reforms, however, is uncertain. Despite the Serrano decision, the legislature has refused to appropriate money to pay fee awards to the public interest lawyers who won this case. ${ }^{28}$

Attorney's fees are limited to specific types of cases, and thus are unavailable in many "public interest" areas. Moreover, even when available, fee awards are rarely a satisfactory technique for financing public interest practice, since the amount of the award granted, if any, is uncertain. Courts have substantial discretion in determining

26 Alyeska Pipeline Co. v. Wilderness Society, 421 U. S. 240 (1975). For a discussion of this case, reaction and responses, see Coder, Defrosting the Alyeska Chill: The Future of Attorneys' Fees Awards in Environmental Litigation, 5 Environmental AfFairs 297 (1976); Comment, Alyeska Pipeline Turns off the Tap: Can Public Interest Law Survive?, 71 NorTHwESTERN University Law Review 239 (1976); Malson, In Response to Alyeska - The Civil Rights Attorneys' Fees Awards Acts of 1976, 21 St. Louis UnIVErsity Law Journal 430 (1977).

27 Pub. L. No. $94-559$ (1976). Beyond its inherent substantive limit to civil rights, this Act like most fee awards acts does not allow recovery of fees from the federal government. See, for example, Huffman, Circuit Rules Out Government Fee Payments Under 1976 Act, 17 LEGAL Times of Washington 3 (October 1, 1979); Lipson, Beyond Alyeska - Judicial Response to the Civil Rights Attorneys' Fees Awards Act, 22 St. Louis University Law Journal 243 (1978). General efforts to repeal the governmental exception to fee awards have not received much support. In the 95th Congress, bills H 2035, H 4903, H 10,105 never received committee attention. See CCH Congressional Index, 1977-1978 Current Status of House Bills, where none of the three bills were listed among those given attention.

28 Telephone interview with Lois Salisbury of Public Advocates, Inc., San Francisco, California, June 20,1979. Also note the restrictive decisions of the California Supreme Court in County of Ingo v. City of Los Angeles, 144 Cal. Rptr. 71 (1978). 
whether to award fees, and in setting the amount of fees awarded. ${ }^{29}$ To successful plaintiffs, fee awards may be too little or too late. To unsuccessful plaintiffs, they are rarely available at all. Firms relying on these fees must take substantial risks and wait a long time to determine if their gamble pays off. To do this, they must have other sources of funding. While a few firms in specialized areas may be able to rely principally on such fees, in most areas attorneys' fees are, at best, a useful supplement to other sources of support for public interest practice. If these are unavailable, the firms are in serious trouble.

\section{Governmental Support}

The Council for Public Interest Law also recommended various types of governmental support for public interest work. ${ }^{30}$ It urged increased funding for the Legal Services Corporation, especially its efforts at collective advocacy for the poor. It encouraged more provision of legal services in categorical programs designed to help groups such as the elderly, prisoners, juveniles, and the mentally impaired. It urged the creation of what we have called "public advocates," i.e., governmental agencies charged with representing unrepresented interests. And the Council suggested federal funding to reimburse citizen groups which participate in administrative agency proceedings.

There are some promising efforts to provide public funding. The least successful has been the effort to expand the idea of public advocacy. Two state-level experiments in this area which had emerged in the late 1960's and early 1970's were the Wisconsin Office of the Public Intervenor and the New Jersey Department of Public Advocacy. ${ }^{31}$ The Public Advocate is a cabinet officer with a large legal staff that provides both group and individual representation. This Department has brought numerous cases on behalf of many different unorganized interests. The Wisconsin Office has a narrower mandate

${ }^{29}$ Compare, for example, Scheriff v. Beck, 452 F. Supp. 1254 (D. Colo. 1978), where the award was based on $\$ 35.00 /$ hour, and Creg v. Beto, 453 F. Supp. 905 (S. D. Texas 1978), where the award was based on $\$ 90.00$ /hour. Courts have also reduced recovery to the extent the parties prevailed, e.g., Jones v. Diamond, 594 F. 2d 979 (5th Cir. 1979), and if the courts feel the time spent was excessive, e.g., Cole v. Tuttle, 462 F. Supp. 1016 (N. D. Miss. 1978), where the court awarded fees for only 116 of 228 hours.

30 COUncil For Public Interest Law, supra note 5, at 345-47. at $30-32$.

${ }^{31}$ For details see Trubek, supra note 6; D. Trubek, L. Trubek \& J. Becker, supra note 2, 
- the Public Intervenor is an Assistant Attorney General who provides comprehensive collective advocacy for environmental interests. ${ }^{32}$ While these experiments have proven quite successful, efforts to expand these offices or to introduce the concept in other states have generally failed. ${ }^{33}$ An effort to create an independent government advocate for the consumer interest at the federal level was decisively defeated in 1978, after heavy lobbying by business interests. ${ }^{34}$

In other areas, there has been increased government funding. The Legal Services Corporation budget has grown substantially. Government agencies concerned with specific groups, such as the elderly and the developmentally disabled, have recognized the need for legal services to complement other aspects of their programming. For example, under the Developmentally Disabled Assistance and Bill of Rights Act, all states administering assistance to the developmentally disabled (DD) must establish "Protection and Advocacy" $(\mathrm{P} \& \mathrm{~A})$ systems to provide legal aid to protect the rights of developmentally disabled persons. ${ }^{35}$ Further, some regulatory and other administrative agencies have provided funds to facilitate appearances by representatives of affected, but unrepresented groups in agency rule-making hearings. ${ }^{36}$ This system of citizen intervention financing

${ }^{32}$ For further study on the Public Intervenor in Wisconsin see P. Dubois \& A. Christenson, Public Advocacy and Environmental Decisionmaking: The Wisconsin PubLIC Intervenor (Madison, Wisconsin, Center for Public Representation, Inc., 1977).

33 Telephone interview with Margaret Riley of the New Jersey Office of the Public Advocate, June 20, 1979.

${ }_{34}$ D. Trubek, L. Trubek, \& J. Becker, supra note 2, at 28-29; Green, supra note 19.

35 Pub. L. No. 94-103, § 113 (2) (A) (1975). For a general description see H. ERLANGER, A. Christenson, D. Hermanson \& D. Trubek, supra note 4, at 1-28.

36 The most extensive program is that established to finance citizen participation in rule-making proceedings at the Federal Trade Commission, Pub. L. No. 93-637, § 202. This program and a similar program for the Environmental Protection Agency's enforcement of the Toxic Substances Control Act are the only two Congressionally authorized programs. However, several federal agencies have found implicit authority to compensate intervenors and have done so. These agencies include the Food and Drug Administration, the Civil Aeronautics Board, the Federal Energy Administration, the Consumer Products Safety Commission, the National Highway Traffic Safety Administration, the Federal Energy Regulatory Commission, the Nuclear Regulatory Commission, and the National Oceanic and Atmospheric Administration. The status of these programs is not clear since there is some dispute over the authority agencies have to compensate intervenors without Congressional authorization. For an explanation of this situation see Administrative Law - Fee Reimbursement for Public Interest Intervenors, 66 GEORgETOwn LAw JOURNAL 931 (1978). This potential limitation on agencies is especially serious given the lack of willingness on the part of Congress to pass general citizen intervention financing, such as S. 270 in the 95 th Congress. 
has provided support for some public interest law firms and similar groups. ${ }^{37}$

These developments suggest that the public interest law movement is now in a transitional phase. The original models of public interest representation were developed with heavy foundation support. The effort to continue this pattern, and add Bar funding and attorney's fees to the support base, have been relatively disappointing. Government, however, has been more responsive to the needs identified by the movement. In this new era, it is necessary to rethink both the institutional forms through which representation is provided for interests without groups, and the advocacy strategies employed for this purpose.

The prospects for extensive government support of public interest law are uncertain. The largest program at the federal level citizen intervention financing at the Federal Trade Commission has drawn strong criticism, and its future is unclear. Moreover, it is highly unlikely that government will support the classic public interest law firm approach. Rather, if substantial government funding is forthcoming, it is likely to be in a form that will require substantial changes in public interest law's approach to advocacy for interests without groups. These changes will affect institutional forms and advocacy strategies. In the remainder of this paper we shall address the new challenges facing the movement for citizen advocacy in general, and public interest law in particular.

\section{Limits of the Classic Approach}

The public interest law firm and its public sector analogues constitued what Cappelletti and Garth have called the "second wave" of the access to justice movement in the United States. ${ }^{38}$ If this was a

37 Senate Committee on Governmental Affairs, supra note 14 , at $98-113$. This report indicates that in the first several years many citizens and groups were benefited, including public interest law firms such as the Center for Public Representation, the Center for Auto Safety, the New York Public Interest Research Group, San Francisco Consumer Action, and many others. A recent accounting of the first four years of the FTC program shows that over $\$ 2$ million has been given over to individuals and groups. See Public Participation Under Attack, 11 National Journal Reports 1678 (October 1979). However, this article goes on to note that the system of citizen intervention financing at the FTC has come under attack from business groups. This development combined with the limits on expanding such programs elsewhere (see note 35 supra) makes the future of citizen intervention financing uncertain.

38 See generally Cappelletti \& Garth, supra note 6. 
wave, it has now partially receded. Much has been accomplished. The issue of representation for interests without groups has been put on the agenda. Some new institutions have been created, and have provided effective advocacy. Some of these institutions, both in the public and private sectors, will remain as permanent aspects of the American legal and governmental scene. But the original momentum has been lost. Some of the funding sources that contributed to the rise of public interest law have evaporated. Government has taken an interest in this type of activity, but has yet to make a firm and comprehensive commitment to supporting efforts to increase participation of the unrepresented and unorganized.

The present moment presents an opportunity for those who have championed public interest law. But it is an opportunity that demands hard thinking and careful evaluation of what has been done. It is our view that we must develop new ideas based on a more comprehensive analysis of the problem of protecting interests without groups. Such rethinking is necessary if the movement is to secure the kind of government support that is essential. Public interest law was a reform in civil justice developed by lawyers who were primarily concerned with civic justice. Unfortunately, the movement has failed to secure deep and widespread support from the organized legal profession, which might have been expected to accept the need for improved access to civil justice. Thus we must try to rethink public interest law directly as an experiment in civic justice. We must ensure that projects and programs provide the most effective possible participation of representatives of interests without groups, and that the reforms can be explained to those who do care about participation and equality, but who are not basically interested in civil justice per se.

Public interest law saw that diminished pluralism denied civic justice. To deal with this, the movement emphasized two responses. First, legalism - the effort to use the courts to create and enforce rights benefiting unrepresented groups. Since legislatures had enacted numerous statutes that provided some formal rights for consumers, environmentalists, minorities and similar groups, and courts seemed willing to develop and even add to these rights, litigation provided an opportunity to translate formal entitlements into concrete gains. ${ }^{39}$ Secondly, public interest lawyers sought direct access

39 See generally J. HANDLER, supra note 3. 
to policymaking arenas, hoping by their presence in agency rulemaking procedures and other settings to offset the effect of spokesmen for industry and other organized groups. ${ }^{40}$

These efforts yielded notable gains. Courts have issued numerous orders favoring the public interest lawyer's clients. And the presence of new voices in policy arenas has had an effect on agency decisions. But there were disappointments as well. Often court orders proved difficult to enforce, as they required continuing monitoring of numerous field-level decisions. ${ }^{41}$ And often the courts, in the end, shied away from direct confrontation with agency decisions. Moreover, public interest lawyers found themselves at a distinct disadvantage in discretionary decision-making processes. ${ }^{42}$ While they were often able to make persuasive arguments for their clients, they lacked the ability to stay with issues which require years to resolve, and which ultimately involve action in a series of arenas, ranging from the courts to the legislatures. However valid the idea of advocacy equalization may be, the scope of activities it entails proved to be far beyond the capabilities of most public interest firms. ${ }^{43}$

The recognition that legalism will yield limited gains, and that advocacy equalization requires resources far beyond those currently available to the public interest law movement, brings into focus the inherent limitations of the classic public interest law firm. As an institutional response to the problem of representing interests

40 Trubek, Environmental Defense I: Introduction to Interest Group Advocacy in Complex Disputes, in B. Weisbrod, J. Handler \& N. Komesar, supra note 3, at 151-94.

41 J. HANDLER, supra note 3 , at 22-25.

42 This problem manifested itself in several ways. Sometimes courts would force agencies to follow procedural requirements, but would shy away from tampering with the discretionary substantive agency decisions. This was often the experience of public interest lawyers who tried to use the National Environmental Policy Acts to curb agency actions harmful to the environment. See Trubek \& Gillen, Environmental Defense II: Examining the Limits of Interest Group Advocacy, in B. Weisbrod, J. Handler \& N. Komesar, supra note 3, at 195. In other cases where the court would try to alter agency actions, the agencies would undermine or ignore the court decision. For example, Rabin (supra note 5) notes that the Supreme Court in U. S. v. Seeger, 380 U. S. 163 (1965), greatly expanded the conscientious objector exemption, but that the decision was widely ignored by local draft boards. Rabin goes on to note that where the court decision could not be ignored, the agency could still avoid its effects. For example, in Friends of the Earth.v. FCC, 440 F.2d 1164 (D. C. Cir. 1971), FOE won a court decision requiring that the $\mathrm{FCC}$ consider requiring TV stations to give equal time to environmental messages under the fairness doctrine if the stations aired automobile commercials, just as it previously required anti-smoking messages if cigarette commercials were aired. At first, the FCC merely tried to limit the order to the station which was the subject of the suit. Eventually, the FCC decided to restrict the fairness doctrine to exclude any non-political material.

43 Rabin (supra note 5, at 239) notes that the limited resources of the public interest firm tend to result in priorities being placed on projects where there is a high yield at low cost. 
without groups, the public interest firm depends on the viability of legalism and resource equalization. These private institutions, staffed and controlled by lawyers and working outside of government, are best at providing skilled legal argumentation at key points in the governmental process. While such argumentation may be necessary, it is rarely sufficient to secure significant, permanent gains for unorganized groups. Yet the public interest law firm structure or the analogous government public advocate does not readily lend itself to the other types of activities needed for successful advocacy.

The public interest law movement has taught us a great deal about how government works and does not work. But it has not provided a complete solution to the institutional problems of effective participation in America. That challenge remains.

\section{Toward a More Comprehensive Strategy for Participa- TION}

The challenge is immense. A full treatment would require us to deal with many aspects of social life and government, and their interactions. Our intentions here are much more modest. We describe some promising current trends in participation, related to, but going beyond the classic model of public interest law. In these trends we discern the elements of a new strategy for representation of interests without groups in American government. We seek to call attention to these possibilities.

\section{A. New Trends In Consumer Participation}

Our examples are drawn from the "consumer" area, but we use this term in a broad sense to include interest in fair treatment in the marketplace and fair treatment in the distribution of governmentfunded goods and services. The consumer area constitutes a classic example of an interest without a group. While there are consumer organizations in the United States, they are generally weak and underfunded. The degree of private organization falls far short of the importance of the interest. Consumers are not brought together by any social or occupational ties. Each has a small interest in consumer 
protection in the marketplace, but no one consumer can afford to support costly advocacy services. ${ }^{44}$ In addition, consumers of government services such as health care or other social services tend to be dependent on the bureaucracies they hope to challenge - and dependency discourages organization or confrontation. Thus, this area is a paradigm of the general problem of participation of unorganized interests in government decision-making.

There have been public interest law activities in both these "consumer" fields. Ralph Nader is the leading example of the public interest advocate for marketplace regulations. ${ }^{45}$ Specialized institutions, such as the DD Protection and Advocacy System, have been created to provide legal representation to "consumers" of social welfare programs. ${ }^{46}$ In addition to these legal services efforts, however, there are five major developments which are changing the environment in which advocacy for interests without groups occurs. In these trends, and in strategies to expand the linkages between various institutional innovations, we see the promise of greater civic justice.

The major trends we see in the "consumer" area are: increasing citizen activism, the growth of mixed citizen-government planning boards in the human services area, appointment of consumer representatives in government regulatory bodies, government concern for strengthening citizen advocacy groups, and the emerging direct relations between consumer advocates and business.

\section{Citizen Activism}

Perhaps the most dramatic example of citizen activism in the United States is the taxpayers revolt, which has used the classic progressive institutions of initiative and referendum to secure a direct voice in the expenditure of government funds. In addition to mass movements like this, we discern a growing willingness by individuals to complain to government and business when they are dissatisfied with products and policies. These efforts are evidence of

44 This is an example of the problem of collective action, about which much has been written. See M. Olsen, The Logic of Collective Action (Cambridge, Harvard University Press, 1971); Trubek, supra note 6, at 470-72.

45 Nader, of course, has been a general spokesman for participatory reform.

46 See generally H. ErLanger, A. Christenson, D. Hermanson \& D. Trubek, supra note 4 . 
popular dissatisfaction with existing structures of government, and proof of popular capacity for participation. ${ }^{47}$

The new wave of citizen activism presents a challenge to government, and the response of public officials is mixed and confused. Increased citizen militancy is a threat and an opportunity. Public officials see this new activism as a threat to their ability to plan and control public decisions, and seek to curb or deflect the militant efforts. At the same time, they recognize that the dissatisfaction which it reflects and the energy it manifests can be exploited to secure support for policies and for electoral careers. Indeed, many of the promising recent developments in civic participation stem from the confused efforts of public officials simultaneously to curb, channel, co-opt and join this wave of citizen militancy. ${ }^{48}$

\section{Citizen-Government Planning in Human Services Delivery Systems}

Another promising development is the human service council. In many areas where government is involved in providing and financing social welfare activity, planning and advocacy councils have been set up to bring affected consumers together with government and firms that provide services. These councils have responsibilities for planning and monitoring social welfare policy in a specific area. They also advocate for improved and expanded programs. By bringing consumers into the planning and monitoring process, the council improves the communication between the relatively unorganized consumer groups and government, and gives consumers a better idea of how government works. This system has been relatively effective in the operation of programs for the developmentally disabled and the handicapped. 49

\section{Interest Representation on Regulatory Boards}

In recent years, there has been increased interest in using consumer representatives on decisional boards, particularly in the occu-

47 Organized citizens action is growing in the U. S. For a basic survey see Langton, Citizen Participation in America: Current Reflections on the State of the Art, in CitIzEN PARTICIPATION IN AMERICA (Lexington, Mass., Lexington Books, S. Langton ed., 1978).

$48 \mathrm{We}$ are in need of more systematic research on the phenomena of citizen activism and reactions to it.

49 This system has been described in detail in H. Erlanger, A. Christenson, D. HerMANSON \& D. TRUBEK, supra note 4 , at Chapter 2. 
pational licensing area. California has taken the lead in mandating consumer representatives on licensing boards for doctors, nurses, optometrists, architects, and other licensed professions. Other states have followed California's example. Moreover, the concept of consumer representation has been extended to the private sector. Health insurance plans in the United States are usually run by doctors and hospitals - the providers. Recently, several states have required that a substantial number of consumer representatives be placed on the boards of these corporations. 50

\section{Government Efforts to Strengthen Private Consumer Advocacy Groups}

The current push for financing citizen intervention in all regulatory decisions is an indication that policymakers do perceive a need to institutionalize the type of advocacy public interest law has sought to provide. ${ }^{51}$ Citizen intervention financing is a technique whereby citizens who participate in administrative agency decision-making (primarily rulemaking) are compensated for the cost of preparing and presenting their testimony. The Magnussen-Moss Act, which governs the Federal Trade Commission, allows the Commission to compensate advocates for interests that, absent such support, would not be able to present their views. ${ }^{52}$ Other agencies have established similar programs. In May 1979, President Carter issued a memorandum to the Executive Department in which he indicated that he wanted them to develop a plan and to implement a procedure for citizen intervention financing. Moreover, attempts have been made to expand this technique to private regulatory agencies. Thus, the Federal Trade Commission staff has recommended that a similar program be created for private products standard-setting boards. ${ }^{53}$

Another means of strengthening private advocacy groups which is being considered is to reduce the barriers inherent in organizing groups with diffuse interests. Wisconsin just passed legislation estab-

\footnotetext{
50 See The Impact of Consumer Members on Regulatory and Licensing Boards in Wisconsin (Madison, Wisconsin, Center for Public Representation, Inc., January 1980).

51 See President's Message to Congress Recommending Measures to Increase Consumer Participation in Government, 13 WeEkLY Compilation of Presidential Documents 495 (April 6, 1977).

52 Pub. L. No. 93-637, 15 U. S. C. § 57 (a) (h).

53 See Questions and Issues for. FTC Hearings on the Proposed Standard and Certification Rule, 43 Fed. Reg. 57281, para. D, Question No. 8, December 7, 1978.
} 
lishing a Citizens Utility Board (CUB). ${ }^{54}$ This board would be a non-profit public corporation charged with representing and advocating the interests of the utility consumers of Wisconsin before any administrative or judicial proceeding, and before legislative bodies. In addition, it is charged with advising utility customers of utility costs, and energy conservation. Until the prerequisites for an elected board are met, an interim board is to be nominated by the Governor and appointed by the state senate. Once the corporation reaches 1,000 members and $\$ 10,000$, board members are to be elected on a geographic basis for staggered three-year terms by the corporation members. To become a corporation member a person must be age 18 or older and contribute between $\$ 3$ and $\$ 100$ to the corporation per year. The bill provides that all Class A investorowned utilities must allow the corporation four opportunities within two years to have information about itself and how to contribute to it made available. This will accompany the normal utility billing. Thus, the CUB statute reduces the costs of forming an organization to represent a diffuse interest by establishing an organizational framework and then informing the consumers whose interests are affected of that organization in a way which enables them to support it.

In many respects, the new CUB in Wisconsin follows the Naderproposed residential utility consumer's action group (RUCAG), especially with regard to establishing the organizational framework of the corporation. ${ }^{55}$ However, there are major differences between the

54 Wisconsin AB-2 (1979 Session), Chapter 74, Laws of 1979, signed into law November 21,1979 . The act provides for the creation of $\S 199$ of the Wisconsin Statutes, and for ongoing study of the board.

55 See Leflar \& Rogol, Consumer Participation in the Regulation of Public Utilities: A Model Act, 13 Harvard Journal on Legislation 235 (1976); D. Trubek, L. Trubek \& J. Becker, supra note 2 , at 33-35. The greatest similarities between the RUCAG proposal and the CUB bill are in the organization and purpose of the corporation. Both proposals establish nonprofit public corporations with boards of directors elected on a geographic basis with staggered three-year terms. Under both arrangements an interim board is appointed, and similar detailed election requirements are established. Both arrangements provide for staff, quarterly board meetings and an annual members meeting. The only organizational differences are that the RUCAG proposal allows 16-year-olds to become members, whereas CUB pushes the age minimum up to 18 years, and the CUB bill provides for a more explicit role for an executive director to manage the staff and business aspects of the corporation.

The scope of their duties and powers are even more similar. Both under RUCAG and CUB the corporations are charged with representing consumers at administrative, judicial, and legislative forums. In addition, under both arrangements the corporations are given information-gathering and dissemination powers. Finally, both corporations are prohibited from becoming involved in partisan politics. 
two plans with regard to informing the consumers and soliciting members. The RUCAG proposal provided for a more comprehensive, direct, and continuous method of publicizing the corporation and obtaining financing from members. Specifically, under RUCAG all public utilities were obliged to participate. In addition, the proposal called for the utilities to provide a means for utility customers to add a direct contribution to each month's utility bill which would go to the RUCAG Corporation. While lack of this key feature may hurt the Wisconsin CUB, the passage of the bill can still be viewed as a positive step taken to strengthen citizen advocacy groups.

\section{Direct Contact Between Consumer Advocates and Business}

Finally, there has been a beginning of direct consumer-business linkages without any direct government encouragement. There is an organization of consumer organizations which has been meeting regularly over a three-year period with the American Telephone and Telegraph Company to discuss mutual consumer problems at the operating company level as well as the national AT\&T level. ${ }^{56}$ Apparently, the direct interactions are an effort on the part of business to find out consumers' concerns, and to deal with consumer groups in a non-regulatory, non-confrontational posture.

\section{B. A Strategy for More Effective Representation}

The trends we have identified create the potential for more effective representation of such "interests without a group" as those of consumers of private goods and public services. The issue is what strategies should be adopted by those who wish to transform this potential into a truly effective system of interest representation. We advocate a strategy based on three key elements:

1) recognizing that there is a potential system for effective advocacy,

2) strengthening the separate elements of the system, and

3) establishing linkages between these elements.

Here we sketch briefly the elements of this strategy.

56 An example of how this can work in the area of Development Disabilities is given in H. Erlanger, A. Christenson, D. Hermanson \& D. TrubeK, supra note 4, at Chapter 3. 


\section{A Potential System}

The trends we have described are the result of a series of relatively uncoordinated efforts by citizens and government. Each of the reforms, movements, and developments can be seen as a specific response by some individuals, groups, or agencies to immediate felt needs for change. Many are ad hoc, and some may be motivated as much by a desire to forestall change as to initiate major reforms.

Citizen activism is episodic and often limited to a few highly visible issues. Government support for outside advocates is limited in scope, precarious in funding, and often administered in ways that hamper advocate independence. Representation of consumers on government boards may be accepted, but only grudgingly. Consumer representatives may be outnumbered by agency officials and spokesmen for producer interests, and hampered by lack of technical information and constituent support. Business efforts to work with consumers may be symbolic at best, and such encounters may be organized to diffuse grievances and deflect attention from basic decisions and decision-making fora.

Nevertheless, taken together, these trends could form the basis of a more effective system of consumer representation. Such a system requires the following elements:

a) conclusive evidence of "constituent" support for consumer representatives,

b) access to key decision-making points in government and business, and

c) mastery of technical issues and advocacy skills.

Organized interest groups, such as labor unions and business associations, often merge these elements. What we see in the trends described above is the possibility that these elements can be made available for the consumer interest by uniting aspects of an unorganized situation. Citizen activism, including individual complaint behavior, can generate evidence of constituent concern. The trends toward consumer representation in government and business can enhance access to key decision-making arenas and increase consumer awareness of technical issues. Finally, the growth of external advocacy groups can provide missing advocacy skills. 


\section{Strengthening the Elements}

This system derives its potential power from its several elements. It would be misleading to suggest that any of these elements is currently very strong or well-institutionalized. To ensure an effective system, each component part must be strengthened. Citizen activists must learn how to make more effective use of opportunities to object to existing policies, and to demand new ones. Opportunities for individual complaints must be enhanced, and information about who is complaining and what their grievances are must be collected more systematically, and disseminated more widely. Consumer representation on government boards must be expanded, both in the number of representatives and their technical capabilities. Consumer involvement in business must go beyond conferences and advisory groups to full participation in corporate decision-making.

\section{Establishing Linkages Between the Elements}

Finally, much more must be done to establish linkages between the elements of the system. The essence of the strategy we suggest is that what one element of the system (e.g., isolated activists) may lack, others (e.g., external advocates and governmentally appointed consumer representatives) may supply. To ensure that this occurs, the several elements must be linked together more closely. Among the most promising "linkages" are the following.

a. Linking consumer representatives on government bodies with external advocacy groups and individual advocates

Since consumers are predominantly not an organized group, consumer representatives are not necessarily drawn from some established consumer group or advocacy unit.' Linking the inside "representative" to existing external groups, therefore, will increase the clout of the internal representative by giving him or her a constituency, while giving the external group more insight into current issues. For example, if consumer representatives on DD councils are linked to outside consumer groups such as the state associations of retarded citizens, and to public interest law activities such as the P\&A System, they may be more effective within the council. 
Similarly, the outside individual consumer concerned with agency policy should be linked to the inside representative. If individual consumer complainants are channeled to the inside representative, the latter will secure additional information about the problems of the unorganized interest he "represents," and can speak with more authority within the agency.

b. Linking the individual complainant with external advocacy groups

One of the major barriers to forming groups to represent interests such as that of consumers is that everyone shares this interest to a small degree, but few feel it intensely. And it is difficult to identify and contact those who are most concerned, and thus who would be the potential militants of a private group. While those individuals who complain to government about some policy are not the only potential recruits for an external advocacy group, they are the most likely. Thus, if mechanisms could be developed to link individual complainants to existing external advocacy groups, both would be strengthened.

c. Linking consumers who deal with business with external advocacy groups and government consumer representatives

Business has recognized the need for consultation with consumers. This creates a danger and an opportunity. The opportunity is that consumers will have direct contact with business, and need not rely exclusively on contacts with government. The danger is that business will develop a set of token consumer representatives who will simply be co-opted. The maintenance of strong links between consumer spokesmen who deal with business and general consumer advocacy groups is a way to exploit this opportunity and avoid this danger.

In the same sense, it is important that consumer representatives in government maintain close contact with those who deal with business. Otherwise, the consumer voice can be divided and thus diminished. 


\section{CONCLUSION}

We have argued that public interest law was a notable reform in civil justice. Designed to offer legal services for "interests without groups," this movement quickly identified its goal as civic justice i.e., effective participation by such groups in the decision-making process. While public interest law did serve to provide "new voices for new constituencies," it did not develop an institutional structure or reform strategy adequate for effective realization of the goal of civic justice. This is not to say that public interest law is a failure, or that it is not needed. Rather, it suggests that a more comprehensive strategy is required. Such a strategy will build on the experience of public interest law, but go beyond it.

We have suggested that such a strategy must be based on several elements. It must include:

- external professional advocacy resources, of the type provided by public interest law,

— individual activists,

- internal interest representatives who participate directly in decisions of government or business,

- external constituency groups, and

- new government decisional processes that formally incorporate spokesmen for unorganized interests.

Further, these elements must be carefully linked, so that the action of each reinforces the action of the other. By developing the elements of this system, and strengthening the linkages between these elements, we may be able to effectively break the impasse of a diminished pluralism and achieve the participatory goals originally articulated by the public interest law movement. ${ }^{57}$

The time may be ripe for such efforts. The malaise of American government has brought the issue of diminished pluralism decisively to the fore. If we can develop concrete strategies, the 1980's may witness significant progress toward civic justice in the United States.

${ }^{57}$ For a detailed description of our proposed system, see L. Trubek, D. Trubek \& P. Kent, The Executive Order on Consumer Affairs Programs: New Voice for "Consumers in Federal Agencies"? (Madison, Wisconsin, Center for Public Representation, Inc., April 1980). 
PART THREE

BEYOND LEGAL REPRESENTATION:

DISPUTE PROCESSING

AND

NON-JUDICIAL ALTERNATIVES

THE THIRD WAVE

IN THE ACCESS-TO-JUSTICE MOVEMENT 



\title{
JUSTICE IN MANY ROOMS *
}

by

\author{
MARC GALANTER
}

Professor of Law, University of Wisconsin-Madison

\section{INTRODUCTION}

The "three waves" of Access to Justice ${ }^{1}$ represent more than a series of attempts at institutional reform. They also correspond to a succession of intellectual forays in which we can trace crucial developments of our understanding of law in society. As that understanding continues to grow, it may reveal to us some glimmerings of what a future fourth or fifth wave might be like.

We might begin by examining what unites the three waves - the quest for access. Access is a spatial metaphor. It is a metaphor that has proved long-lived as well as congenial to many otherwise diverse reformers. ${ }^{2}$ It may be useful to unravel some of the presuppositions that are woven into this metaphor.

* Opportunity to develop some of the ideas in this report was afforded by the support of National Institute of Law Enforcement and Criminal Justice Grant No. 78-N1-AX-0137 ("The Development of Empirical Theories of Courts"). The contents of this report are the responsibility of the author alone and do not represent the view of the Institute or of the other investigators on this grant.

I am grateful to Murray Edelman, Tom Heller, Richard Lempert, Stewart Macaulay and David Trubek for helpful responses to an earlier draft of this paper. I would also like to thank Joan E. T. Stearns and Laura Woliver for their capable assistance.

1 Professors Cappelletti and Garth have identified three successive waves of "access to justice" reform: the first is the provision of legal aid to the poor; the second is the representation of diffuse, "collective," interests (e.g., through class actions, public interest law, etc.); the third is the enlargement of concern to encompass all dispute processing institutions and procedures. See Cappelletti \& Garth, Access to Justice: The Worldwide Movement to Make Rights Effective: A General Report, in Access to Justice: A World Survey 21 et seq. (Alphen aan den Rijn/Milan, Sijthoff and Noordhoff/Giuffrè, Vol. I of the Florence Access-to-Justice Project Series, M. Cappelletti \& B. Garth eds., 1978).

2 Apart from the Florence Project, the International Legal Center adopted "access" terminology in the mid-1970's. See, e.g., J. Paul, Notes on the Study of Access as an Approach to the Comparative Study of the Development of Legal Systems (New York, International Legal Center, 1975). A Conference on "Access, Decisions to Allocate Resources, Distributive Justice 
Access to where? Where is the justice that we want to admit people to? Where does it reside? Whose is it to dispense? It would be a distortion, but perhaps a useful oversimplification, to conclude that the basic model of most inquiry into access to justice is, crudely, to get people and their grievances into court. This is too narrow: "court" has to be enlarged to include a variety of remedial agencies. And "getting in" has to be enlarged to include equipping grievants with expert help to enable effective use of the agencies. And where agencies and complaints are mismatched, it extends to changing the character of the forum, and even to changing the character of the complainant, by providing means to recognize and aggregate diffuse claims. The Florence Access-to-Justice Project is permeated by an admirable willingness to challenge assumptions about institutional design. It has welcomed proposals to make the forum more suitable to the character of the dispute and the parties, and to make the disputants capable of using the forum.

This notion of a good match between forum and dispute is set within a framework of presuppositions about disputes and forums. Typically, it is assumed that access should be to a forum external to the original social setting of the dispute, a location at which some specialized learning or expertise will be brought to bear. Remedies will be provided as prescribed in some body of authoritative learning and dispensed by experts who operate under the auspices of the state. Is the justice to which we seek access a product that is produced - or at least distributed - exclusively by the state? Such a

and the Law," jointly sponsored by the International Legal Center and the Latin American Council on Law and Development was held in Miami in April 1976. A workshop on "Access, Development and Distributive Justice" was held in Singapore later in 1976, co-sponsored by the International Legal Center and the Institute of Southeast Asian Studies. An account of these meetings is provided in J. Paul \& C. Dias, Law and Resource Distribution: A Field for Research and Policy Analysis in Law and Development (New York, International Legal Center, 1977) (report on a series of workshops co-sponsored by the International Legal Center and various regional organizations during 1976-1977). The term seems to have flourished earlier in the development administration literature. See, e.g., Schaffer \& Huang, Distribution and the Theory of Access, 6 Development and Change, No. 2 (April 1974); Schaffer \& Lamb, Exit, Voice and Access, Social Science Information (December 1974). For a critique of the "access" concept, dismissing it as lacking any empirical reference, see Griffiths, Book Review, 4 BRITISH JOURNAL OF LAW AND SOCIETY 260-86, at 280 (1977).

"Access" also found qualified welcome in more familiar quarters: in 1978, the American Bar Association chose as the theme of its twentieth Law Day celebration "The Law: Your Access to Justice." The then President of the Association cautioned that lawyers' responsibilities to provide access to legal institutions should be joined by efforts to discourage inflated notions of entitlement and unhealthy reliance on law and courts to redress grievances. Spann, Let's Make the Law an Access to Justice, 64 American Bar Association Journal 639 (1978). 
view, which I shall for convenience label "legal centralism," ${ }^{3}$ is not an uncommon one among legal professionals.

I submit that the next wave of access to justice inquiry should explore the possibility that this legal centralist model is deficient. For the moment, I want to show how several lines of social research on law lead me to question its descriptive adequacy. I will then suggest the implications for access to justice of abandoning the legal centralist paradigm.

\section{The Centrifugal Perspective: Access "in the Shadow of THE LAW"}

A convenient place to start is with a crude map of the landscape of dispute processing, a map drawn form several decades of social research on law. My recklessness in generalizing about the United States is aggravated by implying that this map might be usable in other societies as well.

Most disputes that, under current rules, could be brought to a court are in fact never placed on the agenda of any court. (For convenience, I use the term "court" to encompass all official forums, including various bodies that would not be considered courts in local terms.) This is true of criminal as well as civil matters. Many of these disputes are "resolved" by resignation, "lumping it," or "exit" by one party.

Of those disputes pursued, a large portion are resolved by negotiation between the parties, or by resort to some "forum" that is part of (and embedded within) the social setting within which the dispute arose, including the school principal, the shop steward, the administrator, etc. Negotiation ranges from adjustments which are indistinguishable from the everyday accommodations that constitute the relationship to those which are "bracketed" as disruptions or emergencies. Similarly, embedded forums range from those which are hardly distinguishable from the everyday decision-making within an institution to those which are specially constituted to handle disputes which cannot be resolved by everyday processes.

Of those disputes taken to a court (official forum), the vast majority are disposed of (by abandonment, withdrawal, or settle-

${ }^{3}$ See note 32 infra. 
ment) without full-blown adjudication, and often without any authoritative disposition by the court. Of those cases that do reach full authoritative adjudication by a court, a large portion do not involve a contest. They are uncontested either because the dispute has already been resolved (as often in divorce) or because only one party appears. ${ }^{4}$

We should not assume that courts are places where cases enter and (subject to attrition) proceed normally and typically to a trial with a genuine adversary contest and a decision according to formal rules. Instead, we should see courts as arenas in which various kinds of dispute (and non-dispute) processing take place. ${ }^{5}$ Courts are the site of administrative processing, record-keeping, ceremonial changes of status, settlement negotiations, mediation, arbitration, and "warfare" (the threatening, overpowering and disabling of opponents), as well as adjudication. Indeed, in most courts most moves into the formal adjudicatory mode are for purposes other than securing an adjudicated outcome. The principal determinants of these processes must be sought in the goals, resources and strategies of the parties (including, for this purpose, the court personnel). The "law" and the courts as institutions are not therefore unimportant - for the parties' strategic options and resources (and even goals) are to some extent supplied by the law and the institutions which "apply" it.

To sum up, courts resolve only a small fraction of all disputes that are brought to their attention. These are only a small fraction of the disputes that might conceivably be brought to court and an even smaller fraction of the whole universe of disputes.

What are we to make of this profile? Should we regard it as exposure of scandalous deficiencies? Do we wish to have more disputes enter the official system and proceed further toward definitive resolution? Is the utopia of access to justice a condition in which all disputes are fully adjudicated? Surely not, for we know enough of the costs (financial, relational, psychic) of litigation to suspect that (in American society at least) such a condition

${ }^{4}$ A. Sarat \& R. Cavanagh, Thinking about Courts: Traditional Expectations and Contemporary Challenges or The Crisis of the Courts as a Social and Political Crisis (Working Paper 1979-5, Disputes Processing Research Program, University of Wisconsin Law School, Madison); Friedman \& Percival, A Tale of Two Courts: Litigation in Alameda and San Benito Counties, 10 LAw \& Society Review 267-301 (1976). 1976). 
would be monstrous. But is cost the only problem? Suppose we could eliminate most of it by a system of publicity and anticipatory compliance? Are the benefits so appealing to us? Do we want a world in which there is perfect penetration of norms downward through the pyramid so that all disputes are resolved by application of the authoritative norms propounded by the courts? We know enough about the work of American courts to suspect that such a condition would be equally monstrous in its own way. ${ }^{6}$

In many dispute situations the participants can devise more satisfactory solutions to their dispute than can professionals constrained to apply general rules on the basis of limited knowledge of the dispute. ${ }^{7}$ The variability of preferences and of situations compared to the small number of things that can be taken into account by formal rules, ${ }^{8}$ and the loss of meaning in transforming the dispute into professional categories, suggest limits on the desirability of conforming outcomes to authoritative rules.

Apart from these practical objections, the ideal of perfect penetration of official norms is subject to the even more fundamental objection that it is a mirage, a chimera - for it attributes to rules propounded in the lofty setting of the legislature or the appellate court a single determinate meaning when "applied" in a host of

6 Two recent works dramatize this point forcefully. Noonan shows how our most esteemed courts and judges failed to be responsive to personal needs or social interests when they allowed "masks" (i.e., formal classificatory concepts) to conceal the complex human and social realities in the cases before them. J. Noonan, Jr., Persons and Masks of the Law: Cardozo, Holmes, Jefferson and Wythe as Makers of the Masks (New York, Farrar, Straus and Giroux, 1976). Analyzing some well-known contracts cases, Danzig traces the implication of the inevitable shortages of resources, limitations of skill and knowledge, and infirmities in the process of capturing the facts that attend adjudication, even at its best. He depicts even craftsmanlike and thoughtful judges making decisions that fall far short of either the satisfactory resolution of the controversy at hand or the establishment of viable controls over the area of social life in which it arose. R. Danzig, The Capability Problem in Contract Law: Further Readings on Well-Known Cases (Mineola, N. Y., Foundation Press, 1978). These accounts imply that this imperfect joinder between appellate judging and social setting afflicts not only the hidebound or the unimaginative, but also the heirs (even the patron saints) of a more expansive style of judging.

7 See Eisenberg, Private Ordering Through Negotiation: Dispute-Settlement and Rulemaking, 89 Harvard Law Review 637-81, at 658 et seq. (1976); Mnookin \& Kornhauser, Bargaining in the Shadow of the Law: The Case of Divorce, 88 YALE LAw Journal 950-97, at 956 et seq. (1979); Enker, Perspectives on Plea Bargaining, in President's Commission on Law Enforcement and the Administration of Criminal Justice, Task Force Report: The Courts (Washington, D. C., U. S. Government Printing Office, 1967), Dunlop, The Limits of Legal Compulsion, 25 John Herling's Labor Letter, Nos. $48-49$ (1975).

8 See Kennedy, Legal Formality, 2 Journal of Legal Studies $351-98$ (1973). 
particular settings. ${ }^{9}$ But most authoritative norms ${ }^{10}$ are ambiguous; variant readings are possible in any complex system of general rules; uniformity of meaning across time and space is an achievement purchased at substantial cost.

A program of subordinating all variation of the law in action to the uniformity of formal law is like a program of making all spoken language an exact replica of written language. No one would deny the utility or importance of written language, but it does not necessarily offer the best guidance about how to speak. We should be cautioned by the way that our tendency to visualize the "law in action" as a deviant or debased version of the higher law, the "law on the books," parallels folk beliefs about language usage. Ferguson observes that:

[W]riting almost never reflects speech in an exact way, written language frequently develops characteristics not found in the corresponding spoken language....

$[T]$ he use of writing leads to the folk belief that the written language is the "real" language and speech a corruption of it. This attitude seems to be nearly universal in communities which have attained the regular use of writing. ${ }^{11}$

9 Feeley, The Concept of Laws in Social Science: A Critique and Notes on an Expanded View, 10 Law \& Society Review 497-523, at 500 (1976). See Damaska's observation that "there is a point beyond which increased complexity of law, especially in loosely ordered normative systems, objectively increases rather than decreases the decisionmaker's freedom. Contradictory views can plausibly be held, and support found for almost any position." Damaska, Structures of Authority and Comparative Criminal Procedure, 84 Yale Law Journal 480-544, at 528 (1975).

10 On the presence of variant local versions of a single official law, see, e.g., H. ЈАсOB, Debtors in Court: The Consumption of Government Services (Chicago, Rand McNally, 1969); Goldstein \& Ford, The Management of Air Quality: Legal Structures and Official Behavior, 21 Buffalo Law Review 1-48 (1971); J. Wilson, Varieties of Police Behavior: The Management of Law and Order in Eight Communities (Cambridge, Harvard University Press, 1968). On contrasting local legal cultures see M. Levin, Urban Politics and the Criminal Courts (Chicago, University of Chicago Press, 1977); T. Church, Jr., A. Carlson, J.-L. Lee \& T. Tan, Justice Delayed: The Pace of Litigation in UrBAN Trial CourTs (Williamsburg, Va., National Center for State Courts, 1978).

"In seeking legal services, what a person is often buying is sophisticated prediction by a professional concerning how judges in a local jurisdiction will probably apply vague standards to the circumstances of the particular case." R. Mnookin, Bargaining in the Shadow of the Law: The Case of Divorce 29-30 (Working Paper No. 3, Centre for Socio-Legal Studies, Wolfson College, Oxford, 1979).

11 C. Ferguson, Language Structure and Language Use: Essays by Charles A. FERGUSON 222-23 (Stanford, Stanford University Press, 1971). Ferguson's conclusions about the effect of this "folk belief" on language policy suggest further parallels with the concentration of law reform energies on improvement of the written law and elimination of the "gap" between the law on the books and the law in action.

The importance of this folk belief for language development lies in the way it limits the kind of conscious intervention in the form of language planning that the com- 
The incommensurability of law in action with the law on the books should not be taken as a commendation of the status quo. Nor should the observation of the limited role of courts in resolving disputes be taken as an assertion that courts are unimportant in disputing.

The contribution of courts to resolving disputes cannot be equated with their resolution of those disputes that are fully adjudicated. ${ }^{12}$ The principal contribution of courts to dispute resolution is providing a background of norms and procedures against which negotiations and regulation in both private and governmental settings take place. This contribution includes, but is not exhausted by, communication to prospective litigants of what might transpire if one of them sought a judicial resolution. Courts communicate not only the rules that would govern adjudication of the dispute, but also possible remedies as well as estimates of the difficulty, certainty, and costs of securing particular outcomes.

The courts (and the law they apply) may thus be said to confer on the parties what Robert Mnookin and Lewis Kornhauser call a "bargaining endowment," e.g., a set of "counters" to be used in

munity will conceive of or accept. Much time and effort is often spent on questions of orthography and language reform, in the tacit assumption that changes in the written language will be followed automatically by changes in speech. Some reforming zeal is also expended on bringing pronunciation in line with existing written norms. Insofar as these various efforts are part of a standardization process which responds to the communication needs of the speech community, they may result in actual change, especially if they do not conflict with the basic phonological and grammatical structure of the language, but often the efforts fail, at least in part because the beliefs do not correspond to the realities of the written-spoken relationship.

Id. at 224 .

${ }^{12}$ Lempert usefully distinguishes various ways in which courts contribute to dispute settlement:

1) courts define norms that influence or control the private settlement of disputes;

2) courts ratify private settlements, providing guarantees of compliance without which one or both parties might have been unwilling to reach a private settlement; 3) courts enable parties to legitimately escalate the costs of disputing, thereby increasing the likelihood of private dispute settlement; 4) courts provide devices that enable parties to learn about each other's cases, thus increasing the likelihood of private dispute settlement by decreasing mutual uncertainty; 5) court personnel act as mediators to encourage the consensual settlement of disputes; 6) courts resolve certain issues in the case, leading the parties to agree on the others, and 7) courts authoritatively resolve disputes where parties cannot agree on a settlement.

Lempert, More Tales of Two Courts: Exploring Changes in the "Dispute Settlement Function" of Trial Courts, 13 Law \& Society Review 91-138, at 99-100 (1978). 
bargaining between disputants. ${ }^{13}$ Bargaining may be tacit rather than explicit. ${ }^{14}$ Such an endowment includes not only the substantive entitlements conferred by legal rules, but also the rules that enable those entitlements to be vindicated - for example, a rule excluding evidence favorable to the other party or jeopardizing the claim of the other party (e.g., contributory negligence). ${ }^{15}$ But rules are only one part of the endowment conferred by the forum: the delay, cost and uncertainty of eliciting a favorable determination also confer bargaining counters on the disputants. ${ }^{16}$ The meaning of this endowment, of course, is not fixed and invariable, but depends on

13 In the case of divorce, for example,

[ $t$ ] he legal rules governing alimony, child support, marital property and custody give each parent certain claims based on what each would get if the case went to trial. In other words, the outcome that the law would impose if no agreement is reached gives each parent certain bargaining chips - an endowment of sorts.

Mnookin \& Kornhauser, supra note 7, at 968. Another example of the transformation of rules into bargaining counters is provided by $\mathrm{H}$. Ross, Settred Out of Court: The Social Process of Insurance Claims Adjustment (Chicago, Aldine, 1970). See Damaska's conclusion that "the actual significance of the sophisticated adversary process before the jury" in American criminal cases is "to set a framework for party negotiations, providing "bargaining chips.'" Damaska, A Foreign Perspective on the American Judicial System, in STATE CourTs: A BluePrint FOR THE Future 237-42, at 240 (Williamsburg, National Center for State Courts, T. Fetter ed., 1978).

This applies to the most complex as well as to the most routine cases: thus Sarat and Cavanaugh point out that in "extended impact". cases, the involvement of the courts supplies standards and the setting for negotiations among the parties. A. Sarat \& R. Cavanaugh, supra note 4 , at 69 et seq.

${ }^{14}$ Feeley observes that:

Discussions of plea bargaining often conjure up images of a Middle Eastern bazaar, in which each transaction appears as a new and distinct encounter, unencumbered by precedent or past association. Every interchange involves higgling and haggling anew, in an effort to obtain the best possible deal. The reality of American lower courts is different. They are more akin to modern supermarkets, in which prices for various commodities have been clearly established and labeled in advance.

Feeley, Pleading Guilty in Lower Courts, 13 Law \& Society Review 461-66, at 462 (1979). See Ryan and Alfini's description of a setting in which the expectations of participants are grounded in the known upper and lower limits of the judges. Ryan \& Alfini, Trial Judges' Participation in Plea Bargaining: An Empirical Perspective, 13 Law \& Society Review 479-507, at 502 (1979)

15 Of course, this is in addition to the other functions of rules - to guide courts in adjudicating cases and to guide parties in planning, in defining their expectations, etc. Qualities that commend a rule for one purpose may make it a disaster for another. Mnookin and Kornhauser give the example of joint custody as a rule that "may have good characteristics as a background rule for private ordering but may nevertheless be unacceptable as a standard for adjudicating disputed cases." Mnookin \& Kornhauser, supra note 7 , at 980.

${ }^{16}$ Delay, cost and uncertainty are partly a product of rules - e.g., a discretionary standard involving balancing of many factors requiring detailed proofs is more costly, time-consuming and uncertain in application than a mechanical rule. But cost, delay and uncertainty also result from such nonrule factors as the number of courts and lawyers, the variability of judges, etc. 
the characteristics of the disputants: their preferences, ${ }^{17}$ negotiating skill, risk averseness, -ability to bear costs and delay, etc. A different mix of disputant capabilities may make a given endowment take on a very different significance.

Mnookin and Kornhauser refer to the bargaining between the parties as occurring "in the shadow of the law." But this is not the only kind of "private ordering" that takes place in the law's capacious shadow. ${ }^{18} \mathrm{We}$ can extend the notion of the bargaining endowment to imagine the courts conferring on disputants a "regulatory endowment." 19 That is, what the courts might do (and the difficulty of getting them to do it) clothes with authorizations and immunities the regulatory activities of the school principal, the union officer, the arbitrator, the Commissioner of Baseball, and a host of others.

Such regulatory endowments consist of a number of components. First, the courts provide models (norms, procedures, structures, rationalizations) for such regulatory activity. Second, there are

17 Mnookin and Kornhauser's suggestive analysis is both illuminated and limited by the special characteristics of divorce disputes. For the most part, the disputants display a lack of interest in general effects, such as precedents, new rules, etc. So the "preferences" of the parties lack a dimension that is present in other kinds of disputing by parties who anticipate and plan for a series of comparable disputes over time. See Galanter, Why the "Haves" Come Out Abead: Speculations on the Limits of Legal Change, 9 LAw \& Societr REview 95-160 (1974).

18 An earlier use of the shadow imagery is in Shapiro, Courts, in 5 A HandBook of Political Science 321-71, at 329 (Reading, Mass., Addison-Wesley Publishing Co., F. Greenstein \& N. Polsby eds., 1975). He refers to "legalized bargaining under the shadow supervision of an available court." And a much earlier use is found in Tocqueville, who observed in 1838:

It is a strange thing, the authority that is accorded to the intervention of a court of justice by the general opinion of mankind! It clings even to the mere formalities of justice, and gives a bodily influence to the mere shadow of the law.

1 A. De Tocqueville, Democracy in America (New York, Alfred A. Knopf, the Henry Reeve text as revised by Francis Bowen, 1953, originally published 1838). The shadow metaphor is attractive because it captures other similarities. The shape of shadows bears a lawful relationship to the original, but the proportions are changed and features can be effaced or transformed. And, the object that casts the shadow is not the energizing source of the image.

19 The distinction between negotiation and regulation is shown to be a relative one in Goldberg, Regulation and Administrative Contracts, 7 The Bell Journal of Economics 426-48 (1976). The continuity between them is displayed, for example, in the continuing relations between a university and its food service contractor, where the process of monitoring performance and negotiating adjustments partakes of (or may be interpreted as) both. Plea bargaining strikes me as another example of the overlap of bargaining and regulation. And, of course, regulation may involve an important element of bargaining, as in the relations of guards to prisoners described in G. SYKes, The Society of Captives (Princetown, Princetown University Press, 1958). Perhaps we should think of bargaining and regulation as the ends of a spectrum, along whose length we can find many intermediate (and alternating) instances. 
explicit authorizations and immunities conferred by the courts (and the law) on an immense variety of regulatory settings - the school teacher and principal, the prison warden, the agricultural cooperative, the baseball league, the union leader. Such authorizations may be explicit rulings about the regulatory activity - as in judicial doctrine about the authority of arbitrators, school officials and church bodies. ${ }^{20}$ Or they may be implicit in rules of jurisdiciton, standing and other procedural doctrines that deny admittance to cases involving certain kinds of regulatory activity.

Finally, there are the implicit authorizations and immunities that flow from the general conditions of overcommitment and passivity. Courts are reactive; they do not acquire cases on their own motion, but only upon the initiative of one of the disputants. Thus, there is delegation to the disputants to invoke the intervention of a court. The expense, delay and cumbersomeness of securing such intervention insulates all regulators by raising barriers to challenging them in the courts.

Public agencies which might monitor such regulatory activity are typically overcommitted. That is, they have more enforcement responsibilities than resources with which to carry them out. So they, too, typically tend to be reactive, responding only to complaints. And in deploying their scarce resources they understandably tend to be most responsive to the more organized and attentive of their constituents. Thus, the regulation exercised by hospitals vis-à-vis patients and their families, by landlords vis-à-vis their tenants, by universities vis-à-vis their students, by unions vis-à-vis their members, by manufacturers vis-à-vis their customers, are rarely subject to challenge by

20 The most elaborate and self-conscious current discussion of deference to, and control by, private forums is in connection with labor arbitration. See Edwards, Labor Arbitration at the Crossroads: The "Common Law of the Shop" v. External Law, 32 Arbitration Journal 65-95 (1977); Getman, Labor Arbitration and Dispute Resolution, 88 Yale Law Journal 916-49 (1979). On judicial oversight of the very different institution of commercial arbitration, see G. Goldberg, A Lawyer's Guide to Commercial Arbitration 65 et seq. (Philadelphia, American Law Institute, American Bar Association Committee on Continuing Education, 1977). On judicial response to church authority, see Note, The Role of Civil Courts in Church Disputes, 1977 Wisconsin Law REview 904-27, at 904. On judicial monitoring of the exercise of disciplinary authority by school officials, see Goss v. Lopez, 419 U. S. 565, 95 S. Ct. 729 (1975); Wood v. Strickland, 420 U. S. 308, 95 S. Ct. 992 (1975); Ingraham v. Wright, 430 U. S. 651, 97 S. Ct. 1401 (1977); and the analysis in Kirp, Proceduralism and Bureaucracy: Due Process in the School Setting, 28 Stanford Law Review 841-77 (1976). It is not suggested that regulatory activity in these forums corresponds to legal doctrine. On the impact of judicial intervention on informal adjudication by agencies of the United States Government, see, e.g., Verkuil, A Study of Informal Adjudication Procedures, 43 University of CHICAgo Law RevIEW 739-98 (1976). 
public agencies or in public forums. By a kind of legal alchemy, the expense and remoteness of the courts and the overload and lethargy of other agencies are transformed into regulatory authority which can be exercised by a host of institutions.

The relation of courts (official forums) to disputes is multidimensional. Decisive resolution, while important, is not the only (nor, I submit, the principal) link between courts and disputes. Disputes may be prevented by what courts do - e.g., by enabling planning to avoid disputes or by normatively disarming a potential disputant. Also, courts may foment and mobilize disputes, as when their declaration of a right arouses and legitimates expectations about the propriety of pursuing a claim; or changes in rules of standing suggest the possibility of pursuing a claim successfully. Further, courts may displace disputes into various forums and endow these forums with regulatory power. Finally, courts may transform disputes so that the issues addressed are broader or narrower or different than those initially raised by the disputants. Thus, courts not only resolve disputes: they prevent them, mobilize them, displace them and transform them.

The effects of a forum cannot be equated with the dispositions of the cases that come before it. ${ }^{21}$ There are a host of other effects eliciting anticipatory compliance or evasive maneuvers, stigmatizing or legitimating a line of conduct, encouraging or suppressing the making of a claim, lowering or heightening an estimation of conduct or its regulators. These effects include not only "special effects" produced by the impact of the forum's decision on the parties before it, ${ }^{22}$ but also "general effects" which result from the communication of information by/about the forum and the response of others to that information. ${ }^{23}$

21 See Richard Lempert's critical reanalysis (supra note 12, at 92 et seq.) of Friedman and Percival's data (supra note 4), emphasizing the distinction between the functions of courts in the sense of what courts do and their functions in terms of their effects on the larger society.

22 Special effects include not only the sanctions imposed by the court, but ancillary impacts of court proceedings such as effects on parties' credit rating, insurability, employment, licensing, business reputation and standing in other forums. Engel \& Steele, Civil Cases and Society: Process and Order in the Civil Justice System, 1979 American Bar Foundation ReSEARCH JOURNAL 295-346, at 316 (1979). And, of course, such effects are produced not only by the decision of the forum, but also by the costs (including benefits foregone) and timing of that decision (or its absence).

23 This notion of "general effects" takes off from the very helpful discussion of general preventive effects of punishment in J. Gibbs, Crime, Punishment and Deterrence, at Chapter 3 (New York, Elsevier Scientific Publishing Co., 1975), as usefully elaborated in 
Of course, these general effects need not be intended (or perceived) by the forum (or the disputants). Modifications of behavior in response to a perceived pattern of particular instances of forum activity would qualify as a general effect even if the forum did not call attention to that pattern and even if the forum did not perceive it. The forum may attempt to enhance certain of its effects by deliberately projecting an image of its general patterns of response. Of course, no matter what it tries to project, transmission by the forum is only part of the process. Effects will also depend on the reception side: Who gets which messages? Who can evaluate and process them? Who can use the information?

Thus, the impact of courts on disputes is accomplished largely by the dissemination of information. Courts produce not only decisions, but also messages. These messages are resources which parties use in envisioning, devising, pursuing, negotiating and vindicating claims (and in avoiding, defending and defeating them). Similarly, courts distribute resources by which some parties regulate others (or resist such regulation).

Just how potential disputants and regulators will draw on these resources is powerfully affected by their culture, their capabilities and their relations with one another. For example, we would expect that the legal endowment would be used differently in bargaining among strangers with no prospect of continuing relations (e.g., the typical automobile injury claim) than by parties to a long-term relationship. We would expect it to be used differently where disputants shared a normative consensus or where some formidable sanctions were built into the relationship. ${ }^{24}$ We would expect it to be used differently where one disputant was dependent on the other. Similarly, we would expect that the regulatory endowment would be

Feeley, supra note 9, at 517 et seq. It is simply a generalization from the illuminating and now familiar (if not entirely serviceable, as Gibbs points out) distinction between special deterrence and general deterrence introduced by Andenaes. Andenaes, The General Preventative Effects of Punishment, 114 University of Pennsylvania Law Review 949-83 (1966). Theory about these general effects is still inchoate. In a review of the now sizable literature on deterrence, Gibbs observes that since deterrence research has proceeded without controls for other general effects, "all previous reported tests of the deterrence doctrine ... were really tests of an implicit theory of general preventive effects; and that will remain the case as long as nondeterrent mechanisms are left uncontrolled." J. Gibbs, Punishment, Deterrence, and Retribution (draft chapter of a "handbook of law and social science," Committee on Law and Social Science of the Social Science Research Council, to be published c.1981).

${ }^{24}$ Macaulay, Non-Contractual Relations in Business: A Preliminary Study, 28 American Sociological Review 55-67 (1963). 
used differently in a continuing relationship than in an episodic one, and so on.

Like other legal institutions, courts have far more commitments than resources to carry them out. Enforcement agencies cannot possibly enforce all the law. Nor can individuals enforce all of their rights. In form, courts are open for full adjudicatory hearing of all cases, but, in practice, their capacity to conduct full-blown adjudications is limited to a fraction of the potential cases. Law is more capacious as a system of cultural and symbolic meanings than as a set of operative controls. It affects us primarily through communication of symbols - by providing threats, promises, models, persuasion, legitimacy, stigma, etc. ${ }^{25}$

If the nature of courts is to kiss and tell, in the nature of things they can do more telling than kissing. Their product is double: what they do and what they say about what they do. Messages about both are mediated through various channels to different audiences with

25 The appreciation of courts as cultural backdrop rather than operating control is connected, I suspect, with the tendency for such institutions to look better from afar. Those who experience courts first-hand tend to be less satisfied with them. Sarat, Studying American Legal Culture: An Assessment of Survey Evidence, 11 Law \& Society Review 427-88, at 439, 441 (1977). Unfavorable evaluations of state courts have been found to increase with both knowledge and experience with them. Yankelovich, Skelly and White, Inc., The Public IMAGE OF CourTs 11, 18 (Williamsburg, Va., National Center for State Courts, 1978). On the more critical assessment by multiple users, see B. CURRAN, The Legal NeEds OF THE Public: A Final Report of a National Survey 236 (Chicago, American Bar Foundation, 1977). Comparable responses have been found in widely different settings. Kidder reports that Indian litigants were disillusioned with the courts they had encountered, but

everyone interviewed believed that the courts above those they had directly experienced would be free of the complications they had found in their own experience .... This "grass is greener" phenomenon was as true of recent winners as it was of recent losers and showed up in [experienced] "court birds" as predictably as in the newest novice.

Kidder, Courts and Conflict in an Indian City: A Study in Legal Impact, 11 Journal of ComMONWEalth Political Studies 121-39, at 134. The gap between use and estimation appears even in the community-based Social Conciliatory Commissions, where those who think best of the SCC are higher status groups with little direct experience of their operation:

The SCC's are favored to a much lesser degree, on general criteria, by those who have actually used them as disputants - even though these former SCC users are largely satisfied with, and assess positively, the performance of the SCC in their own particular cases - and these former parties tend to be persons with characteristics of lower status.

Kurczewski \& Frieske, The Social Conciliatory Commissions in Poland: A Case Study of Nonauthoritative and Conciliatory Dispute Resolution as an Approach to Access to Justice, in Access to Justice: Promising Institutions 153-427, at 328 (Alphen aan den Rijn/Milan, Sijthoff and Noordhoff/Giuffrè, Vol. II of the Florence Access-to-Justice Project Series, M. Cappelletti \& J. Weisner eds., 1978). 
different capacities to receive and evaluate these messages. ${ }^{26}$ Audiences may differ, for example, in their ability to make a sophisticated assessment of what a court really does - i.e., what their bargaining chips really are. Similarly, it has been suggested that the effectiveness of deterrence systems varies with the capabilities of the recipients. While naive amateurs may generalize the high risk of punishment from one type of crime to another, sophisticated professionals who "make relevant distinctions and ... put the message into a refined context" will be able to extract more specific and accurate information from the deterrence message. ${ }^{27}$ Where control is exerted through communication, the system will be powerfully influenced by the information-processing capacities of the recipients - and by the disparities in their capacities. ${ }^{28}$

We have shifted from seeing courts as resolvers of those disputes which come before them to seeing courts as one component of a complex system of indirect control over the whole system of disputes (and non-disputes). Correspondingly, where we began by seeing access to justice as a problem of getting disputants into court, it now appears as a problem of how to contribute to justice in the setting where the disputants find themselves - an undertaking in which the role of courts is indirect and perhaps minor.

It is conceivable that the relative importance of these radiating effects (compared to direct effects on the disputants) is greater in the United States, which maintains a relatively small judicial plant ${ }^{29}$ but

${ }^{26}$ For a description of the political system as distributing both tangible and symbolic benefits, and the tendency for diffuse remote publics to receive the latter while more attentive organized groups enjoy the former, see M. Edelman, The Symbolic Uses of Politics, at Chapter 2 (Urbana, University of Illinois Press, 1967).

27 Geerken \& Gove, Deterrence: Some Theoretical Considerations, 9 LAw \& SociETY REVIEW 497-513, at 507 (1975).

28 Without some knowledge of the (presumably differentiated) reception process, one cannot specify the policy implications of the insight that courts are important symbolic transmitters. For example, Ball calls for cultivating and cherishing the theatrical "live performance" of courts - as dramatic embodiments or presentations of a normative image of legitimate society - dramatizing the seriousness, importance, dignity, rights and duties of citizens, surrounding them with ceremonious deference. Ball, The Play's the Thing: An Unscientific Reflection on Courts under the Rubric of Theater, 28 STANFORD LAw REview 81-116 (1975). But he neglects to say who these messages are communicated to - does it really get to a wider audience? Does it matter that we have more or fewer trials? Juries? Newspaper coverage? T. V. in courtrooms? Does it differ by size of locality, etc.?

${ }^{29}$ See E. Johnson, Jr., S. Bloch, A. Drew, W. Felstiner, E. Hansen \& G. Sabagh, Comparative Analysis of the Statistical Dimensions of the Justice Systems of Seven Industrial Democracies (a report submitted to the National Institute for Law Enforcement and Criminal Justice, 1977); Johnson \& Drew, This Nation Has Money for Everything: Except Its Courts, 17 
a very large number of lawyers. In the United States, more than in many places, law is a private sector business, ${ }^{30}$ and private ordering is a prominent part of the legal universe.

\section{The Law in the Shadow of Indigenous Regulation}

I began by portraying the access to justice movement as an effort to enhance the flow of disputes into appropriate official forums where they would find justice. I suggested that this image of centripetal movement embodies a view that for convenience may be labelled "legal centralism." By this I mean a picture in which state agencies (and their learning) occupy the center of legal life and stand in a relation of "hierarchic control" 31 to other, lesser normative orderings such as the family, the corporation, the business network. ${ }^{32}$

Just as health is not found primarily in hospitals or knowledge in schools, so justice is not primarily to be found in official justice-dispensing institutions. Ultimately, access to justice is not just a matter of bringing cases to a font of official justice, but of enhancing the justice quality of the relations and transactions in which people are engaged. People experience justice (and injustice) not only (or usually) in forums sponsored by the state, but also at the primary institutional locations of their activity - home, neighborhood, work-

Judges Journal 8 (1978). Their small numbers and passive role mean that judges in the United States are management rather than production workers. On the patterns of delegation and supervision that characterize judicial processing of cases, see Engel \& Steele, supra note 22, at 311 et seq.

${ }^{30}$ See Selznick's observations on the pervasive privatization of labor and welfare regulation in the U.S. P. Selznick, with the collaboration of P. Nonet \& H. Vollmer, Law, Society ANd Industrial Justice 229 (New York, Russell Sage Foundation, 1969).

31 See Mayhew, Stability and Change in Legal Systems, in Stability and Social Change 187-210, at 208 (Boston, Little, Brown \& Co., B. Barber \& A. Inkeles eds., 1971).

32 An attempt to explicate the "paradigm" that is here labelled legal centralism is found in Galanter, The Future of Law and Social Sciences Research, 52 North Carolina Law REVIEW 1060 (1974) (presentations at a conference on Developments in Law and Social Sciences Research); Galanter, excerpts from Notes on the Future of Social Research on the Law (unpublished paper), in LAw AND the Behavioral Sciences 18-20 (Indianapolis, Bobbs-Merrill, L. Friedman \& S. Macaulay eds., 2d ed., 1976); Trubek \& Galanter, Scholars in Self-Estrangement: Some Reflections on the Crisis in Law and Development Studies in the United States, 1974 Wisconsin Law Review 1062-1102. The label of legal centralism is borrowed from John Griffiths, who suggests that the state-centered view of legal phenomena is a kind of legal Ptolemaism. J. Griffiths, The Legal Integration of Minority Groups Set in the Context of Legal Pluralism (manuscript, 1979). Our habit of describing all legal phenomena in relation to the state Griffiths finds "essentially arbitrary ... the state has no more empirical claim to being the center of the universe of legal phenomena than any other element of that whole system does. ..." Id. at 48 . 
place, business setting and so on - (including a variety of specialized remedial settings embedded in these locations). The enunciation of norms and the application of sanctions in these settings may be more or less organized, more or less self-conscious, more or less consensual and so forth. For convenience, I shall use the terms "indigenous ordering" and "indigenous law" to refer to social ordering which is indigenous, i.e., familiar to and applied by the participants in the everyday activity that is being regulated. ${ }^{33}$ By indigenous law I refer not to some diffuse folk consciousness, but to concrete patterns of social ordering to be found in a variety of institutional settings in American society - in universities, sports leagues, housing developments, hospitals, etc. ${ }^{34}$ "Legal centralism" has impaired our consciousness of "indigenous law." 35

33 The notion of "indigenous" law as regulation by the participants engaged in an activity invites comparison with a whole battery of kindred notions. Its ancestor is Ehrlich's "inner order of the associations." E. Ehrlich, Fundamental Principles of the Sociology of LAw 38 and passim (New York, Russell \& Russell, W. Moll transl., 1936). I found suggestive Robert Kidder's contrast of "external" and "internal" law in India, drawing on Victor Li's distinction of external and internal models of law in modern China. Kidder, Western Law in India: External Law and Local Response, in Social System and Legal Process: Theory, Comparative Perspectives, and Special Studies 155-80 (San Francisco, Jossey-Bass Publishers, H. Johnson ed., 1978); Li, Evolution and Development of the Chinese Legal System, in China: Management of a Revolutionary Society 221-55 (Seattle, University of Washington Press, M. Lindbeck ed., 1971). Sally Moore's discussion of "semi-autonomous social fields" suggests how this indigenous law is entwined with official law. Moore, Law and Social Change: The Semi-Autonomous Social Field as an Appropriate Object of Study, 7 LAw \& SOCIETY REVIEW 719-46 (1973).

34 The term "indigenous" is used here as a relative one. Since indigenous systems frequently incorporate cultural elements from the official law and since their sanctioning systems are often entwined with the official ones, no dichotomous distinction can be made. (The customary element in the working of state legal institutions is pointed out in Fuller, Human Interaction and the Law, 14 The American Journal of Jurisprudence 1-36 (1969).) One should imagine a scale with pure types at either end. At the official "exogenous" end might be formal written rules remote from everyday understandings, enunciated by trained specialists, enforced by governmental coercion. At the indigenous end would be simple (?) rules, close to everyday perceptions, applied by non-specialists, internalized by the participants and enforced by diffuse social pressure.

Location on such a scale cannot be ascertained from institutional labels. Consider arbitration in the United States: labor arbitration in a setting of continuing relations and applying "the law of the shop" is closer to the indigenous end than commercial arbitration by ad boc arbitrators from the American Arbitration Association, and the latter is closer to the indigenous end than arbitration of tort cases under the auspices of a court. See Getman, supra note 20.

35 Social life is full of regulation. Indeed, it is a vast web of overlapping and reinforcing regulation. How then can we distinguish "indigenous law" from social life generally? Consider, for example, the kinds of regulatory order that are involved in dating, the exchange of Christmas gifts, behavior in elevators and in classrooms. In each there are shared norms and expectations about proper behavior; violations are visited with sanctions ranging from raised eyebrows to avoidance to assaults, reputational or physical. Clearly, there is some sort of regulation going on here. In spite of the continuities, it may be useful to have a cut-off point further "up" the scale to demarcate what we want to describe as "law" of any sort, indigenous or 
One of the striking features of the modern world has been the emergence of those institutional-intellectual complexes that we identify as national legal systems. Such a system consists of institutions, connected to the state, guided by and propounding a body of normative learning, purporting to encompass and control all the other institutions in the society and subject them to a regime of general rules. ${ }^{36}$ These complexes consolidated and displaced the earlier diverse array of normative orderings in society, reducing them to a subordinate and interstitial status. ${ }^{37}$

Of course, these other orderings continue to exist. Counterparts or analogs to the institutions, processes and intellectual activities that are located in national legal systems are to be found at many other locations in society. Some of these lesser legal orders are relatively independent - institutionally and intellectually - of the national legal system; others are dependent in various ways. That is, societies

otherwise. (Even though, as Nadel points out, the operative controls at any point on the scale are likely to be the internalization and reciprocities that characterize the less organized end of the scale. Nadel, Social Control and Self-Regulation, 31 Social Forces 265-73 (1953).)

The scale that I visualize is one of the organization and differentiation of norms and sanctions. As we move up, we get standards that are more explicit, more deliberation about their application, eventually some kind of procedure for deliberation about norms and their application that can be identified as distinct from the ordinary flow of activity in the field. This procedural separation may range from barely distinguishable bracketing of activity to elaborated provision for tribunals which are separate in time, place, personnel, and formality from the ongoing activity. See Abel, A Comparative Theory of Dispute Institutions in Society, 8 LAw \& Society Review 217-347 (1974). This separation is associated with the appearance of "extrinsic" controls (i.e., the presence of rewards and punishments apart from those intrinsic to the primary activity). See Spiro, Social Systems, Personality, and Functional Analysis, in Studying Personality Cross-Culturally 93-128 (Evanston, Ill., Ros, Peterson \& Co., B. Kaplan ed., 1961). The differentium is the introduction of a second layer of control - of norms about application of norms - along the lines of Hart's identification of law with the union of primary and secondary rules and Bohannon's identification of law with the reinstitutionalization of norms. H. HART, The Concept of LAw (Oxford, Clarendon Press, 1961); Bohannon, The Differing Realms of Law, 67 American Anthropologist, No. 6, at 33-42 (special publication, L. Nader ed., Part 2, 1965), reprinted in Law and Warfare: Studies in the Anthropology of Conflict $43-56$ (Garden City, N. Y., The Natural History Press, P. Bohannon ed., 1967). (The present view departs from Bohannon by including as law secondary controls that appear without removal to a separate institutional location).

Although the principle seems to me a coherent one, it does not lead to a specification of what "is" and what is not law, for the features that we refer to exist across a whole spectrum of intermediate cases, like the transition from blue to purple. Just where to draw the line depends on the particular purpose at hand. Because the point in this section is the pervasive presence of formidable controls located within the activity being regulated by the official law, I have used the term indigenous law in a more sweeping fashion than would be appropriate for other purposes.

${ }^{36}$ Galanter, The Modernization of Law, in Modernization: The Dynamics of Growth 153-65 (New York, Basic Books, M. Weiner ed., 1966).

37 See M. Weber, Max Weber on Law in Economy and Society 140 et seq. (Cambridge, Harvard University Press, M. Rheinstein ed., 1954). 
contain a multitude of partially self-regulating spheres or sectors, ${ }^{38}$ organized along spatial, transactional or ethnic-familial lines ranging from primary groups in which relations are direct, immediate and diffuse to settings (e.g., business networks) in which relations are indirect, mediated and specialized.

The mainstream of legal scholarship has tended to look out from within the official legal order, abetting the pretensions of the official law to stand in a relationship of hierarchic control to other normative orderings in society. Social research on law has been characterized by a repeated rediscovery of this other hemisphere of the legal world. ${ }^{39}$ This has entailed recurrent rediscovery that law in modern society is plural rather than monolithic, ${ }^{40}$ that it is private as well as public in character and that the national (public, official) legal system is often a secondary rather than a primary locus of regulation. ${ }^{41}$ Once we put aside the notion that law is typically public,

38 Social research on law contains a number of conceptual formulations which contribute to our ability to visualize the relationship between the public official legal system and the lesser, partially self-regulating orderings. We distinguish law and morals, public and private spheres, formal and informal processes. Each of these formulations illuminates something of this relationship; none is entirely serviceable. The distinction of law from custom or morality carries in its train a history of conceptual struggles over the meaning of law. Discussions of private as opposed to public legal systems contain valuable insights. P. SELzNick, supra note 30; Evan, Public and Private Legal Systems, in Law and Sociology 165-84 (New York, The Free Press of Glencoe, W. Evan ed., 1962). But the public-private distinction invites us to categorize where we need to measure variation. Much of the same may be said of the invoked and rarely defined distinction between formal and informal, which collapses into an amorphous mass, a vast and changing array of processual and structural characteristics.

Moore uses the term "semi-autonomous social fields" to refer to areas of social life that

can generate rules and customs and systems internally, but that [are] also vulnerable to rules and decisions and other forces emanating from the larger world by which it is surrounded. The semi-autonomous social field has rule-making capacities, and the means to induce compliance; but it is simultaneously set in a larger matrix which can, and does, affect and invade, sometimes at the invitation of persons inside it, sometimes at its own instance.

Moore, supra note 33 , at 720 . This formulation usefully points to the study of the lesser normative orderings, not as isolated and independent units, but as parts of a larger, complex legal order, with which they interact.

39 This rediscovery is often associated with Eugen EHrLICH, supra note 33 (first published in 1913). See also M. WeBER, supra note 37 (first published in 1922), at 16-20, 140-49.

40 The plural or multiple character of law in a given society has been noted by Fuller and by Pospisil. L. Fuller, The Morality of Law 123 et seq. (New Haven, Yale University Press, revised ed., 1969); L. Pospisil, Anthropology of Law: A Comparative Theory 343 (New York, Harper and Row, 1971). The latter assumes that legal regulation is isomorphic with group structure. I submit that it is important to regard the relation of groups and legal regulation as problematic.

${ }^{41}$ The secondary, derivative "back up" character of law is suggested by Bohannan (supra note 35), but his identification of law with the reinstitutionalization of norms seems to posit a constant relationship between primary and secondary controls. Again, I think it is important to regard the relation between primary and secondary controls as problematic. See the notion of law as the union of primary and secondary rules in H. HART, supra note 35. 
unified and direct in its operations, we can formulate the question of access to justice in terms of relations between the big (public, national, official) legal system and the lesser normative orderings in society that I have called "indigenous law." These relations are obscured by the portrayal of the big system as all-encompassing, exclusive and controlling. ${ }^{42}$ But this notion of official law as a comprehensive monolith - and indeed as a "system" - is not a description of it, but rather part of its historic ideology. Legal regulation in modern societies, as in others, has a more uneven, patchwork character. ${ }^{43}$

The legal centralist disdain of these lesser orderings is matched by the view that they have been so attenuated by the growth of the state and/or the development of capitalism that their presence is vestigial or confined to backwaters. ${ }^{44} \mathrm{I}$ would submit that indige-

42 The difficulty of seeing how these parts are related is compounded by our tendency to view them as related in evolutionary sequence. The evolutionary view is that lesser, dispersed and informal regulatory elements are displaced or transformed by the growth and elaboration of the centralized bureaucratic legal system. See Parsons, Evolutionary Universals in Society, 29 American Sociological Review $339-57$ (1964). Curiously, Diamond's depiction of state law relentlessly exterminating custom provides a mirror image of the evolutionary view with the value signs reversed. Diamond, The Rule of Law Versus the Order of Custom, 38 Social RESEARCH 42-72 (1971).

43 See Tanner, Disputing and the Genesis of Legal Principles: Examples from Minangkabau, 26 SOUtHWESTERN Journal of ANTHRopology 375-401 (1970).

44 That indigenous law has been effaced and the implications of that for the centrality of official law and the leadership of legal professionals is argued in G. SAwER, LAw IN SOCIETY (Oxford, Clarendon Press, 1965):

But there is a false assumption underlying a good deal of the thought which assigns a secondary or derivative role to law, whether state law or juristic law or both. It is the assumption that on all relevant matters or at least on most of them there is a positive, strongly held view among the people at large or among the people making up a relevant sub-group; that there is a folkway, or a law that is lived with conviction, or a sub-stratum, to which determining force can be attributed. In fact, over the vast range of matters with which the law-ways and the state-ways of a modern country are concerned, the attitudes of the folk to particular laws can vary from passionate or sullen hostility to enthusiastic support; in between are various degrees of divided views, conflicting practices, puzzlement, indifference, or inability to understand. It is an accepted function of leadership in the community to initiate proposals for the amendment of existing law, or the introduction of new law, or to exploit possibilities of adaptation which existing law provides by reason of dormant principles or generality of statement or fresh combinations of concepts. The role of giving this sort of lead is usually divided between the lawyers and courts, and the other organs of government; the former deal with lawyers' law, the latter with all branches of law. It is not necessary that the folk should enthusiastically support a law; it is enough that they are not violently opposed. This leaves a large area in which the initiative can come from within the law-ways or state-ways. A law thus initiated will still not be effective unless most of those concerned observe it, but this can be mainly a question of communication, explanation, persuasion, and an efficient enforcement process to deal with deviants and provide an example to the rest.

Id. at 186. 
nous and official ordering may not be mutually exclusive (or historically serial) and that modern society proliferates both. Institutions of official regulation themselves become the site of indigenous ordering - e.g., the informal rules of the government enforcement agencies studied by Blau, ${ }^{45}$ which determined which official rules were enforced and to what extent. I find suggestive Stinchecombe's challenge of the intellectual cliché that communal relations deteriorate with the increase of formal, impersonal and technical social regulations. ${ }^{46} \mathrm{He}$ argues that community (defined in terms of solidarity, socialization and "a tendency to solve disputes within the group by standards of justice and need rather than standards of game theory" ${ }^{47}$ ) is enhanced rather than undermined by formal organization.

[T] he solidarity of communal groups is intimately dependent on their degree of formal organization. Formal organizations aid in making the environment of primary groups homogeneous, protect small-group integrity, and aid in preserving their solidarity by normative control of exploitation. They can be agents of the groups as a whole whose fate can be interpreted as group fate, they organize supralocal socialization experiences, and they provide support for cultural elites of the group. ${ }^{48}$

The survival and proliferation of indigenous law in the contemporary United States remains concealed from those who are looking for an inclusive and self-contained Gemeinschaft, unsullied by formal organization, which enfolds individuals and integrates their whole life experience. What we find instead is a multitude of associations and networks, overlapping and interpenetrating, more fragmentary and less inclusive. For the most part, they are, as Danzig and Lowy observe, 49 "socio-economic networks rather than bounded groups." Such partial communities, linked by informal communications and sometimes by formal communication devices as well, provide much of the texture of our lives in family and kinship, at work and in

45 P. Blau, The Dynamics of Bureaucracy: A Study of Interpersonal Relations in Two Government Agencies (Chicago, University of Chicago Press, revised ed., 1963).

46 Stinchcombe, Social Structure and Organizations, in HandBook of Organizations 142-93 (Chapter 4), at 185 et seq. (Chicago, Rand McNally \& Co., J. March ed., 1969).

47 Id. at 186.

48 Id. at 191.

49 Danzig \& Lowy, Everyday Disputes and Mediation in the United States: A Reply to Professor Felstiner, 9 Law \& Society Review 675-94, at 681 (1975). 
business dealings, in neighborhood, sports, religion and politics. There are varying degrees of self-conscious regulation and varying degrees of congruity with the official law. This is a realm of interdependence, regulated by tacit norms of reciprocity and sometimes by more explicit codes. The range of shared meanings is limited, but the cost of exit is substantial. If we have lost the experience of an all-encompassing inclusive community, it is not to a world of arm's length dealings with strangers, but in large measure to a world of loosely joined and partly overlapping partial or fragmentary communities. In this sense our exposure to indigenous law has increased at the same time that official regulation has multiplied.

Mookin and Kornhauser's analysis of "bargaining in the shadow of the law" in divorce cases helps us to put aside the centripetal view and to focus on the movement of law out from the forum into private ordering. The policy lesson they draw is that the "primary function of the legal system should be to facilitate private ordering and dispute resolution." 50 But the divorce example imparts a highly individualistic coloring to the analysis: private ordering is equated with the parties "making law for themselves" in the light of their "preferences" and "the law." But our discussion of indigenous law suggests that private ordering may involve more than disputants devising an ad boc legal regime for themselves. The parties may not constitute an isolated dyad, but may be embedded in (or adhere to) a group or network with its own rules and standards. Making claims on the basis of what is acceptable quality in a trade, invoking "academic freedom," or submitting a dispute to an arbitrator are not comfortably subsumable under the notion of "making law for themselves." Each of these is as much an act of affiliation as of legislation; it is a reference to some existing normative structure, not a proposal to erect a new one. Working out a corpus juris and constituting a legal establishment are relatively infrequent kinds of behavior (and rarely begin from scratch); most of our justice-seeking is by adhesion.

Where bargaining and regulating take place in the settings of patterned norms and sanctions that we have called "indigenous law," we may be inclined to characterize the whole system somewhat differently. Mnookin and Kornhauser's image of "bargaining in the shadow of the law" suggests that the law is there and the disputants

50 Mnookin \& Kornhauser, supra note 7, at 986. 
meet in a landscape naked of normative habitation (or in which such structures are subsumed into their "preferences"). Instead, I visualize a landscape populated by an uneven tangle of indigenous law. In many settings the norms and controls of indigenous ordering are palpably there, the official law is remote, and its intervention is problematic and transitory (e.g., the businessmen described by Macaulay ${ }^{51}$ or a typical dispute within a university). In such settings the relation might be better depicted as "law in the shadow of indigenous ordering." 52

The relation of official law to indigenous ordering is not invariably a matter of mutual exclusion (where the former ousts the latter), nor one of hierarchic control (where the latter is conformed to or aligned with the former). Judicial intervention to apply official standards does not necessarily weaken indigenous controls. For example, Zald and Hair suggest that the judicial erosion of the doctrine of charitable immunity and the exposure of hospitals to liability for negligence provided enlarged "incentives and sanctions ... to governmental and private standard-setting bodies such as the Joint Commission [on Accreditation of Hospitals] to induce compliance with standards on the part of hospitals." 53 Similarly, Macaulay shows that official intervention in the relation between automobile manufacturers and their dealers led to a growth of internal regulation rather than its attenuation. ${ }^{54}$ And Randall's study of movie censorship reveals how the elaboration of internal controls within the movie industry was a reflex to actual (and potential) control by the official law. ${ }^{55}$

I am not trying to turn legal centralism upside down and place

51 Macaulay, supra note 24. that:

52 This indigenous ordering in turn may be a derivative of bargaining. Getman observes

Collective bargaining shapes labor arbitration and gives it power. ... It is only when unions are powerful, well established and responsive to the needs of their members that labor arbitration works successfully.

Getman, supra note 20, at 917 . In this setting we get "law in the shadow of [collective] bargaining."

53 Zald \& Hair, The Social Control of General Hospitals, in ORganization Research ON Health Institutions 51-81 (Ann Arbor, Institute for Social Research, University of Michigan, B. Georgopoulos ed., 1972).

54 S. Macaulay, Law and the Balance of Power: The Automobile Manufacturers and Their Dealers (New York, Russell Sage Foundation, 1966).

55 R. Randall, Censorship of the Movies: Social and Political Control of a Mass Medium (Madison, University of Wisconsin Press, 1968). 
indigenous law in the position of primacy. Instead, I suggest that the relation of official and indigenous law is variable and problematic. Just as the character of indigenous regulation is affected in unanticipated ways by developments in the official law, so the presence of indigenous regulation may transform the meaning and effect of the official law. ${ }^{56}$

\section{Access to Justice in a Post-Centralist World: A Dialogue of Shadows}

In Part I, I argued that the most significant legal traffic was the centrifugal flow of legal signals rather than a centripetal flow of cases into official forums. In Part II, I argued that these signals radiate into spaces that are not barren of normative ordering; instead, the social landscape is covered by layers and centers of indigenous law. What then are the bearings for "access to justice" inquiry and action in a world of centrifugal flows and indigenous ordering?

One reaction might be to conclude that what goes on in official forums is not a key determinant of the justice quality of most social relations and transactions. Changes in access to official forums may be far less important determinants of justice than, for example, land reform, provision of free education, or of good roads with buses to allow villagers to escape the domination of the landlord. Such major redistributions of resources and opportunities are unlikely to be accomplished by any rearrangement of forums for disputes. But redis-

56 Katz illuminates the complexity of the interface between external controls and those within organizations. Katz, Cover-up and Collective Integrity: On the Natural Antagonisms of Authority Internal and External to Organizations, 25 Social Problems 3-17 (1977). Compare the observations of students of indigenous tribunals about the invocation of official law as a "doomsday machine" to induce compliance with the indigenous system. In his study of a Brazilian squatter settlement, Santos finds that:

The official legal system is presented not as a forum to which a litigant may appeal from an adverse decision under Pasargada law but as a threat aimed at reinforcing the decision of the RA [Residents' Association] under that law.

Santos, The Law of the Oppressed: The Construction and Reproduction of Legality in Pasargada, 12 LAw \& Society Review 5-126, at 79 (1977). Similarly, Meschievitz describes an instance in which a Nyaya Panchayat (Indian statutory village tribunal), chronically unable to enforce its decrees, collected a fine from some notorious and threatening criminals when the Sarpanch argued that if they did not pay a fine of some sort "the other party would surely appeal [to the regular courts] and ... once in the hands of the police and state courts, there was no way of knowing the possible repercussions for the offenders." C. Meschievitz, Whither Nyaya Panchayats (unpublished paper, 1979). 
tributive reforms are not self-executing. They bring in their train problems of enforcement and disputes about entitlements; and presumably they would enlarge the capability of those benefited to carry on all kinds of disputes. Even if dispute institutions are not determinative of the basic contours of justice in society, it does not follow that they are not worthy of the attention of those who seek to increase access to justice.

The persistence of indigenous law might provoke two disparate responses, one based on acute sensitivity to its deficiencies, the other on a lively sense of its promise. Indigenous law is not always the expression of harmonious egalitarianism. Indigenous law often reflects narrow and parochial concerns; it often is based on relations of domination; protections that are available in public forums are absent. The presence of indigenous law, then, is reason to redouble our efforts to project official legality into all corners (while reforming it to actualize its promise of fairness to all). ${ }^{57}$ Much has been said over the years about the costs and limitations of such programs of legalization. Indeed, much of the access to justice movement has been concerned with finding viable ways to reduce the expense, formality, cumbersomeness, delay and other features that make legalization worrisome or less than optimal.

The second response turns away from differentiated legal structures in an attempt to, putting it crudely, replace official law by (improved, purified) indigenous law. Proposals to do this by (re)constituting tribunals that give genuine expression to community values and operate in a way that is familiar and accessible are found in industrialized countries as well as in developing ones. At least some of these schemes turn out to be dismal failures: thus, the Nyaya Panchayats promoted by India in the 1950's and 1960's seem to be moribund. ${ }^{58}$ This may be due to problems of design and execution

57 Rubenstein, very much alert to the ways in which informal non-adjudicatory processes may undermine procedural and substantive rights, proposes to enlarge the responsibilities and capacities of courts (e.g., to investigate and frame the issues) while restricting the pre-trial role of lawyers, so that adversary proceedings with due process can be preserved while eliminating the differential distribution of advantages that flow from its present institutional characteristics. Rubenstein, Procedural Due Process and the Limits of the Adversary System, 11 Harvard CiviL Rights-Civil Liberties Law Review 48-96 (1976).

58 Baxi \& Galanter, Panchayat Justice: An Indian Experiment in Legal Access, in Access to Justice: Emerging Issues AND Perspectives 341-86 (Alphen aan den Rijn/Milan, Sijthoff and Noordhoff/Giuffrè, Vol. III of the Florence Access-to-Justice Project Series, M. Cappelletti \& B. Garth eds., 1979); see Galanter, The Aborted Restoration of "Indigenous" Law in India, 14 Comparative Studies IN SOciety and History 53-70 (1972). 
rather than to any defect in the fundamental conception. But the failure of many "alternative" forums to recruit cases (other than by referral from coercive official agencies) suggests that there may be formidable problems of designing a tribunal that meshes with community needs. ${ }^{59}$ But rather than dwell on losers, let us consider a success story. The Polish Social Conciliatory Commissions (SCC's) studied by Kurczewski and Frieske ${ }^{60}$ present an attractive instance of a tribunal that is used by its constituency, operates without coercion, and gives expression to community values. This example of "self-government in justice," as the authors call it, is as good an instance of officially-sponsored "indigenous law" as we are likely to see. But even with the SCC experience in mind, several limitations seem to be inherent in the indigenous law model.

Indigenous law like other law has the problem of connecting effective sanctions to its determinations. Where coercive powers are renounced (as by the SCC's), the indigenous tribunal faces the

59 Thus, the San Jose Neighborhood Small Claims Court, which attempted to reach out by hours, location, publicity and informality, produced only 60 filings in a six-month period. Beresford \& Cooper, A Neighborbood Court for Neighborbood Suits, 61 Judicature 185-90, at 190 (1977). The much-studied Dorchester mediation project produced fewer referrals from all sources than the 40 cases per month anticipated by its planners. Snyder, Crime and Community Mediation - The Boston Experience: A Preliminary Report on the Dorchester Urban Court Program, 1978 Wisconsin Law Review 737-95, at 761.

Observers blame the low rate of referrals from official sources on such problems as police fear of losing overtime benefits associated with court appearance. D. MC Gillis \& J. MuLlen, Neighborhood Justice Centers: An Analysis of Potential Models 98 (Washington, D. C., Department of Justice, Office of Development, Testing and Dissemination, National Institute of Law Enforcement and Criminal Justice, LEAA, 1977). Nevertheless, the scanty intake is reminiscent of the disappearing caseload problem that besets other "alternative" tribunals. Thus, Baxi and Galanter (supra note 58, at 368 et seq.) found that the filings in the Nyaya Panchayats in Uttar Pradesh fell to a tenth of their original number in the course of 20 years. A similar decline in the civil proceedings heard by the Schiedsmann is depicted in Bierbrauer, Falke \& Koch, Conflict and Its Settlement: An Interdisciplinary Study Concerning the Legal Basis, Function and Performance of the Institution of the Schiedsmann, in Access TO Justice: Promising Institutions 39-101, at 47-49 (Alphen aan den Rijn/Milan, Sijthoff and Noordhoff/Giuffrè, Vol. II of the Florence Access-to-Justice Project Series, M. Cappelletti \& J. Weisner eds., 1978). For an account of dissatisfaction with an arbitration experiment in Massachusetts in the 1780's, see M. Bloomfield, American Lawyers in a Changing Society: 1776-1876, at 57 et seq. (Cambridge, Harvard University Press, 1976). The lessons of shrinkage and desuetude remain to be drawn.

Apart from all the problems of articulating the tribunal to the community, the push for tribunals may misread public need. Alternative institutions usually address the problem of providing good decisions rather than favorable endowments for bargaining or regulation. It may be that there is no shortage of forums, but rather a shortage of good endowments for disputing and that the "regular courts" are better at producing such endowments than such special institutions. In a similar vein, an optimistic reading might be that these institutions are by their very presence producing favorable endowments (and thus anticipatory resolution of disputes, etc.), and their low caseload should be taken as an indication of success rather than failure.

${ }^{60}$ Kurczewski \& Frieske, supra note 25. 
problem of obtaining leverage over those who are impervious to community opinion, getting them to submit to its jurisdiction or to comply with its decisions.

This is compounded where the setting is culturally heterogeneous. Those who share a common location or common interests (e.g., as workers or students) may not share a common culture. Ideas about deference, noise, work performance, child rearing and so forth may differ among those who interact frequently. The thrust of community law is limited when moral communities are plural and crosscutting, not self-contained and reinforcing.

And the most crucial disputes may not be within the community, but with entities that are separated not merely by pluralism, but by difference in form and scale. The most significant transactions giving rise to a sense of injustice may be with corporate entities - government departments, corporations - that are not amenable to community persuasion or sanction. ${ }^{61}$ Indeed, a defining characteristic of our age is the extent to which transactions and disputes are between units of different scale. 62

Anxiety about whether indigenous law can be effective is accompanied by some worry that it may sometimes be too effective. The coerciveness of unorganized community action tends to be indiscriminate and difficult to calibrate. ${ }^{63}$ Not all communities are harmonious and egalitarian, and in many settings indigenous law flourishes in association with repulsive disparities of power. Indigenous law may by definition have the virtues of being familiar, understandable, and independent of professionals. But a wholesale embrace of indigenous law would be insufficiently critical because it would support arrangements of domination and exploitation as well as participatory, democratic ones. Thus, if our program is one of

61 This is identified as the "most serious flaw in the concept of 'informal' dispute-settlement procedures" for consumer grievances in Eovaldi \& Gestrin, Justice for Consumers: The Mechanism of Redress, 66 NORTHWESTERN LAw REview 281-325, at 306 (1971).

62 See J. Coleman, Power and the Structure of Society (New York, W. W. Norton \& Co., 1974); see S. Moore, Law as Process: An Anthropological Approach, at Chapter 3 (London, Routledge \& Kegan Paul, 1978). On the dominance of official dispute institutions by cases between units of different scale, see Galanter, Afterword: Explaining Litigation, 9 LAW \& Society REview 347-68 (1975); Wanner, The Public Ordering of Private Relations: Part I: Initiating Civil Cases in Urban Trial Courts, 8 LAw \& SocIETY Review 421-40 (1974). On the effects of this disparity, see Galanter, supra this note; Galanter, supra note 17.

63 See Nadel's observation (supra note 35, at 271) that the move from diffuse to specific controls serves to moderate punishments and make them compatible with rehabilitation and continued coexistence. 
protecting and empowering people in their social settings, the establishment of tribunals or forums for the application of indigenous community law is, at best, an incomplete program.

If neither end of the spectrum seems an attractive destination, can we find a way to go in both ways at once - or to enjoy "here" more? We reach the platitudinous call for a creative synthesis. If neither dismantling official law nor absorbing indigenous law into it seems a feasible or attractive program, is there some way for them to enrich each other, to offset each other's weaknesses? Dialogue or interaction or a "middle way" is easy to call for, but hard to portray. I want to sketch some lines of research and some possibilities for policy that seem implicated in such a middling course.

We may underutilize existing sources of insight, for our professional habits of mind disincline us to take indigenous law seriously as a locus of value rather than as raw material to be reshaped, controlled, displaced or tamed by real law. ${ }^{64}$ But the relation of law to other normative orderings has been central to many thoughtful explorations of social order from ancient times to the present. Every legal system has to address the problem of the autonomy and authority of the various other sorts of normative ordering with which it coexists in society. The big legal system faces the question of how to recognize or supervise or suppress the little systems. Legal centralism is one style of response to this generic question of legal ordering, and its exhaustion suggests the need for reflection on other models. ${ }^{65} \mathrm{My}$ suspicion that the historical and comparative experience is rich and varied is bolstered by the fact that my own very limited exposure produces a set of disparate examples.

The self-conscious appraisal and design of the relation between competing normative orders is most vividly apparent in the relation of the state to religion, where the law's rival may be a corpo-

${ }^{64}$ Indeed, our habits may prevent us from seeing it all, as Fuller suggests:

... it is not a question of our being unfamiliar with customary law, but of our being quite unable to draw on our own experience ... [i]n part ... because we do not know we have it. For it is characteristic of customary rules of action that they disappear from view precisely when they are most effective, when they appear not as rules at all, but simply as apt responses to an immediate reality, as part of "the way things are."

Fuller, The Law's Precarious Hold on Life, 3 Georgia Law Review 530-45, at 540.

${ }_{65} \mathrm{~J}$. Griffiths, supra note 32. 
rate institution with its own learned tradition expounded by its own specialists (and even with its own doctrines about its relationship to state law). In Western tradition, the theme of "church and state" is the locus classicus of thinking about the multiplicity of normative orders. There is an abundance of prescriptive theories about how religious law should be treated by the big legal system ${ }^{66}$ (and vice versa) and a rich literature depicting instances of conflict and coexistence.

Other legal systems have conceived the relationship of their components very differently. Classical Hindu law, to take an example that I happen to have encountered, can be read as a contrasting method of combining the most refined and professional elements with lay and unlettered ones. Not only did the textual law lay down different rules for different kinds of persons, but it incorporated and certified many bodies of rules not found within its pages. Every aggregation of people - corporations of traders, guilds of artisans, castes, families, sects, villages - was entitled to formulate and apply its own customs and conventions. When matters concerning such groups came before the royal courts, they were to be decided in accordance with the usage of the group. (Such custom was not necessarily ancient, nor was it unchangeable. The power of groups to change custom and create new obligatory usage was generally recognized.) The king was advised that in cases of disputes among traders, artisans, husbandmen, sectarians and so forth, it was impossible for outsiders to give correct decisions: those who understood their conventions were to be invited to render a decision; ${ }^{67}$ provision was made for cases to be decided outside the king's court by assemblies of the guild, locality, caste, etc. Each group was entitled to receive royal recognition and enforcement of its usages, and the more refined and, concededly, elevated textual law was applied where disputants were not covered by some common body of customary law. 68

66 These range from state suppression of religious law, through various forms of intervention, limitation, recognition, and application, to religious control over state law. An example of contention among these modes in contemporary India, accompanied by a sketch of some of the dimensions involved in creation of such a taxonomy, are found in Galanter, Hinduism, Secularism and the Indian Judiciary, 21 PHILOSOPHY EAST AND WEST 467-87 (1971).

67 P. Kane, History of Dharmasastra: Ancient and Mediaeval Religions and Civil LAw, Vol. III, 284 (Poona, Bhandarkar Oriental Research Institute, 1946).

${ }^{68}$ Id. Vol. III at 283. 
Hindu rulers traditionally enjoyed and sometimes exercised a general power of supervision over all these lesser tribunals. But there was not systematic imposition of "higher law" on lesser tribunals. There was a general diffusion by filtering down (and occasionally up) of ideas and techniques and by conscious imitation. The relation of the "highest" and most authoritative (textual and royal) elements of the legal system to the lesser (local and customary) elements was not one of bureaucratic superior to subordinate. It was perhaps closer to the relations that obtain between high fashion designers and American department store fashions or between our most prestigious universities and our smaller colleges than to the hierarchic control we associate with law. ${ }^{69}$

These remote examples are not invoked to point to some preferred state of affairs, but to suggest that not every elevated and complex body of law sees itself as superseding and displacing lesser orderings; styles (and theories) of coexistence vary. Since we have tended to neglect indigenous law, attention to these remote historic and comparative instances may provide useful leads for our understanding and help us to visualize some of the possibilities that surround us. To dispel any implication that the question is esoteric and is not found at the heart of modern law, I want to give a final example from contemporary American commercial law.

The drafting of the Uniform Commercial Code was a self-conscious attempt (by Karl Llewellyn) to synthesize formal law and commercial usage: the formal law would incorporate the best commercial practice and would, in turn, serve as a model for the refinement and development of that practice. ${ }^{70}$ The Code's broadly drafted rules would be accessible to businessmen and would provide a framework for self-regulation which would, in turn, furnish attentive courts with content for the Code's categories. Thus, the Code would serve as a vehicle for business communities to evolve law for

69 J. Derrett, Religion, Law and the State in India, at Chapters 6-7 (London, Faber and Faber, 1968); Galanter, The Displacement of Traditional Law in Modern India, 24 Journal of Social Issues 65-91. On different readings of this Hindu tolerance of the lesser legal orders, see J. Derrett, supra this note, at Chapter 7; R. Lingat, The Classical Law OF India 176 et seq. (Berkeley, University of California Press, J. Derrett transl., 1973).

70 Thus, the Code announces among its underlying purposes "to permit the continued expansion of commercial practices through custom, usage and agreement of the parties" ( $\S$ $1-102(2)(b))$. Usage of trade is embraced as a source for interpreting agreements ( $\$ 1-205)$, and custom is viewed as supplementing the law rather than derogating from it. See, e.g., Comment 4 to sec. $1-205$. 
themselves in dialogue with the courts, operating not as interpreters of imposed law but as articulators and critics of business usage. ${ }^{71}$ There has been no evaluation of the Code's attempt to institute such a synergistic relationship. ${ }^{72} \mathrm{I}$ admit to some skepticism because the Code seems to misread the character of commercial litigation (i.e., the extent to which it is shaped by non-rule elements such as costs and the relations between the parties) and its relation to business usage. ${ }^{73}$

The insights afforded by historical and comparative study have to be linked to an enlarged understanding of the working of indigenous regulation in contemporary American society. Systematic exploration of "indigenous" law requires that we ask under what conditions and in what locations does self-regulation emerge? What are the features that it displays? Is there explication of norms, formality of procedure, broad or narrow participation, etc.? The social settings in which such regulation takes place are not independent self-contained units, but interact with a larger complex legal order. How, then, is indigenous regulation related to the regulation projected by the big legal system? What is the relationship between official law and the indigenous regulatory activity? Does the latter rely on or borrow from the norms, sanctions and style of the official law? The existing literature contains reports on indigenous law in various settings. ${ }^{74}$

71 On the linkage between this and Llewellyn's jurisprudence, see W. TwINING, KarL Llewellyn and THE Realist Movement, at Chapters 11-12 (London, Weidenfeld and Nicolson, 1973). Twining notes (id. at 312) that "Llewellyn's attitude to commercial usage has echoes in Ehrlich," by whom he had been influenced during his early sojourn in Germany. A fascinating parallel may be found in Llewellyn's contemporaneous (c.1947) draftsmanship of an even more purely customary code for the Santana Pueblo, reprinted by Twining (id. at 549).

72 An attempt by White to evaluate the working of art. 2 does not identify this as a goal. White, Evaluating Article 2 of the Uniform Commercial Code: A Preliminary Empirical Expedition, 75 Michigan Law Review 1262-85 (1977). Although it does not go beyond the reported appellate cases for data on impact, it does suggest a profound dissociation of appellate judicial doctrine from business practice. It does present one finding that might be interpreted as an indication of success in these terms: a decrease in appellate litigation in an area where the older law turned on intricate determinations of title that were alien to business understanding and "the drafters of the Code gave legal meaning to the symbols [C.I.F., etc.] routinely used by businesspersons." Id. at 1275 . Llewellyn's notions about the relation of decisional styles of courts to commercial practice were explored by Carpenter, in Note, How Appellate Opinions Should Justify Decisions Made Under the U.C.C., 29 STanford Law Review $1245-82$ (1977). An admittedly small and unsystematic sample of appellate cases failed to reveal any noticeable shift toward incorporation of merchants' views in judicial doctrine.

73 See Macaulay, supra note 24; L. Friedman, Contract Law in America (Madison, University of Wisconsin Press, 1965); Friedman \& Macaulay, Contract Law and Contract Teaching: Past, Present and Future, 1967 Wisconsin LAw Review 805-21 (1967).

74 The literature includes reports on self-regulation in a variety of business settings, such as shopping centers (Mac Collum, Dispute Resolution in an American Supermarket, in LAw 
These reports display the immense profusion and variety in which these "semi-autonomous social fields" exist in a single society. From them I conclude that any major advance in our understanding of how official legal regulation works will depend on knowing more about indigenous law.

Study of the spheres of indigenous ordering leads to exploration of their interface with official forums. How do courts (and other official agencies) supervise and control bargaining and regulation in various social settings? A promising place to begin would be with judicial postures toward bargaining among disputants in their courts. ${ }^{75} \mathrm{~A}$ preliminary scanning of the literature presents a striking contrast between the elaboration of formal procedures (preliminary hearings, fairness hearings, appellate review) in cases where there is formal judicial participation (e.g., in class actions in the Federal

AND WARFARE, supra note 35, at 291-99), trade associations (Mentschikoff, Commercial Arbitration, 61 Columbia LAw REview 846-69 (1961)), heavy manufacturing (Macaulay, supra note 24), textiles (Bonn, Arbitration: An Alternative System for Handling Contract Related Disputes, 17 Administrative Sciences Quarterly 254-64 (1972)); Bonn, The Predictability of Nonlegalistic Adjudication, 6 LAw \& Society REview 563-78 (1972)), the garment industry (Moore, supra note 33), movie distribution and exhibition (R. RaNDall, supra note 55), autodealers' relations with manufacturers (S. MACAULAY, supra note 54), and with customers (Whitford, Law and the Consumer Transaction: A Case Study of the Automobile Warranty, 1968 Wisconsin LAw REviEw 1006-98). In addition, there are reports on self-regulation within religious groups (e.g., Note, Rabbinical Courts: Modern Day Solomons, 6 Columbia Journal of Law and Social Problems $49-75$ (1970)), ethnic communities (e.g., Doo, Dispute Settlement in Chinese-American Communities, 21 American Journal of Comparative Law 627-63 (1973)), intentional communities (e.g., B. Zablocki, The Joyful Community: An Account of the Bruderhof, A Communal Movement Now in Its Third Generation (Baltimore, Penguin Books, 1971)), professional associations (e.g., Akers, The Professional Association and the Legal Regulation of Practice, 2 LAw \& Societr Review $462-82$ (1968)), athletics (e.g., Cross, The College Athlete and the Institution, 38 Law AND CONTEMPORARy Problems 151-71 (1973)), workplaces (Feest, "Betriebsjustiz": Internal Administration of Justice at the Place of Work, 11 Abstracts on Criminology ANd Penology 6-14 (1971)), and so forth.

In spite of such profusion, the data base is thin and uneven. There is a major problem of comparability among studies done in diverse settings and by diverse methods. This is a problem which flows in part from the immense variety of fields, but it is compounded by the lack of communication and of shared concepts among researchers. Although the literature contains a variety of testable hypotheses, the establishment of grounded theory awaits the adaptation (or development) of adequate methods for the comparative study of these fields.

75 For purposes of mapping out (what appears to be) largely uncharted research territory, the following crude division seems a useful start:

a) Formal judicial participation: i.e., pursuant to a formal judicial responsibility to supervise the settlement - as in class actions, stockholders' derivative suits, bankruptcy reorganization suits, where minors are parties, etc.

b) Implicit formal participation: i.e., where the form of the proceedings requires that the judge ratify the bargain struck by the parties - as in divorce and plea bargaining.

c) Informal participation: i.e., where judges participate in settlement negotiations in the absence of any formal requirement that they supervise the settlement or ratify the results.

d) Non-participation: i.e., where settlement activity among the parties takes place without any of these types of participation by the judge. 
courts) ${ }^{76}$ and the cursory ad boc mediation that prevails where supervision is not mandated (e.g., in many tort and contract cases in those same courts). ${ }^{77}$ How do formally supervised settlements and mediated ones compare with the adjudicated outcomes? ${ }^{78}$ Students of dispute processing have differed in their reading of the relation between negotiated outcomes and adjudicated ones. ${ }^{79}$ Are the norms that govern adjudication given expression in negotiated settlements? What are the consequences of judicial gravitation to the mediator role? ${ }^{80}$ Negotiated outcomes may be viewed not only for their effect on the disputants immediately involved, but also for their general effects: private orderers are not only the receivers of mes-

76 In re General Motors Corporation Engine Interchange Litigation, 594 F.2d 1106 (7th Cir. 1979); Developments in the Law: Class Actions, 89 Harvard LAw Review 1318-1644, at 1536 et seq. (1976); Haudek, The Settlement and Dismissal of Stockholders' Actions - Part Two: The Settlement, 23 SouTHWESTERn LAw Journal 765-819 (1969).

77 Will, Merhige \& Rubin, The Role of the Judge in the Settlement Process, 75 FEDERAL Rules Decisions 89, 203 (1977) (from proceedings of a Seminar for Newly Appointed U. S. District Judges, September 13-18, 1976, Washington, D. C.); Macaulay, Elegant Models, Empirical Pictures, and the Complexities of Contract, 11 LAw \& SocIETY REviEw 507-28, at 507 (1977); Wright, The Pretrial Conference, 28 Federal Rules Decisions 141-58 (1962). See Avakian, How One Trial Judge Settles Cases, 35 Guild Practitioner 15-24 (1978); Title, New Settlement Techniques for the Trial Judges, 18 Judges' Journal $42-49$ (1979); J. Lobenthal, Jr., Power and Put-On: The Law in America (New York, Outerbridge \& Dienstfrey, 1970), at Chapter 9 for comparable patterns in state courts.

78 Similarly, one might compare different plea bargaining regimes. See Mather, Some Determinants of the Method of Case Disposition: Decision-Making by Public Defenders in Los Angeles, 8 LAw \& Society Review 187-216 (1973); Hobbs, Judicial Supervision over California Plea Bargaining: Regulating the Trade, 59 California Law Review 962-96 (1971).

79 The modal view among students of law and society posits a sharp disjunction between norm-governed adjudication on the one hand and bargaining-negotiation on the other. This dualistic view was put forth by Aubert and by Gulliver. Aubert, Competition and Dissensus: Two Types of Conflict Resolution, 7 Journal of Conflict Resolution 26 (1963); Gulliver, Negotiations as a Mode of Dispute Settlement: Towards a General Model, 7 LAw \& SocIETY REVIEW 667-91 (1973). It is questioned from two quite different directions by proponents of greater continuity between dispute processes. On the one hand, Kidder argues that adjudication is best understood as an extension of negotiation-bargaining, providing an arena in which resources and tactics can be arrayed and in which norms are just one more resource. Kidder, Formal Litigation and Professional Insecurity: Legal Entrepreneurship in South India, 9 LAw \& SOCIETY REVIEW 11-37 (1974). On the other hand, Eisenberg finds that dispute negotiation is principled or norm-governed, even more so than formal adjudication in that actors may respond to a wider range of normative commitments than are taken into account in formal adjudication. Eisenberg, supra note 7. But see Caplovitz's finding that only about half of consumer debtors who settled out of court considered the terms of the settlement fair. D. CAPLOvitz, with the assistance of E. Single, Consumers in Trouble: A Study of Debtors in Default 245 (New York, The Free Press, 1974).

80 There seem to be other locations in the American system where actors, whose formal role commitments are part of the adversary game, insist on playing mediator instead. S. Macaulay, Lawyers and Consumer Protection Laws, 14 LAw \& Society Review 115-71 (1979). See Skolnick's observation of the "regression to cooperation" in the criminal court community. Skolnick, Social Control in the Adversary System, 11 Journal of Conflict Resolution 52-70 (1967). 
sages or endowments, but also may be transmitters. A similar series of questions arises about judicial posture respecting indigenous regulatory activity. ${ }^{81}$

Thus, the access to justice question leads us to envision a kind of "impact" research that would depart from the earlier generation of impact research in several important ways. ${ }^{82}$ The older impact research started from the doctrinal pronouncements of appellate courts and asked about congruence between that doctrine and practices of other agencies (lower courts, school boards, police, etc.). We are interested in the effects not only of doctrinal pronouncements, but of costs, remedies, delay, uncertainty, legitimation, stigma and all of the other components of the total message transmitted by the courts, including trial courts as well as appellate courts, and including informal mediation and private bargaining as well as adjudication. The product of the court is not doctrine with a mix of impurities, but instead a whole set of messages that can be used as resources in making (or contesting) claims, bargaining (or refusing to bargain) and regulating (or resisting regulation).

Such impact research would make it possible for courts to educate themselves about the consequences of their patterns - of discovery, settlement, cost, remedies, as well as their doctrinal production. What are the general effects of court routines as well as the occasional dramatic ruling? Such findings would provide the cognitive underpinning for a deeper, more responsible consequentialism in which courts were supplied with some capacity for systematic monitoring of their effects. ${ }^{83}$ Presumably, there is some point beyond which such self-regarding would be debilitating to courts,

81 See note 20 supra.

82 This literature is usefully surveyed in S. Wasby, The Impact of the United States Supreme Court: Some Perspectives (Homewood, Ill., The Dorsey Press, 1970). On the limitations of this genre, see Feeley, supra note 9, at 498 et seq.

83 A fascinating example of an attempt at such self-education is found in Renfrew, The Paper Label Sentences: An Evaluation, 86 YALE LAw Journal 590-618 (1977). A federal judge, attuned to the primacy of maximizing communication of antitrust norms to other businessmen, sentenced antitrust violators to a regimen of giving speeches about their offenses to audiences of their peers. The judge then conducted a survey to gauge the effects.

Of course, such judicial messages are only part of the whole complex of messages radiating from official (and other) sources, and the context may impart to a judicial message a meaning different from that it appears to carry when considered in isolation. See McCormick's argument that token enforcement and non-stigmatizing sanctioning of antitrust violations have neutralized public reaction against these violations and thus helped legitimate "prohibited" business practices. McCormick, Rule Enforcement and Moral Indignation: Some Observations on the Effects of Criminal Antitrust Convictions upon Societal Reaction Processes, 25 Social Problems 30-39 (1977). 
but I know no reason to believe that that point has been approached.

Of course, the centrifugal perspective also suggests that if we are interested in courts as sources of messages about entitlements and vindication, then we have to consider changes not only in the messages transmitted, but also in the basic structures for transmission e.g., the separation of appellate from trial courts. The agenda for reform might include experimental alteration of court structures or of transmission practices (e.g., televising court proceedings).

While awaiting the results of research and experimentation, the centrifugal perspective can yield some cautions. For example, it suggests that the money cost of particular kinds of litigation is an insufficient guide for policy, since it tells us little about the benefits produced by that litigation. These might include not only benefits to the winning party (compensation, vindication, etc.), but to the loser (his "day in court"), to others who might have been victimized by the loser (through incapacitation, rehabilitation, special deterrence), to a whole range of effects on wider audiences (general deterrence, moral validation, channelling, habituation, etc.). Again, the centrifugal perspective suggests that in deciding how the existing supply of courts should be allocated, the distinctive competences of courts as institutions offer only a partial guide. If most of the court's effects are remote and indirect, it is entirely possible that courts may confer more social benefits when doing what they do less ably than when doing what they do best.

\section{Conclusion}

Through the wrong end of the telescope, access to justice is not the movement of disputes into official forums, but the movement of bargaining and regulatory endowments from these forums into a world unevenly occupied by indigenous regulation. Schools play an important role in the generation, transmission and dissemination of knowledge, but they are not the exclusive or chief location of it. Just as we judge schools by their ability to equip us to learn in other settings, should we not prize courts for their success in equipping us to achieve justice outside their walls? If the performance of differentiated official institutions of justice is to be evaluated by their effects on indigenous justice, access to justice inquiry must be concerned 
with these effects. Although our knowledge is fragmentary and our concepts rudimentary, we know enough to conclude that these effects are neither trivial nor obvious and that they are importantly mediated by the capabilities of the disputants and the relations between them.

In interaction with these external factors, court processes may have inadvertent but important distributive effects. For example, standards for decision that involve individualized balancing of competing considerations may confer unintended advantage on disputants who are less risk averse. Since "risk aversion increases as the proportion of the [disputant's] wealth or income at stake increases," 84 the larger disputant will often be less risk averse and able to command the bargaining advantage derived from the uncertainty of the outcome. A commitment to access to justice then would imply inquiry into the possibility of arranging to prevent or offset unacceptable premiums and discounts that accompany the distribution of endowments by courts. How far are courts (or legislatures) capable of such systematic and calibrated fine-tuning of their "endowment-making"?

The influences that emanate from courts mingle with those from other sources. To move toward responsible optimization of these effects is more than a matter of applying existing knowledge. The commitment to enlarge access to justice entails a commitment to embark on research that will illuminate the relations between official forums and indigenous law. Research cannot answer the intractable questions of doing justice, but without it we are less likely to identify the real problems and the real choices that confront us.

84 Phillipps \& Hawkins, Some Economic Aspects of the Settlement Process: A Study of Personal Injury Claims, 39 MODERN LAw Review 497-515, at 504 (1976). 
THE JUSTICE SYSTEM OF THE FUTURE:

\author{
FOUR SCENARIOS \\ FOR THE TWENTY-FIRST CENTURY
}

by

EARL JOHNSON, JR.

Professor of Law, University of Southern California

During the past two or three decades, an old hobby of mankind - fortune telling - has become formalized as a field of scientific (or at least quasi-scientific) inquiry. Usually called "futurology" or "futures research," it attempts to forecast the future (or more usually a series of alternative "futures"). The term tends to be applied as much to prescription as prediction, at times resembling utopianism more than forecasted reality.

Without claiming to be a "futurologist" and without employing Delphic techniques or the other typical methodology of futures research, I intend in this paper to peer a bit into the future - not the immediate future, but that vague apparition looming closer and closer, the twenty-first century. To borrow some terminology from futurology, I will be presenting four alternative "scenarios" for the justice system of the twenty-first century. To be honest, they will be more like sketches of the future than complete scenarios. In attempting to identify what appear to be the four most likely scenarios, I will be treading a bit upon the subject matter of the first two sessions of the Florence Access-to-Justice Colloquium. But I will seek to keep that overlap to a minimum.

For convenience sake, I label these four alternative scenarios as 1) the "perfected formal judiciary" scenario, 2) the "maximum feasible deformalization" scenario, 3) the "systems analysis" scenario, and 4) the "lowered expectations" (otherwise known as the "return to the Middle Ages") scenario. These scenarios represent possibilities more than predictions. The real future may well partake of all four, but I suspect it will tend to drift more toward one or the other of these pure types. 
These scenarios all relate to the United States. I would not pretend to know enough to forecast even a hypothetical future for some other country. But to the extent they are at all realistic for America, I suspect the scenarios may be of some interest to other industrial democracies, as well.

For the most part, I have not attempted to reproduce the total society of the twenty-first century, only the justice system. Thus, I have assumed the profile of problems to be processed by the justice system will remain relatively stable. In reality, technological or sociopolitical change might drastically change the justice system's work. For instance, if sophisticated networks of absolutely safe mass transit entirely replaced the private automobile, personal injury litigation might be a less significant source of business for the courts. Or if hereditary transmission of property were abolished (with perhaps all private property escheating to the state upon death), probate would no longer be a relevant activity for the justice system.

As to the justice system itself, I have assumed some technological advances. On the other hand, I have been as unimaginative as possible in this area. For the most part, I only anticipate the widespread use of technology that already exists and its adaptation for use in the justice system.

Finally, I want to emphasize that I am not endorsing any one of these four scenarios as my personal choice. One of the advantages of futurology, at least the brand of futurology I have chosen to use, is that you can throw out ideas and predictions and possibilities without having to justify every word as being constitutional, legal or even wise. These scenarios accomplish my purpose if they stimulate thought and speculation among the participants in this conference.

With these qualifications and caveats in mind, we now leap forward to sometime in the twenty-first century.

\section{The First Scenario: The Perfected Formal Judiciary}

After experimenting with neighborhood justice centers, mediation, arbitration, and a host of other alternatives to the judiciary during the last two decades of the twentieth century, America rather suddenly shifted back to the judiciary as its primary (and virtually sole) dispute-resolving institution. Now in the year 20?? we have 
reached the culmination of these efforts - a perfected formal judicial model.

The key ingredients of this scenario are a nationalized legal service available to all citizens free of charge, a unified national court system, technologically sophisticated procedures, and a system of economic incentives encouraging negotiated settlements.

\section{A. Nationalized Legal Service}

A national legal service was assembled during the late twentieth and early twenty-first centuries, gradually accumulating the responsibilities formerly undertaken in a less comprehensive and coordinated way by the Legal Services Corporation, group and pre-paid legal services plans, and public interest law firms. It is funded entirely by the government and its services are offered free to any citizen regardless of his or her income level (with the exception of certain economic settlement incentives to be described subsequently). All other expenses of investigating and presenting a case likewise are free to the litigant (with the same proviso about settlement incentives).

Some lawyers work for the national legal service on a salary; others are paid by the government on a fee-for-service basis. But only lawyers employed on some basis by the national legal service are allowed to represent people or organizations in litigation. Moreover, they are not permitted to accept additional compensation from private litigants for this work. Other law firms still exist and are paid by corporations and wealthy individuals to give legal advice and other non-litigation services. But litigation advocacy is a monopoly of the national legal service and is entirely government funded. Moreover, although litigants are allowed freedom of choice among attorneys, all attorneys paid by national legal service funds are subject to assignment and cannot be reserved on a permanent basis for any litigant, no matter how wealthy or powerful. Beyond that, as a general rule the same lawyer cannot represent a given litigant in more than one case during any five-year period.

All of these limitations are designed to insure parity between litigants, which is the whole basis of the perfected formal judiciary scenario. Lawyers on the national legal service panel are differentiated by skill and experience as well as expertise. Thus, the better 
lawyers are reserved for the more complex and significant cases. But in a dispute between General Motors and John Q. Public, the individual has just as good a chance of having the better attorney as does the huge corporation.

A legal historian has made the astute observation that there is some analogy between the barrister-solicitor distinction that existed for so long in England and the national legal service lawyer (who is allowed to go to court) and the remainder of the legal profession (who essentially provide legal advice). There are real differences, of course. A private party could always retain a barrister if involved in litigation, while in twenty-first century America only those paid with government funds are allowed to undertake litigation. Moreover, the national legal service will pay for legal advice and other non-litigation-related legal assistance for lower and middle class individuals.

Only recently has the national legal service solved the major problem that has plagued it since its birth more than a decade ago independence from real or imagined political domination. Less than a year ago, the United States Constitution was amended to create a fourth branch of government, the so-called advocacy branch. This branch is headed by a Chief Advocate who stands on a par with the President, the Chief Justice, and the Speaker of the House. Although the advocacy branch has other responsibilities and divisions, including providing citizen representation before legislatures, over 80 percent of its funds and more than two-thirds of its personnel are involved in the national legal service.

The constitutional amendment that created the advocacy branch also provides a secure base of government funding not subject to legislative or executive interference. A 20 billion dollar trust fund (equivalent to two billion in 1979 dollars) was created. The Constitution mandates that Congress appropriate sufficient funds each year to maintain that trust fund (out of which the advocacy branch pays its operating expenses) at the 10 billion dollar level. This is not a discretionary item in the government's annual budget. Congress must appropriate the funds, and the President's signature is not required to authorize the appropriate transfer of funds from the U.S. Treasury to the advocacy branch. Consequently, no President can veto an appropriation for the advocacy branch, except to the extent that it exceeds the amount necessary to restore the trust fund to its constitutional minimum of 10 billion dollars.

Other clauses in this constitutional provision contain further 
guarantees. A constitutional right to free and independent counsel is created. And the Constitution further stipulates that no one, including the Chief Advocate, is allowed to interfere with the relationship between attorney and client or the independent judgment of the lawyer in advising or representing his client. In what some deem an oversensitivity to possible infractions of these provisions, the constitutional amendment creates a special investigation-prosecutorial body to look into any claims of abuse lodged by people the advocacy branch was asked to represent. By the terms of the constitutional provision, this body is not attached to the advocacy branch, but rather to the judicial branch of government. (It should be remembered that by this time in the twenty-first century, the United States has a national judiciary rather than two parallel federal and state systems. See sec. I.B infra. Thus, it is not extraordinary to have a staff affiliated with the judiciary investigating conduct that may occur at the local level.)

\section{B. Unified National Court System}

In the late twentieth century, the United States finally dissolved one of the major barriers to a perfected judicial system capable of handling all disputes. Without otherwise tinkering with the federal system, the 50 state court systems and the federal judiciary were merged into one. This unified court system applies both state and federal law, as appropriate, under precise, rather complex conflict of laws rules to any dispute filed with the courts.

There is nation-wide jurisdiction for any dispute, including a national small claims court. If someone in California buys a defective microwave oven manufactured in New Jersey and sold by a mail-order house in Chicago, there is no question about whether the court in California has jurisdiction over the Chicago seller or the New Jersey manufacturer. The whole country is considered one jurisdiction, and the California courts are considered part of the courts of that single jurisdiction with power over anyone or any institution located anywhere or anyone doing business anywhere in the United States.

Because the courts of the twenty-first century have accepted the technological breakthroughs of the twentieth and twenty-first centuries (see sec. I.C infra), disputes can be resolved between people 
from various parts of the country at minimal expense and without any significant travel or inconvenience.

The United States Supreme Court, of course, remains the court of ultimate jurisdiction for appeals. Immediately beneath the Supreme Court there are 10 Regional Courts of Appeal that hear appeals from state appellate courts. (These ten regions coincide roughly with the multi-state circuits that formerly were served by the U.S. Circuit Courts Of Appeal before they were supplanted by these regional courts.) Depending upon the size of the state, there may be one or two tiers of appellate courts above the trial courts and the small claims courts. But they all feed into the Regional Courts Of Appeal and the United States Supreme Court.

All judges of the national court system are employees of the judicial branch of the federal government. However, those serving on the trial bench and the intermediate court of appeal, if any, are selected by state government. The State Supreme Courts, on the other hand, as well as the Regional Courts of Appeal and the U.S. Supreme Court are picked by the President with the advice and consent of the Senate, subject only to the limitation that those serving on State Supreme Courts must be selected from citizens of that State.

\section{Tecbnologically Advanced Proceedings}

Concentrating all disputes great and small, simple and complex, in a unified formal judiciary would have been difficult, if not impossible, using the procedures and technology typical of the courts of the 1970's and 1980's. By the twenty-first century, however, when the decision had been made to move toward this solution, there was ready acceptance of the many scientific advances then available to conduct a judicial proceeding.

Extensive travel by any of the participants has been virtually eliminated. Someone with a grievance need not go to the courthouse or a lawyer's office. He or she merely walks to the nearest multi-purpose, multi-media neighborhood communications center and asks to be connected with the national legal service. The disputant is quickly linked by television and computer with a paralegal interviewer who obtains the basic information, ascertains the general nature of the dispute and quickly passes on the dis- 
putant to the appropriate lawyer. After some preliminary investigation, the disputant's lawyer makes television contact with the prospective defendant, and a lawyer quickly is arranged for that person or institution whether the defendant is a neighbor in the same apartment building or a gigantic corporation headquartered 3,000 miles away.

If the two lawyers and their clients are unable to work out an appropriate compromise through their conversations by television and sometimes computer, a case usually will be filed with the court. Unlike the antiquated procedures of the twentieth century, however, a case is not initiated by a written pleading. Rather, the computer in the lawyer's office "talks" simultaneously to the court's main computer and the defense counsel's computer, spelling out the nature of the claim and the relief requested. Thereafter, all motions and other communications with the court are entered by computer.

Most oral testimony is taken by televised depositions held at or close to the deponent's home, with counsel for both sides remaining in their offices asking questions and making objections again solely through two-way television. At the trial itself, videotapes of these depositions are presented to the judge. If it is a jury trial, the jurors view the case and conduct their deliberations from their homes (if they have the requisite equipment) or at the nearest neighborhood multi-purpose, multi-media communications center, if they do not.

This twenty-first century communications and computer technology means that disputants located thousands of miles apart can resolve a major or rather minor controversy without leaving their homes or, in the worst situation, without leaving their own neighborhood. Furthermore, jurors can be drawn not just from one community or the other but from both and, if deemed desirable, from neutral territory located hundreds or thousands of miles from either disputant. Neither witnesses, lawyers, jurors nor anybody else need travel great distances to congregate at a single location for an indefinite period of time in order to conduct a trial.

Recent twenty-first century innovations that have become part of the process rely heavily on computer technology. Pleadings, documentary evidence and depositions are fed into the computer prior to the trial. This computer called "JUSTIN" is programmed to analyze all of this inserted data to isolate issues about which there seems to be no real controversy from those that seem in doubt on the basis of the information presented by the two parties. "JUSTIN" 
further advises the judge and/or jury about the legal implications of the undisputed issues and those still in question. Thus, the human fact-finders need only concentrate on a very few factual issues truly contested by the parties rather than waiting to hear whether some essential but undisputed fact actually will be established by the evidence. It is estimated that "JUSTIN" cuts trial time to less than 20 percent of the twentieth century average.

\section{Economic Settlement Incentives}

One consideration delayed the shift to a "perfected formal judiciary" approach for several years. Opponents of the idea argued that if dispute resolution were made costless for both parties in every dispute, nearly all cases, including the insignificant ones, would be dragged through the entire process at great cost to the government. Each side to a dispute would know that it could file any motion, take any deposition, appeal any verdict or take any other litigation step without any cost. Furthermore, the lawyers themselves would know that their salaries or fees would be paid by the government no matter how insignificant the dispute or how marginal the litigation step they contemplated. The constraints that inhibited even wealthy individuals from filing lawsuits in modest disputes or had slowed their investments in substantial lawsuits would no longer be present when the government absorbed all costs of litigation.

Proponents of this approach ultimately prevailed. But they did so only by creating a comprehensive system of economic incentives calculated to induce parties and their attorneys to settle disputes early and equitably. The result is a rather complicated game of economic penalties and rewards which requires a careful balancing of probabilities, outcomes and uncertainties. In essence, only lawyers possess the knowledge and experience to make the tricky calculations. But since all litigants are represented by lawyers at government expense, this is no particular problem.

This settlement incentive system actually comes into operation even before someone has filed suit. A prospective plaintiff is required to submit an intent to file lawsuit accompanied by a confidential statement as to what he or she would be willing to accept from the defendant. The defendant is then contacted and requested to forward a confidential statement as to what he or she would be 
willing to offer the plaintiff, if anything. If these offers should happen to coincide or overlap, the court declares a settlement and gives a substantial cash reward to both parties. Once the lawsuit is filed, the parties are committed to a mandatory sequence of confidential settlement offers. They must submit these proposed compromises to the court in sealed envelopes at various stages of the proceedings. Once again, if the court upon examining these offers determines that they coincide or overlap, a settlement is declared, and both parties receive some cash reward. The earlier the settlement is achieved, the larger the reward.

Should the case proceed to trial, however, the economic incentives shift from reward to penalty. The ultimate judgment is used as a benchmark, and previous settlement offers submitted by each party are judged against this standard. Penalties are assessed against one or both parties depending upon the reasonableness of prior offers, judged both by how much the offers deviated from the ultimate judgment and when those offers were made. Thus, offers that deviated more from the judgment would be assessed higher penalties. And even relatively minor deviations, if they only came shortly before the case was tried, would result in significant sanctions.

It should be emphasized, however, that all economic penalties are scaled to the relative economic resources of the parties. Accordingly, someone of relatively modest income might be penalized only a fraction of what a more affluent individual or business enterprise would receive for an absolutely identical discrepency between offers and ultimate judgment. As a result, the pressures on the litigants are equalized. The well-to-do face a much higher schedule of penalties for unreasonable conduct during settlement negotiations; the low and middle income litigants, lesser sanctions carefully scaled to produce similar pressures to negotiate in a reasonable manner.

In a recent innovation just introduced two years ago, a similar system of rewards and penalties operates to influence the lawyers themselves. Lawyers whose clients make offers that result in settlements receive modest bonuses applied to their salaries or fees. Those whose clients engage in unreasonable conduct during the course of the lawsuit are assessed minor penalties, though once again scaled to the amount these offers deviate from the ultimate outcome and the point in time that they are made. In order to minimize conflict between attorney and client, these rewards and penalties are maintained at a minimal level. Over the course of a year, they would 
amount to only a fraction of the staff lawyer's salary or the fees likely to be received by a private advocate out of the national legal service fund. The amounts are calculated to be just enough to provide some inducement for lawyers to advise reasonable settlement terms by their clients but not enough to allow attorneys to add significantly to their income by counselling early and disadvantageous offers (disadvantageous to that particular client, that is) merely to line the lawyers' pockets.

It should be noted that this system of economic incentives applies to non-economic disputes, as well as to the personal injury cases, contract actions, etc., essentially involving only monetary values. By the twenty-first century, multi-attribute utility analysis and related techniques have reached a high level of sophistication. Divorce, custody, and other essentially emotional disputes have been converted to economic schedules. First, the various potential outcomes of such disputes were converted to different quantities of "utiles." Then these "utiles" were translated into dollar equivalents. Through this technique, offers of various terms in such disputes can be compared and used as the basis of assigning rewards or imposing penalties on the litigants making those offers.

Whether attributable to the system of economic sanctions or not, settlement ratios are extraordinarily high. Over 99 percent of disputes are compromised prior to filing in court, and over 99 percent of those filed in court are settled before trial with the vast majority concluding before any court action whatsoever. A "big" case is as likely to settle early on reasonable terms as a "minor" dispute. The high ratio of settlement both before and after a lawsuit is filed is a testament primarily to the expertise of lawyers in predicting the probable outcome of disputes when they are not influenced by their own economic advantage (except in the direction of making correct estimates). Some measure of the credit also must go, of course, to the more sophisticated transmission of information about appellate decisions, jury verdicts, etc., through the computerized communications networks of the twenty-first century.

Perhaps more significantly, social science research has established that the terms of settlements achieved before or after the filing of lawsuits are much more equitable than those prevailing in the twentieth century. The scaling of penalties to making the economic incentives proportional to disputants' economic resources has resulted in nearly equal settlement pressures on both sides of each dispute. 
Thus, in the overwhelming majority of cases the settlement terms closely approximate what a judge or jury would have decided had the case gone through the entire process.

\section{E. What People Are Saying About the Perfected Formal Judiciary in the Twenty-First Century}

Because the twenty-first century judicial system is free to litigants and relatively speedy and precise, most private dispute resolution forums have withered away. Commercial and labor arbitration, for instance, no longer exist. Even though most U.S. jurisdictions have adopted no-fault automobile insurance, disputes that arise between injured policy holders and their first party insurance companies are taken to the court rather than to some arbitration plan.

Supporters contend that the availability of a free judicial forum applying precise legal rules in completely fair proceedings between equally equipped adversaries has had several desirable effects.

First, people have fewer grievances because people and institutions behave better, especially business enterprises. "They know they can't get away with overcharging or shoddy merchandise," one consumer advocate claims, "because if they do something like that, their customers will have them in court the next day."

Secondly, the courts only have to decide a tiny fraction of the disputes that do occur. Since both parties have free access to equally skilled counsel, most cases settle and settle early. The balanced economic incentives also contribute mightily to this result. The lawyers are experienced at predicting probable outcomes and are strongly motivated to make early and realistic settlement offers. Since the process is costless to litigants (unless they behave unreasonably in settlement negotiations) and trials occur within a few weeks of filing, economically powerful litigants cannot hope to "wait out" their adversaries. So they have just as much incentive to settle early and fairly as the poor or middle class individual.

Thirdly, supporters contend the system actually is less costly to the taxpayer than the old twentieth century judicial system with its dependence on "private enterprise" legal representation. "We'd have a lot more grievances, a lot more disputes, and a lot more cases going to trial if we still had that antiquated system," one Senator observes. "So even though the public sector would only be picking up 
maybe a third or a fourth of the cost, the total bill would be higher. We're resolving cases for less than $\$ 1,000$ a piece $(\$ 100$ in 1979 dollars) on the average. That's because over three-quarters settle during the first teleconference between the two lawyers and their disputants, and most of the rest just a little bit later. And don't forget what it meant to rely so much on 'free enterprise' lawyers in the twentieth century. Lots of people couldn't afford them, so they were helpless in litigation. And most of the really good courtroom lawyers worked for big businesses or rich people, so the average guy didn't have a chance even if he could hire some mediocre attorney. Many of the out-of-court settlements were really capitulations by some citizen who was simply bewildered and outmaneuvered and overwhelmed. Let us not forget. Thiose kinds of costs have to be factored in when we're comparing our twenty-first century system with what went before."

But the perfected formal judiciary is not without its critics in the twenty-first century. Some point to the heavy public investment. Others are concerned that government is forcing all disputes through a single mode of dispute resolution. "Sure, lawyers and judges and the adversary approach work pretty well for some things, contract disputes for example," a leading psychologist argues. "But what about child custody or even divorce? These are emotion-charged issues involving long-term relations between people who have to continue living together or at least relating to each other for years in the future, maybe a lifetime. Lawyers and legal rules may have a place, sometimes, but it's not even the primary one, to say nothing of the exclusive monopoly role they've been assigned under our current system. People are ending up having settled the less important 'legal' issues and haven't begun to touch the real problems. So what dispute has been resolved? None."

Other critics zero in on the government's monopoly control over the dispute resolution function. Some lawyers, generally older ones educated in the twentieth century, warn: "Just remember, you have to be on the government pay-roll - at least be getting your fees from the government - to be allowed to represent anyone in court. That may be OK for now, with the governments we've been having in the twenty-first century. But what about the twenty-second? It would be awfully easy for some President who had good support in Congress to gang up and make sure only the right kind of lawyers and the right kind of cases were allowed in court. And he would do it in 
spite of that new-fangled constitutional amendment, I betcha. Why, remember back in ' 80 when that old guy - what was his name almost got elected. He made no bones he'd have cut off that primitive legal services program they had for poor people in those days. What if a guy like that got himself elected in the twenty-second century? Or maybe even the twenty-first, you can't be sure? What do you think he'd do to this 'perfected formal judiciary' of ours?"

Community activists disapprove of the perfected formal judiciary for still another set of reasons. "It's monolithic. It's sterile. It's overprofessionalized. And it puts too much power in the hands of government bureaucracy. Disputes involve people. Dispute resolution belongs to the people! We need a pluralistic approach. Different forums. Different groups in charge. Different ways of resolving disputes. More humanity and more humanism in the whole set up. Let a thousand flowers bloom."

\section{The Second Scenario: Maximum Feasible Deformaliza- tion of the Justice System}

The 1970's and early 1980's experienced an escalating series of crises in the courts and an ever rising clamor of dissatisfaction with the overall performance of these traditional forums. Ultimately, this led to an unprecedented era of drastic experimentation and revolutionary reform. What has emerged in year 20?? is a very different justice system relying primarily on forums and personnel very different from the twentieth century version.

The key principles underlying this revamped system are deprofessionalization, community involvement, minimum necessary coercion, and pluralism. These goals are implemented through three core elements: 1) a network of "neighborhood justice centers," 2) a panoply of specialized forums for different categories of disputes, and 3) technological support for these forums.

\section{A. Neighborhood Justice Centers}

The "neighborhood justice centers" are vastly more powerful and sophisticated versions of the pilot centers first established in the United States during the late 1970's. Because of the complex array of

14. 
specialized forums that have taken over most of the work formerly handled by courts, the neighborhood centers are especially important for the average citizen. Personnel at these offices screen all disputes and match them to the correct forum.

Critical as it may be, however, this screening function is not the only purpose for these neighborhood justice centers. For most disputes between people or institutions in that neighborhood, the center is the last stop as well as the first. Unlike the primitive 1970's version, the centers possess arbitration and even adjudicative powers as well as offering voluntary mediation. ("Neighborhood tribunals," as well as local "minor disputes tribunals" and "marketplace tribunals," described infra, all operate out of the "neighborhood justice centers.")

\section{B. Specialized Forums}

The specialized forums exist at several levels - neighborhood, metropolitan, state and even national. Lawyers and other professional advocates are barred from many. Detailed legal norms apply in only a few, although they set the outside parameters in most. And in many forums, common citizens carry out the primary dispute resolution tasks.

Divorces (now called marriage terminations) and most other intrafamily disputes are processed through "family relations bureaus." Though similar in function to the family courts prevalent in some states during the twentieth century, these bureaus are staffed by "human relations specialists" (similar to the psychologists and social workers of the twentieth century but with a broader range of skills and education). Instead of adversary presentations before a judge in a formal court setting, they employ a variety of non-coercive techniques - mediation, individual and group counseling and the like. The goal is to work out a long-term future relationship with respect to economic issues and custody arrangements that will be most conducive to the happiness and emotional health of all parties father, mother, children, husbands, wives, etc.

On the rare occasions that it proves impossible to achieve agreement between the parties, the family relations bureau is empowered to impose a resolution, for instance, to grant a marriage termination and specify the custody terms, property division, etc. However, even 
these unusual cases are decided by panels of human relations specialists rather than judges or juries. The only limitation is that the terms of all resolutions of family disputes, whether the product of mutual agreement or imposed decision, must fall within the broadly drawn parameters of a statutory schedule. For instance, this law sets maximum and minimum levels of child support for different incomes and circumstances. A family relations bureau cannot authorize payments above the maximum nor below the minimum.

It should be noted that in twenty-first century America, most child custody and financial support issues have been rendered moot. With rare exception, both parents are employed ( 25 hours a week on the average), and from the age of six weeks children spend their days in government-funded child care centers. Women and men earn equal incomes (on the average), and neither is required to serve a custodial role that interferes with employment. Thus, in the typical situation, they alternate custody in their off-duty hours, and neither pays child support or alimony. On the other hand, property division remains a significant issue as do the details of child custody arrangements.

Disputes about defective products, poor service and other consumer problems are dealt with through "marketplace tribunals." These actually are a complex network of local, regional and national tribunals, specialized by product or service and the source of the alleged problem. If the quarrel is between a consumer and his neighborhood drycleaner about how it mishandled his garment, the dispute is assigned to the local "Drycleaning Market Tribunal." But if his complaint was that the garment was ruined because of a defect in the drycleaning fluid supplied to the cleaning establishment, it might be referred to a regional or national Drycleaning Market Tribunal.

At whatever level the consumer's grievance is considered, the process is similar. The tribunal staff attempts to mediate the dispute, often connecting the consumer and merchant by television in a three way conversation. If that attempt is unsuccessful, an investigative staff searches out the facts, again placing great reliance on the advanced telecommunications and scientific facilities of the twenty-first century. Further mediation attempts may be made as the investigation clarifies the situation. Disputed cases ultimately are submitted to the relevant market tribunal. These tribunals are composed of representatives of consumer and producer interests with a "neutral" 
chair. Tribunal size depends upon whether it is a local, regional or national tribunal. Local tribunals consist of only three members, regional of five, and the national of seven to eleven depending on the industry.

The tribunals rely heavily on investigative reports submitted by the staff. Nonetheless, on occasion they hold "oral" hearings through a telecommunications hookup with the parties.

The "marketplace tribunals" are not bound by firmly established legal rules. Their guide is fairness in the individual case and adherence to reasonable standards of safety and performance by the seller/producer. They have access through twenty-first century telecommunications facilities to technical information about reasonable standards and the quality experience of that particular seller/producer compared to others in the same geographic area or field of endeavor.

The tribunals have adjudicative power to compel appropriate relief for the consumer. But beyond that, regional and national tribunals are empowered to publicize aggravated or widespread abuses they discover in the practice of a given merchant or manufacturer. Local tribunals can only forward their experiences to higher tribunals for review and possible publication.

This power to publicize patterns of defects or abuse tends to encourage early settlement of most grievances and preventive action by sellers to reduce the quantity of complaints. (The advanced telecommunication and information facilities of the twenty-first century facilitate this role. Merely by punching the appropriate buttons on his home or neighborhood two-way television/computer, a customer can obtain detailed information about the performance and complaint history of a given product, service or merchant.) Research early in the development of the "marketplace tribunals" demonstrated that their rather expensive process was more than justified by improvements in the quality of goods and services sold in the market place. In any event, the cost of these tribunals is defrayed by a tiny "consumer justice" tax which is added to all merchandise sales of over $\$ 1,000$ (\$100 in 1979 dollars).

While "marketplace tribunals" handle most controversies between consumers and sellers or producers, another specialized forum takes care of disputes between the business enterprises themselves. Called "commercial tribunals," such forums exist at the local, re- 
gional and national level. They, too, are divided by industry as well as geography. "Commercial tribunals" are composed of management level employees knowledgeable about the technology and business customs of the industry in which the dispute arises. Except for a few industries, each panel member serves only occasionally. They are selected for particular disputes by a computer programmed with detailed information about their backgrounds.

These commercial tribunals differ in important respects from the other specialized forums of the twenty-first century. First, lawyers play an important role investigating and presenting the cases heard by these tribunals. The cases tend to be complex and frequently involve hundreds of thousands or millions of dollars. The proceedings are conducted in a rather adversary manner, although not so adversary as twentieth century courts.

Commercial tribunals are financed in a manner analogous to the "marketplace tribunals." Rather than draw on general revenues or fees assessed disputants when they bring a case to the forum, the costs are imposed directly on the activity which inevitably generates a certain quantity of disputes, in this case, commercial contracts and arrangements. Consequently, a small "commercial justice" tax is imposed on every commercial agreement, scaled to the value of that agreement.

Landlord-tenant disputes are assigned to "housing boards." These forums function essentially in the same manner as the "marketplace tribunals." In this case, however, the decision-making bodies are composed of equal numbers of tenants and landlords and are chaired by homeowners who do not own rental property. But once again the key role is played by the non-lawyer staff that attempts early mediation, investigates the facts of the dispute, and, where necessary, presents a written report to the decision-making body.

Essentially emotional disputes between members of the local community - of the barking dog and irritating children variety - are handled by "neighborhood tribunals." These are composed of residents who have volunteered to participate on a panel up to four times a year. A different panel is chosen for each dispute by a computer which picks members likely to be perceived as unbiased by both parties. "Neighborhood tribunals" cannot compel compliance with their decisions. Instead, these tribunals rely upon moral suasion and the fact that their recommended resolutions are published. 
Either disputant can request that a "neighborhood tribunal" be convened, and the other disputant can be compelled to at least attend the mediation session. In making their own recommendations in cases where their mediation efforts have failed, these "neighborhood tribunals" apply their own subjective notions of fairness and equity. Thus, they are in no way bound by statutes, court precedents or other substantive legal rules. The goal is to decide such disputes by the community norms of people residing in that particular geographic area.

All remaining small and modest claims actions, that is, essentially economic disputes which do not fall within any of the categories handled by the specialized tribunals mentioned above, are dealt with through "minor disputes tribunals." As is true of most disputes, the action starts when the grievant goes to a neighborhood justice center. If the center determines that this is a dispute appropriate to a "minor disputes tribunal," it assigns the case to either a local or metropolitan "minor disputes tribunal" depending on who is involved in the dispute. If a resident of the area served by the neighborhood justice center lodges a grievance against another resident of that area, then the case is assigned to a local "minor disputes tribunal." But if the dispute involves someone from outside that area then the case is referred to a metropolitan "minor disputes tribunal." It should be highlighted, however, that a referral does not mean that the grievant must physically take his case to another office far removed from his neighborhood. A neighborhood justice center is empowered to accept a case from anyone, even a tourist passing through town. A nationwide computer hookup links all neighborhood justice centers to all types of specialized tribunals, local, regional and national, as well as to all other neighborhood justice centers. This same computer network also connects with the regular court system.

The "minor disputes tribunals" are composed of three private citizens chosen by computer from a comprehensive list of all American citizens. The computer is capable of drawing a panel from a neighborhood or other small geographic area or from an entire county or metropolitan area. These "minor disputes tribunals" differ from the "neighborhood tribunals" mentioned above in several ways. First, a different panel is not composed for each dispute. Rather, a given minor disputes panel will sit for an entire evening and hear all the cases they can in that sitting. Furthermore, these 
"minor disputes panels" have adjudicative power. In a sense, they are like small juries, except they decide cases without the presence of a judge, acting as interpreters of what "rules" or criteria should govern the disposition of a dispute as well as performing the traditional jury role of judging the facts.

The technological advances of the twenty-first century, however, make it possible for these "minor disputes tribunals" to take account of specific statutes and other legal rules as well as their own notions of fair play in making their decisions. A two-way computer terminal in each hearing room "listens" to every case as it is heard by the tribunal. This terminal performs two important functions. Merely by pressing a request button, the panel can obtain a printout of any substantive law applicable to the set of facts presented by this particular case. (It should be highlighted that this printout is an upto-date "plain language" summary of the applicable rule. The technical terms of a statute, for instance, are translated into common words, and any court interpretations of ambiguous statutory language are incorporated directly into the summary.) A "minor disputes tribunal" is not bound to follow the legal rules the computer terminal presents, however. These rules are merely a suggested guide which can be modified or even discarded by the tribunal if deemed inconsistent with local community norms of fairness and equity.

An assortment of private and quasi-public mechanisms resolve several important categories of disputes not handled by the specialized tribunals outlined above. All U.S. jurisdictions now have comprehensive no-fault automobile insurance programs. All of these require that disputes between the insured and their first party insurance companies be submitted to private arbitration. State laws set forth minimum standards for arbitration, including how the panels are to be selected, various procedural elements, etc. Similarly, labor arbitration has expanded to encompass nearly every dispute arising between union members and management or unions and management. Workmen's compensation boards now handle all employmentrelated injuries in all states. All public and private institutions from prisons to hospitals and schools are required to have mediation and arbitration programs for their inmates, patients, etc. These programs must be available for grievances about the institution's administration as well as disputes between inmates, patients, etc. Moreover, these mediation and arbitration programs must comply with standards established by statute. 


\section{The Role of the Courts After Maximum Feasible Deformalization}

The courts have not withered away completely with the advent of this vast array of non-judicial forums, public and private. But their caseloads have diminished to a small fraction of twentieth century figures.

With that reduction in absolute numbers of cases to be processed, the role of the judiciary has been transformed. No longer the primary and most visible public dispute resolving bodies in American society, courts now are more explicitly and extensively involved in public policy formation. Their civil caseloads are dominated by class actions, "test cases," actions for injunctive relief, and the like. Litigants seldom come to the courts for resolution of personal grievances. Rather, they come there for one of two reason: first, to obtain wholesale relief for a large group of people or against a widespread pattern of conduct, or, second, to seek a permanent change in legal rules.

The emphasis on using the courts for public policy cases in the twenty-first century has had several predictable results. The composition of the caseload has changed as much as the total number of disputes processed. These class actions, test cases, injunction cases, etc., are much more complex on the average than the fender benders, uncontested divorces, etc., that tended to dominate the individual statistics of the twentieth century. Thus, although caseloads have shrunk to less than five percent of twentieth century levels, the judiciary still remains at over 50 percent its former staffing. And those judges still complain legitimately about overwork. "But at least it's all interesting work nowadays," one elderly judge reminds his fellows. "Why, I remember back in the eighties when I first started on the bench. They made me sit in divorce court for five years, doing nothing but listen to wives get up on the stand and tell how their husbands deserted them or beat them or something. Most of it was damned lies. Damned boring lies. Now we've got cases we can sink our teeth into. May only work five or ten cases a year. But they're important cases, interesting cases, damn interesting cases. Why I remember back in $1985 \ldots$ or was it $1984 \ldots$ or...." 


\section{Critics of Maximum Feasible Deformalization}

Not everyone is so pleased about the maximum feasible deformalization of the justice system. For some, the movement has not gone far enough. "Most of these tribunals and centers are still organs of the government," one community activist objects. "We want "the people' to control dispute resolution in this country. These forums should be torn free from government and given to community groups to operate."

Other twenty-first century critics argue the new system that has evolved is simply too expensive. "Every grievance requires a hearing now," a fiscally conservative political leader argues. "It used to be that most cases settled because it cost so much to litigate. And besides, people could predict what would happen if they went to court. Or at least their lawyers could. The law was pretty well fixed and pretty well known. Now you go to one of these tribunals and who knows how it'll turn out. No legal rules, just 'fairness and equity.' Now who can predict what some bunch of citizens will figure is 'fair and equitable.' And it doesn't cost anyone a thing to go to one of these places, so they go and go and go. And we have hearing after hearing. And you know who pays? The taxpayer, that's who. And he pays and pays and pays. I bet if we went back to a regular court system, we'd cut our justice system budget in half or maybe to one third or one fifth of what we're paying to maintain all these amateur tribunals. Why, I remember back in '98, when we...."

\section{The Third Scenario: The Systems Analysis Approach}

Confronting a court system verging on collapse, the leaders of the judiciary turned in the late twentieth and early twenty-first centuries to systems analysis and operations research for answers to their several dilemmas. Out of this evolved a dramatically revamped system of resolving disputes - with the emphasis on "system." By the year 20??, fewer disputes are being handled by a greater variety of institutions and processes. Each institution and process is especially tailored for the type of dispute it handles. 


\section{A. The Systems Analysis Approach to the Traditional Functions of the Courts}

Perhaps the primary result of this systems analysis approach is that major categories of cases that dominated the civil caseloads of the courts through most of the twentieth century no longer are processed though the courts. In fact, in most instances, these matters are no longer handled as disputes at all by any dispute resolving institution. As a general rule, for example, issues of compensation for economic loss - whether as a result of accidental injury, a failure to live up to a contract or otherwise - no longer are handled as disputes. Similarly, uncontested divorces and uncontested decedent's estates are no longer treated in an artificial manner as if they involved true disputes between the parties.

What the systems analysts did first was to determine what it is that the twentieth century courts did - that is, what functions they performed and which kinds of matters they handled. The systems analysts quickly ascertained that, for the most part, the disputes handled by the courts were not a natural phenomenon. Or at least that given what the courts did with those disputes, they were not fulfilling a true psychological need felt by the disputing parties. Moreover, the "law," sometimes created by the courts, sometimes by the legislatures (and sometimes both), tended not just to structure, but to create the dispute.

The functions of the courts, as conceived by the systems analysts of the twenty-first century were fourfold: 1) to provide economic compensation to someone arising from a previous incident, 2) to compel someone else to do something or to refrain from doing something in the future, 3 ) to alter one's legal status, generally in order to enable one to do something different in the future, or 4) to "resolve" a dispute between the parties in the sense of repairing their relationship. (The systems analysts were careful to indicate that these were the functions of the courts as far as the individuals bringing their disputes to these forums. They recognized that society often had a stake in the enforcement of certain policies and norms when the court disposed of these cases. They further explicitly highlighted that very few disputes, if any, involved all of these functions. In fact, in most cases filed with the courts, one or the other of these objectives dominated.) 
1. Economic Compensation through the Income Tax and Transfer Agency

Economic compensation for past incidents is now handled through the income tax/transfer system. This system is operated by the successor to the Internal Revenue Service (IRS) which is called ITTA - the Income Tax and Transfer Agency. ITTA was first established in the latter years of the twentieth century when a negative income tax program was enacted to supplant most forms of welfare assistance. This negative income tax applies to persons whose income falls below a level which approximates one-half the median. It provides income supplements (i.e., negative income tax) periodically to make up the difference between earnings and the minimum standard of one-half median income. (The payment schedule is somewhat more complex than this, because income supplements are scaled to family size and also adjusted to maintain work incentives.)

After extensive experimentation during the latter part of the twentieth century and the early years of the twenty-first, a loss compensation function was added to the ITTA's responsibilities. The Agency by this time had refined its process for making affirmative payments to American citizens as well as collecting taxes from them. It was relatively easy for ITTA to take account of another reason, other than poverty, for adjusting the income levels of individual Americans.

Initially, this loss compensation program only applied to accidental injuries to the person. It did not even cover property damage arising from accidents. But gradually other types of economic loss were added to the system. Now in the year 20??, citizens can claim virtually any loss no matter what its nature or cause so long as it has financial implications, including property damage caused by accident or criminal activity and even net economic losses attributable to uncorrectable breaches of contract. (As will be noted later, twenty-first century courts have much greater power to compel specific performance of contracts, and they exercise that authority very liberally. Hence, uncorrectable contract breaches tend to be limited to situations where it is impossible to perform.)

Whatever the cause of the loss, it is reported immediately to the ITTA, generally through the citizen's local neighborhood telecommunications center. Through its highly computerized information processing system, the Agency validates the claim and compares it 
with the data bank's up-to-date information about the citizen's income, deductions, and tax withholding. ITTA then adjusts the citizen's tax withholdings and transfer payment amounts to reflect the claimed financial loss. Thus, if the loss, when amortized over the full period it will be felt, is less than the tax that would be withheld from income during that period, the adjustment is reflected as a reduction in withholding tax (with a consequent increase in net income received by the claimant.) However, if the amortized loss exceeds the level of withholding tax, the net loss is paid out as a series of periodic checks to supplement any earned income during the relevant period. (Of course, withholding tax will be completely eliminated during that period, as well.)

This approach to compensation of economic loss is possible largely because of changes in the notion of what constitutes appropriate compensation, especially in the case of accidental injury to the person. The often huge and always unpredictable damage awards that used to be prevalent in most societies during the twentieth century have been replaced by a concept pioneered in New Zealand. An injured person is entitled only to out-of-pocket expenses and replacement of lost income with only modest set payments for loss of function and enjoyment. But these payments are granted without regard to what caused the accident or who was at fault.

In the twenty-first century, America has a comprehensive health insurance plan which also absorbs the costs of ambulances, necessary travel to and from the hospital, and home care for all sickness and injury. As a consequence, the out-of-pocket expenses associated with accidental injury tend to be rather minimal. Thus, with rare exception, these out-of-pocket expenses can await filing of the annual tax/transfer return.

Periodic deductions/payments generally consist of two parts in the case of accidental injury. First, there is the income replacement component for all injuries where someone who was an earner is unable to work for a period of time or must reduce his or her hours of work because of the injury. The second component is the deduction/payment for loss of function or enjoyment (what would have been called "pain and suffering" under the fault liability system). The amount of this payment is fixed by schedule. Someone who is blinded receives a certain periodic deduction or payment which is considerably more than that received by someone who lost a finger.

Most claims are honored without investigation. The entire system 
depends upon two factors: the essential honesty of most American citizens and spot-check audits of a more or less random sample of claims. Stiff civil and criminal penalties await any citizen who files an erroneous or fraudulent claim for compensation. Because of the advanced technology and extensive computer files existing in the twenty-first century, it is relatively easy for the ITTA to screen complaints and conduct a cursory validation prior to granting relief. This process, however, takes at most three or four days and does not appreciably delay receipt of an appropriate deduction or payment by the plaintiff. This same technology also makes it possible for the ITTA audit and enforcement divisions to identify suspect claims. Thus, people deliberately or negligently filing erroneous claims run a very high risk of detection, much higher than if auditing targets were selected on a completely random basis.

As might be expected, there is a high level of compliance with the loss redistribution system, as well as the other parts of the income tax and transfer system. Although audits frequently turn up minor errors and discrepancies in the amounts claimed for economic loss, they tend to involve as much underpayments as overpayments.

\section{Expanded Powers of the Courts to Compel Present or Future Conduct}

With respect to grievances involving the continuing or future conduct of other people, the systems analysts developed a different approach. On the basis of their recommendations, legislatures greatly expanded the injunctive and supervisory powers of the courts. Not only did they confer new powers, they also equipped the courts with the personnel and technology to carry out these affirmative responsibilities.

The impact of this new approach has been felt most dramatically, perhaps, in the enforcement of private contracts. Breaches of contract are seldom addressed by damage actions in the twenty-first century. Instead, the agrieved party seeks to compel substantial performance. The court will send one of its "contract supervisors" to investigate the alleged breach. If satisfied of the breach at its hearing, the court will order performance of the contract. Only impossibility is a defense, and substantial or partial performance will be ordered, if appropriate. A "contract supervisor" will be assigned to monitor compliance with the order. 
Similar, although not identical, procedures are employed when the grievance is a consumer complaint about an alleged pattern of defective manufacture or unfair sales practices. Rather than relying on the incentive of damage actions to eventually induce the manufacturer or seller to correct its practices, the court investigates and, where appropriate, orders changes. Court personnel again follow up to insure compliance.

\section{New Policies for Status Changes}

Status changes are divided into several categories with each category treated somewhat differently. The underlying principle is to allow status changes without any judicial review whatsoever in any situation where all parties legitimately affected by the status change consent. Name changes by adults, for example, are allowed without any court action under the theory that no none else is affected sufficiently to allow him or her the right to prevent the name change. (Name changes must, however, be submitted to a computerized registry and also are published in a legal newspaper.)

Marriages can be terminated without judicial review if both husband and wife are in agreement as to the conditions of the termination, including child support, property division, etc. The couple merely fills out a simple form outlining the child custody arrangements and economic terms. The form is signed, witnessed and filed with a computerized national registry. These uncontested divorces represent over 90 percent of total marriage terminations in the twenty-first century.

Contested divorces present a somewhat different problem. Twenty-first century individualism holds that the spouse resisting termination of the relationship should not be allowed to prevent the other from changing their legal status. Personal freedom is valued above matrimonial stability. Still, the emotional and economic terms must be worked out. Thus, if one spouse resists an uncontested "divorce by registration," a sixty-day delay is imposed. The couple then is assigned to a special non-judicial forum, staffed by human relations specialists which endeavors to mediate settlement of the terms of the marriage dissolution. After the sixty days have elapsed, the marriage is terminated. In the vast majority of cases, the couple arrive at an agreement about economic and child custody issues which is incorporated into the divorce when it is registered. Only in the 
rare instances where they cannot be guided to a settlement does the court step in and impose a resolution of these issues.

\section{New Forums for the Remaining Disputes}

The remaining miscellany of disputes, many essentially emotional in content, are channelled to forums staffed largely by human relations specialists and citizens who have volunteered to sit on dispute resolution panels. In most respects, these forums resemble the "neighborhood tribunals" and "minor disputes tribunals" described in the maximum feasible deformalization scenario.

\section{B. What People Say About the "Systems Analysis" Justice System of the Twenty-First Century}

The systems analysis approach has resulted in a smaller judiciary and dispute resolution apparatus than the twentieth century version. Its supporters point to the favorable cost-benefit ratios. "We now handle loss compensation for an administrative cost of about one percent where the twentieth century approach took $20-50$ percent of benefits paid. And 90 percent of divorcing couples can do so at no cost to the justice system and little expense or aggravation for themselves. And in minor disputes we have forums that are calculated to resolve the problems between people, not just declare a 'victor' and wash their hands of the disputants like courts have done."

"It's too 'systematic,' too 'bloodless,"' respond some critics. "Nothing is left to chance or to choice. People are treated like automatons in some kinds of cases and like subjects of some experiment in behavioral psychology in others."

Another theme of complaint is that the system is undermining the sense of personal responsibility in the American populace. "You hurt somebody in an auto accident or you even slug him deliberately. Do you have to pay him for what you did? No! Do your insurance premiums even go up? No again! And why be careful yourself. If you're hurt skydiving, do you lose any money? No! Society does. It pays you while you lie in traction even though you're not contributing one iota to produce anything. It's all going to destroy the moral fibre of America. You can see it starting already. By the 
twenty-second century nobody will be doing anything. Everybody will be trying to live off their negative income and loss compensation payments."

\section{The Fourth Scenario: A "Lowered Expectations" Pro- GRAM}

(Note: The previous three scenarios, though differing rather dramatically in approach, have shared a common objective. All three have assumed society's commitment to equal justice for all and have sought to increase effective access to justice for all citizens and a broader range of disputes. This fourth scenario moves in the opposite direction.)

In the latter part of the twentieth century, a sustained drift to the right in American politics resulted in the election of a "lowered expectations" advocate to the presidency of the United States. As it had in past situations, the "lowered expectations" program translated into lower taxes, a smaller public sector and drastically reduced public services. Food stamp programs were abolished and welfare payments drastically curtailed in order that the more affluent people could buy more private automobiles, yachts, etc., with money that formerly went to the tax collector.

When legal services lawyers launched a series of court challenges to the new President's "lowered expectations" program, the White House led a successful legislative campaign to abolish the Legal Services Corporation, justifying this as an "economy move."

As the "lowered expectations" program gathered momentum, it focused on the justice system as one of the areas where drastic cuts could be made. "Our society is too litigious anyway. Every consumer and welfare recipient sues at the drop of a hat. Our country got along fine for nearly two centuries without class actions, legal aid, mediation centers, and all of that 'access to justice' stuff."

By the year 20??, the American justice system resembled the nineteenth century more than the twentieth. The last vestiges of free legal assistance had been routed out. Court fees were raised severalfold and in forma pauperis provisions were abolished. Thus, the courts did not have to bother with poor people or middle class people since they could not afford to pay the increased cost of 
litigation. The U.S. Constitution had been amended to remove any right to free counsel even for low income criminal defendants.

The statutes and court rules authorizing class actions have been repealed on grounds that such procedures merely allowed people to waste the court's time with minor grievances and, more significantly, to harass corporations and government officials. Rules governing standing have been tightened, and the courts' powers to grant relief have been limited in many categories of disputes. For instance, courts can no longer enjoin corporations or governmental bodies from carrying out activities even when judges find those activities to be inconsistent with the law. Sovereign immunity has been reestablished in toto. Consequently, government is immune from suit for any personal injuries or other damages it might inflict on private citizens. The only exception is for business enterprises that may sue for economic loss sustained because of governmental activities.

In order to further reverse the twentieth century trend toward overuse of the justice system, the government has enacted a series of statutes governing the private legal profession. Contingent fees have been outlawed. More than that, federal legislation prohibits lawyers from postponing payment of their fees until the lawsuit's outcome is known. The lawyer must bill for the work on an hourly basis and receive compensation in a timely fashion during the course of the lawsuit. This requirement is intended to discourage lawyers from "carrying" people in personal injury or other damages action who "in ordinary circumstances" would not be able to file suit and thus tie up valuable court resources. Other statutes outlaw pre-paid legal insurance and deny tax deductions from contributions to non-profit organizations that devote any resources to any litigation or advocacy activity other than that related to preservation of the non-profit organization itself. As a result of this ban, and the general mood of the country, none of the public interest law firms created in the mid and late twentieth century have survived. The American Civil Liberties Union and the NAACP, Inc. fund are but shells with small offices and a few volunteer lawyers handling a handful of cases each year.

Another facet of the "lowered expectations" program also has had an impact on the courts. In fact, one of the earliest targets of the "lowered expectations movement" was government regulation of private business. "Initiative, innovation and productivity are being buried in an avalanche of government paperwork. Free private enterprise from the bondage of government red-tape," became the 
battle cry of the "lowered expectations" militants. As a result, in the year 20?? there is no Federal Trade Commission, Civil Aeronautics Board, Nuclear Regulatory Agency, Interstate Commerce Commission, or similar offspring of the early twentieth century fear of robber barons and big business abuse. A secondary by-product of the absence of governmental regulation is that the court system no longer has to deal with enforcement actions or legal challenges arising from the regulatory work of these now defunct agencies.

Another related part of the "lowered expectations" legislative package has had a similar impact on the justice system. The federal government, as well as most state governments, has abolished its various welfare programs entirely, along with. Medicare and Medicaid. The Social Security program also has been eliminated except for some minimal payments to retired workers who made contributions to the fund before termination of the program in 20?? As a result of the elimination of virtually all of the transfer payment programs, the hundreds of thousands of appeals from disappointed applicants no longer must be dealt with through administrative adjudication or the courts.

There is no doubt the "lowered expectations" program has had the desired impact on the justice system. Caseloads have fallen dramatically. And the composition of the remaining caseload is of higher "quality." Court workload consists primarily of contract actions between business enterprises, libel suits involving wealthy individuals, probate cases, and divorces involving upper-middle class and wealthy couples. Only a few personal injury actions are heard: those arising out of accidental injury to well-to-do individuals.

During the past year, there have been three explosions at unregulated nuclear power plants in the United States and ten crashes of America's unregulated widebodied rocket planes. These accidents resulted in the death of over twenty thousand people and serious injuries or serious radiation exposure to another sixty-five thousand. But fortunately for the American justice system, only a fraction of these victims possessed sufficient means to afford to bring damage claims to the courts.

Workmen's Compensation Boards, of course, have been abolished since Worker's Compensation Insurance has been done away with. People hurt on the job are expected to file personal injury suits in the regular courts. However, only the upper strata of employees, chiefly management level, can afford to bring a damage 
case to the courts. Consequently, this form of litigation does not occupy much in the way of court resources.

Divorce cases are still a major drain on the judicial system. However, only upper-middle class and wealthy couples can afford the luxury of divorce. Consequently, over 40 percent of American citizens are living with someone other than their legal spouses.

Millions of landlord-tenant and credit collection cases are filed as a matter of fact, several times more than before the "lowered expectations" adherents achieved power. Yet these millions of cases do not even begin to make a dent in court resources, since they are almost never contested. Tenants and debtors cannot afford to defend; hence, these filings can be handled on a mass production basis by the courts.

It is now the fourth year of the new President's first administration and also the fourth year in which his "lowered expectations" political forces have had control of the U.S. Congress and most state governments. In a recent special television address to the nation from the Oval Office, the President extolled the progress his government has made in revamping the nation's justice system:

When my administration first took office, this society was held in the vise-grip of the bloated, inefficient, slow "imperial judiciary." It was only the most visible part of a gigantic justice system overblown by its unrealistic expectations of equal justice for all. In just three-and-a-half short years, we have dismantled this threat to free enterprise and lowered its expectations.

As a result of our vigorous program, courts are now doing what they are supposed to do - putting criminals in jail as soon as possible and for as long as possible and deciding important disputes that might arise between our great productive commercial enterprises as expeditiously as possible. Gone are the environmental lawsuits that used to stop industrial development and roadway construction. Gone are the consumer class actions and products liability cases that forced American industry to waste resources on quality control. Gone are all the class actions that raised Americans' expectations to the point that groups of individual citizens thought that they were entitled to challenge the wisdom of their own elected government and, even worse, the well-laid plans of private enterprise.

We also have removed most of the trash from the nation's courts, all those lawsuits by people who have no better things to do with their time and money than draining the taxpayer's money away for legal proceedings and more judges and public defenders and all of that other extraneous paraphernalia. 
The American people have responded by lowering their expectations for the justice system to new lows. And I'm happy to report that it is all paying off just as we promised. Caseloads are down by 90 percent. Delays in the courts have been cut by 70 percent. No American jurisdiction following the "lower expectations" program has had to hire a new judge in the past threeand-a-half years, and most have been able to fire over half of the judiciary.

I intend to introduce legislation in the next session of Congress to amend the U.S. Constitution to allow us in the federal government to fire judges, too. Why should they have life-time appointments? Let's lower their expectations, too.

Guilty pleas are up to 99.5 percent of all defendants charged. Sentences have nearly doubled and our new program of converting court houses, public libraries, museums and art galleries into prisons has allowed us to reduce the per capita cost of imprisonment by 75 percent while achieving the equally important objective of lowering the average citizen's cultural expectations to a realistic level.

When we have lowered expectations as successfully in other fields as we have in the justice area, then and only then will I be satisfied. In the meantime, as I said in my inaugural speech, "onward and downward, America, onward and downward."...

Concern has begun to grow within the Administration about the fate of its "lowered expectations" program. Not long after the President's special message about the justice system, polls revealed that he had achieved a 99 percent negative rating with the American electorate and that only one senator and three congressmen from his party appeared to be leading in their races for re-election.

Rumors from the White House indicate the President and his chief advisors have decided to lower expectations in one more obvious area. "Elections are a terrible waste of the taxpayer's money," his chief advisor is reported to have said at a cabinet meeting. The President supposedly replied, "Worse than that, they only raise people's expectations to unrealistically high levels. Elections only make Americans think that government can do something to help them with problems like pollution, depression, shoddy merchandise [the President struck the table with his fist for emphasis at this point but the table collapsed] and... and... those kinds of problems." It is reported that the Press Secretary then asked, "But what if somebody sues us for not having an election? Doesn't the Constitution say we have to?" "Who's going to sue us?" the Attorney General re- 
sponded. "The only ones who can afford to now are all in our corner."

Some editorials in the "left wing press" have begun to rail about an impending crisis in American government because no elections have been announced yet for the fall of 20??. But meantime, courts have never operated more smoothly. Cases are numbered in the score where they used to be in the thousands. Judges are able to play golf on Tuesday and Thursday afternoons and tennis Wednesdays and Fridays. Waste and fumes pollute the environment, and half of the merchandise sold is defective or unsafe, yet gross industrial production zooms to record levels unimagined in previous decades. Meanwhile, those litigants that do reach the courts are extremely well satisfied with the speed and thoroughness of the hearings they receive.

And the nine justices of the U.S. Supreme Court, with no class actions or criminal appeals and very few Constitutional appeals to hear, have formed a string ensemble to while away the hours between the occasional petitions for certiorari they now receive. And so, in the twenty-first century, the Supreme Court can only fiddle while America.... 



\title{
CONDITIONS OF LEGAL AND POLITICAL CULTURE LIMITING THE TRANSFERABILITY OF ACCESS-TO-LAW INNOVATIONS*
}

\author{
by \\ ERHARD BLANKENBURG \\ Professor of Sociology, Free University Amsterdam \\ jointly with \\ UDO REIFNER \\ Dr. jur., Wissenschaftszentrum Berlin
}

\section{The Question to be Treated: How Far Are the "Three Waves" of the "Access-to-Justice" Discussion Specific TO THE AMERican Situation?}

A discussion among scholars is a social enterprise requiring organization. It becomes more difficult the more the enquiry crosses disciplinary as well as national boundaries. The "Access-to-Justice" Series manages to bridge the differences between the disciplines of jurisprudence, legal practice, sociology and anthropology, as well as the differences between national legal systems. Professor Cappelletti has, for purposes of discussion, very aptly ordered the different strands of thought which are gathered together in this enterprise into "three waves." This represents a needed and successful attempt at intellectual labelling: the introduction of some guiding concepts in an ever growing and diversifying scholarly world seems to be the only means of organization which can provide direction and purpose.

Nevertheless, the "three waves" terminology coined by Cappelletti refers to a succession of developments as they occurred in America, which had many effects on the European continent, but where, however, different conditions prevailed. Even in the U.S.A., the attempts at improving legal aid for the poor in the 1960's had

* This paper is based on our discussions in a project on demands for legal services which we are undertaking together with Irmela Gorges and Fritz Tiemann. The historical analysis has been presented by Udo Reifner in a paper on "The Ideology of Public Legal Advice in Germany from 1904 to 1936" (Berlin, 1978). For the interpretation given here Erhard Blankenburg takes all responsibility. 
their predecessors in developments dating from as early as the turn of our century. Reginald Heber Smith's classic book, Justice and the Poor (1919), ${ }^{1}$ developed most of the arguments for overcoming the barriers of access to law. Smith pointed to the first attempts at organizing legal aid by German immigrants in New York, who tried to help their fellow countrymen manage some of the problems they faced as newcomers in the New World. That it was Germans who brought to the new country this belief in legalism was not mere accident: in Germany at the same time (around the turn of the century) legal aid's institutional infrastructure was growing rapidly. However, not much of that is reflected in the Germany of today.

The legal aid societies of the turn of the century, as well as the classic arguments of R. H. Smith, were rediscovered in the U.S.A. in the 1960's. That is to say, they had a recurring, not a continuous impact. The same cannot be said of the legal aid movement in Germany even though it gained considerable strength in pre-World War I times. As a means to meet some of the problems of the emerging working class, trade unions instituted legal advice centers for their members as early as 1890 . These were soon followed by charitable legal aid institutions established by churches and, later, by public institutions set up by local government. The competition between private and public legal aid societies in the German Reich of the early 1900 's mirrored exactly the competition among societal forces for dominance in the ideological developments accompanying industrialization. However, the pre-World War I legal aid institutions experienced only a brief revival in the Weimar Republic, were corrupted later for the corporative purposes of the fascist state, and were forgotten following World War II in both of the regimes which succeeded to the German Reich. While in the United States discussion about, and concern with, the legal problems of the poor experienced a Renaissance in the 1960 's, no similar developments of any significance have thus far taken place in the legal profession in the Federal Republic of Germany.

In this paper, we propose, first of all, to indicate some of the sociological reasons for the lack of awareness of access-to-law problems in Germany in spite of its early legal aid tradition. Second, we would like to describe the succession of ideological stages in the dein 1964).

1 R. Smith, Justice and the Poor (New York, Carnegie Foundation, 1919) (reprinted 
velopment of the legal aid movement in Germany (drawing largely upon a content analysis of legal aid journals). And, finally, we shall draw some conclusions as to the form which legal aid should take if it were to be institutionalized in the Federal Republic of Germany under the present conditions. We hope that this treatment will shed some light on the transferability of institutions from one legal culture to another, as well as contribute to the discussion on the "third wave" of the "access-to-justice" movement.

\section{The Social Conditions of the "Access-to-Law" Move- MENT}

\section{A. The Innovative Cases: The U.S.A., England, and the Netherlands}

The discussion on "access to justice" in the 1960's and 1970's was dominated by Anglo-American scholars. Propelling this discussion was a pragmatic interest in the innovation of institutions: the oldest and most far-reaching example being the development of legal aid and of neighborhood law centers in England, ${ }^{2}$ and the most widely publicized examples being the "legal services" movement of the American "War on Poverty" in the 1960's ${ }^{3}$ and the diverse continental attempts to import legal aid schemes and neighborhood law centers (the most successful being the Dutch attempt, which, in turn, has been imitated throughout Belgium, France, and even Switzerland). ${ }^{4}$

We might consider this movement as constituting a response to some of the challenges faced by post-industrial Western countries. The most apparent of such challenges, judging from the clientele of neighborhood law centers in London, Los Angeles or Amsterdam, is the problem of urban slum populations. England, the United States, the Netherlands, and the French-speaking countries on the European continent, experienced a massive economic immigration during the 1978).

2 See M. Zander, Legal Services for the Community (London, Temple Smith,

3 See E. Johnson, Jr., Justice and Reform - The Formative Years of the OEO Legal Services Program (New York, Russell Sage Foundation, 1974).

4 See, for the Netherlands, K. Schuyt, K. Groenendijk \& B. Sloot, De Weg naar HET REcht, especially at $35-42$ (Deventer, Kluwer, 1976); for France, BoutiQUES DE DROIT (Paris, Solin, C. Revon ed., 1978). 
1950's and 1960's. Immigration from Latin American countries to the United States, from former Asian colonies to Great Britain, from Indonesia to the Netherlands and from Northern Africa to France and Belgium can be considered as the latest consequence of an imperialistic past, even though they are not restricted to immigrants coming from former colonies. Since these largely unskilled, nonCaucasian workers had access only to low-paying jobs, and since they settled mainly in heavily populated industrial areas, they aggravated the problems of urban infrastructures, which were worsened by the flight of the native population to suburbia. Retaining the traditional family structures and cultural ties, the immigrant quarters in big cities tendend to become ghettos with massive problems of unemployment, crime and increasing cultural and economic deprivation compared to the absorbing (or rather non-absorbing)indigenous population.

In the 1970's, all these countries introduced stricter measures to govern and prevent immigration, thus increasing the penetration of legal controls by adding the administration of immigration to that of unemployment. Legal controls also entered into the regulation of public welfare, and their scope and importance grew with increasing landlord-tenant problems and with racial tensions developing in the emerging slums. No wonder that the counterpart of this increasing legalistic control was the development of legal aid institutions whose aim was to defend the poor by legal means against the controlling institutions.

Immigration problems, however, are not the only ones explaining the first wave of new legal aid institutions. They account for some specific forms of legal aid, such as "neighborhood law centers," but they do not account for the growth of other legal aid schemes in England, or "judicare" in some of the more rural parts of the U.S.A. Legal aid has been a broader movement, answering different sorts of latent needs in different social environments.

Nevertheless, legal aid institutions have been imitated across social (and national) boundaries, and they have undergone a historical evolution from innovative beginnings to more stable and more everyday activity. The developmental cycle from early innovativeness to institutional routine, which the legal aid movement of the American Office for Economic Opportunity (OEO) experienced, resembles what Max Weber (with respect to charismatic leadership) called the process of "Veralltäglichung." When the Legal Services Corporation 
was founded in 1974 in Washington, many of the former participants in OEO Legal Services saw this as the end of the "War on Poverty" attempts to fundamentally improve the situation of the poor by legal means. However, while the enthusiastic expectations of the innovative years may have waned, the Legal Services Corporation Act nonetheless signifies a stabilization of institutions which provide "legal assistance to those who would otherwise be unable to afford adequate legal counsel." In 1977, for example, it funded 320 legal services programs operating in about 700 neighborhood offices throughout the U.S. ${ }^{5}$ The bar had accepted in principle the need for specific forms of legal services aimed at specific legal needs - even though local bar associations in some places were still afraid of any competition by federally subsidized lawyers.

Routinization of the legal aid movement was accompanied by a broadening conception of the need to which the Legal Services Corporation should respond. We can characterize this process as general to post-industrial societies: informal ways of insuring against life's risks are increasingly replaced by formal ones. With the erosion of the economic function of the family, the individual is increasingly dependent upon larger organizations, e.g., for social security, health insurance and unemployment benefits. The lower social classes are especially deprived of the possibility of attaining their rights from the public administration, big employers or housing corporations. Civil courts have in fact been used more often to uphold the claims of big organizations against individuals, rather than to defend the rights of individuals.

Whereas traditional lawyers, who have customarily been preoccupied with the legal problems of the property-owning middle classes, are ill-prepared to advise the poor on their needs, neighborhood law centers have compensated for the lack of services for the lower classes, and they have taken up issues which might not pay sufficiently for a business-minded lawyer. Subsidized legal services have developed areas of legal activity which subsequently could also be serviced by regular lawyers. Rather than competing with traditional lawyers, they have performed the function of exploring new "markets" for lawyer services.

Similar arguments can be put forward with respect to the development of legal aid in England, in the Netherlands and in Swe-

5 Legal Services Corporation, Annual Report 1977 (Washington, D.C., 1978). 
den. Today, about half of the court-related income of barristers in England stems from legal aid clients. This business has not replaced that of a formerly private clientele, but has brought largely additional income to the barristers' offices. The same holds true for the "second wave" of the American "access-to-justice" movement: public interest issues considerably extend the scope of lawyer activity and can thus be explained by (among other reasons) the self-interest of the profession in developing new "markets" for their services.

In examining the changes in the infrastructure of legal services and in looking for the social conditions which explain them, we shall therefore adopt two ways of analyzing them: 1) as a response to social problems and a demand for legal help, and 2) as a supply of services made possible because the legal profession is interested in offering them. Thus, we shall try to explain the rise of the legal aid movement and its routinization by:

- an increasing demand for defensive legal action in a world which is increasingly regulated by large organizations, administration and, consequently, by legal regulations; and

- the (objective) interests of a growing legal profession in finding additional areas of competence and in diversifying its services (even where such interests are not subjectively perceived by much of the established bar).

\section{B. A Conservative Case: The Federal Republic of Germany}

Both of these social conditions hold true for all Western post-industrial countries. However, while some countries have pioneered the development of legal aid after World War II, others (such as the Federal Republic of Germany) have maintained a very conservative policy with respect to access to the legal system. Can it be that the social conditions which led to the development of legal aid in AngloAmerican countries are absent in Germany, or are there other factors which prevent innovation in Germany's legal institutions?

German lawyers sometimes justify the non-activism of German legal aid policy by referring to traditional institutions. They point to "Armenrecht," a provision of the Code of Civil Procedure of 1877 which allows the courts to cover the court costs and attorney's fees of parties who cannot afford those costs themselves, upon the con- 
dition that their cases have some likelihood of success in court. ${ }^{6}$ Lawyers for some time complained that their remuneration in such cases was lower than that in ordinary cases, but they achieved an upgrading of their Armenrecht fees to the normal rates in 1972. ${ }^{7}$ However, this could hardly be called an access reform, since it makes no attempt to improve the availability of pre-court counselling and fails to reflect the institutional difficulties of mobilizing the law for cases in which the party is unaware of his rights or does not know how to use them. Armenrecht is available only after a lawsuit has been filed, and using it requires legal information; it presupposes existing contacts with legal counsel rather than encouraging new ones. Consequently, it has been used rarely, and, even then, mainly in divorce cases where the parties are compelled to proceed legally and to consult lawyers (Hamburg being an exception with its Public Legal Advice and Mediation Center (ÖRA), which provides its clients with information and access to Armenrecht in cases involving a number of other issues). ${ }^{8}$

Although the prevailing consensus among German lawyers has been one of satisfaction with the modest and inefficient subsidization of court cases by means of Armenrecht, ${ }^{9}$ there have been some attempts at a more far-reaching "access-to-law" policy. ${ }^{10}$ Lawyers in the Social Democratic Party have been the leading proponents of establishing more public legal advice offices along the lines of the "ÖRA" in Hamburg (Berlin also has a traditional local government scheme for providing legal advice). The (voluntary) Bar Association

6 Sections 114-27 of the Code of Civil Procedure.

7 Up to an amount in controversy of DM 3,200, the Armenrecht fees of lawyers are equal to their normal fees; beyond that, they still are lower. See Law of October 24, 1972, [1972] BGBl. I 2013, also cited in Cappelletti \& Garth, Access to Justice: The Worldwide Movement to Make Rights Effective: A General Report, in Access to Justice: A WORLd Survey 24 (Alphen aan den Rijn/Milan, Sijthoff and Noordhoff/Giuffrè, Vol. I of the Florence Access-toJustice Project Series, M. Cappelletti \& B. Garth eds., 1978).

8 Falke, Bierbrauer \& Koch, Legal Advice and the Non-Judicial Settlement of Disputes: A Case Study of the Public Legal Advice and Mediation Center in the City of Hamburg, in Access to Justice: Promising Institutions 103 (Alphen aan den Rijn/Milan, Sijthoff and Noord hoff/Giuffrè, Vol. II of the Florence Access-to-Justice Project Series, M. Cappelletti \& J. Weisner eds., 1978/1979).

9 See G. Baumgärtel, Gleicher Zugang zum Recht für Alle (Cologne, Heymanns, 1976); W. GRUNSKy \& N. TROCKER, EMPFEHLEN SICH IM INTERESSE EINER EFFEKTIVEN RECHTSVERWIRKLICHUNG FÜr ALle BÜrger ÄNDERUNGen Des Systems des KostenUND GEBÜHRENRECHTS? (Gutachten A and B of the 51st Deutscher Juristentag) (Munich, Beck, 1976). Politik 98.

Arbeitsgemeinschaft Sozialdemokratischer Juristen, 1974 Recht und 
has reinforced its pro bono work provided at special hours in the local courts (Amtsgerichte), and some of the Länder (Bavaria and Saarland being the most widely publicized) have offered counselling services in their courts as well. ${ }^{11}$ The Federal Government took these "model experiments" as a basis for a proposed "Law on Legal Aid" which in 1980 has been enacted by Parliament.

This Parliamentary action reflects an awareness of the access-tolaw issue thirty years after the English legal aid scheme, twenty years after the American "War on Poverty" and ten years after the first Dutch "wetswinkels." However, these attempts at improving access to the legal system are exclusively directed at lowering the cost barriers for people with low or moderate economic means. They do not address any of the informational and social barriers involved in access; instead, they increase them by creating bureaucratic procedures for checking the entitlement of individuals who apply for public legal aid. The discussion among German lawyers has not yet taken notice of the different social problems which legal aid schemes in other countries have brought before the courts, nor has it reflected the need to offer a different kind of institution (starting with the physical location and lay-out of offices), which like the "neighborhood law centers" would lower the barriers of access for lower class clients.

Trying to explain this difference in awareness brings us back to the historical conditions which led to the "charismatic phase" of legal services in the U.S., England and the Netherlands. Some of the social problems which have beset these countries are far less serious in the Federal Republic of Germany. For instance, there has been no urban immigration comparable to that in the post-imperialistic countries to speed up local innovations. Germany is free of any significant colonial past, and its immigrant labor force throughout the nineteenth and the beginning of the twentieth centuries was drawn from Eastern European countries. After World War II, Germans experienced a forced remigration, followed by a twenty-year period of slow economic and political migration from East to West. Consequently, the Federal Republic of Germany was very late in en-

${ }^{11}$ For Berlin, see Reifner, Unentgeltliche Rechtsberatung in West-Berlin, in 5 JAHRBUCH FÜR RechtSSOZIOLOgIE UND RECHTSTHEORIE 43 (Wiesbaden, Westdeutscher Verlag, E. Blankenburg \& W. Kaupen eds., 1978). For the ÖRA, see Falke, Bierbrauer \& Koch, supra note 8; Falke, Zugang zum Recht - Eine Fallstudie über die Öffentliche Rechtsauskunfts- und Vergleichsstelle in Hamburg, in 5 JAHRBUCH FÜR RECHTSSOZIOLOGIE UND RECHTSTHEORIE, supra this note, at 11. 
couraging immigration from the Mediterranean countries: starting in the late 1950's there was a succession of, first, Italian workers coming to southern Germany, later, Yugoslavs and, to a lesser extent, Greeks and Spaniards, and finally; in a large wave, Turkish workers. With each successive immigrant group, there has been a progressively widening cultural gap between the Germans and the immigrants, and the immigration movement has reached further and further into the north of Western Germany (including West Berlin). Although there were some indications of slums (mainly Turkish) beginning to form in Berlin and in the heavily populated and industrialized Ruhr and Rhein/Main areas, the unemployment shock of 1973 led to an immediate stop to further immigration. Since the influx of foreign workers from the Mediterranean has always been administered and controlled by the Federal Employment Agency of Germany, it could be halted drastically in response to changing employment policies. There was a last wave of family members immigrating from 1973 to 1975 , but, as a whole, foreign worker employment decreased from 2.8 million in 1973 to 1.8 million in 1978. (With the increased immigration of nonemployed family members in the last stage, however, German politicians at the end of the seventies for the first time saw themselves confronted with hard-core immigration problems similar to those of their Western neighbors.) Until the late 1970's, one could say that the Federal Republic of Germany managed to administratively control the immigration movement and, accordingly, to keep out many of the resulting social problems. While the social and legal problems of integrating the immigrant population are still an important political issue, the social deprivations entailed are far less than those experienced in our Western neighbors as a result of their immigration problems. ${ }^{12}$

Nevertheless, even if comparable social problems of urban poverty and immigrant slums are lacking in Germany, this alone cannot explain the absence of a legal aid movement. It would be an oversimplification to attribute the "access-to-law" movement in AngloAmerican countries and on the continent wholly to the urban problems caused by immigration (even though this might have given the movement its most dramatic impetus). In England, legal aid started at the same time as the local "Citizens' Advice Bureaux," which were designed originally to help reintegrate soldiers returning from

12 See the documentation in G. BAumgärtel, supra note 9, at 43-56. 
World War II; and, for the most part, the "second wave" of representing diffuse interests by legal means responded to social problems of the indigenous population, largely of its middle classes. "Public interest law" is restricted neither to large metropolitan areas nor to the problems of their immigrant populations. It deals with the problems of consumers, of persons affected by administrative action, and of residents in total institutions such as mental hospitals or homes for the aged. It champions the causes of underprivileged groups such as workers and tenants, but it also extends to such general diffuse interests as consumer and environmental protection.

Although such "diffuse interest" issues are universal to all postindustrial countries (and not only the Western ones), their representation through a "public interest law" movement is specific to the American legal tradition. It is a movement which needs lawyer elites (or rather counter-elites) as protagonists, and which has developed around such legal institutions as adversarial litigation and case law traditions, and such specific instruments as class actions and bargaining justice. Public interest law firms have been promoted by liberals in the law schools and financed by research foundations; they are embedded in the genuinely American set-up of lobbying institutions, which perform some of the functions that the party system serves on the continent. Thus, if we compare our countries, differing legal as well as political institutions explain why similar interests are represented in different ways. Lawyers in the Federal Republic of Germany also take part in public interest campaigns, but they are not as prominent in them, and their means are not predominantly legal, as in the American "public interest law" movement. Environmentalists, in particular, and people objecting to town planning, nuclear energy or industrial investment in Germany organize around spontaneous action groups (Bürgerinitiativen) which use political pressure inside and outside of the established party organizations in addition to the formal legal means of administrative complaints and procedures. Litigation (especially before administrative courts) is only one of their means, and is usually a last-ditch attempt to prolong the decision-making process and thus to make it more costly. Consequently, "public interest issues" in Germany are seen as a challenge to the established political parties, not as a movement which changes the patterns of access to law. ${ }^{13}$

13 See Gastarbeiter in Gesellschaft und Recht (Munich, Beck, I. Ansay \& V. Gessner eds., 1974). The extent of legal deprivation of foreign workers in West Berlin is currently 
Similarly, what Cappelletti, with respect to the American situation, calls the "third wave" of the "access-to-justice" movement involves primarily problems specific to the American legal tradition. Even though there are complaints about the long duration of lawsuits before German courts, ${ }^{14}$ these courts appear as models of speed and efficiency if compared to American courts. ${ }^{15}$ Institutional and procedural innovations, such as the "Stuttgart Model" for handling civil cases, have been effective in reducing the German judges' preoccupation with the written files of a case and in involving to a greater extent the parties in the oral proceeding, speeding up lawsuits (even further) and encouraging settlements rather than going all the way to a final judgment. ${ }^{16}$ These innovations are within the scope of procedural discretion. Other innovations, such as the delegation of judicial powers to para-professionals like the Rechtspfleger, are a step towards treating routine cases bureaucratically. ${ }^{17}$ One of the procedures entrusted to the Rechtspfleger, the German dunning process (Mabnverfabren), is a bureaucratic procedure for providing creditors with a legal title to collect debts - an automatic legal stamp without substantive control unless the debtor lodges an opposition and thus calls for a lawsuit to clarify the case. It is a pre-court institution to enforce small (and large) liquidated claims, rather than an encouragement to contest them.

Thus, German courts are, to a large degree, part of an institutional set-up which leaves the individual with no choice but to defend by legal means - if he/she knows how to go about it. It is more speedy and more efficient than the judiciary in many other countries; it employs many more judges but considerably fewer at-

being studied by Ulrich Spies at the Wissenschattszentrum Berlin, with a report forthcoming in 1980.

14 See the court file studies, Rechtstatsachen zur Dauer des Zivilprozesses (erste Instanz) (Cologne, Heymanns, G. Baumgärtel \& P. Mes eds., 1971); Rechtstatsachen zUR Dauer des Zivilprosesses (zweite Instanz) (Cologne, Heymanns, G. Baumgärtel \& G. Hofmann eds., 1972). See also the evaluation (by Blankenburg, Morasch, and Wolff) of these data in Volume I of Tatsachen zur Reform Der Zivilgerichtsbarkeit (Tübingen, Mohr, 1974), which can be compared to data for the U. S. in H. Kalven \& B. Buchrolz, Delay in Court (Boston, Little, Brown \& Co., 1959), or for Italy in C. Castellano, C. Pace \& G. Palomba, L'efFicienzia della giUstizia italiana e I sUOI efFetTi economico-sociali (Bari, Laterza, 1968).

15 See Volume II of TATSAChen zUR Reform Der Zivilgerichtsbarkeit, supra note 14, at Part I (Strukturanalyse der Zivilgerichtsbarkeit) (by Blankenburg, Morasch, and Wolff).

16 Bender, The Stuttgart Model, in Access to Justice: Promising Institutions, supra note 8 , at 431 .

17 See Bender \& Eckert, The Rechtspfleger in the Federal Republic of Germany, in Access to Justice: Promising Institutions, supra note 8 , at 477 .

16. 
torneys than do the English or American legal systems. Comparative indicators show that the organization of its output side is much more developed - and the organization of its input side much less developed - than in other Western legal systems. ${ }^{18}$

This situation is the more astonishing since the German legal system at the turn of the century had a very elaborate system of legal aid institutions. We shall have to look at the social conditions accompanying this early "legal aid" movement in Germany, its history and the events which led to its breakdown, and, finally, at features of its legal culture which might explain why there has been no revival of legal aid institutions thus far in the Federal Republic of Germany,

\section{The German "Peace-under-the-Law" ("Rechtsfriede") Movement as an Attempt to Pacify the Social An- TAGONISMS OF INDUSTRIALIZATION}

\section{A. Legalization of Social Disputes by Free Legal Advice}

One side of our argument is that "legal aid movements" do not emerge except as a response to some social issue. At the end of the nineteenth century, the German Reich was experiencing industrialization and the rapid rise of a workers' movement. Compared to England, industrialization came late in Germany; and, especially in Prussia, it was characterized by the alliance of big landowners, big industry and the state. Workers' unions as well as workers' parties were repressed by economic as well as legal means: when in 1878 Bismarck outlawed "all associations which aimed at overturning the order of the state and society by social democratic, socialist or communist means," this was only the highlight of the legal repression of the workers' movement. At about the same time, however, he introduced the illness insurance law in 1883, the accident insurance law for industrial workers in 1884, and insurance for retired and handicapped people in 1889. All of these were attempts to solve social

18 See E. Johnson, Jr., S. Block, A. Drew, W. Felstiner, E. Hansen \& G. Sabagh, A Comparative Analysis of the Statistical Dimensions of the Justice Systems of Seven Industrial Democracies (report submitted to the National Institute for Law Enforcement and Criminal Justice, 1977). 
problems of the industrial proletariat, and to prevent it from organizing in socialist parties and unions. ${ }^{19}$

In this way, the Prussian state in the time of Bismarck became a forerunner in social policy, and it managed to prepare the workers' movement for making peace with the state. When by 1890 the Social Democratic Party won a success in the general elections (in which they were still allowed to participate), the anti-socialist law had to be dropped, but the social security legislation remained as a feature of a paternalistic state being above the antagonism of class interests. ${ }^{20}$

In the early days of social welfare legislation, the task of giving advice as to these new rights (granted under the social security laws, the installment credit protection act (1894) and the labor protection acts (1891)) was undertaken by the workers' secretariats of the unions. ${ }^{21}$ When 226,260 persons sought advice from the 48 workers' secretariats in 1904, bourgeois politicians recognized that legal aid for the workers would be a necessary part of their attempt to integrate the working class through social policy institutions. The former Minister of Trade, Möller, expressed the public opinion when he stated in the Prussian Parliament: "The propaganda activities through legal counselling administered by the Social Democratic Party are exceedingly vast, exceedingly intensive and exceedingly effective, and we would be gravely negligent if we did not satisfy this need in a different way." 22 With the support of the Government, local communities and denominational nonprofit organizations instituted legal aid offices which offered free legal advice to all citizens. ${ }^{23}$ In 1906, the Association got more grants than it could spend. ${ }^{24}$ In the legal advice centers laymen worked with public

19 Die Geschichte der Berliner Arbeiter-Bewegung (Part three: 15 Jahre Berliner Arbeiterbewegung unter dem gemeinen Recht) (Berlin, "Vorwärts," E. Bernstein ed., 1910).

20 F. Neumann, Behemoth: Struktur und Praxis des Nationalsozialismus 1933. 1944 (Cologne and Frankfurt a.M., Europäische Verlagsanstalt, 1977) (first published 1944).

21 Reifner \& Gorges, Alternativen der Rechtsberatung - Dienstleistung, Fürsorge oder Kollektive Selbstbilfe, in 6 JAHRBUCH FÜR RechtssozIOLOGIE UND RECHTSTHEORIE 233 (Wiesbaden, Westdeuscher Verlag, E. Blankenburg, E. Klause \& H. Rottleuthner eds., 1979); A. Soudek, Die deutschen Arbeitersekretariate (Leipzig, Jäh \& Schunke, 1902); A. Müller, Arbeitersekretariate und Arbeiterversicherung in Deutschland (Munich, Birk, 1904).

22 Brunner, Die deutschen Arbeitersekretariate in Jabre 1905, 1906 CoRRESPONDENZBLATT der Generalkommission der Gewerkschaften Deutschlands 401.

23 See Link, Recbtskonsulenten und Rechtsauskunftstellen, 1907 DiE ArbeITERversorGUNG 173-74 (No. 9 from March 20, 1907); Juristische Rundschau, 1907 Deutsche JuRISTENZEITUNG 576 and 1362

${ }^{24}$ Link, Report of the Association of Nonprofit and Nonpartisan Legal Advice Centers from 1913 to 1920, in 1920 Die Gemeinnützige Rechtsauskunft 61 et seq. 
functionaries, especially those who were concerned with legal affairs in public administrative courts. The legal advice was to be given in an objective and nonpartisan way. The goal of counselling was to maintain social peace and to prevent "unnecessary litigation."

Legal Aid in Germany 1912: Number of Offices and their Activities

\begin{tabular}{|c|c|c|c|c|}
\hline & & $\begin{array}{l}\text { Legal } \\
\text { Aid } \\
\text { Offices }\end{array}$ & $\begin{array}{l}\text { Number of } \\
\text { Counsellings }\end{array}$ & $\begin{array}{l}\text { Number } \\
\text { of Written } \\
\text { Actions } \\
\text { on Behalf } \\
\text { of Clients }\end{array}$ \\
\hline I. & Public Legal Aid & 119 & 337,071 & 57,563 \\
\hline II. & Denominational Legal Aid & & & \\
\hline & 1) Protestant & 23 & 30,838 & 13,434 \\
\hline & 2) Catholic & 122 & 235,638 & 90,713 \\
\hline III. & $\begin{array}{l}\text { Legal Aid by Workers' Associations } \\
\text { 1a) Workers' Secretariats of the Free }\end{array}$ & & & \\
\hline & Trade Unions & 119 & 701,648 & 173,897 \\
\hline & $\begin{array}{l}\text { 1b) Legal Aid by the Trade Union Car- } \\
\text { tels }\end{array}$ & 211 & 51,772 & 18,748 \\
\hline & 2) Federations of Artisans (Deutsche & & & \\
\hline & Gewerkvereine) & 55 & 58,365 & 11,185 \\
\hline & 3) Christian Trade Unions & 55 & 40,056 & 22,490 \\
\hline & 4) Polish Occupational Union & 8 & 21,081 & 12,224 \\
\hline & 5) Other Workers' Associations & 6 & 3,166 & 1,516 \\
\hline IV. & Legal Aid by Associations of Employees & 23 & 58,703 & 1,319 \\
\hline & Legal Aid by Rural Cooperatives & 9 & 17,056 & 584 \\
\hline VI. & Legal Aid by Management & 9 & 12,461 & 5,017 \\
\hline VII. & Legal Aid by Political Associations & 32 & 33,732 & 14,463 \\
\hline VIII. & Women's Legal Aid & 93 & 45,485 & 8,859 \\
\hline IX. & Other Non-profit Organizations & 32 & 194,292 & 36,016 \\
\hline Total & & 916 & $1,841,364$ & 468,028 \\
\hline
\end{tabular}

Source: 1913 ReICHSARBEITSBLATt, Beiheft.

The competitive system of legal aid institutions led within a few years to an infrastructure of legal aid being provided by the associations of three of the main societal forces: trade unions, churches and 
public authorities. A survey also shows which types of legal issues were raised in the counselling activities: ${ }^{25}$

$\begin{array}{lr}\text { labor and apprenticeship contracts } & 15 \% \\ \text { other civil law } & 29 \% \\ \text { social security law } & 25 \% \\ \text { civil procedure } & 7 \% \\ \text { criminal procedure } & 5 \% \\ \text { public law } & 12 \% \\ \text { other } & 7 \%\end{array}$

As the survey demonstrates, the problems of the lower social classes were certainly overrepresented if compared to the legal matters normally handled by attorneys at that time. Labor law as well as social insurance issues had been alien to the lawyers' practice as well as to their training. Clearly, the legal aid institutions of the trade unions initially, but later public as well as denominational legal aid, helped to develop fields of law which otherwise would hardly have been implemented as early as they were in the German Reich.

\section{B. "Legal Welfare" as the Ideology of the "Peace-under-the-Law" Movement}

The willingness of German trade unions to take up the rights which had been given by the anti-socialist laws of the Bismarck period and to help their worker members to enforce their legal claims helped to integrate the German workers' movement into the overall governmental-legal system. This process did not go without opposition: many social democrats saw the law and the courts as a means of supression. The Erfurter Program of the Social Democratic Party in 1891 demanded legislation representing the interests of the people as well as courts with popularly elected judges. ${ }^{26}$ Both of the above-mentioned positions concerning the use of law for the workers' interests were increasingly revised under various pressures. In the "peace-under-the-law" ("Rechtsfriede") movement the different sides came to a formal ideological consensus.

251913 Reichsarbeitsblatt, Beiheft.

26 Das Erfurter Programm: Ein historisches Dokument (Munich, Verlag Das Volk, 1947). See also Eisenacher Programm der SPD, 1869 Demokratisches WochenblatT (Organ der sozial-demokratischen Arbeiterpartei, Leipzig) 374 (No. 33 of August 14, 1869) (reprinted 1969). 


\section{Welfare Capitalism and "Volksrecht" ("People's Law")}

Bourgeois politicians in Germany, following Bismarck's philosophy, realized very early that the uncontrolled power of a Manchester capitalism would lead to a dangerous growth of the workers' movement. ${ }^{27}$ But there was no consensus within the legal profession as to how the dispossessed classes could be reconciled with the state. While the prevailing Romanic tradition of jurisprudence looked upon labor law and worker protection laws as legal exceptions which should not disturb the legal system more than was necessary, there was, within the smaller fraction based on the Germanic law tradition, an anti-capitalistic criticism by conservatives longing for the restoration of feudalism and corporativism, which accepted the obligation of welfare for the poor, but at the same time excluded the "cultureless masses" from every political influence. Social capitalism and the welfare police state opposed each other in legal ideology. The ideal of subjective rights stood against the "Volksrecht" ("people's law"); the principle of free contract, against the principles of a corporative state. Both theoretical currents were the expression of the unique structure of the Prussian state, the power of which was based partly on a feudal agrarian economy in East Prussia and partly on a developed industry in other parts of the country. In this way, two power groups unified, and "the feudal bourgeois" 28 appeared on the political stage: formal and corporativistic ideology amalgamated within the "peace-under-the-law" movement. There was a consensus about the division of labor: attorneys should continue their independent and partisan work within the framework of their traditional clientele, while for the lower classes a new type of legal representation was created, i.e., "legal welfare," which was to be given free to everyone but should be impartial and orientated towards the public welfare.

These legal advice centers were to "popularize the law, encourage the understanding of the people for legislation, as well as mediate and prevent litigation." Representation of the clients of legal advice centers in court was excluded in principle (except for courts dealing with social security legislation, before which the unions had

27 See A. Menger, DAS bürgerliche Recht und die besitzlosen VolKsKLassen (Tübingen, Verlag der H. Laupp'schen Buchhandlungen, 3rd ed., 1904).

.28 F. NeumanN, supra note 20 , at 28. 
the right to represent parties). Thus, the public legal advice centers were from the beginning focused on extra-legal conflict resolution and on preventing a politicization of social disputes. "Not political propaganda, but legal advice and legal aid" 29 should be the task of the legal advice centers. Shortly after the First World War, the director and founder of the Association of Nonprofit and Nonpartisan Legal Advice Centers summarized the task of these centers as follows:

The worse the disorder and confusion, the more we have to lay the basis for reconstruction.... Nothing is more embittering than to be at a legal disadvantage. Therefore, if we want to free the masses from bitterness, if we want to give them a feeling of responsibility towards the public, we first have to secure the legal position of the poor.... Differences in wealth and education will never be totally equalized; differences in the legal position can be compensated for and have to be compensated for. This was true before the revolution and should be true even more now. ${ }^{30}$

The "revolution" after the breakdown of the monarchy in Germany led to the cooperation of leading Social Democrats with the military leaders. ${ }^{31}$ Having proclaimed the Republic, law and order were to be restored. Returning to work was again to become the first civic duty. This cooperative attitude of the workers' movement determined the functions of its legal aid activities as well: "The legal advice centers," according to Link, "have to work correctly and have a full understanding of the social conditions and needs of the poor classes; they should not be bureaucratic institutions finishing one case after another indifferently. There must also be a helpfulness, giving confidence to every visitor. Clients have to be treated politely and obligingly." 32

In 1920, about two weeks after the German unions succeeded by general strike in putting down the military coup by Kapp and thus saved at least the form of democracy, the following was contained in the principal speech at the assembly of the legal aid association:

291919 Die Gemeinnützige Rechtsauskunft 43.

30 Link, Die Gemeinnützige Rechtsauskunft in neuen Deutschland, 1919 Die GemeInnütZIGE RECHTSAUSKUNFT 71.

31 F. NeumanN, supra note 20, at 34-35.

32 Link, supra note 30 , at 72 . 
In our economy, which has been badly damaged by political turmoil and continuous strikes, all struggles and quarrels have to be avoided as much as possible. To heal the ailing body of the people [Volkskörper], all disturbances and excitement should be fended off from wherever they may come. The public legal advice centers can and shall participate in serving the peace under the law and in preventing litigation and the inherent struggles and agitation. They shall work towards social harmonization and the consolidation of the public sense of order.... and thus create the urgent moral rebirth of the nation. ${ }^{33}$

The "peace-under-the-law" movement increasingly developed into a movement for the appeasement of the interests of the socially underprivileged. This tendency was made all the more obvious through the ties of the public legal advice centers with the Association of German Banks and Bankers, which found a friendly acknowledgement on the occasion of the 25th anniversary of the Association of Legal Advice Centers. In 1933, moreover, the Association of German News Publishers, the Chamber of Commerce, and the General Creditors Association were among the corporate members of the legal advice association. ${ }^{34}$

\section{Social Reformism and the Ideology of Partnership}

The "peace-under-the-law" movement would not have had such a social success if it had not also had backing within the social democratic movement. At the beginning of the century, the workers' secretariats "had seen their task in giving the working people the most effective weapons to fight against the legal order, hostile to the workers," and had promised "to put all their strength into the liberation of the working class from the chains of an antiquated legal order." 35 Under the pressure of increasing demands for individual advice, however, they degenerated into a mere service delivery system for union members. Instead of defending the social interests of their members, they became more and more a form of administering to individual misfortunes by the means of the law. The polemical

33 Hüttner, Die gegenwärtige Lage der gemeinnützigen Rechtsauskunft und des Verbandes der Rechtsauskunftstellen, 1920 Die Gemeinnützige Rechtsauskunft 89, 92.

${ }^{34}$ Link, 25 Jabre Verband der Rechtsauskunftstellen, 1931 Die Rechtsauskunft 5.

35 Umbreit, Die deutschen Arbeitersekretariate im Jahre 1902, 1903 CORRESPONdenzblatt der Generalkommission der Gewerkschaften Deutschlands 401-08. 
annual reports presenting the individual grievances as part of a collective struggle were replaced by information about the amount of money which had been collected by legal means. The unions, which in 1906 had characterized the new public legal aid institutions as instruments "to perform anti-socialist and anti-union propaganda with the means of the state and the communities" 36 and had declined to found a legal advice center together with the city of Frankfurt because they wanted a "center to promote the class interests," 37 demanded in 1919 that their own institution and the city institution be incorporated into a general public "welfare office." 38 Some workers' secretariats even accepted the invitation of the public legal advice centers to merge with them: "Almost everywhere broad sectors of the bourgeoisie and the workers are cooperating in preserving law and order.... That raises the question whether under these circumstances the coexistence of public legal advice centers and the workers' secretariats is still necessary. Insofar as the workers' secretariats refrain from subsidiary political activities, there are no obstacles with regard to a merger with public legal advice centers." 39

In the official publication of the German unions in 1918, the only news about the workers' secretariats were complaints about bad pay, education, and office equipment. ${ }^{40}$ The Social Democratic Party and the unions had come to an accommodation with the official legal order at the very time that revolutionary workers and soldiers in Berlin, Hamburg, Kiel and Lübeck, as well as in the Ruhr district, wanted a socialist state. The leaders of the Social Democratic Party tried to legitimate their policy of legalization by extending it to a policy of social peace. They saw the enemy of democracy not on the right (from where it was to be destroyed thirteen years later) but on the left. Franz Neumann, an attorney at that time, described this during his American exile as follows:

The class struggle was to be replaced by cooperation between the classes - this was the goal of the [Weimar] Constitution.... The

36 Brunner, supra note 22.

37 A. SoudeK, supra note 21 , at 28.

38 Peikert, Die Sozialisierung der Arbeitersekretariate, 1919 KorRespondenzblatT DER Generalkommission Der Gewerkschaften Deutschlands 295, 296.

${ }^{39}$ Link, supra note 24 , at 67 .

40 See Peikert, supra note 38; Aufderstrasse, Unsere Arbeitersekretariate nach dem Kriege, 1919 Korrespondenzblatt der Geineralkommission der Gewerkschaften DeutschLANDS 252, 253; Die Zukunft der Arbeitersekretariate, 1919 KoRRESPONDENZBLATT DER Generalkommission der Gewerkschaften Deutschlands 553, 554. 
essence of the Constitution was the compromise between all social and political groups. With the help of political pluralism, which was the backbone of the form of parliamentarian democracy, antagonistic interests should be harmonized.... This theory had its roots in the interpretation of German legal history by Otto von Gierke, which was mixed in a strange combination with reformist socialism (Proudhon) and the social dogma of Neo-Thomism. ${ }^{41}$

This policy was represented in the "peace-under-the-law" movement by Radbruch, later the Social Democratic Minister of Justice, especially in his emphatic plea for mediation. ${ }^{42}$ Radbruch believed that the high value placed on a feeling of justice was a main problem of his time. He felt that there was "a far too irritable and litigious sensitivity" among Germans. Litigation was very often not aimed at solving conflicts, but was rather an act of redress as in a dispute about honor: "The judgment necessarily violates the honor of one party and adds to the hatred against the opponent the hatred against the state and its justice...." For Radbruch, law represented the society as a whole, for whom class antagonism either does not exist or must not be put into effect because it is dangerous for the development of the whole. Although he alluded to a national consciousness which is competitive and quarrelsome, he emphatically demanded a "national commonweal, which asks us to keep the sword of justice in the sheath by means of a civil mediation procedure." 43 Delegalization, which had been a demand under the conservative notion of legal welfare, was idealized by Radbruch: "Having not the task to apply the law but to make peace, the mediation procedure fulfills its goal when it leads to a settlement satisfying both parties to the litigation, regardless of whether the settlement proposal is based on principles of positive law or on other conceptions of justice." Legal norms are replaced by "norms of life." Radbruch praised the workers' secretaries as the predecessors of a new type of lawyer who serves both disputing parties. ${ }^{44} \mathrm{He}$ is "situated above the parties.... He does not serve the legal norm, the will of the state or an abstract

41 F. Neumann, supra note 20 , at 32-33.

42 Das Güteverfabren und das deutsche Rechtsgefühl, 1919 DiE GemeINNÜTzIGE Rechtsauskunft 39 et seq.

${ }^{43} \mathrm{Id}$. at 42.

44 Radbruch, Das Recht im sozialen Volksstaat, 1919 Die Gemeinnützige RechtsausKUNFT 95 . 
idea, but only the parties, the social classes to whom they belong and the whole society. It is not justice which is their ideal, but rather welfare in the framework of justice."

Radbruch joined a tradition of dispute resolution within the working class. At the beginning of the century, the workers' secretariats also defined their task as "warning the parties against petty quarrels and trivial matters and in protecting the workers as far as possible from loss of time and money, and from the costs of courts and attorneys." 45 This policy, however, only applied to disputes among workers, who were adverse to letting legal regulations interfere with the subculture of working class values. In relation to the class-opponent and to the state, on the other hand, they fought for clear legal positions. This is why we judge Radbruch's attitude as detrimental to the rights of workers: because the implementation of labor laws had to be fought out in court, case by case, against the customary determination by management of the conditions of work.

Fraenkel has pointed out that since the corps of judges in the German judiciary was very law-abiding, there were advantages for the working class in pursuing some of its interests by legalistic strategies. ${ }^{46}$

3. From the "Peace-under-the-Law" Movement to "National Socialist Legal Care"

In the postscript to a report concerning the legal advice center in Hamburg, written by a high functionary of the Federal Ministry of Justice in 1924, we find a remarkable vision. The author asks judges to take part in nonprofit public legal advice "in order to ensure that the people's need for mediation will not, in the end, lead to a movement for a new sort of special court with a complete exclusion of judges and attorneys." 47 The stated "need for a helpful mediator in order to guide and advise" was no more than the expression of social weakness following the complete legalization of social conflicts. The vision of special courts for particular types of people and the

45 Third Annual Report of the workers' secretariats in Nuremberg: see A. SoudeK, supra note 21 , at 33 .

46 E. Fraenkel, Zur Soziologie der Klassenjustiz (Berlin, Jungsozialistische Schriftenreihe, 1927).

47 Volkmar, Postscript to Islar, Die öffentliche Rechtsauskunfts- und Gütestelle in Hamburg, 1924 Deutsche Juristenzeitung 952. 
exclusion of ordinary courts and attorneys, and even of the law, for certain social groups was realized only ten years later for Jews, communists, and socialists.

At the end of the Weimar Republic, the public legal advice centers were not heavily frequented, but they were still supported by the state. Under a number of directives law clerks, assistant judges, public functionaries, and judges were allowed to give legal advice. Most of the advice was now provided in the areas of labor relations and landlord-tenant law, where antagonistic social interests had in former times been resolved through open dispute. ${ }^{48}$

"If the state takes care of all these things, what then is the use of the unions?" This was an oft-repeated question in Germany. The unions had been ideologically as well as practically disarmed by their integration into a pre-emptive system of cooperation and mediation. 49

From 1930 onwards, the bar was successfully integrated into the "peace-under-the-law" movement. At this time, the bar was experiencing a great economic crisis. Since 1923, the number of attorneys had risen from 12,729 to 17,220 , and the profession was not able to provide work for all these attorneys. New fields of activity had to be found. In 1930, the Council of the German Bar Association opened talks with the legal advice association in order to reach an agreement for the participation of attorneys in community public legal advice centers. ${ }^{50}$ There were some isolated warnings that the transformation of the advocate into an impartial representative of general interests in "legal welfare" would threaten the bar's function in society. ${ }^{51}$

But the National Socialists within the bar, represented in the talks by Jessen, a member of the Bar Association's General Council, submitted to the interests of the fascist state. The directives for legal advice, worked out jointly by the bar and the legal aid association, incorporated the notion of "legal welfare" as part of the work of the bar, stating that it could not "be denied that legal welfare has always been part of legal work and therefore in accordance with the essence

48 See Herrfurth, Gemeinnützige Rechtsauskunft und Rechtspflege, 1927 DeuTsche RiCHTERZEITUNG 433, 434.

${ }^{49} \mathrm{~F}$. Neumann, supra note 20 , at 470 et seq., 476.

50 Jessen, Rechtsauskunftstellen und Anwaltschaft, 1931 Die ReCHTSAUSKunft 6.

51 Fischer, Die Entwicklung der Rechtsauskunftstellen, Recht und Leben, Vossische ZeItung, weekly supplement, No. 6, April 16, 1931. 
of advocacy." 52 It was Jessen who made apparent the dualism in the legal order for rich and poor when he distinguished "advocacy" from "legal welfare":

Each actual advocacy starts from the idea of serving one party and is therefore governed by the relation of fidelity to one's client; legal welfare activity does not know such a connection to a single person, but aims to repair disturbed legal relations to protect the public from legal prejudice... in order to serve the state, the economy, and the public welfare.

With respect to the client, his rights (seine Recbte) were supplanted by the law (das Recht), which sought "to replace the legal solution by something better if necessary to prevent avoidable disputes." In this work the attorney was to "make it clear that it is not important to be in the right concerning one's own rights or the rights of others... but that the proper rights should be found in upholding the concrete law of a lasting peace.... The attorneypeacemaker thus becomes a genuine people's attorney [Volksanwalt]." 53 The ideology of a "genuine attorney of the people" became part of the National Socialist take-over of the legal system which took place in 1933.

Jessen, well known in the "peace-under-the-law" movement before 1933, attempted a verbal clarification according to National Socialist ideology:

We [i.e., the NS Lawyer Association] are, on the one hand, in a position to take over many ideas and concepts as well as many practical measures of former times and thus to build up our house [the NS society] on a broad foundation. On the other hand, the unalterable fact is confirmed that national renewal implies a fundamental change of views.

But, as a matter of fact, many of the ideological elements of "legal welfare" recurred, although expressed in a most crude way: "We do

52 See Grimm, Die Verhandlungen des Verbandes der Rechtsauskunftstellen mit dem Deutschen Anwaltverein über die Mitarbeit der Rechtsanwaltschaft bei der Rechtsfürsorge, 1932 Die Rechtsauskunft 33-39; Jessen, Rechtsfürsorge und Anwaltschaft, 1932 Die RechtsausKUNFT 39.

53 Klein, Rechtsfriedens-Anwalt, 1932 Die Rechtsauskunft 44. 
not want to nurture a nation of grumblers and gripers; those who are stubborn or vexatious shall not find additional support in their blameworthy behavior." 54

Legal care was to have an educational function for the public and was to be focused on legal peace activities. In 1934, after about two thirds $(13,000$ members $)$ of the bar, representing most of the non-Jewish membership, had joined (in part voluntarily, in part under pressure) the League of National Socialist German Lawyers (Bund Nationalsozialistischer Deutscher Juristen: BNSDJ), 55 the "Office for Legal Care of the German People" (Amt für Rechtsbetreunng des deutschen Volkes) was founded. All public legal care institutions were handed over to the BNSDJ under the supervision of this Office. At the same time (with a few exceptions such as the successors to the workers' secretariats in the NS Labor Front), all other legal aid institutions were outlawed because it was feared that they could have goals other than "legal peace" and "service to the law." 56

It must have appeared grotesque to the social democratic members of the "peace-under-the-law" movement that their former demands - for recognition of legal advice centers as official institutions for conciliatory proceedings according to sec. 495a of the Code of Civil Procedure and for the nationalization of all legal aid in a "public welfare office" - should be fulfilled by the NS revolution. In 1935, there were already 1,323 legal care offices in Germany, ${ }^{\mathbf{5}}$ whose advisors were attorneys of the BNSDJ and whose directors were named by the High Law Commissioner of the Reich. The offices had to document each case on a sheet of paper which had to be handed over to the Law Office of the Reich. Thus, the NS power had a widespread system of political information. Legal assistance

54 "I take it to be my task to make the bridge from the past to the future." Jessen, Rechtsberatung der deutschen Anwaltschaft, 1932 DIE RECHTSAUSKUNFT 125.

55 Schneider, Zur Notwendigkeit einer verfassungskonformen Auslegung des Rechtsberatungsgesetzes, 1976 Monatsschrift für Deutsches Recht 1; F. Ostler, Die DEUTSCHEN RECHTSANWÄLTE 1871-1971, at 100 (Essen, Ellinghaus, 1971); Reifner, Das System der Rechtsberatung in der Bundesrepublik Deutschland - Tendenzen und Probleme, 1976 JURISTENZEITUNG 504, 508.

56 Raeke, Die nationalsozialistische Rechtsbetreuung für alle minderbemittelten deutschen Volksgenossen, 1934 Juristische Wochenschrift 126; see also Raeke, Dienst am Recht, 1936 JURISTISCHE WOCHENSCHRIFT 1.

57 Eisenlohr, Die nationalsozialistische Rechtsbetreunng des deutschen Volkes, 1935 MrTTEILUNGSBLATT DES NATIONALSOZIALISTISCHEN RECHTSWAHRERBUNDES (supplement to 1935 Deutsches Recht) 125-127. 
was not available for any demands against the Party or the state, or any demands which were made by non-Aryans. ${ }^{58}$

After the bar as well as a large number of the judges had been taken into the NS system, the expulsion of Jews, communists, socialists, democrats, and other opponents of the Third Reich could be continued. First, all attorneys of the BNSDJ were threatened with expulsion from the Party if they defended a Jew in court, ${ }^{59}$ and the same sanction was prescribed for those who defended expelled Party members. ${ }^{60}$ In addition, a new "Law against Abuses in the Area of Legal Advice" (Gesetz zur Verbütung von Missbräuchen auf dem Gebiet der Rechtsberatung: RBerMG) provided the possibility of refusing admittance to legal counselling. It concluded the ideological integration of the bar into the "peace-under-the-law" movement with its NS ideology. At the same time, a monopoly on legal counselling, included in this "legal services law," rewarded lawyers for their ideological assent. The Nazis had amalgamated the "peace-under-the-law" ideology with the interests of the economically threatened bar. Excluding all but lawyers from legal advice, access to the legal system and the courts was in the hands of the bar, which the National Socialists had no difficulties in controlling.

\section{After 1945: Restricting Competition for Lawyers' Services}

After the breakdown of the German Reich in 1945, many of the traditions of the Weimar Republic were revived. The Federal Republic of Germany, which was founded in 1949 on the basis of a re-establishment of the administration and the political party system in the three western occupied zones, declared itself the successor of the Reich and re-enacted many of its laws. The law regulating legal services (RBerG) was among them. While historically it had been an instrument for excluding Jewish lawyers from the bar, its function was now seen in upholding professional ethics and in restricting competition from para-professional groups. The RBerG forbids legal counsel to be given in specific cases by anyone but lawyers. Excep-

58 See the Rules for NS Legal Advice, published in 1934 Juristische Wochenschrift 1001; see P. Grein, Die unentgeltliche Rechtsberatung Minderbemittelter in Deutschland 119 (Berlin, Junker und Dunnhaupt, 1937).

59 See F. Neumann, supra note 20, at 442, 657-58.

60 Circular No. 38/35, Mitteilungsblatt DES BNSDJ (Nationalsozialistischer Rechtswahrerbund), in 1935 Deutsches Recht 125. 
tions are permitted only where para-professional groups have the right to represent parties in court, as is the case for trade union secretaries or employers' associations in labor courts, for social work agencies in social security courts, etc. The right to give legal counsel in such cases is restricted to the legal matter for which the groups are explicitly permitted to appear in court. Thus, trade unions are not able to extend their legal services beyond labor and social law, as they historically had done. The RBerG also prevents newspapers and television from elucidating legal matters, thus limiting the possibilities of legal education. From the litigated cases relating to this statute, it can be seen that its function has been mainly to prevent activities on the borderline of the traditional lawyer's services, thus restricting the bar's innovativeness in extending its services into a new field. On the other hand, the law could not prevent new professional groups, such as tax counsellors and accountants, from expanding and taking away much of the economic counselling which contract lawyers traditionally offered among their services.

Not only the law regulating legal services survived. The amalgamation of a pluralistic infrastructure of legal aid institutions with the corporative version of the bar had a far-reaching impact as well: only the ÖRA in the city-state of Hamburg (and in the nearby city of Lübeck) and the public legal aid services in West Berlin are left as institutions offering general legal advice services. ${ }^{61}$

A renewed discussion on legal aid had not yet begun when, in 1969 , under the first social-liberal government, a major judicial reform ("Grosse Justizreform") was proposed. The discussions within the legal profession, however, did not recognize that an infrastructure offering different forms of legal counsel was necessary to cover the different demands for legal services. They saw the various issues of access to the law mainly in terms of the costs of lawyers and courts. Therefore, when at the "Deutsche Juristentag" (a leading, opinion-forming annual congress of jurists) the situation of "access to justice" was discussed - on an apparently international basis the topic was restricted to cost-subsidizing proposals. ${ }^{62}$ This had the effect, on the one hand, of the bar feeling protected from competition by non-private lawyer institutions, but, on the other hand, it avoided any attempt at developing appropriate forms of legal aid for

61 See note 11 supra.

62 See G. BAumgärtel, supra note 9; W. Grunsky \& N. Trocker, supra note 9. 
the socially deprived groups in society. The reform proposals which are now before parliament were formulated with an equally limited awareness.

IV. “Access to the Law" and the German Legal Culture

\section{A. Structural Restrictions to Innovativeness}

The fixation of the German bar on maintaining its monopoly on legal advice has to be seen in relation to its relatively weak position in the legal profession as a whole. This position can be demonstrated simply by comparing statistics concerning the German and American legal professions, which provide a clear indication of the differences between the legal cultures. Both countries have roughly the same number of legally trained people per capita of the population. However, in the United States, three fourths of all jurists are practicing lawyers. In Germany, the legal profession traditionally consisted of four groups about equal in size: judges, lawyers, civil servants, and private employees.

Every fifth member of the profession is a judge, and every fourth jurist works as a civil servant in the public administration. The number of jurists engaged by private companies had traditionally been as large as that of practicing lawyers. In recent years, however, admissions to the bar have risen, leading to fears that increasing competition might threaten the norms of conduct of practicing lawyers. It is a new phenomenon that practicing lawyers outnumber each of the three other groups; they now represent about one third of the legal profession. ${ }^{63}$

In spite of such recent changes, the German legal profession is still characterized by an almost equal distribution of jurists in the private and public sectors. Legal training is centered around the role of the judge, whose tenured career begins immediately upon termination of his legal studies.

The emphasis on the judge's role is reflected in some of the features of procedural law. German court procedures are dominated by

63 See D. Rueschemeyer, Lawyers and their Society: A Comparative Study of the Legal Profession in Germany and in the United States (Cambridge, Harvard University Press, 1973). 
the judge, who is more active than his counterpart in the American adversary system. In civil as well as in criminal courts, the German judge is obliged to fully investigate all the facts pertaining to the case. In his investigation, he does not rely upon the arguments presented either by the concerned parties or legal counsel, but prepares his cases, and especially the oral proceedings, upon the basis of welldocumented files and briefs. Observations of courtroom activity show a range of judicial behavior from authoritarian to patriarchal, but they rarely show a judge allowing the parties or legal counsel to dominate the course of the oral proceedings. ${ }^{64}$

The combination of these characteristics serves to explain why the American legal system has to look for more alternatives to litigation in court. The reasons are related to some deficiencies of the American court system which act as barriers to litigation. The great number of lawyers, their relative freedom to advertise their services (which has recently been upheld by the Supreme Court) and the possibilities of arranging for contingency fees - all these make the "input organization" of the litigation system very strong. On the other hand, the court's limited personnel leads to delays which act as a barrier to the filing of cases. Even though in Germany there are frequent complaints about delay in, and the cost of, court cases, the problem is not nearly so serious as in American courts. Thus, the pressure to look for alternatives to conflict resolution is much lower in Germany. Even among businessmen, settlements can be cheaper and more expedient if a judge in court is the mediator (with the possibility of a judicial decision). ${ }^{65}$ The dying away of the "Schiedsmann" institution demonstrates, as well, that there is no demand for extra-court alternatives in the German legal system (even if they are provided with legal status in the Code of Civil Procedure). ${ }^{66}$ The Schiedsmann was formerly quite active mainly for private criminal prosecutions and interpersonal conflicts concerning charges of insult, but he has lost most of his clientele with the de-

${ }^{64}$ See Blankenburg, Rogowski \& Schönholz, Phenomena of Legalization - Observations in a German Labour Court, in 2 European Yearbook in Law and Sociology (The Hague, Nijhoff, 1979).

$65 \mathrm{~K}$. Kohler, Die mOderne Praxis Des Schiedsgerichtswesens in Der Wirtschaft: ERgebnisse einer Untersuchung in Frankfurt/Main (Berlin, Duncker \& Humblot, 1967).

66 Bierbrauer, Falke \& Koch, Conflict and Its Settlement: An Interdisciplinary Study Concerning the Legal Basis, Function and Performance of the Institution of the Schiedsmann, in AcCess to Justice: Promising Institutions, supra note 8, at 39. 
cline of values which had formerly created a need for "keeping face" and defending one's honor by means of legal institutions. Alternative forms of conflict resolution are not considered as an urgent need in the German legal discussion, because German courts are successfully acting as a mediatory institution, where settlements can be reached with the help of a judge. In Germany settlements are generally worked out in court, with the judge acting as a mediator, while in the American legal setting bargaining prevails, much of this taking place outside of court.

There is a functional relation between the dominance of lawyers in the American legal profession and the fact that the scope of their activities extends beyond that of German lawyers. Some of the functions American lawyers have in registering real estate or building contracts are in Germany partly administrative, partly court responsibilities. German lawyers usually question witnesses in court only very shortly and after the judge has done so, and they rarely enter into extensive out-of-court investigations such as American lawyers do. Just as they are more passive in court sessions, so are they less active outside of the court in looking for cases and in organizing ways of presenting their clients' interests. The understanding of German lawyers is restricted more to handling legal matters; they do not provide all-round services for their clients as do some American lawyers. Again, we may argue that there is a relationship between the comparatively small number of lawyers in Germany, the limited authority given them by the Code of Civil Procedure and the restricted understanding which they have of their functions. These factors can explain why public interest lawyers and devices for bringing diffuse interest cases before the court, such as the American "class action," are unknown in German law.

These are some of the factors in German legal culture which explain why the legal profession there is less innovative in exploring new fields of legal action than in the United States. German legal culture still corresponds to the peace-under-the-law ideology much more than other Western legal cultures. It emphasizes the role of the judge rather than that of a partisan advocate. Procedural law makes it very difficult to organize diffuse interests. 


\section{B. A Possible Alternative: Integrating Legal Aid into Existing Institu- tions}

We have seen some reasons why the discussion on legal aid has not led to as much institutional innovation in Germany as in AngloAmerican countries. First, social antagonisms are less sharp in the Federal Republic of Germany than they are in countries with mass immigration and urban deterioration. This explains why in Germany there is no corresponding demand for legal aid institutions of the "first wave." Second, we have argued that the legal profession in Germany is much more integrated into state bureaucracies (including the very large judiciary), and that lawyers neither have the tradition of being adversary advocates for the public interest nor do they have the same range of legal devices as lawyers in the American legal culture. This explains why the "second wave" of improving access to the law has chosen different institutional channels than those mentioned in the access-to-justice discussion. This corresponds to the ideological tradition of German political culture to channel adversary interests into existing institutions rather than to establish counter-institutions such as an active advocacy bar. The use of legal strategies for contesting administrative decisions (as is done by public interest lawyers in the United States) would confront the German administration with political decisions they are not used to handling: German administrative law guarantees a maximum of accountability at the cost of minimizing political responsibility. ${ }^{67}$

While American agencies often have discretion in making lower level decisions, the German administration has traditionally been legally bound by a multitude of federal laws supplemented by executive guidelines issued by the states. These strict norms can be used to challenge administrative decisions in court, and there has recently been an increase in cases brought before administrative courts, most of which either deal with regulations restricting access to universities or concern town planning or construction permits. However, this increased use of courts is not initiated within the legal profession (as are, to a large degree, the "three waves" of "access" improvement). They are part (and 1970).

${ }^{67}$ F. Scharpf, Die politischen Kosten des Rechtsstaats (Tübingen, C. B. Mohr, 
only a secondary part) of a broader political movement. Extralegal movements have developed in recent years around issues such as town planning and nuclear power plants. They have largely used symbolic legal issues which are brought before the administrative courts. Local administrative decisions on such matters as construction permits, the control of anti-pollution requirements, and the observance of citizen participation rights in town planning can be contested only by individuals who have been affected by such decisions. Therefore, protest which is channeled into public interest law activities in the United States, is more likely to choose the arena of political parties and of political protest movements ("Bürgerinitiativen") in Germany, using courts only as secondary means in their strategy.

The increasing politization and the accompanying mobilization of administrative courts has produced some anticipatory reactions on the part of the administration as well as on the part of the legislature. Town planners as well as industrial investors have initiated campaigns of their own, thus opening up the possibility of early participation, by which they hope to make challenges at a later stage unnecessary. At the same time, administrators look for ways to avoid making decisions which would give rise to a conflict of interests. Attempts are being made to let legislative bodies on the local and regional levels decide on town planning and industrial investment, so that administrative courts cannot be invoked and the burden of legitimizing decisions will rest with the political parties. This can be seen as resulting from an administrative culture which is strictly bound to the law: the narrow range of administrative decisions renders the system incapable of decidin cases that involve politicized conflicts. Therefore, alternatives are being sought in the direction of participatory decision-making processes.

This we might consider to be the German contribution to the "third wave": integrating some of the functions of legal aid into existing institutions: the best known model for participation as an alternative to adversary conflict resolution might be seen in the German works' councils, which function as a preventive buffer in industrial conflicts. Recruitment as well as dismissal, changes of occupational status due to efficiency measures as well as changes in work rules, have to pass the works' council in the plant or firm. Even if these councils do not have a veto power, but only rights to information, such participation leads to the anticipation of protest 
and to early bargaining. When a decision is then taken, the works' council and also the trade union have been so involved in the conflict that they necessarily help to legitimize that decision.

Comparing labor conflicts in Germany with those of other countries reveals a high degree of conflict anticipation, which corresponds to the German notion of "legality" as a means of avoiding adversary conflicts. However, participatory conflict management rests on one precondition: that the collective interests in industrial disputes be well organized. Individuals can then leave the representation of their interests in the hands of functionaries, thus allowing them to develop patterns of oligarchical cooperation.

German history gives us reason to warn against trying to accommodate social antagonisms within a "peace-under-the-law" ideology. The fascists, however, did not seize power by means of corporative institutions, but rather by using party elections and parliamentary legitimation. Strengthening the adversary potential within institutions might, under the conditions found in German legal culture, lead to a functional equivalent to "access to justice" (such as legal aid in the Anglo-American countries). This, however, rests on two preconditions:

- some capacity must exist for organizing the interests to be represented (this is the case for labor conflicts, but apparently not for the interests of foreign workers or of housewives, to take but two examples out of many); and

- some autonomy must be pussessed by the internal adversary institution, which again is best provided by the backing of an external interest organization.

This puts the discussion of the legal profession into the framework of a theory of political organization. Where organizational capacity and conflict do not exist for socially weak groups, there is still the need for a strong legal profession to back legal aid and thus provide some organizational means for otherwise unrepresented groups. The whereabouts of such organizational needs and the ways in which they can be compensated for by the legal profession differ from one legal-political culture to another. 
PART FOUR

ACCESS TO THE LEGAL SYSTEM

AND THE

MODERN WELFARE STATE 



\title{
CLAIMS, DISPUTES, CONFLICTS \\ AND THE MODERN WELFARE STATE
}

\author{
by \\ LAWRENCE M. FRIEDMAN \\ Professor of Law, Stanford University
}

In this paper I will confine myself to a few general points about problems of access to justice in the welfare state. The subject is vast and complicated. Chiefly, I want to split the problem of access to justice into three types, which correspond to three different sorts of interest of the typical person in modern society. These are interests a person holds as a member of a group, as a person living in a community, and as a subject of a modern state. As a member of a group, a person may be part of a group conflict; as an individual living in a community, he may have a dispute with another member; and as a subject, he may have or assert a claim against the state or some large organization. The three types of interest give rise, I think, to different strategies for improving justice in society. My discussion will lead us to consider the role (or non-role) of formal courts, neighborhood courts, and other institutions in the access to justice movement. A lot, of course, will be left out; I can do no more than touch on a point or two on the subject.

The phrase "welfare state" is not very precise. It refers, more or less, to the type of country most of us live in: a liberal parliamentary state, committed to some degree of social engineering and economic planning. The phrase also describes one particular facet of these states: they have big, active governments, a corps of servants, and they administer fat codes of rules on labor, health, education, safety, and welfare. These states tax, spend, and regulate to keep their programs going; with one hand they control and extract, with the other they give out subsidies, benefits and pensions.

I will not spend time on a definition of "access to justice." The four volumes in six books edited by Professor Cappelletti et al. are rich in ideas and data. To capture the essence of access to justice, 
one could hardly do better than to quote a phrase from Cappelletti and Garth: "the means by which rights are made effective." 1 "Access," in brief, refers primarily to procedures ("means"); but the goal is substantive ("justice"). Our laws and constitutions express lofty - and often neglected - goals. How can we translate these into living, breathing reality?

\section{A Note ON History}

A movement to improve access to justice is distinctively modern. In reality, it does not go back more than a century or so. In most regards, as a movement it belongs to the most recent generation. The massive efforts which the six books of the project catalog do not have roots in the distant past. In saying this, I do not mean to deny the importance of 19th century efforts - the invention of legal aid, the right to free counsel, the reforms of legal procedure. But in essence, these reforms only tinkered with the system. This was not the fault of the earnest and dedicated people who struggled to make justice real. The topic simply did not sit very high on social agendas; and, from the modern standpoint, even the most passionate spokesmen did not grasp the problem very well.

Why did it take so long to discover the problems of unequal justice (as we see it)? One reason is that the problem itself, in one sense, is relatively recent. In saying this I do not mean to say that there was justice for all before the middle of the 19th century; quite the contrary. But, sociologically speaking, nothing is a problem that is not defined as a problem. ${ }^{2}$ The problem is new because the idea of equal justice is itself fairly new. Behind all the reforms and reform theories lies a single notion, which, in its day, was rather radical. It is the notion that the law is, or ought to be, a uniform, universal body of norms. Every person in society - every man, woman, and child,

${ }^{1}$ Cappelletti \& Garth, Access to Justice: The Worldwide Movement to Make Rights Effective: A General Report, in Access to Justice: A World Survey 6, 9 (Alphen aan den Rijn/Milan, Sijthoff and Noordhoff/Giuffrè, Vol. I of the Florence Access-to-Justice Project Series, M. Cappelletti \& B. Garth eds., 1978).

2 Of course, the relationship of poverty to justice is an old theme, but there were few organized attempts to solve it. On the pre-modern background, see Cappelletti, The Emergence of a Modern Theme, in M. Cappelletti, J. Gordley \& E. Johnson, Jr., Toward EQual Justice: A Comparative Study of Legal Aid in Modern Societies 6-16 (Milan/Dobbs Ferry, Giuffrè/Oceana, 1975). 
regardless of rank, social status, income, or occupation - shares equally in these norms, in the protection and the privileges that flow out of them. Law, in short, confers general rights (and extracts general duties).

The idea of a right is central to modern law. A right is a claim that must be granted. What is mine by right does not depend on the grace of a ruler or the discretion of a civil servant. Rights do not have to be earned, and they cannot be bought and sold. They belong to the citizen, inalienably. Whether "rights" have these qualities in the real world is another story. This is what rights are subjectively, and the notion is part of the mental baggage of modern woman and man. People learn about rights, and about equality of rights. When they believe what they learn, they come to expect a certain level of fulfillment. ${ }^{3}$

Most societies in human history have had no such notion of equality or of rights. Indeed, most societies took quite the opposite idea for granted. Most societies were frankly divided into classes, groups, orders, strata, castes, guilds, or the like. In these societies it was pretty well understood that duties, privileges, and rights, such as they were, depended on status - that is, they depended on the particular class, group, order, stratum, caste, guild or the like to which a person belonged. Birth determined much of a person's legal status. At birth, it might be once and for all decided where you stood in society - as man-child or woman-child, eldest son or middle daughter, hereditary tinker, pariah, or prince of the blood.

Moreover, law tended to be local, specific; law drew distinctions of culture, status, race, or religion. In the Ottoman Empire, to take one example, it made a great difference whether you were Moslem, Christian, or Jew. Each religious group lived by its own laws of marriage and divorce. Parts of this system survive to this day in the Middle East. Before modern times, the law was openly hierarchical; in many countries, it was a babel of local dialects; it recognized one law for the master, one law for the man, one law for the merchant, one law for the serf. Clearly, "access to justice," as we now understand it, is no problem (or at least not the same problem) in a caste-bound or hierarchical society, a society that accepts the idea that rank has its privileges. The Age of Reason (or at any rate the

3 See Friedman, The Idea of Right as a Social and Legal Concept, 27 Journal OF Social Issues 189 (1971). 
Industrial Revolution) brought a major change in basic theories of law. Older views came to be seen as irrational and unjust. The hallmarks of law in the new era were unity and uniformity of norms, inalienable rights, logic, rationality, conceptual purity and clarity. Modern times also produced the idea or ideal of the "rule of law," the "Rechtsstaat"; law must be systematic, universal, rational; its general rules should cover everyone, and every transaction, inside the nation-state. ${ }^{4}$ Out of this context grew the movement for access to justice. Without the idea of equal justice, there can be no struggle to attain it.

A second point about modern law - closely related to the first point - is that today more people than ever before take part in the official legal system, in one way or another, and whether they want to or not. In the past, most people in society stood outside formal law. This was true in medieval times, to a large degree. In an important sense, every society has a legal system, and law affects everybody in society, whether they know it or not, and even if the culture lacks anything remotely like our kind of courts, judges, lawyers, and the rest. It is universal to have norms and rules, and there is always some way of enforcing them. (In many simple societies, and in small face-to-face communities, what other people think - the pressure of opinion - exerts powerful pressure for enforcement of norms and rules. Sanctions are often highly informal in these societies, yet at times quite severe. In some societies it may be almost a sentence of death to be ostracized, banished, or "shunned.") But most societies have lacked our elaborate structure of courts, police, lawyers, judges and bureaucrats. ${ }^{5}$ The structure is a product of modern times, by and large. Simple societies had simple legal systems. Up to recently, too, the elaborate legal systems of the West operated directly only on that handful of people who owned land and formed the small upper class. The peasant was much less affected by formal official law.

Our own societies are vast, complex - and very demanding. People do not live in little clusters of villages. They do not grow their own food, build their own houses, weave their own clothes. They depend on distant strangers for the very air they breathe. The

${ }^{4}$ See generally Galanter, The Modernization of Law, in Modernization 153 (New York and London, Basic Books, M. Weiner ed., 1966); Friedman, On Legal Development, 24 Rutgers Law Review 11 (1969).

5 See Schwartz \& Miller, Legal Evolution and Societal Complexity, 70 American Journal of Sociology 159 (1964). 
official law is important in a way it never was in the past. People buy and sell houses; they make out wills; they write checks; they use credit cards. They marry and divorce by the rules. They carry driver's licenses, social security cards, identity cards. They are part of the official legal system not as a matter of preference or taste, but because they need to be and have to be. They have a stake in the economy, and a stake in the state.

Rich or poor, people need access to legality or justice, if only because they are all subject to the law. Most people in western countries belong to that great amorphous group, the middle class. They live in a money economy; they own at least a bit of property - a car, a television set, perhaps a bungalow. Their marriages are legal, mostly for social or religious reasons, but also because they want the legal consequences of marriage. When and if the marriage breaks up, they want a regular divorce because of its legal consequences. People in great masses not only use the legal system, it uses and controls them in their daily life. Who is so humble, or so great, as to be free from the grip of traffic rules? This part of the system of social control affects almost everyone. In general, the state manufactures thousands of rules and regulations; some of these are bound to affect the lives of every man, woman and child. Everyone has to pay taxes. In wartime, the state rations food, cigarettes, coffee, coal. Men have to serve in the army, like it or not. The subsidy side of the state also touches millions - through welfare and social insurance. Government pays benefits, and not only to the poor. At some point in life, almost everyone gets a government check. In some countries, babies earn family allowances for their parents at birth; and life ends with pensions for the old and gray. In between come food stamps, unemployment and disability payments, and many other kinds of benefit. All these put the citizen into direct or indirect contact with bureaucracy. The quest for social justice puts a burden on individual justice. The long arm of the law rests on the citizen's shoulder, every moment of his or her life.

\section{The Rule of Law and Its Enemies}

In the modern world, then, government is everywhere. The conditions of life give rise to two contradictory impulses, impulses pulling in opposite directions. On the one hand, there is the ideal of the rule of law or Rechtsstaat. Constitutions, bills of rights, and codes of 
law proclaim this ideal from the rooftops. Its priesthood is the independent judiciary. The judges, and their courts, guarantee through their vigilance a "government of laws, and not of men." In the courts, justice is the only king.

There are, to be sure, great variations from country to country in the way judges work, in the way they are chosen and trained. There is a great gap between (say) a French judge and an American judge. But there are also great similarities. For our purposes, the most striking and notable one is the judge's subservience to law. The judge, most emphatically, is not supposed to bend to the will of the state. He or she is not to decide cases in such a way as to advance the judge's career, or even to accord with the judge's sense of policy. In most western countries the judge is independent of the state to a considerable degree. The judge's freedom is no myth, but a working reality. This is because of the structure of the judicial system. Judges do not depend on the regime for appointment or promotion - at least in no obvious way. ${ }^{6}$

It would be naive, of course, to say that judges are always fearlessly impartial. On the whole, judges are middle-aged, conservative men. They come out of upper middle class backgrounds - or, if not, they adapt to the thoughts and habits of that class. The law they apply is not "neutral," and never can be. It presupposes and protects the social structure, which is riddled with inequalities. But when all is said and done, the judge does have some power to act without fear of personal consequence. If he decides against the state, this does not cost him his job, even though it is the state that makes out his paycheck. His reference group is not the state, but other judges, lawyers, the legal community in general. In some countries, of course, judges are bolder than in others. The United States is an extreme example. This is the very motherland of judicial review. Its judges have developed a body of rules (mostly procedural to be sure) which they impose willy-nilly on the government (with what actual effect we need not consider at the moment). Judges in other countries come out of different traditions. But judicial review seems to be gaining strength, and in unexpected places. ${ }^{7}$

6 In the United States, most judges are elected. But this has far less effect on the way judges behave than outsiders might suppose; and, in any event, many elections are uncontested.

The courts have been most obviously "activist" in the United States, though the role of courts in group conflict is growing rapidly elsewhere as well. We often hear that this role flies 
A strong, free body of judges, however, has definite drawbacks. The modern state may be committed, in theory, to the rule of law; it is also committed, in practice, to economic planning and social welfare. An independent judiciary bumps up against the felt need to carry out state plans. The welfare state, pushed on by its public, pursues policies of massive intervention. The state needs (or thinks it needs) strong central control. It needs to stamp out annoying, inefficient, niggling delays and oppositions. A panel of judges is no way to run a country. Neither are popular elections. At one time, perhaps, some tiny mountain canton in Switzerland could settle issues by a show of hands in the public square. For big modern states this is unthinkable. Government programs call for planning, continuity, forecasting, technical services of all sorts. Government must run its affairs like a business; the civil service has to get on with the job as smoothly as possible, punctuated only by an election now and then, which may (or may not) mean a change in policy, but which normally does not interfere with what civil servants do day by day. Of course, the state must bow to politics, pressure, and public opinion; in the long run, these mold the work of the state and its agencies (including judges). But in the short run, the modern state, despite its parliamentary forms, behaves like a group of small-scale, semi-feudal, temporary dictatorships.

This state of affairs is no historical accident. The welfare state is an administrative state; it became one partly out of necessity, partly in reaction to the failings of traditional government (judges included), which was cumbersome and inefficient. Legislatures were, or could be, more responsive to public opinion on a day-to-day basis. This was indeed one of the problems. The judiciary was less responsive; its problem was its inefficiency at governing. Moreover, the judges were trained only in "law," not in the arts and sciences needed to run a country. The independent judiciary looked like a relic of the past, a missing link. Its domain was shrinking, like some rare marsh bird as the swamps are drained. The formal court system thus lost power in the welfare state. First of all, new statutes and

in the face of tradition in civil law countries, in contrast to the tradition in the United States. True enough, but judicial review was at one time decidedly not the tradition in common law countries as well. The growth of worldwide judicial review is not the result of American influence. Rather, the conditions and social forces that produced judicial review in the United States appear to be present in some European countries, and will have much the same effect on judicial behavior. See generally M. Cappelletti, Judicial Review in the ContempoRARY WORLD (Indianapolis, Kansas City \& New York, Bobbs-Merrill, 1971). 
decrees of the government tended to be open and discretionary they delegated vast power to officials. Judges had no legal handle which they could grab in cases that challenged bureaucracy. Second, the state deliberately took business away from the courts and gave it to agencies, commissions, and tribunals, over which judges had little or no control. British judges, for example, remained proud and impressive in their wigs and robes; but they were steadily losing real power, like the queen in whose name they act.

Litigation had also become terribly expensive. No one decided, deliberately, to raise the price of law. This simply happened or evolved over the years. The reasons hardly matter. Access to the courts for relief against mistakes and injustices of the state became very, very costly. This meant the right to a day in court was almost meaningless for the ordinary citizen, and for all but the largest organizations. Quality, of course, is always expensive. A well-trained, professional body of judges costs money. Even though the government pays for some of the expenses (judges' salaries, courtroom overhead), still, professional judges move slowly, and what they have to offer is professional justice, legal justice, not lay justice, quick justice, kadi justice. The legal profession is now highly professional, as well. In the United States, standards of admission to the bar have tightened considerably over the last hundred years. Good lawyers have become extremely expensive. They are beyond the reach of ordinary people. In any event, the big money is in business law; and that is where the lawyers gravitate. In other countries the situation is basically the same. The English barrister is perhaps the extreme case: the common mortal cannot even approach his throne without an intermediary. ${ }^{8}$

As was said above, nobody planned these developments; but they happened all the same. Justice became out of reach for the ordinary citizen. As far as judges and lawyers are concerned, out of sight was out of mind. The main interest of lawyers was (and had to be) making a living; representing the poor was no way to bring in the dollars. To be sure, there were always men and women of conscience in

8 On the British profession, see M. Zander, Lawyers and the Public Interest (London, Weidenfeld \& Nicolson, 1968); on the American legal profession, see L. Friedman, A History of American Law 525-66 (New York, Simon and Schuster, 1973); J. Auerbach, Unequal Justice: Lawyers and Social Change in America (New York, Oxford University Press, 1976); see the rather bitter remarks about the German legal profession in Rasehorn, Aussergerichtliche Rechtsberatung in einen "schwierigen Vaterland," in RechtsBERATUNG ALS Lebenshilfe 17-19 (Neuwied, Luchterhand, T. Rasehorn ed., 1979). 
the profession. For a century or so, the organized bar has concerned itself, too, with law reform. Still, the movement for access to justice would get nowhere if it had to depend on the organized bar. The profession is interested mainly in craft or professional problems. In common law countries, lawyers get their ideas of what is wrong from reading reported cases, which do not reflect the failings of access to justice. In civil law countries, jurists flail away at "problems" of technical disorder.

In short: in the modern state, there was an independent judiciary and a legal profession with some commitment to reform. But neither of these interfered basically with administrative freedom. And ordinary citizens had rather poor access to courts. There was some attempt to provide lawyers for the poor in criminal cases; some attempts - usually inadequate - to provide general legal aid to the poor. The rest had to wait for the rise of a movement.

\section{Group INTERESTS 9}

\section{A. The Importance of Organization}

The independent judiciary did have one vital function. It provided a forum for very intense, powerful interests. Those with time, money and will could use the courts for redressing grievances. It was, in short, the institution to which group interests had access, interests which were the basis of a movement.

As a movement, access to justice itself implies organization. We hear a good deal about the legal problems of diffuse groups. Ironically, a diffuse group is not legally important until it loses some of its diffuseness - until it has spokesmen, organization, structures. An interest group which is truly diffuse is too paralyzed and weak to express itself, let alone enforce its rights. Take, for example, the "interest" of the overweight, or ugly. Employers (among others) are prejudiced against them. If two people with the same qualifications ask for a job, firms will tend to hire the good-looking applicant over the fat or ugly one. There is - up to now - no movement to redress

9 See generally J. Handler, Social Movements and the Legal System: a Theory of Law Reform and Social Change (New York, San Francisco \& London, Academic Press, 1978). 
the grievances of what we might call the body minorities. This group is truly diffuse (and likely to stay that way). As long as this is true, no "rights" will be won, no share in the movement for access to justice. Interests that have pushed themselves onto the stage have been organized, have been part of a movement, have, in short, been groups; or they have had active spokesmen who "adopted" them (as happened to the whales and the caribou). Groups did not gain ground because the legal profession "discovered" them, or because reformers in and out of government took up their case on theoretical or moral grounds. They gained ground by exerting pressure. It was the squeaky wheel that got the oil.

Let us look at a case in which the United States Supreme Court vindicated rights of a suppressed, diffuse minority. In Papachristou $v$. City of Jacksonville (1972), ${ }^{10}$ defendants challenged an ordinance of Jacksonville, Florida. The ordinance lumped together as "vagrants" the following: "rogues and vagabonds... common gamblers... common drunkards, common nightwalkers, thieves... lewd, wanton, and lascivious persons... persons wandering or strolling about from place to place without any lawful purpose or object, habitual loafers... persons able to work but habitually living upon the earnings of their wives or minor children." The defendants were arrested on such charges as "prowling by auto" or "loitering"; or were labeled "common thieves" or "vagabonds." 11 The "rule of law," said Justice Douglas, writing for the court, demanded "equality and justice." Vagrancy laws were "useful to the police" - they made it "easy to round up so-called undesirables." But the ordinance gave the police too much power. What excuse could there be to arrest people walking or loafing or loitering or strolling, who merely looked "suspicious" to the police? The ordinance was so vague it did not give fair notice to the public; it did not explain in simple terms what was right or wrong conduct. As a result, the ordinance was "plainly unconstitutional."

Plainly unconstitutional perhaps; but the ordinance had had a long, long life. No doubt it was used as a net for undesirables. In every western nation, not least the United States, police enforce norms of respectability, discipline and order against the poor and the

10405 U. S. 156 (1972).

11 Defendant Papachristou, a white woman, was perhaps arrested because she was riding in a car with a black man. 
unpopular, under the umbrella of vague language (or no language at all). Yet the Papachristou case was decided only yesterday - in 1972. It was more than a century and a half after the Bill of Rights, more than 100 years after the 14 th amendment to the Constitution, that this kind of ordinance was tested against constitutional standards. This long span of time speaks volumes about how law responds to those who are genuinely poor and unorganized. Not until the rightsconsciousness of the 1970's, not until the flowering of civil liberties organizations, not until racial and cultural underclasses grew militant, did the Papachristou case reach the threshold of legal consciousness.

Yet all this time courts were symbols of a national commitment to the basic rights of man. They served an important ideological function. One could always point to the judges as living proof that there was a way to right injustice in society. Of course, since the courts were stiff, remote, formal and expensive, and since the state had given itself immunity from attack, on the whole the symbolism was misleading, the ideology deceptive. High costs of litigation, one might add, also made private organizations (big business) fairly safe from customer grievances. The little man had no forum. Even the small claims courts, which were supposed to help him solve his problems, did the opposite: they gave doctors, grocers, and merchants cheap and efficient ways to collect their customer's debts. ${ }^{12}$

\section{B. Judicial Review: Some Pros and Cons}

The court system is passive. Judges do not invent cases - they wait for them. Without movements, the big cases do not come. Courts have other drawbacks. They hand down authoritative rulings; but usually they have no way to follow them up, no way to enforce their mandates, no way to tell if anyone except the immediate parties listens or obeys. Sometimes the courts hand down decisions that seem to vindicate important rights, but in the real world nothing

12 See Yngvesson \& Hennessey, Small Claims, Complex Disputes: A Review of the Small Claims Literature, 9 LAw AND Society Review 219 (1975). On modern reforms, see, for example, Taylor, Special Procedures Governing Small Claims in Australia, in AcCess to Justice: Promising Institutions 595 (Alphen aan den Rijn/Milan, Sijthoff and Noordhoff/Giuffrè, Vol. II of the Florence Access-to-Justice Project Series, M. Cappelletti \& J. Weisner eds., 1978/1979); Applebey, Small Claims in England and Wales, in id. at 683. 
actually happens. One example will do. In Bailey v. Alabama (1911), ${ }^{13}$ the Supreme Court confronted an Alabama law punishing farm workers who acted "fraudulently." A worker who signed a contract, took a money advance, and then quit his job, broke the law if he had intended all along to "injure or defraud" his employer. The very act of quitting work was prima facie evidence of this fraudulent intent. ${ }^{14}$ The point of the statute was plain. Once a black farm worker signed on, at the start of the growing season, he was bound to his employer. It was the custom to give a small advance. If a worker then quit, he could be arrested and charged with fraud. He faced a fine, which he could not pay. The choice was then to go back to his employer and work off his fine - or serve in the dreaded chain gang.

The case was brought on behalf of Lonzo Bailey, a black farm worker, who had signed on with a landowner, the Riverside Company, in 1907 . Bailey's pay was $\$ 12$ a month; the company gave him an advance of $\$ 15$. In February, Bailey quit. He was arrested and convicted under the statute. A group of Alabama Progressives financed an appeal. The Alabama Supreme Court affirmed Bailey's conviction. The United States Supreme Court disagreed, struck down the Alabama law, and set Bailey free.

The case was hailed as a tremendous victory - a "marked step forward in the battle against peonage." But in practice, little or nothing happened. Alabama tinkered with the wording of its statute. Other Southern states ignored the decision, or found ways around it. ${ }^{15}$ Black laborers toiled on, tied as before to their masters.

Why did Bailey fail? It was ahead of its time. No organization state, federal or private - had the will and the strength to follow through. To make an impact, some group had to monitor conditions of labor in the South, bring more cases, struggle against poverty, ignorance, prejudice, and injustice. Victims of the Alabama system had no real day to day access to justice; all doors were closed to them, even though the highest court of the land had rebuked the state, and vindicated basic rights. Bailey was bold, noble - and hollow. In the

13219 U. S. 219 (1911).

14 The worker, according to the law, was not to testify about "uncommunicated motives, purpose or intention." In other words, he could not deny he intended to cheat his boss.

15 See D. Novak, The Wheel of Servitude: Black Forced Labor after Slavery 56-74 (Lexington, University Press of Kentucky, 1978); Cohen, Negro Involuntary Servitude in the South, 1865-1940: A Preliminary Analysis, 42 Journal of Southern History 31 (1976). 
textbooks, it could be cited to show the beauty and ethical force of judicial review. Legal scholarship, of course, rarely goes beyond printed texts. What went on in the cotton fields was not the concern of the jurists. Bailey v. Alabama was pure symbol, pure mirage.

Bailey is now more than 60 years old. There have been enormous changes in race relations since it was decided. The Supreme Court, many state courts, and the lower federal courts, have struck many more blows for racial equality. Starting with Shelley $v$. Kraemer (1948) ${ }^{16}$ and Brown v. Board of Education (1954), ${ }^{17}$ the cases have not been ineffective. They have touched off controversy, opposition, even riots and bloodshed, but not the silence and apathy that followed Bailey v. Alabama. Why the difference? Today, organized groups with passion and political power are carrying on the battle for civil rights; and the government, too, has made a commitment to the cause. The key factor has been the movement: this, and only this, broke through the indifference of government. At a certain point, the movement touched off a chain reaction. By now, it has reached into every corner of American life, and it has reverberated at every level of government, and in the private sector. Not always with perfect results, by any means; but race relations have been fundamentally altered. The lesson is that courts can make a powerful contribution to social justice - but only when strong forces outside in society push cases forward, and follow up their results.

Formal litigation, then, does best for group interests. The cases often pose complicated, delicate problems; they are hard to manage and expensive; they may have tremendous social consequences. There are, of course, all sorts of reasons why it is poor policy to let judges decide these so-called "extended impact" cases - cases with effects that ripple out all over society. Why should a judge have the last word on where a new airport should be built, or whether it should be built at all, or whether mental hospitals are decent enough to meet constitutional standards, or whether people should be put to death for murder, or women should be free to get abortions, or whether some grove of old trees should be chopped down? ${ }^{18}$ In theory, normal democratic processes will handle these problems: let the voters decide. But, first of all, we shy away from majority rule on

16334 U.S. 1 (1948)

17347 U. S. 483 (1954).

18 For a criticism of the role of courts in "extended impact" cases, see D. Horowitz, The Courts and Social Policy (Washington, Brookings Institution, 1977). 
some issues of morality and social justice. Second, no country is so democratic, so fine-tuned politically, that it is totally free of bias, corruption, or inefficiency. Third, it is not really the voters, in most cases, that would decide, but a civil service, living and working in tight, sealed-off compartments, and fairly unresponsive to citizen pressure. In a perfect world, there would be no need for judicial review. Nobody lives in a perfect world.

Judicial review is far from ideal, even for group interests. Its very power is one of its disadvantages. Like the atom bomb, it is almost useless for minor skirmishes. It is not a bad weapon against bureaucracy. It is also a useful way to scoop up diffuse interests and concentrate them where they have the most impact. Environmental groups, for example, have done well in the courts. (They have also had some success with the legislature.) But courts refuse (probably rightly) to go over issues that agencies have already decided. So the questions argued in, say, environmental cases are not the real issues; they are phony issues, procedural issues, technical issues. ${ }^{19} \mathrm{~A}$ new jetport is proposed - and opposed. The people fighting it are afraid it will make noise, or ruin the value of their property; others are angry because a vital marsh may have to be drained. By the time the case reaches court, these "issues" will not be discussed. The opposition group lost its policy fight inside the responsible agency. Findings of fact went against them. The case in court will turn on some vague or obscure section of the law, on some point of procedure, on some claim that the agency did not use proper form, or did not run hearings in exactly the way called for by law. Issues of stupendous importance will turn (or appear to turn) on the pivot of a tiny point of practice. And the litigation, win or lose, will hinder and delay the legitimate business of government.

These real drawbacks of judicial review feed the prejudices of people who do not like what courts have been doing. In an age of activist courts, many of the critics are conservatives who feel courts are too liberal, or too irresponsible. Some worry out loud that the courts are not "neutral" enough, that they are losing their legitimacy. There is certainly much to grumble about. But what courts have done in some societies, no other institution did or could do; and, in any event, as we saw, the push came from outside. The

19 See, for example, Calvert Cliffs' Coordinating Committee, Inc. v. U.S. Atomic Energy Commission, 449 F.2d 1109 (1971). 
courts did not invent the demand for justice. At best, they responded.

\section{The Litigation Explosion}

I would like to add a few words about one specific complaint. In the United States, the right to free counsel and an outbreak of claims-conciousness, we are told, have brought about an "explosion" of lawsuits. The courts are hopelessly clogged. Everybody is suing everybody else. Litigation rates are skyrocketing.

Yet there is precious little evidence to support the claim that litigation rates are going up. Quite the opposite may be true. The first careful modern study of litigation rates was carried out by José Juan Toharia, covering Spain between 1900 and 1970. ${ }^{20}$ Toharia found an inverse relationship between litigation rates and economic development: it was in urban centers (Madrid, Barcelona) that litigation rates per 1,000 population were most static and stable. Research in other countries has confirmed his findings. It is hard to tell whether the Toharia thesis applies to the United States. The statistics are poor, and there are serious problems in counting cases. But there is certainly no proof of an "explosion" in the rate. ${ }^{21}$ To be sure, the work load of federal courts has increased considerably in recent years. But federal cases are only a small fraction of total litigation. We still have no good notion of trends in state courts.

In any event, litigation is not easy to measure. What are we to do with (say) uncontested divorces? There are perhaps a million or more of these a year in the United States. They are filed, numbered, and reported statistically as "cases"; typically, the court does nothing but rubber-stamp what the parties and their lawyers have decided. Do we mean contested cases only, cases that go on trial? And are these increasing? We simply do not know. Perhaps there are more "extended impact" cases than before. Perhaps what strains the capacity of courts are not sheer numbers, but a few big cases with monster appetites for judicial energy and time. Some of these

20 J. Toharia, Cambio social y vida Jurídica en España, 1900-1970 (Madrid, Editorial Cuadernos para el Diálogo, 1974).

21 See Friedman \& Percival, A Tale of Two Courts: Litigation in Alameda and San Benito Counties, 10 Law AND Society Review 267, 291-92 (1976). 
are group action cases. Do they monopolize the business of courts, driving out ordinary cases? But "ordinary cases" were never in the courts; to this extent, Toharia's point is certainly right.

Some kinds of cases have surely become more common - prisoners' petitions, medical malpractice. If you give people fresh rights, and pay for a lawyer to help them, of course these rights will be used more than before. Some claims will be groundless, or absurd. The courts have a hard job screening the wheat from the chaff. But, typically, they also have larger and better staffs than ever before.

Critics of the courts must also explain why rising rates are not grounds for celebration, not lamentation, if the rates mean access for the underprivileged. Society does not run courts for the convenience of judges. In modern societies the cost of the judicial branch is trivial compared to the total budget. Nobody would notice any fiscal difference if the system were expanded even to ten times its present size. A new bomber fleet, or a highway network, costs more than all the judges in the world, placed end to end.

\section{INDIVIDUAL INTERESTS}

So far, we have emphasized the courts, and their role in vindicating group interests. But, besides group interests, people have individual interests - relationships with friends, neighbors, family. These too can give rise to disputes. People also have what we call subject interests - interests as citizens of the state, as taxpayers, as users of law. They also commonly have relationships with large private organizations - businesses, mostly. For many purposes, complaints against these resemble complaints against the state. In both cases, the little man or woman confronts a big and distant bureaucracy.

Courts serve individual interests poorly; they are too expensive, and they speak in the language of law, which people do not understand. This problem has recently attracted much scholarly attention. We hear about the need to find ways to redress grievances, ways to participate, to make justice readily available, and to combat despair and anomie in modern life.

Nobody could (or should) disagree. But I want to put in a word 
or two of caution. Life in our huge, bloated metropolitan areas is not like life in small tribal communities, or medieval villages. Thousands of isolated, rootless people live in our big cities. It is not easy to help these people. They have "rights" on paper, and we can give them more. But what use do they make of these? Studies show that people who most need the rights we give out are not the ones most likely to use them, or use them well. ${ }^{22}$ Skill and experience pay off in every human endeavor, and taking rights seriously is one of these.

Let us put these people to one side and look at the rest of modern society. Most people are not rootless and isolated. But their roots and ties are not like those of people who live in tiny communities. People in Western Europe, North America, and in other countries (Australia, Israel, Japan) do not live in "communities" at all. They belong to groups, but most of these are not face-to-face groups. A group is not a community, in fundamental ways. In the village, life centered around family and neighbors, the so-called "primary group." This is not the way of life in a housing development or subdivision.

Let us take as an example a typical family (husband, wife, two children) in a big city apartment. The father works in a factory or office; his wife probably works too, at least part time. The family has many social connections; but for the most part, these are not centered on people who live in their building. They are probably friendly with some neighbors, while others are total strangers. Some relatives live in another neighborhood, some in another city. The family has work relationships, but these may (or may not) be quite casual. The children have school friends. The family may belong to a church, a club, a political party. They are customers at various stores; in some, they know the clerk or owner's name; in others, they are strangers. They buy goods and services; they use doctors and dentists; they also have contact from time to time with civil servants - teachers, clerks, policemen.

These relationships are social, economic, political. Some are casual; some are deep. The family may identify with people they have never met - people in the same organization, with the same interests, or members of the same religion, group, region, or tribe. Some of these relationships cross great distances; these relationships

22 See, for example, Steele, Fraud, Dispute and the Consumer: Responding to Consumer Complaints, 123 University of Pennsylvania Law Review 1107, $1123-26$ (1975). 
are more specific, and more specialized, than relationships in a village community. Relationships may be smooth or troubled; potentially, they can lead to conflicts, problems, difficulties, disputes.

How shall we settle these various individual conflicts, problems, disputes? As we said, many people feel that society is not doing a good job in handling these matters. The courts are unsuitable. People have no place to go to get justice. Problems are mishandled (or ignored); this leads to unfairness and frustration. One remedy, often suggested, is to press for neighborhood courts. Some societies have experimented with this kind of justice. ${ }^{23} \mathrm{I}$, for one, am somewhat skeptical about lay justice, people's justice, and the idea - a bit romantic, perhaps - of resurrecting local or neighborhood courts in our cities. For ideological reasons, socialist countries find the idea of people's courts quite attractive. The liberal democracies are more suspicious of such schemes. They have some reason. By and large, as we said, people do not live in communities. Hence, it is not easy to pinpoint individual interests in space. It might be worthwhile to set up some sort of "court" for disputes among neighbors in a huge housing development. The same might be true for frictions and aggravations in the factory. But millions of people live in small houses, or small apartments, and do not work in big factories. Even for those who do, a local "court" could deal with only a few of the many problems or disputes that come up in life. It may be a tragedy that "community" in the traditional sense has largely passed away. But the old social system is a smashed egg; we cannot put it together again.

Besides, a "people's court" may offend our ideas of autonomy and privacy. Take our imaginary family, in their apartment. Suppose their neighbor plays music, very loud, very late. They talk to him; he refuses to change his ways. What can the family do? There is no easy answer. Of course, they can move out. Or they can try to harass the neighbor, driving him out. These, of course, are poor solutions. Can they take him to court? That would be much too expensive. Only the very angry, spiteful - or rich - would try this. Complaints to the

23 See Kurczewski \& Frieske, The Social Conciliatory Commissions in Poland: A Case Study of Nonauthoritative and Conciliatory Dispute Resolution as an Approach to Access to Justice, in Access to Justice: Promising Institutions, supra note 12, at 153; Weiss, The East German Social Courts: Development and Comparison with China, 20 American Journal of Comparative Law 266 (1972). 
landlord? Yes, but the landlord may not be responsive. Would we be better off with a cheap, neighborhood court, open night and day? It seems so. We could drag the noisy neighbor to this court, tell our story, and let justice be done.

The picture is very appealing - if we are right, and the neighbor is wrong. But it is possible that we are unreasonable, not our neighbor. The lack of a "court" protects him. As things now stand, we have to put up with each other. Each of us is immune from legal attack. A quarrelsome, vindictive, or unbalanced neighbor can do very little about our behavior - which is fine since (let us assume) his complaints are quite groundless. In the present state of affairs, neither of us can do much to the other. We have to "lump it," in William Felstiner's phrase. ${ }^{24}$ There is no "people's court," no neighborhood tribunal. We are in a situation of reciprocal immunities.

Nobody could say this is ideal. It allows injustice, or at least great inconvenience. Should we, then, make a forum for this kind of dispute? Perhaps. But free access would destroy the reciprocal rights of privacy, the zone of immunity which protects us in our way and style of life, our whims and quirks, in a word, guarantees our personal freedom. A "people's court" is quite likely to oppress the deviant, the slightly odd, the dissenter, the unpopular modes of behavior. Freedom of lifestyle is a precious gift. It is a value that knows no income or class. The rich can buy more of it than the poor; but as far as we can tell, like health and happiness, everybody wants a share.

These comments apply, of course, to individual disputes where the parties are, more or less, social equals. The problem is acute because the domain of "community" is shrinking. Where community still exists, what is needed is a forum for settling disputes inside the community - family courts, mediators, counseling services. But some disputes are best "solved" by letting people alone - free to change jobs, apartments or cities, if they must. Poor as this is, there is no better solution, for now.

${ }^{24}$ Felstiner, Influences of Social Organization on Dispute Processing, 9 LAw AND S SocieTY REview 63 (1974). 


\section{Subject INTERESTS}

In our everyday affairs, greater access to courts is not what most of us need. Courts can serve our group interests, and often do. But this is not enough. Nor are our main interests individual interests, which a "people's court" might serve. Justice for the ordinary citizen has quite a different agenda. In the modern welfare state, most citizen complaints reflect subject interests. They are complaints against large organizations, including the state. They are complaints against a policeman, a municipal officer, a pension or welfare bureau, or the Department of Motor Vehicles. They are complaints about garbage collection, military service, taxes or schools. Or they may be complaints against a department store, for selling a defective television set, or against a dentist who overcharged, or a landlord who neglected to make repairs. There might be a problem with the telephone company, the gas company, or with railroads and airlines. These are private companies in the United States; in many countries, they are owned by the state. It hardly matters which. The examples suggest that most (though not all) problems of access arise out of situations in which the ordinary citizen faces a large organization. The organization - state or private - may be malicious or corrupt; more likely, it is simply rule-bound and inflexible, or slow, torpid, and unfeeling. The citizen's claim is not always justified, of course. It may come up out of ignorance or misunderstanding; it may even be absurd. Justice does not mean giving in; it means taking claims seriously.

Over the last century, the trend has sometimes gone in the opposite direction. The state has been anxious to insulate itself from the nuisance and bother of public complaints. Large organizations have felt a similar urge. Rules of administrative discretion shield government. Contracts of adhesion, waiver clauses, and the like, shield private businesses.

What is needed are efficient, just, and humane ways to break through these barriers. Citizen Advice Bureaus, ombudsmen, reformed small claims courts - these are examples; there are surely others. A slow and insensitive bureaucracy is an annoyance to everyone, but to a person on the edge of hunger, a delayed or withheld check can be tragedy. People in modern society depend on big companies and big government for heat, light, and water, sometimes 
even for shelter, food, and air. The job is to make claims and complaints against the giant aggregates easier, cheaper, and more just. Yet this must be done in such a way as not to ruin what there is of efficiency and rationality in government. ${ }^{25}$ This is the great, and necessary, goal of law reform in the coming years.

25 To a certain extent, it is inevitable that improving access to justice will make the operations of government more expensive. It is more efficient to be able to do as one pleases, compared to a situation where one is accountable to somebody or some other agency. Since it does cost something for an agency to become responsive, the costs of doing justice should be built into an agency's budget from the outset. But it is possible, no doubt, to look for ways to minimize the costs and maximize the benefits. At least one hopes so. 



\section{ACCESS TO THE LEGAL SYSTEM \\ AND THE}

MODERN WELFARE STATE:

\section{AMERICAN CONTINUITIES}

by

MARTIN SHAPIRO

Professor of Law, University of California, Berkeley

\section{INTRODUCTION}

As in so many other areas of legal development, the American experience with access to justice has been in large part shaped by constitutional theory and litigation. The Bill of Rights provides for "due process" of law and guarantees the right to counsel. The U.S. Constitution also provides for that most fundamental common law guarantee of access to the courts, the writ of habeas corpus. As one would expect from an eighteenth century document whose rights provisions are drawn largely from English liberal sources, these rights are essentially negative. They are rights against government which come into play essentially in reaction to government initiatives. While the Fifth Amendment provides that property as well as life and liberty may not be taken without due process of law, and so opens the door on the civil side, the Constitution is basically concerned with rights under criminal law. In this sense access to justice takes on a particular coloration. It means in effect that the government may not punish individuals except through the regular procedures of the criminal courts. The American Constitution preserves the English view that the courts would serve as a haven against government oppression. Habeas corpus was crucial because it insured that one unlawfully held by the government could get himself before a magistrate and invoke the judicial mechanisms of justice.

Because the context is that of criminal law, we must remember that American rights are fundamentally involved not with access to, but escape from, justice. The individual was not really seeking access to a government service - namely the justice service. Instead, he was desperately seeking to escape from the hands of government back into the purely private sector and invoking judicial processes to do so. 
This essentially negative caste to American Constitutional provisions would not have been so pronounced if constitutional government had not worked so well. For if the American state and national governments had frequently seized the bodies of men by purely executive action, then those men would have desperately clamored for access to the courts and seen judicial services as a highly positive intervention against the coercive powers of government. Instead, with rare exceptions - and most of those clustered in that unique breakdown of American constitutional government, the Civil War American governments seized men's bodies through the regular processes of criminal justice. The secret police did not remove the citizen from his home and cast him into dungeons or labor camps. Instead, state prosecutors brought an indictment, and defendants were arraigned and tried in trial courts.

In this context it was the state that brought the individual into court. Far from seeking access to the court, the criminal defendant was trying to get out of it. In short, in the American context the problem of access to justice was not seen primarily in terms of breaking down the barriers that prevented the citizen from reaching the courts, but, instead, of erecting barriers that would keep the criminal justice system including the courts from reaching him.

It is for these reasons, as well as a number of others, that access to justice in the United States has been seen primarily in terms of right to counsel. And the formulation of the problem as one of right to counsel has, in turn, a number of peculiar consequences, for it focuses questions of access not on access to government instruments - namely courts - but on access to private, professional services, the services of attorneys. One may, of course, explain this shift of focus from the public official called judge to the private practitioner in a number of ways. There is the peculiarly pervasive influence of lawyers on American politics that had been noted as early as de Tocqueville. There is the constitutional fact of the concreteness of the right to counsel clause as opposed to the vagueness of the due process clause. There is the historical fact that the mother country was just then itself finally resolving the question of whether criminal defendants were entitled to counsel, so that the question loomed particularly large in the eyes of the colonists.

Resort to such a range of explanations, however, ignores the most salient fact. That fact is that since the founding of the republic, Americans have had considerable confidence that relatively indepen- 
dent and impartial courts basically oriented to the rights of individuals would be readily available to the average citizen. If this were true, then there was no problem of access to justice in terms of access to fair judges, and so attention might well turn to more peripheral questions such as counsel.

\section{Historical Perspective of American Access to Justice}

\section{A. The Frontier}

American confidence in their judicial institutions was no doubt overdone, but it reflects actual historical developments that are extremely important in setting the American access to justice scene. First of all, it must be remembered that American attitudes toward courts were shaped more by the frontier than by the colonial experience. Of course, even the judges of the original colonies and the 13 original states of the Eastern Seaboard did not constitute a learned and essentially closed caste of the continental kind. Nor did they approach in levels of education and social distinction the English judges of their day. Even in New York and Virginia the social distance between the average citizen and the high court judge was not nearly as great as it was in any European country. Nonetheless, the judge who sat within sight of the Atlantic might have made some claim to the social and scholarly pretenses of his European counterpart.

The American judicial experience was, however, inextricably intertwined with the vast task of continental nation-building. The United States began with 13 court systems, some of them rudimentary. It has ended with 51 . Thus, Americans have had to build from nothing 38 complete court systems, each with its own trial and appellate courts and its own complete system of jurisprudence. In this sense American legal history is a long and highly successful story of building access to justice. In the new states that stretched from the Appalachian Mountains to the Pacific, judicial services were among the first government services introduced. Territorial courts typically were in operation even before military security had been completely assured. Each new state had its own constitution which invariably provided for a supreme court, usually sitting at the capital. Typically, some sort of local justice of the peace jurisdiction was established. The principal trial courts might initially consist of circuit-riding 
judges, but within a relatively short time a major trial court would be established in each county.

The county is the basic territorial subdivision of the American . state. With many exceptions in the very large Western states where a single county may include hundreds of miles of mountains and desert, most Americans could reach their county "seats" within a half-day's ride by horse and buggy. Until post-World War II expansion obscured the traditional face of American towns, one could be sure to find the County Court House at the center of every American county seat. It was often the largest building in town. And, most significantly, it was typically the center of all governmental activity in the county. The very center of local government was called the "Court House" precisely because judicial services were typically the first local government services established, and all subsequent services clustered around them. Indeed, in parts of the Midwest many such "supplementary" services as road maintenance are still under the supervision of elected government officials still nominally called judges.

A number of characteristics of these new court systems in addition to their geographic dispersion are of interest in connection with access to justice problems. First, in the new states even more than in the old, the social distance between judges and litigants was relatively slight. Although the state constitutions did not require that judges be lawyers, in fact most of them were. But law did not become a learned profession until the twentieth century in the United States. Particularly in the new states, legal training consisted of a scanty apprenticeship under a lawyer who himself knew little formal law. Later, as formal legal education became the more normal route to the bar, state universities admitted a much wider range and higher proportion of students than their European counterparts. While the bar showed a strong middle class bias, it nonetheless contained persons of very diverse backgrounds, including many sons of farmers or men who themselves farmed. Judges were chosen from the practicing bar, and usually from among those lawyers who had been active in politics. Thus, judges were far less of an isolated, elite caste than they were in Europe. Typically, they were men who had spent many years practicing law in small towns and medium-sized cities. And their private practice almost invariably consisted not of purely legal activities but of the mix of law and entrepreneurship that marks the American lawyer whose clients are basically small businessmen and 
farmers with substantial land holdings. Moreover, these same lawyers were deeply involved in electoral politics. The stump speech was as normal an activity for such lawyers as an address to the bench. And the jury system meant that the lawyer spoke to the people not only at election time, but also in the daily practice of his profession.

For those who read Abraham Lincoln's descriptions of his life as an Illinois lawyer, riding on horseback from county seat to county seat with the circuit judge and other lawyers, their Blackstone's in their saddle bags, it becomes clear that in nineteenth century rural America, access to justice had a far different color and feel than it did in nineteenth century Europe. Those seeking justice were essentially yeomen farmers and small merchants. To be sure, as laymen they viewed the law as a mystery. But the lawyers and judges they confronted were men little different from themselves, and the juries no different at all. In such a situation, the principal problem of access to justice was not that of breaking down the barriers between the common people and the courts, but simply of pushing enough courts far enough out into the countryside to be physically available to a widely dispersed rural population. It was on this task that Americans spent most of their judicial energies.

This picture is in a sense excessively idealistic. Clearly, nineteenth century American substantive law was bourgeois law designed to serve the property-owning classes and redesigned to serve the capitalist entrepreneur. ${ }^{1}$ Clearly, there were many persons too poor to retain the lawyers who would have given them access to the justice system. And, clearly, the slaves and then the former slaves were denied access to that system. Nonetheless, for that relatively large share of Americans who owned their own farms or small businesses, courts were close by and closely woven into the life of the community.

\section{B. Urban America}

The situation in urban America, and particularly for the vast numbers of continental immigrants who lived in urban America, was quite different. There were plenty of courts close at hand. But they were courts that applied an unfamiliar law by unfamiliar procedures

1 See M. Horwitz, The Transformation of American Law, 1780-1860 (Cambridge, Harvard University Press, 1977). 
in an unfamiliar language. For these urban immigrants, access to justice came along a number of routes, some of which have their European counterparts and some of which appear to be uniquely American. First of all, as in the new states, the physical problems had to be met. This became essentially a problem of municipal finance. There had to be more court houses and more judges as the cities grew rapidly under the flood of immigration.

More important was expansion of the bar. Here a very curious dialectic arose. American law schools had begun long before the urban immigrant became a problem. Even the peculiarly American notion that legal education was professional "graduate" education, which should occur subsequent to four years of "undergraduate" college education in the liberal arts, had existed prior to the 1880's and 1890's. By that period there were two alternative routes to the bar. One was through apprenticeship. The other was through attendance at a law school. University law faculties had grown both in size and prestige. They were anxious to "upgrade" legal education by destroying the apprenticeship route and the non-university-connected law schools which typically admitted students who had not had college educations.

At the same time, the established bar and business community, composed largely of Anglo-Saxons and the descendants of other Northern and Western European immigrants, was anxious to build barriers against the new floods of Southern and Eastern European immigrants. Because lawyers played so important a political role in America, the motivations for this effort were both narrowly economic and broadly political. An alliance was struck between law faculties anxious to improve legal education and the practicing bar and the business community anxious to keep the new immigrants out of the legal profession. The result was the creation of a system of law school accreditation which made the completion of four years of undergraduate education followed by three years of legal education at a university law school the standard, respectable, bona fide route to the profession. ${ }^{2}$

For a number of reasons, however, including a keen appreciation by all the combatants that law was the route to political power, the academic-practitioner alliance did not win a complete victory. The

2 See Stevens, Two Cheers for 1870: The American Law School, in LAw IN AmErican History (Boston, Little, Brown \& Co., D. Fleming \& B. Bailyn eds., 1971). 
apprenticeship system did die. But formal legal education remained more diverse than the university faculties and leaders of the establishment bar had desired. It must be recalled that in the spirit of nineteenth century American laissez faire, education was far from a state monopoly, as it was in Europe. In total numbers the university law faculties were overwhelmingly those of state universities. But the most prestigious of the university law faculties were those of private universities, such as Harvard, Yale and Columbia. More generally, American education was an incredible mixture of public and private, large and small, general and specialized educational institutions. Some were state institutions; some were charitable trusts; and many were private, profit-making ventures run by entrepreneurs who considered education a business like any other.

If higher education had been a state monopoly, once apprenticeship was killed the handful of state universities would have totally controlled entry into the legal profession. Their admissions policies would then have become the ultimate determiner of who had access to the profession. Given the absence of state monopoly, the outcome was very different. The major university law schools were not able to cut off the growth of private urban law schools which were created or expanded to meet the demands of the new immigrants for legal education. Many of these schools did not require that their students complete four years of undergraduate education before undertaking legal studies. Most had part-time and night programs that allowed the children of workers and small shop keepers to gain a legal education while working to support themselves. Some of these schools were connected with - and indeed often the most flourishing part of - Catholic universities that grew to serve the needs of the Catholic Italian and Slavic immigrants. Many, although proclaiming no religious affiliation, were overwhelmingly Jewish. And others yet were flourishing business operations open to anyone who could pay the fees. The growing use of state-controlled bar examinations, which had initially been conceived as yet another barrier to the immigrants, actually had the opposite effect. For it soon became evident that a student could learn the law necessary to pass the bar examination just as well in a loft on the Lower East Side of New York as he could within the ivy-covered walls of Harvard. The fact that their students were passing the bar examinations was a rough but quick mode of certifying the legitimacy of the new law schools.

The end result of the process was that while formal legal educa- 
tion was greatly upgraded in the United States, the children of the urban immigrants soon entered the legal profession in large numbers. And if for no other reason than the prejudice against them among the old Americans, they turned to serving the legal needs of their own people. Thus, lawyers drawn from among the immigrants served as a link between the Anglo-Saxon courts and the non-AngloSaxon urban masses.

Nor did the courts themselves long remain entirely Anglo-Saxon. The role of American political parties in establishing access to justice has not been much commented upon, nor at first glance is it easily comparable to developments in Europe. But comparison is possible if we think less in terms of party as such than in terms of political and social notables. I do not know if there is much literature on the subject, but surely European villages must often have been marked by a phenomenon that has been observed in Mexican and Lebanese villages, namely that simple people confronted by a complex and distant legal system turn to a local notable for assistance in obtaining justice. That notable might be priest or landholder or political leader. While knowing little of the matter, I would guess that today the continental socialist parties, packed as they are with lawyers, must provide linkages between their working class membership and the court system.

In the United States the party "machines" of the big cities provided a vital link between the immigrants and the courts during the last part of the nineteenth and the early part of the twentieth centuries. This linkage was established in many ways. First of all, judicial office was not a matter of career but of political patronage in the United States. Judges were either elected or, more frequently, appointed by the elected executive. And they were appointed from among practicing lawyers who had themselves been politically active. Thus, political party leaders were the effective selectors of judges, and many party leaders became judges, often maintaining party leadership roles even while serving as judges. Indeed, after a period of service as a judge, many returned to the practice of law and active political leadership. The municipal judges with whom most immigrants had to deal were themselves deeply embedded in the political party organizations which derived their power from immigrant votes. ${ }^{3}$

\footnotetext{
${ }^{3}$ For a late survival of party patronage judges see M. Levin, Urban Politics And THE Criminal Courts (Chicago, University of Chicago Press, 1977).
} 
Secondly, the sons of immigrants began to emerge from the law schools and to enter that mix of law practice and political activity so typically American. They soon became politically active practitioners whom the political machines rewarded with judgeships for their party work. So, after an appreciable time lag, the urban bench filled with judges of the same ethnic backgrounds as the lawyers and the litigants.

It was also in the late nineteenth and early twentieth centuries that American cities saw the growth of police forces. Like judgeships, positions in the police were patronage jobs in the control of the political machines. The Irish cop is a cliché of American culture. Police drawn from the immigrant populations served as an important link to justice. The American police were far less militarized than those of the Continent and far more directly embedded in the neighborhood life along their beats. ${ }^{4}$ They themselves solved many minor conflicts and dealt with many minor offenses without making the arrest that triggered the more formal aspects of the justice system. "Police courts," in which both the judges and prosecutors were policemen, handled many of the minor offenses for which arrests were made. Some American cities continued to employ police prosecutors in low-level municipal courts until the 1940's and 1950's. The police and the municipal judges drawn from the immigrant communities created, at least for minor criminal and civil litigation, a familial style of justice, administered informally and more attuned to the values and customs of the local community than to the black letter law of the appellate courts. ${ }^{5}$

The big city political machines with their patronage politics bought the loyalty of the immigrants by giving them government jobs. Among those jobs were judgeships and positions and promotions in the police. The parties did more, however, than serve as a conduit for the immigrants into the justice system. The basic service the parties performed for the immigrants was to act as a buffer and go-between for them in any and all their dealings with government. If their son were arrested, the worried Italian parents did not seek out an attorney. Instead, they went to a ward boss or precinct

4 See J. Richardson, Urban Police in the United States: A Brief History (Port Washington, N. Y., Kennikat Press, 1974).

5 For a description of one of the last surviving municipal court systems of this style see Bing \& Rosenfeld, The Quality of Justice in the Lower Criminal Courts of Metropolitan Boston, 7 Criminal Law Bulletin 393 (1971). 
captain - to the local party leader who marshalled their votes at election time. He dealt with the police, or the prosecutor (who was himself invariably a local, elected politician). He might even have a word with the judge. If the matter were serious enough, he would put the parents in touch with an attorney. The party would help to fix problems of justice just as it helped to fix problems of building inspection, obtaining city licenses to do business, and in other matters where the immigrant was touched by the machinery of government.

Again, one must not paint an ideal picture. The immigrants were confused by an essentially foreign system of law. The poor were often treated harshly and unfairly by the legal system, particularly where one of the litigants was old American middle class and the other immigrant worker. Thus, in such vital areas as landlord-tenant, creditor-debtor and employer-employee, the legal system was cruelly biased against the urban poor.

Nevertheless, it must be stressed that it was precisely because of what are frequently considered the worst features of the traditional American legal system that it was far more responsive to the immigrants than it otherwise would have been. Because there were not career judicial and police civil services, but instead judgeships and police jobs which were at the disposal of local politicians, judicial and police ranks quickly filled with the sons of the immigrant voters who backed the party machines. Because legal education was dispersed, of widely varying quality and not under the unifying control of the state, all sorts of people from all sorts of family backgrounds became lawyers. And then those lawyers who were most entwined with the daily political life of their neighborhoods and least learned in the law became local judges. The result of this disorderly mix of local politics and local justice was a court system far more accessible to the immigrants than would have been a judicial corps characterized by high education, competitive entry and career service which would inevitably have been dominated by old Americans of upper middle class background.

This report has spent so much time on constitutional and historical matters because American approaches to the access to justice problem even during the second half of the twentieth century have continued to be largely determined by their constitutional and historical sets. For example, we have noted that, in a new country spreading across a continent, access to justice was almost inevitably 
defined primarily in terms of the sheer physical problem of creating enough courts fast enough. The United States reached the Pacific some time ago, although it must be remembered that the nation is still so new that it created its last two state court systems - those of Hawaii and Alaska - only within the last few decades.

\section{Court Overcrowding}

The frontier problem remains with us in another guise, however. For a set of complex reasons that no one seems quite to understand, the amount of litigation has increased enormously in the period following World War II. America has been adding judgeships and building courtrooms at an enormous rate. The bar has absorbed an incredible number of new lawyers - and we still have not caught up. For these reasons Americans have seen access to justice principally as a problem of lagging court calendars. Their energies have largely been devoted not to questions of who ought to have access to the courts, but to providing enough courts quick enough for those who do have access to them. Far more time and money has been spent on meeting the demands of those who have the resources to find their own way to court than on assuring access to those not now clamoring for admission.

This concern with the problem of court overcrowding has had some unusual consequences. Americans have become increasingly interested in the many European experiments with neighborhood courts, mediators and so on, which are described so thoroughly in the volumes that comprise the Florence Access-to-Justice Project Series. ${ }^{6}$ While one occasionally hears Americans speaking about these experiments in social justice terms, as have the speakers at this conference, the driving force behind this new interest is quite a different one. These "sub-judicial" modes of conflict resolution are attracting American attention because they are promising modes of cutting off disputes before they reach courts and thus reducing the

6 Access to Justice: A World Survey (Vol. I of the Series, M. Cappelletti \& B. Garth eds., 1978); Access to Justice: Promising Institutions (Vol. II of the Series, M. Cappelletti \& J. Weisner eds., 1978/1979); Access to Justice: Emerging Issues and Perspectives (Vol. III of the Series, M. Cappelletti \& B. Garth eds., 1979); Access to Justice: The Anthropological Perspective (Vol. IV of the Series, K.-F. Koch ed., 1979); all Volumes published by Sijthoff and Noordhoff of Alphen aan den Rijn and Giuffrè of Milan. 
overcrowding of court calendars. In this sense Americans may be backing into extending access to justice down the socio-economic scale through their desire to provide more efficient court services for those who can well afford to go to court.

Recent American experience with arbitration is instructive in this regard. In common with most industrialized nations the United States has experienced a tremendous growth in labor arbitration and, more generally, in arbitration of contract disputes. Today, arbitration clauses have become standard in many forms of business contracts. Above and beyond this development, however, there has recently been major interest in arrangements whereby suits that have been filed in court but involve relatively small sums of money will be assigned to "arbitrators." The details vary greatly from jurisdiction to jurisdiction. In some, the arbitration is more or less binding. In others, if either party is dissatisfied, he may move on to the courts. In some, the assignment to arbitration is at the election of the court. In others, the parties must volunteer. But the motivating force in all these arrangements is to reduce the flow of cases onto overcrowded court dockets. And this motivation is crucial in determining the nature of the arbitration. For when one looks at the rules of these arbitrations, their procedures, and at the persons who do the arbitrating, the arbitration turns out to be simply fast, relatively inexpensive jüdging. The arbitrators are practicing lawyers. In training, experience and outlook, there is little to differentiate them from the judges. They are not supposed to introduce elements of mediation, but to arrive at the same judgment according to law that a judge would have reached. The procedures are adversary. The rules of evidence apply, but the proceedings are somewhat less formal than they would be in a courtroom.

What are the virtues of this system? Certainly not that it provides a simpler, more mediatory form of justice more directly accessible to those who are not well versed in law or able to employ legal counsel. In reality, the only virtue of the system is to provide a cheap judge, for this kind of arbitrator is in reality a judge whose hourly charges cost the taxpayers and litigants far less than the time of official judges with their high salaries, retirement benefits and, above all, their tremendous administrative overhead of courtrooms, clerks, bailiffs and so on. Moreover, as temporary, part-time employees, the number of arbitrators can be increased or cut back to meet changes in demand. As the formal courts reduce their backlogs, the number 
of cases sent to arbitration and the number of arbitrators can be reduced, while if the corps of judges is expanded, there is no hope of ever cutting it back again. Here again, the central problem is not seen as extending justice services to strata of society not previously served, but as providing a high level of service at reasonable cost to the state for those who have traditionally been served and who have recently greatly increased their demands.

Thus, particularly on the civil side, the American scene continues to be dominated by the historical task of expanding the regular court system fast enough to keep up with the geographic and economic growth of the nation. Government has been so busy meeting a clamoring market demand from those who can afford to buy that it has had little time to think about expanding judicial services to those who cannot afford to enter the current market.

\section{Legal Assistance in Criminal Cases}

This essentially laissez-faire attitude has been seriously modified on the criminal side, however, by that second great American continuity, preoccupation with the Constitution and constitutional rights. It is in the context of the constitutional law that the United States has most fully moved from a negative to a positive - or welfare state in the realm of access to justice. We have seen that the right to counsel, like the rest of the Bill of Rights, was at first seen as essentially negative. And it is still seen that way in the sense that it is still viewed as a barrier against government oppression. Yet, by a curious dialectic the right to counsel has served as the vehicle for converting American consciousness from a negative to a more positive approach to access to justice for those without the means to buy their way into our ever-expanding court system.

The story is familiar and can be told very briefly. It was not until Powell v. Alabama in 1932 (387 U. S. 45) that the Supreme Court of the United States hinted that the Sixth Amendment might require the state to provide defense counsel to indigent criminal defendants. Its actual holding was limited to capital cases in which the defendants were clearly incapable of adequately defending themselves. Long before the decision in Powell, however, many states had begun to provide some criminal defense services. The prevalent system was that of assigned counsel, one well suited to the American tradition of 
private charitable endeavor rather than government provision of services. Either by statute, rules of court, or voluntary arrangement, members of the bar in private practice took turns at providing criminal defense for the poor. They either did so without fee or were paid relatively low fees by the courts. Here again, our old friend patronage enters the picture. In many cities struggling young lawyers broke into practice by hanging around the courts picking up assignments from the judges and so earning court-paid defense fees until paying clients began to appear. In a few cities the assignment system was supplemented by a private organization of lawyers. Such legal aid societies were supported on a combination of state-paid assignment fees, charitable donations and donations by lawyers of their time. Such societies maintained a full-time staff of lawyers available to defend the poor in criminal cases.

These essentially private, voluntary and charitable attempts to provide counsel were, of course, typical of nineteenth century laissezfaire America. The Progressive Movement, which flourished around the turn of the century, challenged older American anti-government attitudes on many fronts. One minor feature of its program of expanding government services to the people was that of the Public Defender. In states like California which were heavily influenced by the Progressives, a few cities established public defender offices supported by municipal funds and organized as a regular department of city government. One of the major features of Progressivism was "good government" and "municipal reform," that is, the breaking up of the old urban party machines and their replacement by nonpartisan, career civil service, city administration. Public defender officers were supposed to follow a model comparable to the European tradition of a distinct career track for lawyers in government service. Young lawyers were to be chosen on the basis of merit for entry into the service and then to work their way up to higher ranks in the office.

The public defender movement has been quite incomplete. Even in California, one of the largest cities, San Diego, continues to contract with a private association of lawyers to provide defense services to the indigent. So does the largest city in the United States, New York City. Even where public defender offices exist, they have not fully developed the European style of a government lawyer career track. Instead, it has been typical for such offices to take on large numbers of just-graduated lawyers, most of whom stay for a few 
years to gain trial experience and then move on into private practice. Only a small proportion remain in government service to become career defenders. ${ }^{7}$

This diverse and patchy mixture of private and public endeavor to provide criminal defense for the poor was not altered in its fundamentals by the constitutional drive of the Supreme Court headed by Chief Justice Warren, but it was massively expanded in the extent of its coverage. In Gideon v. Wainwright (372 U.S. 335) the Supreme Court in 1963 declared that no state might convict an accused of a serious offense without providing him counsel if he could not afford to retain his own. In Gideon the Warren Court sought to do what it sought to do in many areas of law, to turn an essentially negative right against government into a positive right to government services. The Warren Court pursued the value of equality down many constitutional byways. Its goal, often not fully perceived even by the Justices, was to constitutionalize the welfare state, to create constitutional rights to at least a minimum of government-supplied subsistence, housing, education and employment. ${ }^{8}$ To put the matter bluntly, the Court sought to wield the political power of judicial review to force American legislatures into welfare state programs that the legislatures were unwilling to undertake. In this crusade the Warren Court largely failed. Its lines of attack were blunted and rolled back by the Nixon appointees. One firmly surviving remnant of the Warren Court movement is the translation of the right to counsel into the duty of government to provide counsel. Following Gideon, what had been incomplete, widely varying systems of access to criminal justice for the poor did become a relatively uniform national program. We can now say with some confidence that every indigent criminal defendant in the United States who wants a lawyer gets one. Moreover, few states have really attempted to strictly enforce the indigency requirement, so that free public defense is now provided not only for the very poor, such as the unemployed, but also for the working poor. Indeed, since the bulk of criminal defendants are young persons who show few capital assets no matter what their class or family background, the children of the middle classes

7 For a general description of the contemporary urban scene see H. JACOB, URBAN JUStice: Law \& Order in American Cities (Englewood Cliffs, Prentice-Hall, 1973).

8 See Shapiro, Supreme Court and Economic Rights, in Essays on the Constitution of the United States 74 (Port Washington, N. Y., Kennikat Press, M. Harmon ed., 1978). 
who run afoul of the criminal law are a substantial component of those availing themselves of government-financed defense services.

In line with traditional American developments, then, the access problem was seen as essentially a constitutional problem. A major change in constitutional law initiated by the Supreme Court caused a really fundamental shift to universal, complete access to criminal defense services. Today, it is still widely debated whether assigned counsel systems are adequate and whether even public defender offices provide the same quality of legal services as do private defense attorneys. But because the constitutional right is firmly established, the access to criminal justice is firmly established.

Earlier, we spoke of a curious dialectic at play in this area. The first stage of that dialectic was the conversion of a negative constitutional right to counsel into a positive one. The basic premise of this stage, however, remained an essentially limited government view of the Constitution. Precisely because criminal prosecution was an infringement by government upon the liberty of the citizen, it must be limited by the presence of defense counsel alert to protect the rights of the accused. And if it were necessary for the government itself to pay the costs of making such a constitutional limitation upon its powers effective, so be it. Thus, the constitutional right to counsel is limited to criminal proceedings precisely because it is in those proceedings that the state seeks to thrust itself on the individual, as opposed to civil proceedings in which the individual is attempting to make a positive claim to state conflict resolution services.

Yet, the spectacle of an increasing number of tax dollars being spent to provide the criminal poor with legal services in criminal cases while the deserving poor get no such services for civil matters must appear anomalous over time. Thus, the constitutional thrust of American access to justice now provides a basic tension or contradiction that will inevitably fuel further movement toward converting right to counsel to a complete, positive claim to legal services on the civil as well as the criminal side.

\section{The Due Process Revolution}

Another constitutional development pushes in the same direction. Americans sometimes refer to it as the due process revolution. As a direct response to the growth of the welfare state, American courts 
ceased to treat government largesse, either in terms of government jobs or welfare payments, as a privilege which the government might grant or withhold on demand. Instead, they began to treat such government benefits as a species of right or entitlement protected by the clauses of the Constitution that command that property may not be taken without due process of law. ${ }^{9}$ Concretely, this meant that government was increasingly required to provide hearings before terminating benefits or dismissing employees. In the American experience the right to a hearing is inseparably tied to the right to an attorney. Yet because the right to counsel of the Sixth Amendment is confined to criminal matters, the right to a hearing - read as the right to an attorney - of the due process clauses is now conceived to be only a negative right. It is a right to use an attorney against the government, but imports no obligation on government to provide representation for its employees or other beneficiaries. Here again, an anomaly arises with great potential for affecting future development. Surely, it does little good to tell a welfare recipient that he has a due process right to employ legal representation at a hearing to terminate his welfare benefits. If he had the money to hire a lawyer, he would not be on welfare. The dynamics of due process are another force thrusting right to counsel in more positive directions. ${ }^{10}$

\section{The Quest for Equality}

Behind these particular constitutional pressures lies an overarching one. While it is dressed in various guises, such as due process or adequate political representation, the central value of modern American constitutional thought is equality. The search for equality dominates nearly all discourse among American constitutional scholars, although few of them frankly admit it. The courts are even less frank, but they nonetheless pursue the value. The constitutional thrust toward equality is bound to move the whole legal system toward greater equality of access.

9 See Michelman, Formal and Associational Aims in Procedural Due Process, in Due Process (Nomos XVIII) 126 (New York, New York University Press, J. Pennock \& J. Chapman eds., 1977).

10 See, e.g., Michelman, The Supreme Court and Litigation Access Fees: The Right to Protect One's Rights - Part II, 1974 Duke Law Journal 527. 


\section{Justice And Politics}

If on the one hand we have stressed the domination of American access to justice by constitutional considerations, on the other we have stressed the intimate connection between justice and politics. By the post-World War II era, the old rural America of country lawyers and country judges closely linked to the people had largely disappeared. In urban America the urban political machines were faltering. Perhaps more important, because of lags in political absorption, it was no longer Irish, Italian and Polish judges facing Irish, Italian and Polish litigants, but Irish, Italian and Polish judges facing black litigants. Both the community feelings and the direct services provided by the immigrant-oriented political machines had been largely replaced by black-white tensions.

The "war on poverty" of President Lyndon Johnson reflected this reality. It also reflected, however, a dominant ideological strand that had sprung from American social science - and particularly political science - of the 1940's and 1950's. Often led by such refugee European scholars as Hans Morgenthau, American political science had come to focus upon "power" as the central phenomenon of politics. And feelings of powerlessness had come to be identified by psychologists and sociologists as major symptoms of individual and social pathology. At the vulgarized level of public policy, this focus on power was translated into a simple theory of social changes. Providing welfare services to the poor - that is, giving things to the poor - had not eliminated poverty. Why not? Obviously because what the poor needed was not welfare but power. Armed with power, the poor could extract what they needed from the society; but even more important, they could feel self-efficacious in doing so and thus break out of the culture of poverty. It is important to understand that the movement of the Johnson years was not simply an increase and extension of social services to the poor. It was an effort to transfer political power to the poor by creating a political infrastructure among the poor. In short, the poverty warriors were bent on getting the poor to organize themselves for political action. ${ }^{11}$ 1969).

11 See D. Moynihan, Maximum Feasible Misunderstanding (New York, Free Press, 
It is in this context that the various legal services programs of the 1960 's, which have been described by other participants in this conference, must be seen. Whatever Congress' intentions, the intention of the Johnson administration and those who staffed these programs was not simply to provide representation for the poor in the mine run of civil cases in which the poor were involved, such as credit, rent, divorce and tort litigation. Instead, legal services were seen as part of an agenda for seizing political power.

Here we must pause to take up a point which is central to clear analysis of access to justice at least in the American context. (It might be fruitful to discuss whether it is any less central in the European context.) Access to justice may be defined in an essentially conflict resolution way. If so, access becomes simply the question of whether all persons in the society have access to triadic modes of dispute settlement. And justice is seen as impartial dispute resolution. In this context justice means individual justice. Access to justice may be viewed in an entirely different way, however. In the United States courts have not only been major individual conflict resolvers, but also major makers of law and public policy. Litigation has been not only a dispute settlement mode, but also a major mode of political action aimed at reshaping public policy. ${ }^{12}$ In this context access becomes access to the tools of political power and justice becomes not individual justice attained through dispute settlement, but social justice attained through the creation of new law.

The lawyer brigade of the war on poverty thought it could do more for the poor by acting as their vehicle for seizing power in the law-making process than by representing them in individual disputes under existing law. They devoted their greatest energies to test cases and other forms of lobbying designed to create new law beneficial to the poor. The Johnson war on poverty foundered for any number of reasons. In this foundering the Congressional reaction to the lawyer brigade was intense. The result which has been described here in more detail by others, was the creation of the Legal Services Corporation, a deliberate attempt by Congress to move from a political power to a dispute settlement mode of access to justice.

Yet, Americans are so wedded to the coupling of law and politics and to litigation as a political weapon that the set of the Johnson

12 See D. Horowitz, The Courts and Social Policy (Washington, D. C., Brookings Institution, 1977). 
years has not disappeared. Poverty law remains, as several participants in this conference have observed, representation of the poor not only in the narrow setting of routine dispute settlement, but also in the broader setting of law-making through litigation and lobbying. Law as politics continues to flourish.

\section{Conclusion}

Why in a paper which was to be devoted to access to justice and the welfare state has so much time and attention been devoted to essentially historical considerations? Because, at least in the American setting, what is meant by the welfare state is highly problematic and highly conditioned by certain major themes of American experience. Three such themes have been identified. First has been the American preoccupation with court building. Second has been the preoccupation with constitutional rights. And third has been the intimate relation between access to justice and politics. Taking the three together, what prognosis emerges for the immediate future?

First, the American legal system will not devote itself solely or even largely to access to justice in the sense of extending justice services to those who have not traditionally made money demands for them. American energies will be principally devoted to what they have always been devoted to, providing more and more justice services to meet a continuously increasing demand by the business community for such services. Most new access to justice for the poor will come as spin-offs from efforts to clear the courts of "minor" cases so that they can more efficiently handle those involving larger sums of money.

Secondly, the pace at which access to justice is enlarged will be determined far less by self-conscious assessments by legislatures of the need for welfare services than it will by assertions of constitutional rights in the courts. Thus, the pace of change will be determined in good part by the accidents of what persons are appointed to the higher reaches of the courts.

Thirdly, access to justice will be seen as a political problem. It is too late in the day to claim that we are simply talking about whether to supply legal services to the poor as we might talk about providing health services or transportation services. Everyone in the game knows we are talking about access to political power. The willingness 
of the middle classes to enhance the political power of the poor will play a major role in access developments. In short, we must see the problem not only as one of access to justice and the welfare state, but also as one of access to justice and the democratic state.

Fourthly, the United States will not adopt monolithic solutions to these problems. American experience with every device for increasing access, from codification to night law schools, public defender offices and small claims courts, has been one of incompleteness. Remnants of old devices remain as new ones appear. Each has advantages and disadvantages. None seems to be the panacea that it first appeared to be. Increased access will occur through the proliferation, not the rationalization, of devices. If the notion of the welfare state is one of comprehensive, rationalized services, then the United States is unlikely to be a welfare state. Instead, we may wish to speak of the services state, with the emphasis on the plural s. Moreover, we must anticipate that the services will be provided by the usual American random mixture of public and private sources and that many of the services will be directly related to political action and organization. In this connection recent actions by the United States Supreme Court and the regulatory commissions to break up monopolistic bar practices, ${ }^{13}$ such as the prevention of advertising by private attorneys, may have more impact on access to justice for the average American than have government-supported legal services programs.

Finally, and it is typical of the American scene that this point has been so continuously implicit that I have not made it explicit until now, the American bar, which is highly diverse and fragmented, will play a major part in determining the velocity at which access to justice expands. Access to justice has more to do with the politics of the legal profession in the United States than in probably any other country in the world. In this connection perhaps it is well to remember that many of the papers presented at this conference are not only scholarly analyses but political manifestos prepared by lawyers who are central actors in the ongoing political process of determining the scope of access to justice in the United States.

13 See Bates v. State Bar of Arizona, 433 U. S. 350 (1977). 



\title{
ACCESS TO THE LEGAL SYSTEM \\ AND THE \\ MODERN WELFARE STATE:
}

\author{
A EUROPEAN REPORT \\ FROM THE STANDPOINT \\ OF AN ADMINISTRATIVE LAWYER
}

by

HARRY STREET

Professor of Law, University of Manchester

This Colloquium has a structure organised around three basic developments: legal services for the poor, the protection of diffused and fragmented interests, and reforms going beyond the provision of legal services. This fourth session is to concentrate on access to the legal system and the Welfare State.

Plainly, this paper must focus on what is not already fully covered either in the admirable volumes already published in the Florence Access-to-Justice Project Series or in the first three sessions of the Colloquium. What marks off this fourth session from its predecessors is its emphasis on the Welfare State, or as Professor Cappelletti puts it in his Colloquium Description, the "promotional, activist state".

It seems logical to begin by asking what is special about the Welfare State which creates particular problems of áccess to justice? I can answer that question best by examining what problems have arisen in the jurisdiction with which I am most familiar: the United Kingdom.

\section{Increased Power of Public Officials over Individuals}

Professor Cappelletti understandably stresses the need to reconcile these new activities of the State with the objective of recognising, and indeed reinforcing, the ideal of private individual freedom and initiative. One characteristic of the Welfare State is the increased 
power of public officials over individuals. The need to protect citizens' rights against this interference gives rise to many issues of justiciability.

The legal system must deny officials any procedural advantages in proceedings where their accountability is in question. The citizen must have accessibility to information for the better conduct of his legal proceedings: if he needs to identify the officials responsible, he must be legally enabled to do so and he must not be denied access to information in the hands of officialdom on the plea that it is a state secret or that it is not in the public interest to disclose the contents of confidential files, with their internal minutes and memoranda. If tribunals other than the ordinary courts - some form of administrative jurisdiction - are set up to adjudicate separately on questions of official accountability and liability, whatever facilities there are for legal advice and aid must not be restricted to the ordinary courts. It happens all too frequently that for the purposes of financial aid in litigation countries distinguish the ordinary civil courts from all other adjudicative institutions.

It is highly desirable that the powers and duties of officials be given sharp legal definition. What happens if this does not occur is illustrated by the rules in the United Kingdom regarding the police powers of interrogating suspects. They are contained in the Judges' Rules, a statement which does not have legal force but whose sanctions lie in the discretionary power of the judge in a subsequent trial to refuse to admit evidence which has been obtained in breach of the Judges' Rules. These rules deal with such matters as the right of the suspect to be informed of the facilities he should have for communicating with his lawyer before he answers questions. Because these "rights" are not law, police officers feel free to disregard them in the interests of procuring confessions of crimes; they forecast, rightly, that even though the confession might not have been obtained had the accused had his lawyer present, that will not stop the court from convicting the prisoner on the strength of his confession. Accessibility, then, in this aspect of State activity, demands definition of a citizen's rights in law.

The powers of officialdom are regularly exercised by individuals low down in the administrative hierarchy, although nominally the legislature has entrusted the functions to a superior administrative body. These functions are on their face discretionary, leaving it to the administration to decide how in practice they will wield them. 
Within the Administration directions are given to the minor officials on how they are to perform their duties; what appears at the level of the superior body to be a massive unfettered discretion proves to be a tightly restricted power in the hands of the minor official who actually confronts the citizen. Yet only too often the citizen does not know, and has no means of knowing, to precisely what rules the official dealing with him is conforming. It is a prerequisite of access to justice that the individual has prior accessibility to the instructions on which the official relies when interfering with the citizen's freedom. This aspect of the right to know will be treated separately later.

\section{Government Regulation of the Economy and Industry}

As economic problems become increasingly complex and international in their implications, states more and more conclude that the entrepreneur cannot be left to his own devices. Government sees the solution in its regulating the economy and industry. Much of this intervention does not concern us here, because its impact is general, on the country as a whole, rather than on the individual. Accessibility to justice has no meaning with respect to controversies on issues of high policy which are not in their nature justiciable. In that sense the Welfare State often minimises, rather than intensifies the role of the judicial process.

The economic regulatory role of the State bears on access to justice in two contexts. Much of this interference is within a particular industry, and yet the regulations affect not only that industry, but individuals. The organised industry has its trade associations and its pressure groups, so that even though the legislation prescribes no consultative procedures preparatory to the formulation of regulations, the wishes of industry and their views on proposed policy are fully known to those who draft the regulations. On the other hand, given the normal silence of the legislative provision, the aggrieved individual is not consulted; he first learns of the content, or perhaps even the existence, of the regulation after it has been promulgated. Fundamental to accessibility to justice in the Welfare State is the opportunity of the citizen to challenge the content of draft regulations. Ex post facto judicial review restricted to grounds such as excess of power is no help to this citizen. He needs machinery which 
will, at the formative stage, disclose to him, and not merely to industry, the draft proposals of the Administration. In the United Kingdom, and one suspects in other countries, draft regulations are not made available to individuals, nor are individuals consulted before the scheme of drafts is decided.

It is only when the legal system overcomes that barrier that we reach the next question. What financial aid, if any, should the citizen be given to prepare and present his case to the Administration in the course of this rule-making process? If we are considering Justice in the Welfare State, it is an artifical cut-off point to say that our concern with the legal process in the Welfare State need begin only when it is too late to challenge the content of that outpouring of subordinate legislation which is one of the most important characteristics of the 20th-century Welfare State.

This last question is a different one from that presented in respect of access to the ordinary courts. Aid in engaging the services of a lawyer is not the essential need. In most countries the pressure group experts, the men with access to the corridors of power, the contact men, the P.R.O.'s, represent another brand of professionalism. It would be difficult to formulate rules which would quantify the reasonable financial aid for citizens engaging that kind of professional help in their struggle for fair treatment. Yet it is thought that it is to ignore realities of the dilemma of the citizen confronting the State and organised industry, too, not to acknowledge that effective assistance and accessibility is in this context not solely a matter of helping him to pay lawyers' fees.

It would be misleading to see government's economic and industrial intervention as a threat only to individuals; the protection of private enterprise is also involved. There are two obstacles here to the proper functioning of the judicial process. Most sophisticated legal systems have judicial review of government action for determining whether there has been an abuse of power - the exercise of a function for a purpose other than that envisaged by the legislature. The problem is how to use the judicial process to establish the abuse. Take a recent United Kingdom problem, no doubt having its equivalents elsewhere. Government has the power under statute to grant export credit guarantees to enterprises of its choice. At the same time, it supports a wages policy which limits increases in pay to an annual maximum of $\mathrm{x}$ per cent. Believing that $\mathrm{Y}$ company is about to breach those pay policy guidelines it quietly hints to Y's 
directorate that its export credit guarantees will be withdrawn if it does not heed the government's pay policy. Y company might contemplate seeking judicial annulment of withdrawal of the guarantees for abuse of power - conformity to wages policy was not contemplated by the legislature as a matter relevant to the exercise of the discretionary power. Y company's access to the courts for judicial review of administrative action is meaningless unless the judicial process makes available to $\mathrm{Y}$ company and the reviewing court the government files which alone will disclose whether in fact discretionary power was abused.

\section{Expropriation of LAND ANd Control of Its Use}

In the United Kingdom, perhaps the largest complex of legal controversies arising from the Welfare State has been concerned with expropriation of land and control of its use. What is specially difficult here is that at one level the conflict is between government on the one hand, and a landowner or developer on the other, and yet at another level there is the interest of the amorphous general public. They are concerned, too, with where the airport, the motorway, the prison, should be built. The United Kingdom's general administrative solution, i.e., a public inquiry preceding Ministerial decision, has much to commend it.

The big questions concern representation of the public. Should interested members of the public be given precisely the same right to be heard as the acquiring public body, the landowner menaced by expropriation, or the property developer? If there is an appeal process to a superior court, do aggrieved members of the public have locus standi? Again, if the answers to these questions are Yes, are they to have ready accesibility to official information, help in proffering the expert scientific and technical evidence which, as much as legal representation, is at the heart of these administrative processes?

The dangers of going too far on accessibility are illustrated by recent United Kingdom experience. Great heat and passion are generated over the routes of projected motorways, which threaten someone's amenities and others' property, wherever they go. The United Kingdom is paying the price for an unrestricted right of the public to participate in the inquiry. There has grown up a breed of 
professional protesters, who are paid by dissident groups to represent them at public inquiries. Their concern is by organised filibustering, demonstrations and incessant interruptions so to disrupt the inquiry that it can never be concluded. And so the project, it is hoped, will be delayed indefinitely. This aspect of accessibility which has arisen for the first time out of the Welfare State's assertion of land control and expropriation creates new problems which so far the United Kingdom has failed to solve. It raises the important question of what curbs on accessibility are appropriate in the interests of the orderly implementation of consistent governmental policy with due respect to public and private interests.

\section{Government Benefits}

When one speaks of the Welfare State, one often thinks first of the 20th-century role of the State as the guarantor of freedom from want. Protection against all the hazards of life: ill health, incapacity, death, widowhood, unemployment, pregnancy, childbirth, industrial accident, industrial disease, old age, poverty, parenthood, loss of parental support; all these (and sometimes others, such as accidents on the road or in the home) are now accepted by most States as in some degree a governmental responsibility. Perhaps the United Kingdom's mechanism does not deviate far from the universal norm: an original decision taken on paper by a government official with an appeal process to some tribunal which accords a right to be heard.

Nowhere within the Welfare State is accessibility to the judicial process more critical than in this area. Here is a class of litigant often unfamiliar with the legal process and lacking the financial means to pay to be represented at hearings. Nervous, inarticulate, overawed, mistrustful of bureaucracy, impatient of legal forms - he is indeed a special case. The rules governing his rights to benefit often are extremely complex. Administrative efficiency in handling millions of claims demands rules that are precise, certain even if arbitrariness in cut-off points is the price to be paid. The Administration has a special task: first, to produce innumerable explanatory leaflets in language far removed from that of the regulations themselves which set out clearly for the uninitiated and uneducated person precisely when he is entitled to a benefit, and how he goes about claiming it. Special care has to be taken about the adjudicative mechanism for this class 
of litigant. Not for him the remote august presence of the superior judge. He must be around the table with people, some of whom he sees as like himself, people to whom he can speak freely, who will be tolerant of his fumbling, discursive, often irrelevant, disorderly presentation of his case. Accessibility to justice in the land of welfare benefits is not merely helping the claimant; it is ensuring beforehand that there is a tribunal, an atmosphere, a procedure welcomingly receptive and comforting to him - the tribunal system must concentrate on its own accessibility here.

\section{CONSUMERISM}

Consumerism must be seen as one of the most recent manifestations of the Welfare State - the sustained effort by the State to reduce the natural state of unequal bargaining power between supplier and consumer which has proved to be the inescapable result of 20thcentury methods of industrial production and marketing. The individual is ineffective in influencing the content of regulations decided on by government departments in concert with industry. Increasingly, the solution is seen in the creating of government departments specifically entrusted with the task of policing industry in the interests of the consumer.

So far so good, but that leaves the inevitable residual case: the manufacturer, the retailer who violates the protective regulations to the prejudice of the individual consumer. One solution is to make irrelevant the consumer's accessibility, by having governmental agencies take legal proceedings against errant firms: proceedings which might result not merely in criminal penalties or court orders prohibiting the forbidden practice, but also in court orders requiring the payment of compensation to the deprived consumer. That proceeding is apposite where breach of regulations is complained of, but less apt where the consumer maintains that his purchase is of defective goods, or that the service he has paid for fell below what he was promised. Here problems of proof loom large, with the need often for expensive technical evidence often disproportionately costly for the consumer when compared with the maximum amount of his loss. It is for those reasons that many countries are experimenting with entirely new means of accessibility to justice. The argument runs that an arbitral process is called for, bereft of the trimmings of the ordi- 
nary court process, lending itself to ready examination and expert appraisal of the allegedly defective product or technical evaluation of the service provided to the consumer's property. Sometimes these are collectively known as small claims arbitration courts.

\section{LicENSING}

No activity of the Welfare State has had greater impact than the vast growth of licensing. It is the manifestation of the State's protective role, the recognition that the judicial system must not be content merely to redress harm already suffered, that positive steps must be taken to prevent harm. You cannot handle a car, an aircraft, a ship, without a licence. Buildings must have fire licences. Public health must be looked to - manufacturers of innumerable food products require licences before they can operate. Those carrying on occupations which affect the public closely must be licensed to do so. In times of scarcity, whether of goods, currency, raw materials or whatever, again licensing comes into its own. Almost every time a commission is set up to invéstigate some alleged abuse and make recommendations for change, among its remedies is a new licensing system.

Licensing is open to great abuse. Where licences are restricted there is scope for corruption in their grant. The interest of the public in general can be menaced. Those in certain occupational groups may seek a licensing control solely to maintain an unnecessary monopoly in their trade. The police may demand licensing in order the better to keep track of those carrying out certain activities. There is a risk of licensing being seen as the concern of government and licensee, and nobody else. If somebody unsuitable holds a licence, public initiative in seeking licence revocation is essential. Unfortunately, that kind of accessibility to justice is often denied. Where licences are revocable or need periodic renewal, the public is often denied any means of challenging the continuance of the licence. In the United Kingdom, and perhaps elsewhere, insufficient thought has been given to, and inadequate provision made for, access by aggrieved citizens to the forum vested with the power to terminate the privilege of licensees whose fitness to continue in its enjoyment is open to question. Accessibility is not here primarily a matter of financial legal aid or availability of legal advice. The main needs are 
publicity by the licensing body about its meetings at which it wields its revoking and renewing powers, full facilities for interested members of the public to make representations at those hearings, and communication to the citizen of the reasons for the decisions of the licensing body.

\section{Enforcement of Health and Safety Standards}

The traditional State functions of caring for public health and safety have expanded and, with more sophistication, given rise to new State-citizen relationships. Health and safety risks in their nature affect both the public as a whole, and some members more than others. It is proper that accessibility to the courts be seen here primarily as the concern of public authority - their's is the job of enforcing health and safety standards. Yet the law must meet the eventuality that the public body is loath to discharge its responsibilities. Where the individual suffers such harm that he is the victim of a delictual wrong, it is merely a straight case of legal aid in civil actions before ordinary courts. The tough one is where the citizen is concerned that the health or safety hazard be removed, and cannot establish a private wrong. The law must then at least enable him - or perhaps a minimum number of citizens - to institute criminal proceedings, possibly leading to a cease-and-desist order, or to seek an injunction. In English law no citizen can seek an injunction for a public wrong without the cooperation of the AttorneyGeneral, a limitation on his freedom of action. At least, the citizen who is free under English law to prosecute for crime or seek injunction can ask the court, if he succeeds, for an order that the guilty party pay the legal costs which he has incurred. This after-the-event recoupment of legal costs is some encouragement to the individual to utilise the judicial process.

\section{Special Tribunals for Protecting the Weak Individual AGAINST THE STRONG}

All the operations of the Welfare State we have discussed so far have either concerned activities of the State with direct effects on the citizen, or have related to laws conferring regulatory powers on gov- 
ernment over individuals. The Welfare State has another relevant manifestation. It institutes machinery to protect the weak individual against the strong - to interfere with the ordinary play of market forces - and these institutions are often administrative tribunals.

\section{A. Rent Control}

Rent control is an obvious example. To counteract the almost world-wide scarcity of rented accommodation, restrictions are imposed on the freedom of landlords to raise rents, and tenants are given a degree of security of tenure. Frequently, as in the United Kingdom, special officials and, on appeal, special administrative tribunals are set up to officiate in the ensuing landlord-tenant disputes. The justification for separate machinery includes a matter which concerns this paper: simple informal procedures making the litigious process cheaper than that in the ordinary courts. What is missing in the United Kingdom structure and possibly elsewhere is financial support for what is essential to success in this kind of dispute: not so much legal representation as expert evidence from professional valuers and surveyors. The question is the more acute because when landlords are commonly large property companies they have access to a fund of professional expertise and a corpus of statistical knowledge of rents which is denied to tenants. It is one important example of an issue at the heart of much of this discussion of accessibility. Presentation of a case is not always a matter of paying for a skilled lawyer's services; in so many areas into which the Welfare State now takes us, the expensive and time-consuming expert professional witness and his pre-trial preparation of documentary evidence and statistics count for at least as much as the lawyeradvocate.

\section{B. Employer-Employee Relationships}

An arguably related activity, and potentially a more important and difficult one, is intervention by the State in employer-employee relationships. Employment protection extends beyond unlawful dismissal to unfair dismissal, compensation when the job becomes re- 
dundant, special provision for the pregnant mother on maternity leave, and the like. Again, special tribunals have been set up regularly to cut down expense to litigants and utilise expertise. Such tribunals have something in common with those handling social security disputes in that there is a need to include among the adjudicators an element whom the aggrieved worker will see as sympathetic to his problem.

Industrial tribunals do create one quandary for accessibility not previously adverted to in this paper. I use the United Kingdom as my example, at the same time believing that it represents a general consideration. So far, pressure to extend the system of legal aid to these industrial tribunals has been resisted. The opposition has not rested solely on the familiar objection that the country cannot afford it. Employers say that already ex-employees bring actions for their "nuisance" value. Dismissed for what the employers are satisfied to be good reasons - absenteeism, inefficiency, insubordination, bad time-keeping and the like - they nonetheless take their employers to the industrial tribunal, claiming compensation for unfair dismissal. Employers find it cheaper to buy off these unmeritorious claims with a settlement of a few hundred pounds rather than face a day in court when, even if victorious, employers have to pay the salaries of key managerial personnel whose day is wasted through attending as witnesses. How much worse, the argument runs, this situation would be if every dismissed employee could appear before an industrial tribunal backed by skilled legal advocacy provided free at the State's expense. The problem is a real one, and perhaps of quite general application.

One other aspect of accessibility of peculiar concern in this respect is sufficiently important to merit separate consideration later: representation by trade unions of their members involved in litigation.

\section{National Health Service}

I am well aware that the United Kingdom's National Health Service does not have its equivalent everywhere else. Yet it is a microcosm of some of the Welfare State's peculiar dilemmas over accessibility. The medical profession is one of the United Kingdom's most powerful pressure groups - and that surely is not a peculiarity of my 
country. The price of their participation in a nationalised scheme of State medicine - and one which fell short of making doctors State employees - was a system which afforded doctors exceptional protection against complaints by National Health Service patients. Naturally, there is machinery whereby aggrieved patients can ventilate their complaints, and there is the ultimate sanction of disqualifying a doctor from participation in the National Health Service. The United Kingdom, however, has signally failed to provide a system of administrative jurisdiction which affords patients the fullest opportunity - on terms of equality with the challenged professional - to present his complaint, backed by medical expert evidence, and to have recognition of his interest, as well as the doctor's interest in continuing in the Service. It has also failed to provide adequate representation of the lay public, as well as the medical practitioner, in the hierarchy of appellate tribunals available to the practitioner complained against.

\section{A First General Conclusion}

My first general conclusion is that it is impossible and unwise to attempt to isolate totally the problems of accessibility. There is one big enveloping issue: justice in the Welfare State. The content of the laws, the ways they are made, the facilities for the public to know what is happening, the organisation of the adjudicative bodies, their procedures, the complexity or simplicity of the law they apply and that law's accessibility to the citizen, his sources of advice, availability of and forms of representation, methods of dispute solving, and appeal procedures: all these matters interlock, and one cannot appraise any one country's efficiency in operating a Welfare State without having this in mind all the time.

\section{The Problems of Reform in the Area of Welfare State LAW}

Access I see primarily as how best to utilise a country's available financial and human resources. How much money is a country able to spend on it; what proportion of its income should it spend? What arrangements give it the best value for money? What proportion of 
the legal skills of a country should be devoted to it? How do you devise a system which draws in the greatest depth on skills either actual or capable of being developed?

\section{A. Legal Education}

No doubt legal education should be organised so that lawyers have a training which enables them to specialise in those areas of Welfare State law where they are required. I suspect that the United Kingdom is not alone in having few lawyers with expertise in the law of social welfare, compared, say, with those experienced in criminal or family law. The circle must be broken. Hitherto, professional training has not concentrated on these areas because tomorrow's lawyers have seen no living to be made out of that law, and when the call has come for welfare lawyers, experts are not available. My own view is this lack of professional legal interest has had other adverse consequences. The rules of social welfare law are unnecessarily complex and badly drafted. This is partly because no fund of expert criticism has been brought to bear on the civil servants' drafts. They have not been subject to that judicial scrutiny and often adverse comment to which, say, tax legislation is subject.

\section{B. Para-Legals}

When, as is usually the case, this complexity is accompanied by inadequate treatises and manuals, it has a further drawback for accessibility. The sheer volume, and the small amounts at stake with respect to social security and other similar disputes, make it arguable that representation below the level of trained lawyer is sometimes appropriate. In my wide experience of chairing social security tribunals, para-legal advocacy has been generally inadequate. There are few lawyers capable of and available for training non-lawyers: the legislation is bafflingly complex and statutory interpretation is a mysterious art. The non-lawyer does not readily acquire a sense of relevance with regard to evidence; he finds it difficult to be unemotionally objective. I do not despair. If the matters adverted to above are looked to, para-legal representation would sometimes be feasible. It is simply not enough to have professional social workers give 
courses to other social workers, have them audit sessions of the relevant tribunals, and then regard them as suitable advocates.

\section{Legal Aid}

Given that few countries will be able to afford to pay out of State funds the fees of lawyers whenever litigants express a wish for them, the question arises how to decide which cases shall be legally aided. In ordinary civil cases the usual method has been to have an independent body decide on written applications whether a case was sufficiently likely to succeed on its merits to justify legal aid. I do not believe that method to be suitable here. Unless the independent body were itself expert in welfare law it would find that last question hard to answer. Moreover, the question is not the same here - not all cases with a prospect of success can be funded; there must be a further qualification, i.e., that the case, either because of its legal complexity or of difficult evidential matters, cannot be presented adequately by the claimant. A further point is that at present the application for legal aid is usually made by the lawyer who will act if legal aid is granted. It seems doubtful whether that will work here. I think it worthy of consideration whether the legal chairman of the tribunal concerned is not best fitted to decide which cases, in the light of the criteria outlined above, need legal representation.

\section{Trade Unions and Legal Representation}

One of the interesting questions on the United Kingdom scene is what part trade unions do and should play in legal representation. In principle, this form of representation seems to have much in its favour. Its membership is very much composed of those who need help, particularly as unions have recently greatly expanded membership below the level of craft workers. Trade unions have been most active in developing the law regarding compensation for industrial accidents. When there was scarcely any other source of legal assistance, they developed relationships with sympathetic solicitors for the benefit of their members. Union assistance in personal injuries cases in civil courts remains a prized benefit of membership. It is seen by the unions as an important aid to recruitment. 
On the other hand, United Kingdom trade unions have done little or nothing to meet the unmet need created by the Welfare State. Outside employment matters their contribution is insignificant. They are doing nothing to expand their own qualified legal staffs. This does seem to be an example of a great opportunity missed by unions. They remain suspicious of lawyers. They support their member victims of industrial accidents simply because it helps recruitment and costs them little in view of the English rule of civil litigation that a losing employer would have to pay the legal costs incurred on behalf of the successful worker. They continue to use their own unqualified representatives extensively before administrative tribunals: men who are often untrained, and find themselves attending cases for which they were quite unprepared. It would be easy for trade unions to expand greatly their legal provision for members. They could also do much more than they do to provide systematic training for their administrative personnel and shop stewards in those classes of cases where neither the complexity nor the amount at stake demands the presence of a trained lawyer.

\section{E. Expert Evidence}

Insufficient attention has been given to the provision of expert evidence. Welfare State litigation, like civil proceedings, has areas where litigious success depends as much on the quality of expert witness as on advocacy skills. In various claims for industrial injury the availability of a medical report from an orthopaedic surgeon is often decisive. Nobody is equipped to contest a rent assessment matter without the aid of a qualified surveyor and valuer. In the United Kingdom the professional associations within the valuation profession have seen it as their obligation to provide assistance for the needy. There is much more to be done within professional societies and also by way of possible state aid for witnesses in these areas of welfare law where expert evidence is critical.

\section{F. Class Actions (Test Cases and Relator Actions)}

It has often seemed to me when acting as administrative judge that much more could be done about representative class actions. 
There may be a claim for unemployment benefit where the government department denies liability on the ground that the unemployment arose from industrial action consequent on a trade dispute, whether by strike or picketing or other like activity. Maybe hundreds of workers have similar cases. There is no organised official procedure whereby one of these like cases can be earmarked as a test action and legal representation provided for an intensive consideration of that case, which would be regarded as decisive of all under appeal.

That is an aspect of class actions upon which attention is not ordinarily focussed. That is not to ignore that other variant of the class action, where the assertion of a right or redress of a grievance which is public in nature and equal in its effects on a large proportion of the public demands public prosecution. General law should recognise such actions, and the situation in the United Kingdom where a Minister holding political office, the Attorney-General, has an uncontrolled discretion whether such actions are sustainable cannot be justified. Its unfairness was sharply demonstrated recently in the United Kingdom when action against trade union officials in support of freedom of the mails was stopped by a Socialist Attorney-General who was under no compulsion to justify his veto before any tribunal.

\section{G. Conciliation}

There is much canvassing for conciliation as a substitute for, or at least a means of avoiding, the normal form of adversary proceeding. My experience of it in action is unfavourable. It makes it difficult to define the fact-finding on which results are based. In a contest between an experienced hard-headed businessman accustomed to the bargaining process as a way of life and a timid individual totally unfamiliar with the process and often feeling himself under pressure not to hold out for his full claim, the scales are unfairly balanced. What I have seen happen all too often is the surrender of the individual to a compromise which perhaps in justice he should not have accepted. I do not believe that it is a usual characteristic of Welfare State disputes that the right solution is a middle of the road compromise by way of settlement. The answer is usually black or white, and conciliation can be seen as an excuse for the adjudicator not discharging his hard appointed task of finding out 
what the facts in dispute are and applying the relevant law to them. Welfare State law is not the same as industrial bargaining over wage increases for workers, where in the nature of the controversy there is no "right" answer.

\section{H. Government Information}

If access is to be fruitful, we must greatly increase the flow of government information. Where a citizen challenges a denial of a benefit, the government department must provide him in advance of his appeal hearing with a full statement of the facts as found by the deciding official, his reasons, his submission why his decision was right, and full citation of the regulations and previous decisions which governed his ruling. This happens in the United Kingdom, and successfully. Along with it must go unrestricted access to the governmental departmental libraries which house all these legal sources.

In other matters, the flow of information is inadequate: the internal departmental practices which in fact control the exercise of discretionary powers, or the points system which the subordinate official is instructed to apply in deciding applications for licences or the allocation of scarce resources like municipal housing. When regulations are being drafted to implement legislation, the public must have the opportunity to participate in the ante-natal consultative process. Arguments about confidentiality, inability of civil servants fearlessly and frankly to advise their Ministers, professional ethics, administrative inconvenience, expense, must not be allowed to stand in the way of access to justice for the individual.

One way in which this administrative secrecy is exposed is through the medium of the Ombudsman, since whatever restrictions exist in respect of disclosure of evidence to administrative tribunals, they are inapplicable to him. The citizen's access to him can often pave the way of justice before administrative bodies within the Welfare State. The institution of the Ombudsman, with the opportunity afforded to the citizen of having a public officer uncover for him everything that lies behind an asserted piece of maladministration of which he is the alleged victim, must be seen as an essential concomitant of any acceptable system of accessibility to the judicial system. The history of the Parliamentary Commissioner, as he is known 
in the United Kingdom, demonstrates conclusively that the citizen is given help in his confrontation with the Administration not available to him from any other source.

\section{Programme for Future Action}

What is the programme for future action? In many areas it is purely speculative what will prove to be the best solution for a particular country. We are desperately short of empirical data.

\section{A. Private Practice in Poorer Areas?}

The kind of activity which charitable foundations in the United Kingdom are fostering seems to be commendable. For example, in my home city of Manchester, I am supervising an experiment on behalf of the Nuffield Foundation. It is a subject of much debate whether lawyers in private practice could run a profitable business not in the city commercial centre nor in prosperous suburbs, but in the poorer areas of concentrated low-grade housing. These are areas where the legal work will be largely welfare law, legal work which at the moment is, by and large, simply not done at all within private practices. The question is whether a staple diet of industrial accidents, matrimonial disputes, employment claims, petty crime and landlord and tenant cases, can within the existing legal aid and advice mechanism sustain a specialist private practice in such districts. The Nuffield Foundation is financing such a practice for three years, and extremely detailed monitoring of the practice is being undertaken, with the result that at the end of the trial period the profitability in all legal fields and the extent to which unexplored need has been met, will be assessed with some degree of precision. With this information it will be possible to decide whether there is an alternative (or additional) solution to law centres functioning entirely under the umbrella of some public body which bears total financial responsibility. 


\section{B. Experimentation and Diversity}

I do not believe that there is any one way of achieving maximum access in the Welfare State. Many different reforms are needed, all directed to the same end. In the volumes of the Florence Access-toJustice Project Series, which we have read in preparation for this Colloquium, theoretical justification for many various solutions is advanced. No logical process is going to prove what is best for any one country. What we need is practical experimentation. We need to select those proposals which carry the most conviction and then set them up in the most favourable conditions. They need monitoring so as to assess their merits.

I would hope that attention will be focussed on this aspect. We should consider which proposals merit experimentation, but, above all, what means can be utilised of assessing their merits. By what criteria are they to be measured? What form of monitoring is efficient? What categories of persons can best monitor? Where might funds be sought for this?

The call is for diversity of methods. Ideally, within a particular country the most favourable conditions for each of various competing solutions should be established in the hope that conclusions about the efficiency and justice of the respective adopted techniques can be drawn.

I believe that the next stop in this search for the best means of providing access to justice should be to try out the most promising solutions in the real world of disputes and controversies within the Welfare State. 



\section{THE QUEST FOR JUSTICE}

by

ANDRÉ TUNC

Professor of Law, University of Paris I

At the outset, this reporter should confess that he has found it extremely difficult to deal with the topic "Access to the Legal System and the Modern Welfare State." In part this difficulty may be due to his own limitations, but it is also due to the breadth of the subject matter. It is nearly impossible to open a legal periodical without finding some relevant article or case. ${ }^{1}$ It is even impossible to read the daily newspaper without having the same experience. As the welfare state is omnipresent, similarly, the problem of access to the legal system in the welfare state is omnipresent. Trying to present it in all its aspects is to prepare a sort of indigestible pudding.

This reporter should additionally confess that since his paper was prepared for presentation at the conclusion of the Florence Colloquium (which itself represents the fruit of impressive and valuable research conducted under the leadership of Professor Mauro Cappelletti), he felt entitled to expand even further his approach to the subject matter. Before dealing with those problems of access to the legal system that are specific to the welfare state, he would like to take a look at the present situation as regards the vindication of traditional rights (those of a spouse, buyer, owner, etc.). And, after having more specifically considered the general subject matter, he would like to ask himself to what extent we have realized "Justice" (with a capital "J") and the goals of the welfare state. Thus, this report will be divided into three parts, respectively dealing with:

1 The January 1979 issue of the Harvard Law REview (Vol. 92), for instance, contains articles dealing with access to justice starting on pages $547,610,664,718,745$ and 757 . 
- access to legal justice,

- access to the machinery of justice specific to the welfare state, and

- access to "Justice."

Before beginning with the first part, however, we should briefly consider a preliminary question. Why is it that in a colloquium concluding the Access-to-Justice Project, the expression "Access to the Legal System" was used in the title of the final session? I assume that the word "justice" was set aside as too closely associated with court structure. In a perfect society the citizen would enjoy the benefit of the law (assuming there is still a law...) without recourse to the courts. In our earthly societies, disputes can be settled not only by adjudication, but also by means of negotiation, mediation, arbitration, coercion and avoidance. ${ }^{2}$ Some of these procedures may be illsuited to our particular societies - especially as new procedures may become needed in the welfare state. ${ }^{3}$ But Japan, for instance, demonstrates to us the possible use of conciliation and mediation either in matters where the intervention of courts is difficult or undesirable (e.g., family disputes) or in matters of primarily modern concern (traffic, environmental pollution and consumer protection). While such procedures are traditional in Japan, there is no reason why they should be the monopoly of that country. ${ }^{4}$ The availability and po-

2 See Koch, Access to Justice: An Anthropological Perspective, in Access to Justice: The Anthropological Perspective 1 (Alphen aan den Rijn/Milan, Sijthoff and Noordhoff/Giuffrè, Vol. IV of the Florence Access-to-Justice Project Series, K.-F. Koch ed., 1979); Johnson, Thinking about Access: A Preliminary Typology of Possible Strategies, in Access to Justice: Emerging Issues and Perspectives 3 (Alphen aan den Rijn/Milan, Sijthoff and Noordhoff/Giuffrè, Vol. III of the Florence Access-to-Justice Project Series, M. Cappelletti \& B. Garth eds., 1979); Cappelletti \& Garth, Access to Justice: The Worldwide Movement to Make Rights Effective: A General Report, in Access to Justice: A World SURvey 3, 59-66 (Alphen aan den Rijn/Milan, Sijthoff and Noordhoff/Giuffrè, Vol. I of the Florence Access-to-Justice Project Series, M. Cappelletti \& B. Garth eds., 1978). See also Access to Iustice: Promising Institutions 37-427 (Alphen aan den Rijn/Milan, Sijthoff and Noordhoff/Giuffrè, Vol. II of the Florence Access-to-Justice Project Series, M. Cappelletti \& J. Weisner eds., 1978/1979).

3 See Cappelletti \& Garth, supra note 2, at 49-51.

4 This point was underlined by the Japanese national reporters. See Kojima \& Taniguchi, Access to Justice in Japan, in Access TO Justice: A World SuRvey, supra note 2, at 687, 717-34. A Frenchman may be excused for pointing out here that reconciliation of the parties, which aroused such great hopes during the French Revolution, only to give rise to equal disappointment, has recently been revived in France after successful experimentation. See Cappelletti \& Garth, supra note 2, at 62; Thery, Access to Justice in France, in Access To Justice: A World Survey, supra note 2, at 479, 509-11, 521-22; Bonnet, Du suppléant du juge de paix au conciliateur, [1979] JURIS-ClasseUr PÉRIODIQUe I. 2949. For a world survey of promising institutions, many of them with conciliatory or mediatory tasks, see Johnson, Promising Institu- 
tential usefulness of such alternatives probably explains why the expression "Access to the Legal System" was chosen. For the sake of simplicity, however, I shall uniformly speak here of "access to justice."

The conclusion of this report will be that much has been accomplished, even if much still remains to be done, for access to the enforcement of traditional rights; that access to the administrative and social machinery of justice leaves much more to be desired; and that, unfortunately, access to "Justice" remains somewhat of a mockery. If "nothing must be left undone," to adopt Lord Denning's admonishment, ${ }^{5}$ we, lawyers, have still very much to do.

\section{Access to Legal Justice}

The concept of "legal justice" is not entirely clear. What I wish to consider here is the enforcement of traditional rights, whether "private rights" (i.e., the rights of a creditor, owner, tenant, parent, spouse, etc.) or the right of an accused person not to be deprived of his life, liberty or property without due process of law.

\section{A. Financial Barriers}

Two specific reports for this Colloquium have already been devoted to the main aspect of this subject, an aspect to which the Project's General Reporters previously paid much attention: the access of the poor to legal services. ${ }^{6}$ I may perhaps remind you, however, that whatever efforts have been made to ensure equal access to courts and legal services for all persons, equality is still very far from achieved. ${ }^{7}$ Despite our efforts, poor persons or persons of modest

tions: A Synthesis Essay, in Access to Justice: Promising Institutions, supra note 2, at 869, 882-900.

5 Lord Denning, The Discipline of Law 315 (London, Butterworths, 1979).

6 Cappelletti \& Garth, supra note 2, at 22-35. See also B. Garth, Neighborhood Law Firms for the Poor: A Comparative Study of Recent Developments in Legal Aid AND IN the Legal Profession (Alphen aan den Rijn, Sijthoff and Noordhoff, 1980).

7 See Johnson, supra note 4, at 876-78. See also the striking table by Galanter of the advantages of institutional litigants over poor litigants, reproduced by Johnson, supra note 2, at 18. In an address to the Los Angeles Bar Association on May 4, 1978, President Carter denounced the U.S. legal profession, saying that it has too often protected the "hierarchy privilege" and "accommodated the interests of the public... only when forced to." Finding 
means often do not even think of trying to enforce their rights or, if they do, are severely handicapped in the legal process. After an accident, a poor or aged person will easily accept a settlement offered by an insurance company, unfair as it may be. The best we can do is to release him from an abusive settlement. When in a slum a wife is abandoned by her husband, she will often fail to seek either a divorce or support for herself and her children: the husband has disappeared and would be unable to pay anything anyway. ${ }^{8}$ Her first concern, therefore, is to try to earn her living without wasting any time on legal proceedings. But the result is frequently that she is deprived of the possibility of remarriage. I also know of a case where the plaintiff was assisted by a young lawyer who had been assigned to him without pay under the old legal assistance scheme, while the defendant, a powerful corporation, had retained one of the foremost members of the Paris bar and, additionally - the principle at issue being one of great importance for it - had secured legal opinions from seven law professors. ${ }^{9}$ And, finally, it is still far too easy for a person with little education to make damaging statements or give a jury a wrong or bad impression - which may eventually even cost him his life. ${ }^{10}$

When legal services are very costly, access to the courts may be a problem not only for the poor but also for the rich, which is the case in England and the United States. In the United States many settlements which are reached between corporations or between a corporation and a government agency are considered unfair by one of the parties, but are nevertheless accepted in order to avoid long and costly litigation. ${ }^{11}$

that " $90 \%$ of our lawyers serve $10 \%$ of our people," he declared: "No resource of talent and training in our society, not even medical care, is more wastefully or unfairly distributed than legal skills."

As regards the situation in France, see also Laroche de Roussane, Valetas \& Boigeol, L'aide judiciaire et l'exercice du droit à la justice, 1978 L'ANNÉE SOcIOlOgIQUe 223 et seq.

On "party capability," see Cappelletti \& Garth, supra note 2, at 14-18.

For a plea in favor of contingent fees, see White, Contingent Fees: A Supplement to Legal Aid, 41 Modern Law Review 286 (1978).

8 ANALYSE PAR APPROCHE SOCIO-DEMOgRAPHIQUe ET ECONOMIQUe DE LA PENSION alimentaire en CAS De Divorce (Paris, Editions du Centre National de la Recherche Scientifique, A. Mazel ed., 1978).

9 See Johnson, supra note 4 , at 879.

10 See G. Perreault, Le pull over rouge (Paris, Ramsay, 1978).

11 See Soloman, A Businesslike Way to Resolve Legal Disputes, Fortune, February 26, 1979 , at 80 . In order to finance a lawsuit, a New York lawyer has even made a public offering of shares in the proceeds from the suit. International Herald Tribune, April 26, 1978. 
Access to the courts for enforcement of the law may even be a problem for the government. A few years ago, two large American computer corporations settled an anti-trust suit. Over the course of two years, they had exchanged an average of 10,000 documents per day. The plaintiff had been working in cooperation with the Department of Justice. Part of the settlement was that the keys to the documents would immediately be destroyed. The Department of Justice was thus left with a huge stock of paper it could not use alone. It was practically powerless to consider whether a breach of antitrust legislation had occurred.

This may seem to be an isolated case. But it is certainly a common situation that the American Department of Justice or some other government agency in the United States or elsewhere does not have the staff and financial resources required for the enforcement of the law. It is even a traditional philosophy of the common law and of American economic legislation that enforcement should result from the cooperation of public authorities with private citizens, the latter being granted as large a role as possible. ${ }^{12}$

Even such a powerful and feared institution as the Securities and Exchange Commission largely relies on private persons for the enforcement of securities regulations. ${ }^{13}$ This "private attorney general approach" has been followed in many countries, especially in France, by an "organizational private attorney general approach," to which the Project's General Reporters have already paid much attention ${ }^{14}$ and which seems very promising. No system is perfect,

12 See Cappelletti, in M. Cappelletti \& J. Jolowicz, Public Interest Parties and the Active Role of the Judge 100-53 (Milan/Dobbs Ferry, Giuffrè/Oceana, 1975); Cappelletti, Governmental and Private Advocates for the Public Interest in Civil Litigation: A Comparative Study, in Access to Justice: Promising Institutions, supra note 2, at 767; Cappelletti, Vindicating the Public Interest through the Courts: A Comparativist's Contribution, in Access to Justice: Emerging Issues and Perspectives, supra note 2, at 513, 533-37; Tanaka \& Takeuchi, Role of Private Persons in the Enforcement of Law, 7 Law IN JAPAN 34 (1974), reproduced in H. Tanaka (assisted by M. Smith), The Japanese Legal System 331 (Tokyo, University of Tokyo Press, 1976).

13 Among many other studies, see Stevenson, Le Procureur général privé dans le droit des societés des Etats-Unis, 1978 REVUE INTERNATIONALE DE DROIT COMPARÉ 779. See also Smit, La procédure civile comme instrument de réforme sociale, 1976 REVUE INTERNATIONALE DE DROIT COMPARÉ 449.

14 Cappelletti \& Garth, supra note 2, at 40-48. See also M. CAPpelletti \& J. Jolowicz, supra note 12; Cappelletti, supra note 12. For France, see Thery, supra note 4, at 520-21.

In France, the associations which have access to courts (see infra at note 52) have recently had recognized the right to legal aid for the exercise of their action. Decision of the Bureau supérieur d'aide judiciaire of June 14, 1978, [1979] RecueIl Dalloz Sirey, Jurisprudence 203, with note by Laroche de Roussane. 
however. In the United States, for instance, the investor may be trapped between this legislative and administrative policy and the recent policy of the Supreme Court, which has been to subject class actions to expensive procedural requirements, ${ }^{15}$ to reduce the field of implied private rights of action under federal regulatory statutes ${ }^{16}$ and to subject such actions to new requirements. ${ }^{17}$

\section{B. Knowledge of Rights and of Cause of Action}

Access to legal justice would also require that the aggrieved citizen knows that his rights have been violated and that he has a cause of action. Quite often, unfortunately, this is not the case. Unnecessary surgery, for instance, is not only dishonest, but an impairment of physical integrity and the creation of a danger to life. Still, in the United States, the Department of Health, Education and Welfare considers that as many as one third of the 20 million non-emergency surgeries performed each year are not necessary. A Congressional sub-committee was more modest in its estimate, but still declared that about two million unnecessary operations had been performed in 1977 , costing more than two billion U.S. dollars and resulting in the death of more than 10,000 persons. Reflection on the damages which deserve compensation and still remain uncompensated reveals a very striking and unfortunate picture. ${ }^{18}$

\section{Small Claims}

Whether rich or poor, the citizen will not claim redress for the denial of his rights if the injury done to his interests has been a

15 Eisen v. Carlisle and Jacquelin, 417 U. S. 156 (1974). See Block \& Watson, New Battles in the Class Struggle - The Federal Courts Reexamine the Securities Class Action, 34 Business LAWYER 455 (1979).

16 Cort v. Ash, 422 U. S. 66 (1975); Piper v. Chris-Craft Industries, Inc., 430 U. S. 1, $37-41$ (1977); Santa-Fe Industries, Inc. v. Green, 430 U. S. 462 (1977).

17 Blue Chip Stamps v. Manor Drug Stores, 421 U. S. 723 (1975); Ernst and Ernst v. Hochfelder, 425 U. S. 185 (1976).

18 See, e.g., Tunc, Introduction to Vol. XI (Torts) of the InTERnATIONAL Encyclopedia of Comparative Law, at sec. 127 (Tübingen/The Hague and Paris/New York, Mohr/Mouton/Oceana); Righting the Liability Balance: Report of the California Citizens' Commission on TORT Reform 8 (Los Angeles, 1977); Tunc, Le spectre de la responsabilité civile, 1978 REVUe INTERNATIONALE DE DROIT COMPARÉ 1032 et seq. 
minor one. This, again, is a point to which the Project's General Reporters have paid much attention ${ }^{19}$ and on which little could be added.

\section{Diffuse and Fragmented Interests}

Similarly, little can be added to the reports for the second session of the Colloquium on the protection of diffuse and fragmented interests or to what the Project's General Reporters have written also on this question. ${ }^{20}$ It may be interesting, however, to note that shareholders' derivative actions have been recognized for a long time in the United States, notwithstanding their dangers and possible abuses, and that the English Court of Appeal has decided in Wallersteiner $v$. Moir (No. 2) ${ }^{21}$ that courts may by a preliminary order compel a company to indemnify the plaintiff for the costs incurred in a minority shareholder's action if the action is brought in good faith and appears reasonable and prudent in light of the company's interest.

The protection of diffuse and fragmented interests - and of the public interest in general ${ }^{22}$ - is unfortunately still very far from achieved. Consumer protection, in particular, is a field where a vast amount of legislation and regulation, as well as numerous agencies, presently exist in most industrialized countries, but where the statutes and regulations are continuously being violated. ${ }^{23}$ Consumers often ignore the fact that they may be entitled to a remedy for their misfortunes; consumer associations

19 Cappelletti \& Garth, supra note 2, at 69-84. See also Access to Justice: Promising Institutions, supra note 2, at 489-763 (Part Four: Small Claims and Consumer Problems).

20 Cappelletti \& Garth, supra note 2, at 18-20, 35-40, 90-99. See also Cappelletti, La protection d'intérêts collectifs et de groupe dans le procès civil, 1975 REVUE INTERNATIONAL DE DROIT COMPARÉ 571 et seq.; M. CAPPELletTI \& J. Jolowicz, supra note 12, at 5-153; Cappelletti, supra note 12; Fisch, European Analogues to the Class Action: Group Action in France and Germany, 27 American Journal of Comparative Law 51 (1979).

21 [1975] 1 Q. B. 373, [1975] 1 All E. R. 849. note 12 .

22 See Cappelletti, in M. Cappelletri \& J. Jolowicz supra note 12; Cappelletti, supra

${ }^{23}$ Sweden might be the country where consumer protection is most effective, without, of course, being fully satisfactory. See Eisenstein, The Swedish Public Complaints Board: Its Vital Role in a System of Consumer Protection, in Access to Justice: Promising Institutions, supra note 2, at 491; Hellner, The Consumer's Access to Justice in Sweden, 40 Rabels ZeITSCHRIfT 727 (1976), teproduced in JulSKRIFT 1978 fRAN JAN Hellner 71-95 (Stockholm, 1979). 
are under the constant danger of committing a defamation when they issue reports; and their standing to sue is often subject to challenge. ${ }^{24}$ In the United States, public interest law firms have encountered great difficulties. ${ }^{25}$ In France, an official organization, the Institut National de la Consommation, and a consumer association, the Union Fédérale des Consommateurs, issue the monthly bulletins 50 millions de Consommateurs and Que Choisir? Reading them is a depressing experience. ${ }^{26}$ The bulletins sometimes point to abuses which are made possible by insufficient regulation. But every month, they also give evidence of continuous breaches of existing regulations. The reader discovers that he is constantly cheated, on a large scale and without any possible remedy, with regard to prices, quality and quantity. Besides being cheated, he may also be poisoned. I shall quote only one example: the March issue of Que Choisir? reveals in its first article that the actual weight of meat was inferior to that stated on the label in 49 cases out of 54, thus causing an average overcharge of the consumer of 2.4. percent. Moreover, 29 pieces of meat out of 80 did not meet the freshness standards fixed by regulation. One could wish that such abuses were to be found only in France, but, alas, it is very likely that they also exist

24 See Cappelletti, Vindicating, supra note 12, at 517. On March 15, 1979, a U.S. District Court ruled that consumer organizations founded and run by Ralph Nader have no legal right to file suits on behalf of the public. Implicitly criticizing Mr. Nader's one-man rule over the consumer groups he heads, Judge Sirica said that a democratically organized group, with duespaying members and elected officers, would have a legitimate right to sue on behalf of its members, representing the public. But, Judge Sirica noted, the Nader groups involved in the case have no dues-paying members and no elected officers. International Herald Tribune, March 16, 1979.

On the other hand, on May 30, 1978, the Supreme Court ruled that states may discipline lawyers for personally seeking out clients for private gains, but not for offering free advice on behalf of non-profit organizations with political goals. Dividing 7 to 1 , it overruled a decision of the South Carolina Bar to issue a private reprimand to a lawyer for the American Civil Liberties Union who had written to a potential client inviting her to join a suit against a doctor who had sterilized her and other welfare mothers. International Herald Tribune, June 1, 1978.

25 See Handler, Public Interest Law Firms in the United States, in ACcess to Justice: Emerging Issues and Perspectives, supra note 2, at 421; D. Trubek, L. Trubek \& J. Becker, Legal Services and the Administrative State: From Public Interest Law to Public Advocacy (mimeo, 1978).

26 Reading the daily newspaper may also be a depressing experience. The International Herald Tribune of May 9, 1979, reports on a survey conducted by the U.S. Department of Transportation: "The survey showed that more than half of the $\$ 50$ billion U.S. customers spend every year on car repair - 53 cents of each dollar - goes for needless work. The biggest problem... is engine repair, where it is 'almost a sure thing' that the work will not be done properly." 
elsewhere. Nor are they limited to supermarkets; the small family butcher is probably worse.

Such abuses, as well as many cases of misleading advertising, leave the individual victim of the dishonesty without any real remedy. Class actions are not practicable, and actions by consumer associations, when available, normally have only a punitive and hopefully - preventive effect. Even the modern and less formal mechanisms of consumer protection ${ }^{27}$ cannot bring relief. What then are the remedies for society at large? Probably still more regulations, more controls and controllers, and heavier sanctions. But there are obvious limits to such remedies. Stress should be laid on informing the public of such abuses, ${ }^{28}$ but French consumer associations are harassed with defamation actions, and French national television allocates three hours and forty minutes a week to advertisers and only twelve minutes to consumer associations: the fight is not an equal one.

\section{E. Specialized Courts}

The General Reporters have already shown the importance of specialized courts for the protection of traditional rights. ${ }^{29}$ In this connection, labor law deserves our particular attention because of its importance and because it, more than any other area of the law, seems to require such courts. ${ }^{30}$ Even though especially in this field "official law" is only one element in a complex of social practices, ${ }^{31}$ access to the legal system is very important to the employee because his social and economic position is greatly inferior to that of the employer. It is also important to the employer, since his power may be overshadowed by that of the workers' unions.

The French courts entrusted with the settlement of individual disputes between employees and employers - the conseils de prud'bommes ${ }^{32}$ - may be taken as a model. They are composed of

27 See Cappelletti \& Garth, supra note 2, at 90-99; Access to Justice: Promising InSTITUTIONS, supra note 2 , at 489-763.

28 See Cappelletti \& Garth, supra note 2, at 90-91.

29 Cappelletti \& Garth, supra note 2, at 66-69.

30 See M. Cappelletti, Giustizia e società (Milan, Editori di Comunità, 1972).

31 See Javillier, Droit du travail et sociologie, 1978 L'ANNÉE sociologiQue 117 et seq.

32 G. Camerlynck \& G. Lyon-Caen, Droit du travail, at Nos. 752 et seq. (Paris, Dalloz, 9th ed., 1978); La juridiction du travail en France, 1974 DroIT social (special issue, 
an equal number of representatives of management and labor, ${ }^{33}$ and the Chairman is alternately an employee or an employer. If there is an equal division of votes, a professional magistrate, a juge d'instance, is called upon to cast the deciding vote. As our General Reporters have requested, ${ }^{34}$ the procedure of these labor courts is simple and inexpensive. It starts with an attempt to reconcile the parties, who come in person and may be assisted by a lawyer or a union representative. If the "bureau de conciliation" fails to help the parties reach an agreement, the case will be settled by the "bureau de jugement," subject to appeal to the appropriate cour d'appel and to the further control of the Cour de Cassation.

France thus seems to have solved many of the problems of access in the area of labor law. Unfortunately, this solution is still far from perfect. ${ }^{35}$ First, the conseil de 'prud'bommes' jurisdiction does not extend to all labor disputes, not even to all individual ones. Civil servants and employees of the state or regional entities have no access to the conseil and must apply to the normal administrative courts. Administrative courts also have jurisdiction - a jurisdiction of increasing importance - over some dismissals directly controlled by the administration. Some other disputes must be submitted to the normal civil court, the tribunal de grande instance, or even to the emergency court, the juge des référés. The criminal courts may also have to interfere in a dispute. Secondly, research has shown that in 95 percent of the cases, the plaintiff is an employee. In other words, employers do not initiate proceedings before the conseil, either because they do not trust it or because they use "self-justice" and simply dismiss the employees with whom they have a dispute, leaving it to them to apply to the conseil. This is obviously a disturbing finding. Thirdly, the conseil usually receives a case after the labor relationship has already been broken by one of the parties: it never

G. Lyon-Caen ed., February 1974). However, account should be taken of Statute No. $79-44$ of January 18,1979 , amending the previous legislation. On this 1979 statute, see Alibert, La loi $n^{\circ}$ 79-44 du 18 janvier 1979 sur le conseil des prud'bommes, [1979] Recueil Dalloz Sirey, Chronique 169; Napier, The French Labour Courts: An Institution in Transition, 42 Modern LAw REview 270 (1979).

33 On lay justice, see Friedman, Access to Justice: Social and Historical Context, in Access to Justice: Promising Institutions, supra note 2 , at 3, 22-28.

34 Cappelletti \& Garth, supra note 2, at 69.

35 See Gaudillière, En droit du travail: Absence de recours judiciaire?, 1972 PROJET 603 et seq.; La juridiction du travail en France, supra note 32; Champenois-Marmier, Les conseils de prud'bommes: cadres juridiques et cadres sociaux et leur fonctionnement, 1978 L'ANNÉE SOCIOLOGIQUE 143 et seq. 
settles easy disputes. This fact, however, is ambiguous: it may also reveal a successful settlement of grievances by mere agreement between the parties on the basis of the report of the employee's delegate - which would also explain why the conseil is used mainly by employees who do not belong to a union. Finally, notwithstanding the measures taken to simplify the procedure and to make it speedy and inexpensive, some employees may still find that too much trouble is involved in return for an uncertain and delayed result. ${ }^{36}$

Even though the conseils de prud'bommes are not the labor courts of our dreams, assuring to all workers and employers the enforcement of labor law, they certainly constitute a valuable institution. ${ }^{37}$ A statute passed by Parliament in January 1979 should improve their functioning. A bolder proposal with respect to labor law disputes will be considered in the second part of this report. That proposal would have the advantage of including jurisdiction over collective disputes, which are not dealt with in this report but which are increasingly intermingled with individual disputes.

Before concluding this part of the report and moving on to the part more specific to the welfare state, a few additional points should be mentioned.

\section{F. Uncertainty of the Law}

First of all, access to legal justice is a fallacy when the law is highly uncertain. The plaintiff then reaches for something that may not exist. ${ }^{38}$ This reporter has written earlier: "In the field of traffic accidents, the law no longer exists.... No one can guess the outcome of a law suit." 39 In this field, and probably also in the field of medical accidents, access to justice would mean automatic compensation. ${ }^{40}$ Unfortunately, compensation for traffic and medical accidents

36 The institution has a number of additional weaknesses which are not so directly connected with access to justice. Failure to vote in elections reached a very high level before the elections following the 1979 reform. Only the candidates nominated by the most representative unions have a real chance to be elected.

37 On the 1973 Italian labor reform, see Cappelletti \& Garth, supra note 2, at 106-07.

38 There is even a law book by T. Ison which is entitled THE Forensic LotTery (London, Staples, 1967).

39 Tunc, Un bilan provisoire, 1967 DroIt Social 71, 73.

40 Cappelletti \& Garth, supra note 2, at 118-19. On the larger issue of the "routinization" of the law, see Friedman, supra note 33, at 16-21. 
does not stand alone as regards uncertainty. ${ }^{41}$ The development in the United States of civil liability based on SEC Rule 10b-5 has led to a number of unpleasant surprises for citizens who were not conscious of breaking any law. The complexity of antitrust law and of patent, trademark and copyright law is a nightmare for businessmen. One sympathizes with the businessman who, asked what he expects from his lawyer, answers: "I would like to know whether the chances of going to jail are $50-50$ or $70-30$ or $10-90$." 42

\section{G. Unsatisfactory Laws}

Similarly, access to legal justice is also somewhat of a fallacy when the law is unsatisfactory. ${ }^{43}$ Efforts to improve access to the law cannot be divorced from efforts to improve the law itself. This is what explains the movement toward public interest law firms and, more recently, public advocacy. ${ }^{44}$

\section{H. Prospective Overruling}

Access to legal justice becomes a complete mockery when the law is changed without any transitional period, thus causing the plaintiff to lose an action which he was entitled to win when it was introduced. This raises the issue of prospective overrulings, practiced to a certain extent in the United States and at least discussed in England. ${ }^{45}$

41 During the preparation of this report, I was told by a car dealer, presently claiming damages from a car-maker for cancellation of his franchise: "I shall not receive the money for at least three years: one for the decision of the first instance, two others for the decision of the court of appeals." The law is so uncertain that the parties feel that a case must be settled only on appeal.

42 Frey, in A Businessman's View of Lawyers, 33 Business Lawyer 817, 819 (1978). See Vogts, Legal Opinions in Quantitative Terms: The Lawyer as Haruspex or Bookie, 34 Business LAWYER 421 (1979).

43 See L. Weinreb, Denial of Justice: Criminal Process in the United States (New York, Free Press, 1977); Calabresi, Access to Justice and Substantive Law Reform: Legal Aid for the Lower Middle Class, in Access to Justice: Emerging Issues and Perspectives, supra note 2 , at 169 .

44 See Handler, supra note 25; D. Trubek, L. Trubek \& J. Becker, supra note 25; Trubek, Public Advocacy: Administrative Government and the Representation of Diffuse Interests, in AcCess to Justice: Emerging Issues and Perspectives, supra note 2, at 445.

45 See Lord Diplock, The Courts as Legislators, in THE LAwYeR AND Justice 263, 280-82 (London, Sweet \& Maxwell, B. Harvey ed., 1978); R. Keeton, Venturing to Do 


\section{Psychological Costs}

Access to legal justice is also denied if its psychological cost is too high. This has traditionally been the case in Asia, especially in Japan. Social duties towards superiors, inferiors or equals made it shocking for centuries to resort to the machinery of justice. This attitude survived the industrialization of the country, preventing victims of traffic accidents or pollution from receiving adequate compensation. The situation is now rapidly evolving. It would be surprising, however, if all remnants of the old inhibitions had disappeared. ${ }^{46}$

The psychological cost of a lawsuit is still currently too high all over the world for the poor, for the uneducated and for foreign workers, etc. ${ }^{47}$ Such a cost may also result from the nature of the complaint to be made to the authorities: in many countries rape victims often refuse to report the crime, mainly because they fear the treatment they might receive from the police, prosecutors or defense attorneys. A study of the American Law Enforcement Assistance Administration reveals that four rapes out of five remain unreported, that every fourth complaint results in an arrest and only one out of sixty in a conviction. ${ }^{48}$

Justice 25-53 (Cambridge, Harvard University Press, 1969); Nicol, Prospective Overruling: A New Device for English Courts?, 39 Modern Law Review 542 (1976), and the works cited therein; R. Cross, Precedent in English Law 229-33 (Oxford, Clarendon Press, 3rd ed., 1977); M. Cappelletti \& W. Cohen, Comparative Constitutional Law: CASES AND MATERials 105-12 (Indianapolis, New York \& Charlottesville, Bobbs-Merrill, 1979).

46 See Y. Noda, Introduction au droit japonais 173 (Paris, Dalloz, 1966); Y. Noda, An Introduction to Japanese Law xii-xiv, 157 (Tokyo, University of Tokyo Press, A. Angelo ed. and transl., 1976); H. TANAKA, supra note 12, at 254; Kojima \& Taniguchi, supra note 4, at 693, 711, 718; R. DAvID, LES GRANDS SYSTÈMES DE DROIT CONTEMPORAINS, at Nos. 494-502 (Paris, Dalloz, 7th ed., 1978); R. David \& J. Brierley, Major Legal. SysTEMS IN THE World Today, at secs. $494-502$ (London, Stevens \& Sons, 2nd ed., 1978); K. Zweigert \& H. Kötz, Vol. 1 (The Framework) of An Introduction to Comparative LAw 362-65 (Amsterdam, North Holland, L. Weir transl., 1977); Kawashima, Disprite Resolution in Contemporary Japan, in LAw IN JaPaN 41 (Cambridge, Harvard University Press, A. von Mehren ed., 1963).

47 See Johnson, supra note 4, at 887-78; Johnson, supra note 2, at 10-11.

48 International Herald Tribune, August 8, 1978. Compare International Herald Tribune, September 5, 1978 


\section{J. Witnesses}

Of course, access to justice is diminished if the plaintiff cannot obtain witnesses. Selfishness and fear on the part of witnesses prevent many victims from obtaining justice. In the United States, the National District Attorneys Association has sponsored victim-witness assistance programs. The Department of Justice embarked in 1970 on a Witness Security Program. Other groups have made comparable efforts - but with seemingly only modest results.

\section{K. Slowness}

Access to justice also loses a great deal of its interest if the machinery of justice is too slow. Unfortunately, this is the case in many countries. 49

In this regard, I wish to emphasize the value of two institutions which may have been born in France, and for which, in any case, French law appears to be typical: the juge des référés, who can order without delay the undertaking of temporary measures to protect the interests of a party, ${ }^{50}$ and the action civile. ${ }^{51}$ Whenever someone is prosecuted before a criminal court, the persons who have suffered from the crime may by means of an action civile intervene in the court and ask for damages. This is a very fast and inexpensive procedure. What is more, the victim of a crime may himself summon its perpetrator to appear before the criminal court or, if the case is important and needs to be prepared by a juge d'instruction, he may file

49 See, e.g., decision of the Cour de Cassation of November 3, 1977, [1978] RecueIL Dalloz Sirey, Jurisprudence 434, with note by Caballero: a dispute concerning new construction started in 1962; fifteen years later, the decision of the court of appeals which might have settled the matter was quashed and the case remanded to another court of appeals. In another field of law, see, e.g., decision of the Conseil d'Etat of October 13, 1978 (A.D.A.S.E.A.), [1979] Recueil Dalloz Sirey, Jurisprudence 249, with note by Amselek \& Waline: having received incorrect information from an administrative agency, a citizen seeks to have the agency declared liable; nine years later, the Conseil d'Etat cancels the decision which had finally granted him compensation and he is ordered to pay the costs of the whole procedure and advised to try his luck before the judicial courts.

50 See Thery, supra note 4, at 487-89; J. Vincent, Procedure civile, at Nos. 243, 263-2, 484-1, 635 bis (Paris, Dalloz, 19th ed., 1978).

51 See Jolowicz, Procedural Questions (Chapter 13) in Vol. XI (Torts) of the INTERnational Encyclopedia of Comparative Law, at secs. 5-40 (Tübingen/The Hague and Paris/New York, Mohr/Mouton/Oceana, 1972); G. Stefani \& G. Levasseur, Procedure PENale, at Nos. 144-227.8 (Paris, Dalloz, 10th ed., 1977); Fisch, supra note 20, at 60-62. 
a complaint with the latter, who is bound to look into the case and take a preliminary decision on it: either to close the instruction or to send the case to court. Recent legislation has opened the door for use of an action civile by a number of associations. ${ }^{52}$

\section{Jurisdictional Clarity}

Access to legal justice also implies that the plaintiff can readily ascertain the court to which he should address his complaint. Uncertainty of jurisdiction or venue is as unfortunate as uncertainty of the substantive law and is particularly irritating to litigants. In many countries, a significant number of cases concerning jurisdiction and venue make their way to the supreme court, thus allowing the plaintiff to learn only after six or seven years of litigation to which court he should turn. This has rightly been called a "parasitic litigation." 53

\section{Conclusion}

To make a long story short, one would wish that access to legal justice would bring satisfaction to law-abiding persons - but there is a widespread dissatisfaction with lawyers, the administration of justice and the law, ${ }^{54}$ a dissatisfaction which accounts for the increased

52 See Thery, supra note 4, at 520-21; supra note 14; G. Stefani \& G. Levasseur, supra note 51, at Nos. 155-70, especially Nos. 160 and 162. See also Salingardes, L'action civile des groupes de consommateurs, in ETUDES OFFERTES AU PROFESSEUR EMÉRENTIENNE DE LAGRANGE 181 (Paris, Librairie générale de droit et de jurisprudence, 1978); Fisch, supra note 20, at 62-71. Compare Cappelletti, Vindicating supra note 12 , at 536-38.

53 See Thery, supra note 4, at 483. See also Cappelletti \& Garth, supra note 2, at 123.

54 See Bellet, Justice civile et désaffectation des justiciables, 1972 PROJET 590 et seq.; J. S. Auerbach, Unequal Justice: Lawyers and Social Change in Modern America (New York, Oxford University Press, 1976). All over the world, research has evidenced this dissatisfaction.

In his article, Mr. Pierre Bellet, who was then Président du Tribunal de Grande Instance de Paris and is now Premier Président de la Cour de Cassation, sees as the main reasons for this dissatisfaction: the duration of a lawsuit, its cost, its formalistic and esoteric character and its inefficiency (difficulty in obtaining the assistance of witnesses and experts and of being certain of a prompt compliance of the other party with the decision of the court).

The Union Fédérale des Consommateurs, previously mentioned, lists in its February 1979 issue seven obstacles standing between justice and the ordinary citizen: 1) the volume of legislation and the number of reforms (see Part II infra), 2) the obscurity of the legal language, 3) the rigid, formal and archaic style of trials, 4) the complexity of the rules concerning juris- 
importance of arbitration, notwithstanding its drawbacks. ${ }^{55}$ As a conclusion to these remarks, let us recall the obvious: the best way of assuring access to justice is to avoid injustices, rather than redress them after they have occurred. That goal may be achieved by organizing diffuse interests so as to give them bargaining power or by setting up institutions which will help them - a policy comparable to the one of participation in the decision-making process adopted a long time ago in Germany for the avoidance of industrial conflicts. Thus, in a number of countries, institutions have recently been created for the promotion of agreements between consumer organizations and producers. Such promotion will be one of the tasks of the new French Commission des Clauses Abusives. ${ }^{56}$ But at this

diction and venue (see above), 5) the delays of justice (see above), 6) the costs of justice (see above), and 7) the inequalities of justice which, volens nolens, favor the powerful.

See also Lord Justice James, Law in Our Time, in The Lawyer and Justice, supra note 45 , at 161 .

See finally an address by Judge Carl Mc Gowan, of the U. S. Court of Appeals for the District of Columbia Circuit, to the entering students of the University of Chicago Law School on October 5, 1978:

$[\mathrm{M}]$ any thoughtful lawyers and judges are beginning to wonder if there are not to be found, in at least some areas of human affairs, better and certainly more expeditious and less costly methods of dispute resolution. The American Bar Association has mounted a major inquiry to this end. Judge Learned Hand long ago observed, after many years of experience as both a trial and an appellate judge, that he could conceive of no greater disaster happening to him as an individual than to become involved in a law suit. And there is quite evident at the moment a rising popular concern, on the part of large corporations as well as less powerful members of the public, with the functioning of our system of justice in its adversary trial aspects.

The University Law School and Practical Education (Occasional Papers from the Law School, The University of Chicago, No. 16).

55 See generally Oppetit, Eléments pour une sociologie de l'arbitrage, 1978 L'ANNÉE SOCIOLOGIQUE 179 et seq.

56 The Commission was created by Loi No. 78-23 of January 10, 1978, sur la protection de l'information des consommateurs de biens et de services, arts. 35 and 36. See Nguyen ThanhBourgeais, Réflexions sur deux innovations de la loi $n^{\circ} 78-23$ du 10 janvier 1978 sur la protection et l'information des consommateurs de biens et de services, [1979] RECUEIL Dalloz SiReY, Chronique 15; Armand-Provost \& Richard, Le contrat destabilisé (De l'autonomie de la volonté au dirigisme contractuel, [1979] JuRIs-CLASSEUR PERIOdIQUe II. 2954. etc.):

See the recommendations of a business adviser to his customers (A.T.T., I.B.M., G.E.,

"Don't wait for the activists to come forward. Go out and meet them at least halfway, and maybe more than that."

At Diebold's sessions corporate chiefs study the successes of other businesses in dealing with publicissiues and outside pressures. They look at the case of the food companies that set up the Food Safety Council, enlisted the help of a ranking aide to Ralph Nader and now mutually work to agree on a list of food products and additives that everybody could consider safe - before going to the great trouble and expense of putting them on the market. Diebold also has his clients study 
point we reach the borderline between traditional rights and the rights created in connection with the welfare state. We now must turn to the latter.

\section{Access to the Machinery of Justice Specific to the Wel- FARE STATE}

\section{A. The Emergence of Social Rights}

"We hold these truths to be self-evident, that all men are created equal, that they are endowed by their Creator with certain inalienable Rights, that among these are Life, Liberty and the pursuit of Happiness." This famous sentence from the American Declaration of Independence was the proud expression of a common belief among 18th Century philosophers, and one based upon a much earlier thought: that government has no power to impair the natural and inalienable rights of citizens. Thirteen years later, the drafters of the 1789 Déclaration des droits de l'bomme et du citoyen went further, making the protection of the natural and inalienable rights of man the very purpose of society: "Le but de toute association politique est la protection des droits naturels et imprescriptibles de l'bomme."

The existence of rights vis-à-vis the government, which had been asserted for centuries in France and England, thus received public and glaring recognition by the end of the 18th Century. A new category of rights had been created, significantly different from the traditional rights inherited from Roman or Anglo-Saxon law. It might be clearer to call them "liberties."

We should note that with the exception of the right to vote, sparingly recognized at that time, these "rights" were basically negative in nature: they consisted solely of limitations placed upon the powers of the state.

the National Coal Policy Project. Companies that mine and use coal formed it with environmental leaders, and together they reached productive compromises to speed the digging and burning of coal. Similarly, Diebold's clients ponder the example of Pennsylvania Power \& Light and Canada's Ontario Hydro. Before building a power plant, they solicit citizen volunteers to examine a number of sites and pick the one that seems the most desirable - and environmentally safest. Perhaps other corporations would be wise to join with real or potential critics instead of fighting them so hard.

Time, April 16, 1979. 
It is obviously not possible here to follow the evolution of political thought over the last two centuries. ${ }^{57}$ If, however, we jump over Bismarck's policy and a large amount of social legislation in all industrialized countries and go directly to Roosevelt's famous "four freedoms" speech in his message to Congress of January 6, 1941, we find not only a declaration of the freedoms of speech and worship, but also of the "freedom from want" and the "freedom from fear." These latter two freedoms imply another conception of the function of the state - a conception already put into practice at that time in the United States by New Deal legislation and, more specifically, by the Social Security Act of 1935. If man is to be freed from want, he must, in some circumstances at least, be freed by the state. The task of the state is no longer only to harmonize the freedoms enjoyed equally by all citizens and to guarantee these freedoms against infringements on its part. The state is expected to take positive action. Positive rights vis-à-vis the government are recognized as belonging to the citizen. ${ }^{58}$ We might call them "social rights."

Three years later, on January 11, 1944, President Roosevelt's annual message to Congress was more specific. It seems worthwhile to quote at some length excerpts from it which enumerate the new rights:

This Republic had its beginning, and grew to its present strength, under the protection of certain inalienable political rights among them the right of free speech, free press, free worship, trial by jury, freedom from unreasonable searches and seizures....

As our nation has grown in size and stature, however... these political rights proved inadequate to assure us equality in the pursuit of happiness.

We have come to a clear realization of the fact that true individual

57 For a sketch of "social history," see J. Fournier \& N. Questiaux, Traite DU soCial: Situations, luttes, politiques, institutions 13 et seq., 443 et seq. (Paris, Dalloz, 2nd ed., 1978); Friedman, supra note 33; P. James, Introduction to ENGLish Law 187-200 (London, Butterworths, 9th ed., 1976). Eighteen centuries B. C., the Hammurabi Code already contained economic and social regulation: it dealt with salaries and the prices of goods. The purpose of the King was "to make justice burst, in order to prevent the powerful from doing injury to the weak."

58 See J. Mourgeon, Les drotTs de L'homme 24 (Paris, Presses universitaires de France, 1978): "Partant d'une volonté réduite à la contestation du pouvoir dans l'intérêt de la personne et de sa préservation, [la revendication des droits] s'est orientée vers la doléance, la réclamation, l'obtention. De résistance au Pouvoir, la revendication est devenue exigence $d u$ Pouvoir, transformant la finalité de ce dernier et, par suite, le rapport politique même. A un effort pour brider, voir ligoter le Pouvoir, a succédé une volonté de l'amplifier en l'obligeant davantage en faveur de la personne." See also id. at 35. 
freedom cannot exist without economic security and independence....

In our day these economic truths have become accepted as selfevident. We have accepted, so to speak, a second Bill of Rights under which a new basis of security and prosperity can be established for all, regardless of station, race or creed.

Among these are:

The right to a useful and remunerative job in the industries or shops or farms or mines of the nation;

The right to earn enough to provide adequate food and clothing and recreation;

The right of every farmer to raise and sell his products at a return which will give him and his family a decent living;

The right of every businessman, large and small, to trade in an atmosphere of freedom from unfair competition and domination by monopolies at home or abroad;

The right of every family to a decent home;

The right to adequate medical care and the opportunity to achieve and enjoy good health;

The right to adequate protection from the economic fears of old age, sickness, accident and unemployment;

The right to a good education.

All of these rights spell security. And after this war is won we must be prepared to move forward, in the implementation of these rights, to new goals of human happiness and well-being.

These new rights are largely contradictory to the traditional ones: they are based on needs rather than on ownership. They are rights granted to the "have-nots" over society, i.e., on the whole, the "haves." 59

B. The Creation of the Welfare State and Problems of Access to Justice

It is a well-known fact that the most extensive and comprehensive efforts to implement such a new Bill of Rights were made in the United Kingdom by Lord Beveridge and the British Government. England became, to a certain extent, the model welfare state. A

59 See Cappelletti \& Garth, Foreword to Access to Justice: Emerging Issues AND Perspectives, supra note 2, at vi-vii. For an account of the efforts made to implement the rights enunciated in 1944 and the results which followed, see J. Duffy, Domestic Afrairs: American Programs and Priorities (New York, Simon \& Schuster, 1978). 
comparable assertion of rights was made in France in the Preamble of the 1946 Constitution, and others may now be found all over the world. The Universal Declaration of Human Rights adopted on December 10, 1948, by the General Assemby of the United Nations proclaims, inter alia, the "right to social security," the "right to work," the "right to rest and leisure," the "right to education," the "right freely to participate in the cultural life of the community, to enjoy the arts and to share in scientific advancement and its benefits." The list will never be complete. The Supreme Court of the United States has a number of times recognized the "right of privacy," and a textwriter has spoken of the "right to nature." 60 The "right to sport" has also been asserted, ${ }^{61}$ and there is certainly a "right to sun." 62 Some of these new rights may have no bearing on the traditional fields of law. In other instances, however, the new concerns of our protective society may invade these traditional fields and interfere with the traditional legal rules: this is happening in the case of employment protection, housing protection, consumer protection and environmental protection.

It seems clear that the problem of access to justice is basically different with respect to these new social rights from what it was for the traditional rights or even for the liberties. The creditor trying to collect $\$ 100.00$ should have access to some machinery through which his debtor would be compelled - subject to some leniency - to pay him this amount. The liberties are further from absoluteness than are private rights. The liberties of each citizen need to be harmonized with the liberties of the other citizens and the security of the whole community. ${ }^{63}$ Such harmonization creates very intricate problems. Still, the citizen should have access to some machinery which will guarantee, for instance, his freedom of expression, even though this freedom is inherently limited.

On the other hand, it is clear that the millions of unemployed citizens in France or in the United States cannot expect to go to

60 J. de Malafosse, Le droit à la nature (Paris, Montchrestien, 1973).

61 P. Mazeaud, Inaugural Lecture of the Chair of Sport Law at the Institut d'Études Politiques of the University of Aix-en-Provence, March 29, 1979 (unpublished).

${ }^{62}$ See generally S. Kraemer, Solar Law (Colorado Springs, Shepard's, 1978); Fournier and Questiaux, supra note 57, cover the following fields: work, family, old age, income redistribution, consumer protection, collective services, education, health, environment, urban renewal and housing, and social life (in a broad sense).

63 See the preface of H. Street, Freedom, the Individual and the Law (Harmondsworth, Penguin Books, 3rd ed., 1972). 
court and force the government to give them a job. The 1977 Soviet Constitution provides that: "the citizens of the U.S.S.R. have a right to housing" (art. 44). This provision, however, does not provide adequate housing for every citizen, not even the right of applying to the court for such adequate housing. The new economic and social rights are not capable of direct enforcement. This is not to say that they are meaningless. The second paragraph of art. 44 of the Soviet Constitution, for instance, gives a more concrete sense to the "right to housing." It consists of: 1) a statement of policy that new constructions will be made or facilitated by the state and social organisms, and 2) the "right to a fair distribution, under social control," of the housing facilities which will result from the implementation of the program. In other words, the "right to housing" is, concretely speaking, the right to have one's name placed on a waiting list and the right to a fair administration of the list. In Western European countries, this right materializes in landlord-tenant legislation, various financial incentives to construction, and sometimes the right to aid from official agencies. Similarly, the right to employment is, on the one hand, embodied in the duty of the government to manage the economy so as to reach the highest possible level of employment and, on the other hand, in a number of specific rights: in France, for example, the right to keep one's job in accordance with the rules of labor law, the right to unemployment compensation, the right to assistance from the Agence Nationale pour l'Emploi, created in 1967, and the right to vocational training (formation professionnelle) pursuant to a 1971 statute.

Thus, social regulations and institutions have developed in all industrialized nations since the end of the Second World War. According to E.E.C. statistics, the social budget of the Federal Republic of Germany amounts to 29 percent of G.N.P., plus 5 percent for its administration. The equivalent figure for France has been estimated to be at the level of 23 percent. ${ }^{64}$

The concern of the welfare state, however, cannot be solely with social matters. A social policy cannot be divorced from an economic policy, as evidenced by the New Deal. If it has the duty of guaranteeing the "right to employment," the state must take the necessary measures to maintain or establish economic prosperity. It also has in

64 E. Alfandari, Aide sociale, action sociale, at No. 9 (Paris, Dalloz, 2nd ed., 1977). For the United States, see infra note 72. 
the economic field the duties, inter alia, of protecting commerce from monopolies and of ensuring the protection of consumers and of the environment. In his pioneering Hamlyn Lectures, Justice in the Welfare State, ${ }^{65}$ Professor Harry Street devoted a chapter to licensing, but underlined that the field of economic regulation was much broader. Even though economic regulation is not something new (in the United States the Interstate Commerce Act of 1887 and the Sherman Act of 1890 are examples of such regulation ${ }^{66}$ ), this field has been recently, and more or less permanently, enlarged. Now, it is everywhere an enormous, multi-faced bulk of legislation administered by numerous departments, bureaus, offices and commissions, many of them with regulatory powers. ${ }^{67}$

The duties of the welfare state are also increased by rising expectations on the part of citizens in the field of liberties. ${ }^{68}$ Let us consider the issue of discrimination, whether discrimination against ethnic minorities or persons of advanced age or the most common form - in this case against a majority - discrimination against women. To prevent discrimination and to give redress to its victims, numerous techniques must be used. The fight against discrimination is entrusted partly to judicial courts, sometimes issuing long-term orders, ${ }^{69}$ partly to traditional governmental administration, and partly to specific commissions and bodies. Still, the fight is never won. Discrimination continuously appears or reappears under various forms and requires new measures. ${ }^{70}$

It is thus clear that the assertion of social rights and the efforts made for their implementation have completely transformed the state. Jefferson's statement that "the government which governs best is the government which governs least" was the expression of a

65 H. Street, Justice in the Welfare State (London, Stevens \& Sons, 1968).

66 See also, for earlier regulations, J. Freedman, Crisis and Legitimacy: The Administrative Process and American Government 4-6 (Cambridge, Cambridge University Press, 1978).

67 See A Businessman's View of Lawyers, 33 Business LAwYer 817, 845 (1978): "For a businessman, court litigation is not nearly as important as his dealings with a whole variety of governmental agencies. The IRS and the SEC come readily to mind, and there are also the ICC, EPA, DOT and a host of others. I would estimate that most of our arguments and controversies are with these institutions."

68 See C.-A. Colliard, Libertés publiques ix-xi (Paris, Dalloz, 5th ed., 1975).

69 See The Remedial Process in Institutional Reform Litigation, 78 Columbia Law REVIEW 784, 929 (1978).

70 See, e.g., Discrimination in Employment (Stockholm, Almqvist \& Wiksell, F. Schmidt ed., 1978). Even the judicial courts do not always do their utmost to reduce discrimination. See Note, Implied Rights of Action to Enforce Civil Rights: The Case for a Sympathetic View, 87 Yale Law Journal 1378 (1978). 
philosophy common at his time. Today, we expect the government to control the economy (and not only the economy in general, but every economic act, minute as it may be ${ }^{71}$ ) and to take care of the citizen in every respect. No wonder the state has become an enormous machine. ${ }^{72}$ It is more than ever "that great Leviathan" denounced by Hobbes.

The problem of access to justice has been transformed as well. During the 19th Century, most citizens lived their lives without even thinking of seeking formal justice. Law was relatively simple and respected by everyone. It could be forgotten in daily life. Our legal relations today are less with our fellow citizens than with the governmental administration. Even when we deal with our fellow citizens, our relations are largely under the control of that administration. We cannot drive an automobile without a driver's license, and the vehicle must meet very detailed standards. We cannot build a house on our piece of land without a building permit. ${ }^{73} \mathrm{We}$ cannot lease or sell an apartment without coming under the sway of very complex legislation. We have more or less constantly to deal with the social security administration.

The problem of access to justice in the welfare state thus largely becomes the problem of access to a very complex social and administrative machinery and - but this is only a second stage - the problem of control of the fairness of the decisions made by this machinery. These are enormous problems. First of all, many citizens are not even aware of their rights, and, often, these citizens are precisely the ones who most need assistance. ${ }^{74}$ They may also have

71 See, e.g., the task of the British Office of Fair Trading as defined by its Director General: Borrie, The Work of the British Office of Fair Trading, in Access TO JUSTICE: EMERGING Issues AND PERSPeCtives, supra note 2, at 495, 497.

72 The expenditures of the federal government of the United States have grown from $\$ 5$ billion in 1939 to $\$ 100$ billion in $1966, \$ 210$ billion in $1971, \$ 324$ billion in 1975 and $\$ 452$ billion in 1978 . From this amount, $\$ 163$ billion (i.e., more than one third) were spent by the Department of Health, Education and Welfare (against \$104 billion for the Defense Department), and this even though the social expenditures of the nation are far from being all under the control of HEW. The state budgets must have increased in similar proportions. Their total expenditures for the 1977 fiscal year amounted to \$191 billion.

For a sketch of the French social (purely social) machinery, see J. FourNIER \& N. QUESTIAUX, supra note 57, at 175 et seq., 480 et seq., 497 et seq. For a larger view of the French administration, see J. Auby \& R. Ducos-Ader, Institutions administratives (Paris, Dalloz, 4th ed., 1978); but the picture is far from complete.

73 On the current problems of zoning in the United States, see the May 1978 issue of Harvard Law Review, i.e., Vol. 91 at 1373-1708.

${ }^{74}$ A recent study shows that families having the greatest need for social assistance are those which call on it least. LA VIE PRÉCAIRE DES FAMILLES FACE À LEURS DIFFICULTÉs 171 et seq. (Paris, Caisse nationale des allocations familiales, A. Pitrou ed., 1979). 
difficulty in finding the proper administrative branch or office to which they should apply. They may frequently be confronted with a failure to reply on the part of the administration. In any event, a fair discussion is rarely assured between civil servants, who have special knowledge of the matter and the power of decision, and applicants, who do not know exactly for what they should ask and are often unable to express themselves with clarity (many nowadays being immigrant workers). Finally, if someone has the feeling that he has not obtained what he was entitled to, he should have some means of recourse - but since the interest he claims is often a small one, ${ }^{75}$ the means of recourse need to be organized so as not to prevent such small claims from being heard.

\section{Some Specific Problems and Trails toward Access to Justice in the Welfare State}

Up to this point, this report has only given an idea of the difficulties of access to the administrative and social machinery of justice in the welfare state. The task of a reporter, however, should be a positive one. In the present case he could be expected to give a picture of what has already been done to facilitate access to the legal system and what could still be done. ${ }^{76}$ Unfortunately, that task is impossible to fulfill. Professor Street mentions that he has spent years in examining some of the British systems of control. ${ }^{77} \mathrm{I}$ cannot hope to submit to you the solutions of the numerous and intricate problems we have found. I cannot even distinguish and treat separately access to the legal system in the three fields of liberties, economic regulation and welfare legislation. It is true that from one of these fields to the next, the difficulties of ensuring access to the legal system increase. But many problems are common to the three fields. And no problem is so specific to one field that it is irrelevant in the others. I am therefore bound to continue writing in generalities, very close to platitudes.

75 As correctly underlined by Cappelletti \& Garth, supra note 2, at 20-21.

76 See VERS UNE PROTECTION EFFICACE DES DROITS ÉCONOMIQUES ET SOCIAUX? (Brussels/Louvain, Bruylant/Vander, 1973).

$77 \mathrm{H}$. STREeT, supra note 65 , at 69. 


\section{Efforts to Clarify and Publicize Legal Rules}

First, every effort should be made to clarify legislation and make it more accessible to the ordinary man. No one can expect the volume of legislation to be reduced: This volume is a response to the growing difficulty of assuring justice in society and the growing expectancy of justice. However, English landlord and tenant legislation has been officially described as "a source of frustration and anxiety to landlords, tenants and those responsible for administering and interpreting the legislation"; a leading author has written that the main drafting vices of this legislation "can be put under the five heads of inadequate definition, hidden meanings, missing principles, incautious superimpositions, and plain mistakes." 78 Are such problems inevitable?

This is, I suggest, a very important question. We earlier said that the problem of access to the legal system cannot be divorced from the problem of the value of the legal system. The problem of the accessibility of the legal system with respect to its form and its intrinsic presentation, apart from the mechanisms of access, is even closer to our present concern. It was for greater accessibility to the legal system that the French people clamored for centuries for a codification of the various legal customs and obtained in 1804 the Civil Code. ${ }^{79} \mathrm{I}$ personally believe that codification brought the legal rules closer to the ordinary people and that, in the traditional fields of law, codification has retained its value. ${ }^{80}$ But there is no point discussing here the merits of codification as understood by the drafters of the Civil Code, since the legal rules typical of the welfare state are bound to be expressed in a style which has little relation to that of

78 R. Megarry quoted in O' Donoghue, Book Review, 42 Modern Law Review 235 (1979). Another reviewer writes: "The Children Act has nightmare characteristics, not only is it being implemented gradually, but also it legislates by reference to other Acts so that many of its sections are incomprehensible unless the reader has recourse to, and is familiar with, the relevant statutes and case law. Furthermore...." Hayes, Book Review, 42 Modern Law REVIEw 229 (1979). Once more, is it inevitable?

In France, a statute of January 3, 1977, creating a new regime for the "aid to housing" has been followed within two years by 70 decrees (décrets et arrêtés). How can the ordinary man know his rights? On March 13, 1979, eight new arrêtés were issued.

79 See Tunc, The Grand Outlines of the Code, in The Code Napoleon and the ComMON-LAW WORLD 63 (New York, New York University Press, 1956).

80 See Tunc, Methodology of the Civil Law in France, 50 Tulane Law Review 459 (1976); Tunc, Codification: The French Experience, in Problems of Codification 63 (Canberra, Australian National University Press, G. Stoljar ed., 1977). 
the Civil Code. They usually do not state broad principles, but are rather, by necessity, extremely detailed in their contents. This is certainly a serious problem for access to the legal system.

Some governments have at least produced booklets giving the ordinary citizen a reasonably clear and accurate view of the law in certain fields, as well as practical indications as to what to do in order to obtain satisfaction. Even though such booklets are in danger of becoming rapidly obsolete, this is a practice which should be encouraged. A number of private companies have also published several "practical law" handbooks. Such initiatives are certainly very useful, but they tend to address persons of some means. ${ }^{81}$ There is a public responsibility not only to take measures in favor of the underpriviliged, but also to make these measures known to them through pamphlets.

A more personalized means of bringing the benefits of social legislation to the people who most need them is to make social workers and neighborhood advice centers accessible to everyone. ${ }^{82}$ Their task is very important. To a certain extent - even though the contrast should not be exaggerated - they solve the problem by reversing it: they attempt to give to legal rules and legal institutions access to the people who need them; they deliver the legal system. Unfortunately, the organization of social workers, at least in France, is very defective. ${ }^{83}$ Some social workers are employed by private firms, others by various public bodies. Their task is often ill-defined and sometimes considered by their employers as more or less a marginal one. For this reason, their recruitment and training often leave much to be desired. As middlemen between the lower and upper classes of the nation, or between the former and the administration, they are caught up in the tensions and are sometimes considered suspect by both sides. If they work earnestly, they have more or less constantly to report complaints, and thus often appear as permanent

81 In France, a GUIDE DE LA PROTECTION SOCIALE (F. Lejeune ed.) has been published by a private firm. This is certainly a most useful tool. But it is a two-volume, loose-leaf service and costs 450 French francs. This means that it is unavailable to those who need social protection.

82 See A. Byles \& P. Morris, Unmet Need: The Case of the Neighbourhood Law Centre (London, Kegan Paul, 1977); J. Baker, The Neighbourhood Advice Centre: A Community Project in Camden (London, Kegan Paul, 1978); B. Garth, supra note 6. On the inadequacy of traditional legal services, see Cappelletti \& Garth, supra note 59, at xiv-xv.

83 As regards England, see Phillips, Social Work and the Delivery of Legal Services, 42 MODERN LAW Review 29 (1979). 
trouble-makers. Finally, they themselves may have difficulties finding their way in the administrative maze. For these various reasons, they often become discouraged and do not provide full social assistance to the people who need it. ${ }^{84}$ The creation of neighborhood advice centers, however, probably remains one of the most promising solutions. ${ }^{85}$

\section{Administration "with a Human Face"}

Access to justice presently also implies an administration "with a human face." This, by itself, is obviously an enormous problem. ${ }^{86}$ Periodic efforts are made by governments to help citizens find their way in the administration, to simplify the forms they must fill in, to help them know and understand the decisions taken, and to promote courteousness among the civil servants. Administration with a human face also requires an administration which, to the greatest possible extent (but here we are especially bound to remain in the realm of generalities), works in cooperation with the citizens and includes their representatives in its organs, ${ }^{87}$ provides a hearing to the party concerned and the other persons interested in that particular matter, opens its files, explains its decisions in a proper opinion, ${ }^{88}$ and submits itself to all the requisites of "natural justice," "fairness" or "principes généraux de droit." 89 Additionally, an administration with

84 See Lestienne et al., Le malaise des travailleurs sociaux, 1979 PROJET 442 et seq.

85 In France, creation of such centers has been advocated in the recent report of a special commission. See Peyrefitte, in Comité d'Études sur la viOlence, LA CRIMINAlité et LA Délinquance, Résponses À la violence 208 (Paris, Presses Pocket, 1977); Levasseur, Pettiti \& Stanciu, Au sujet des "Réponses à la violence," [1978] Recueil Dalloz Sirey, Chronique 205, at No. 14. See also LA VIE PRÉCAIRE, supra note 74, at 237.

86 See Friedman, supra note 33 , at 36.

87 See C.-A. Colliard, supra note 68 , at xii-xiii; Cappelletti \& Garth, supra note 59, at $\mathrm{xv}$; Trubek, supra note 44.

88 See decision of the Conseil d'Etat of July 7, 1978 (CEVAPIC), [1979] RecueIL DaLLOZ SIREY, Jurisprudence 187 , with note by Couzinet.

89 See Lefas, Essai de comparaison entre le concept de "natural justice" en droit administratif anglo-saxon et les "principes généraux du droit" ainsi que les "règles générales de procédure" correspondants en droit administratif français, 1978 REVUE INTERNATIONALE DE DROIT COMPARÉ 745 et seq.

A serious effort has been made to improve the relations between the administration and the citizens in France. See Loi No. $78-753$ of July 17, 1978, portant diverses mesures d'amélioration des relations entre l'administration et le public et diverses dispositions d'ordre administratif, social et fiscal. At the moment I am writing this report (April 27, 1979) the Parliament is considering a Bill on the obligation for the administration to give an opinion for its decisions, and the President of the Republic has just written to the Prime Minister, urging him to make administrative procedures easier and the relations between the administration and the public more human ones. Le Monde, April 27, 1979. On the other hand, the Médiateur, in an official 
a human face has to work efficiently and speedily. Unfortunately, the administrative process all too often generates a feeling of "crisis." 90

\section{Control of Administrative Action}

If assuring access to the social and administrative machinery of the welfare state thus appears as an enormous problem, a second problem, of equal importance, is to assure some means of controlling this machinery, be it by courts, ${ }^{91}$ an ombudsman, parliamentary commissioner, médiateur or prokuratura, and, if necessary, of redressing the wrongs it may have committed. We obviously cannot hope usefully to explore here the respective merits of ombudsmen, parliamentary commissioners, médiateurs and prokuratura. ${ }^{92}$ Nor can we hope to explore the respective merits of control of administrative action by ordinary courts or by special administrative courts, as in France. ${ }^{93}$ We can, however, underline the need for speedy decisions, as speed is essential to justice in the social and administrative fields even more than in the traditional fields. To take only one example, if a foreigner is expelled from France, it does not do him any good to learn some years later that he was entitled to stay. ${ }^{94}$ If

report to the President of the Republic, has just described the situation of the citizen in his relation to the administration as "martyrdom." Le Monde, May 9, 1979.

90 See J. FreEdMan, supra note 66. See two recent articles (among many others) dealing with basic questions: Rosenblatt, Health Care Reform and Administrative Law: A Structural Approach, 88 Yale Law Journal 243 (1978); Note, Judicial Control of Systemic Inadequacies in Federal Administrative Enforcement, 88 YALE LAw Journal 407 (1978).

91 The 1977 U.S.S.R. Constitution, in art. 58, para. 2, submits administrative actions to the control of the courts as to their legality. This is a novel development in the U.S.S.R. Its importance cannot yet be appreciated. It seems to have raised great expectations. See M. LeSAge, La Constitution DE L'U.R.S.S. DU 7 OCtOBRe 1977, TeXte et commentaire 58 (Paris, La documentation française, 1978); P. Lavigne \& M. Lavigne, Regards sur LA CONSTITUtion SOviÉTIQUe DE 1977128 (Paris, Economica, 1979).

92 See, however, G. Braibant, N. Questiaux, \& C. Wiener, Le contrôle de l'adMINISTRATION ET LA PROTECTION DES CITOYENS (ÉTUde COMPARATIVE) (Paris, Cujas, 1973).

See also on the "continuing proliferation of the ombudsman institution," Cappelletti \& Garth, supra note 2, at 104-05. For a comparison of the British parliamentary commissioner and the French médiateur, see Huitième colloque juridique franco-britannique, 1977 REvUE INTERNATIONALE DE DROIT COMPARE 388 et seq.; on the Yugoslavian "social lawyer of self-determination," see Denković, L'avocat social de l'autogestion, 1978 Revue inTernationale DE DROIT COMPARÉ 969 et seq.

93 Civilians will find a useful picture of the control of economic administration in the United Kingdom in Y. Fortin, Le contrôle de L'administration Économique eN Grande Bretagne (Paris, Editions du Centre national de la recherche scientifique, 1978).

94 See the decision of the Conseil d'Etat of December 22, 1978 (Cohn-Bendit), [1979] RECueil Dalloz Sirey, Jurisprudence 155 , with conclusions by Genevois and a note by Pacteau, [1979] Juris-Classeur PÉRIOdique II. 19158, with note by Kovar.

On December 5, 1975, Daniel Cohn-Bendit petitioned for the repeal of an expulsion decree. The petition was denied on February 2, 1976. Cohn-Bendit then submitted the case to 
special administrative courts exist, the boundaries of their jurisdiction should also be clear, since social services are often at the borderline of "private law" and "administrative law," thus creating conflicts of jurisdiction which presently take years to settle. 95

With respect to judicial control of administrative action, we should mainly raise two far-reaching questions, even if we feel unable to answer them. The first one is whether such control is a requisite of justice, as seems more or less obvious to us. The matter has recently been discussed in the United States, a country where administrative action is in principle subject to the control of ordinary courts. The courts may thus have to pass on trivial problems which may turn essentially on questions of fact and require for their solution the skill of any man with common sense rather than a qualified lawyer. ${ }^{96}$ This matter deserves reflection. Do we not make a fetish of judicial control? What are its respective merits and social costs? When we pride ourselves on such and such a judicial decision which has vindicated liberty or justice, are we aware of the burdens and impediments we permanently impose upon an administration

the administrative court of first instance. The latter, on December 21, 1977 submitted two preliminary questions to the Court of Justice of the European Communities. On December 22, 1978, the Conseil d'Etat quashed the decision and required the court of first instance to make a decision.

95 See, e.g., the decision of the First Civil Chamber of the Cour de Cassation of April 19, 1977, [1979] Recueil Dalloz Sirey, Jurisprudence 197, with note by Plouvin. The Cour de Cassation in 1977 quashed the decision of a court of appeals applying private law to a decision made by a city in 1973 regarding a social service. The case was remitted to another court of appeals which would probably declare that it has no jurisdiction. Practically, the parties will probably save the trouble of going to the second court of appeals. However, four years will have been lost before the conflict is submitted to the administrative court.

96 In his address delivered to the entering students of the University of Chicago Law School, see note 54 supra, Judge McGowan submitted the following facts and reflections:

Not long ago there was a case in our court involving recently enacted coal mining legislation where the ultimate question was whether, in the language of regulations issued by the Secretary of the Interior pursuant to statutory authority, the bathhouse was conveniently located to the mine head. Now I am sure that if I were either a coal miner or a mine owner adversely affected by a field inspector's ruling on his score, this would be an issue of consequence that I would like to be able to take to some impartial and expert authority for a further look.

What Congress had in fact provided in this regard was a full evidentiary hearing and adjudication by an administrative law judge in the Interior Department; full appellate review within the Department including consideration by the Secretary or a Board designated by him; a review of that determination by a circuit court of appeals; and, finally, the opportunity to seek further review in the United States Supreme Court. This strikes me as resort to legal processes run riot. I cannot believe that the Republic would fall or the foundations of our liberties be demolished if an issue of that kind is resolved once and for all at a much earlier stage, and arguably without the aid of the courts at all. 
working for the common good? ${ }^{97}$ I suggest that, at least, administrative courts such as the ones we have in France are better equipped than judicial courts to strike the proper balance between the needs of the administration and the rights and freedoms of the individual citizen.

The second question concerns a somewhat different problem. In France, at least, judicial control of the welfare administration has been organized step-by-step and according to the particular service. As new legislation was passed, or as a new service was introduced, a new institution for its implementation or eventual control was established. There is much to be said in favor of this approach. ${ }^{98} \mathrm{Did}$ we not, however, carry it too far? Would not a streamlining be necessary? Should not the specialized courts now existing for controlling the administration of individual areas of social-welfare law be replaced by a court structure controlling the administration of the entire social-welfare law? Such is the question I would like to consider briefly here.

The present situation is extremely complex in France ${ }^{99}$ - and the situation may be comparable in a number of other countries. Conflicts between the social security administration and a person involved in the social security program are, after a purely administrative procedure, normally submitted to special local commissions composed of a professional judge and two associates selected by him on the nomination of the most representative unions from a list drawn up by the regional director of the social security administration. Appeal (on the facts as well as on points of law) lies with the normal court of appeal, the cour d'appel, and from there (on points of law only) with the supreme non-administrative court, the Cour de Cassation. Conflicts concerning temporary disablements follow the path of normal social security litigation. Many cases of permanent disablement, however, provided they fall within statutory definitions,

97 See Friedman, supra note 33, at 36

98 Cappelletti \& Garth, supra note 2, at 52-53.

99 See J. Dupeyroux, Droit de la sécurité sociale, at Nos. 375 et seq. (Paris, Dalloz, 7th ed., 1977). For other countries, see Association INTERNATIONALE DE LA SÉcurité SOCIALE, Le CONTENTIEUX DANS LA SÉcurité SOCIALE (Geneva, Secrétariat général de l'A.I.S.S., 1965); AsSOCIATION INTERNATIONALE de la SÉCURITÉ SOCIALE, Le CONTENTIEUX DANS LeS CAISSES DE SÉCURITÉ SOCIALE en AFRIQUe (Geneva, Secrétariat général de l'A.I.S.S.,

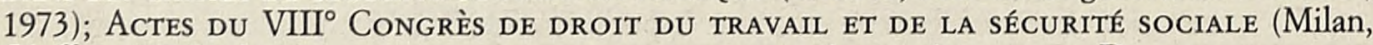
Giuffrè, 1974); Association inTERnAtionale de la sécurité sociale, Documents AFriCAINS DE SÉcurité sociale (Geneva, Secrétariat général de l'A.I.S.S., 1976). 
are submitted to other commissions. Such cases may be appealed (on the facts as well as on points of law) to a national commission and from it (on points of law only) to the Cour de Cassation. Conflicts with respect to the levies for financing the workers' compensation scheme are submitted to another section of the national commission and then, on appeal, to the Cour de Cassation. Cases of misconduct or dishonesty by members of the medical or para-medical professions when dealing with persons covered by the social security program are submitted to a special tribunal, with appeal to another one, and from it to the Conseil d'Etat. A number of other confiicts, however, are brought to the normal administrative courts of first instance, the tribunaux administratifs, with a possibility of appeal to the Conseil d'Etat. But some problems are under the exclusive jurisdiction of the non-administrative courts, the tribunaux d'instance and tribunaux de grande instance, while, of course, only criminal courts can impose criminal sanctions. Finally, various tribunals have been set up either by collective agreements or by special legislation concerning, for instance, military personnel or seamen.

This is already a remarkably complex picture. However, it concerns only the resolution of conflicts arising from the administration of the social security program in a rather narrow sense. In France, it is a tradition that health services, social aid (aide sociale) and social action (action sociale) are treated as distinct from social security.

Hospital care constitutes a public service, but does not have any monopoly. Therefore, the relationships between the private and public sectors engaged in health activities are very complex. ${ }^{100}$ If justice is sought, it must be obtained from the judicial or administrative courts, according to rules which often remain uncertain.

Social aid is the aid given to persons with insufficient financial means. ${ }^{101}$ It is not, as social security, based on an idea of mutuality and does not require a contribution on the part of the beneficiary. It takes various forms, including medical aid. ${ }^{102}$ If a person needs this type of assistance, he must apply to a commission d'admission, composed of a professional judge, two civil servants from the Treasury,

100 See J. Dupeyroux, supra note 99, at Nos. 68 et seq., 407 et seq.; E. Alfandari, supra note 64 , at 78 et seq.

101 See J. Dupeyroux, supra note 99, at Nos. 407 et seq.; E. Alfandari, supra note 64, at 1 et seq., 25 et. seq. (on the relationship between social security and social aid, see $i d$. at 78 et seq.).

102 E. Alfandari, supra note 64, at Nos. 226 et seq. 
one representative of a regional elected body and the mayor or his representative. ${ }^{103}$ If the request is rejected, the person may submit the matter to a special court. ${ }^{104}$ Appeal lies with a central commission, the complexity of which defies any effort at description. ${ }^{105}$ The decision of the latter may still, in particular cases, be submitted to the Con seil d'Etat. Some matters having to do with social aid, however, are under the jurisdiction of the normal judicial courts or of the social security courts. Thus, the person who seeks access to justice in the field of social aid may have great difficulty in finding his way. Furthermore, one of the leading experts in this area is of the opinion that special social aid courts are often unfair, since the influence of the civil servants from the Treasury is excessive. ${ }^{106}$

Social action is another related governmental activity, more modern and more flexible. It covers a number of public initiatives which have as their purpose filling the gaps left by social security, helping achieve the protection or promotion of a particular class of people (youth, the handicapped, the elderly), and improving the overall social or socio-cultural environment (communal facilities, arts, activities, suppression of nuisances, etc.). ${ }^{107}$ Its promoters are the Health Department and various other departments, as well as the social security administration. ${ }^{108}$ The question whether some people may claim a right to benefit from this action is not clear. ${ }^{109}$ The small amount of litigation to which it gives rise normally goes before the ordinary administrative courts, even though some of it may be resolved in social security tribunals.

Is such a fragmentation necessary, or even useful? The tribunals and courts dealing with social security legislation are either specialized but of low calibre, or of high calibre but without specialization. They have been created to give prompt and ad boc answers to specific needs. But one suspects that it would be advantageous to create a special system of courts dealing with the entire body of social legislation. This was the proposal made a few years ago by an eminent member of the Conseil d'Etat, President Pierre

${ }^{103}$ Id. at Nos. 134 et seq.

$104 \mathrm{Id}$. at Nos. 153 et seq.

105 Id. at Nos. 157 et seq.

106 Id. at No. 164.

107 Id. at No. 69.

108 On the sanitary and social action of the social security administration, see also J. Dupeyroux, supra note 99 , at Nos. 268-78.

109 E. Alfandari, supra note 64, at No. 68. 
Laroque. ${ }^{110} \mathrm{He}$ argues that all social legislation is inspired by the same philosophy and based on the same principles, and that its administration is entrusted to public bodies different from the traditional ones, if only because they often include, sometimes on an equal footing, representatives of the people concerned. He convincingly shows that, while we in France traditionally make a distinction between private and public law, we should now similarly distinguish social law from both of them and, as a result, greatly improve the administration of justice by creating an autonomous system of courts for administering such social law. In the opinion of President Laroque, these social courts should have jurisdiction not only over disputes involving social-welfare legislation, but also over labor disputes of an individual nature (dealt with in the first part of this report) as well as over labor disputes of a collective nature. ${ }^{111}$

The social courts should be composed of career judges, who would be independent of the judges of the civil and administrative courts, but would receive an equally sound legal training and, in addition, be instilled with a specific knowledge of social matters by means of special courses as well as periods in public service and private enterprise. The organization of the social courts would be similar to that of the civil courts, with local and regional courts and a supreme court on the same level as the Cour de Cassation and the Conseil d'Etat. There would, however, be greater flexibility in the jurisdictional division of the three levels of courts. Some problems, by reason of their nature or importance, could be brought directly before the regional or even the supreme court. The social courts should also provide very swift justice; to that end, their procedure could be inspired by that of the conseils de prud'bommes: 112 they should abandon the majesty of the adversary process as it is presently practiced and offer a justice which is "cheap," not in terms of quality, but of expense.

President Laroque's suggestions were not followed. They may have seemed too ambitious. Their implementation would have raised many practical psychological and political problems. They have not, however, been forgotten. One cannot fail to be impressed by the

110 Laroque, Contentieux social et juridiction sociale, 1954 DroIT SOCIAL 271 et seq.

111 Our General Reporters remarked that "disputes have collective as well as individual repercussions" (Cappelletti \& Garth, supra note 2, at 53). This is particularly true as far as labor disputes are concerned.

112 See note 32 supra. 
strength of the demonstration on which they are based. They deserve to receive the most serious consideration as a means of facilitating access to a better justice.

Even though, once again, definite conclusions cannot be expected in this part of the report, I may confess that I would be inclined to think that the administration of justice would be improved and access to it facilitated if, as suggested by President Laroque, three systems of courts were set up, judicial, administrative and social, provided, however, that a mechanism for a prompt settlement of conflicts of jurisdiction between the three systems is also instituted. ${ }^{113}$ This would not, of course, excuse us from looking for ways of improving regular court procedures. ${ }^{114}$ On the contrary, the experience gained in one system could suggest improvements in the procedures of the others. Nor would such a reform eliminate the need for some special courts in certain fields of law - environmental protection, for instance. ${ }^{115}$ But it would at least improve justice and access to justice in the whole area of social law. This conclusion may seem, on its surface, to be contradicted by the prophetic Hamlyn Lectures of Sir Leslie Scarman, ${ }^{116}$ who is anxious to preserve the universality of the law and seems in favor of placing it entirely in the hands of the ordinary courts. ${ }^{117}$ The contradiction, however, is probably more superficial than real. We share the same concern for the universality of the rule of law and for an increased attention to the new legal problems of the community. I entirely subscribe to the propositions that "the welfare state is challenging the relevance, or at least the adequacy, of the common law's concepts and classifications" and that "our legal structures lack a sure foundation upon which to build a legal control of the beneficent state activities that have developed in this country." 118 It is precisely on the basis of these ideas that I would suggest that recognition be given to a certain specificity of the three great branches of the law and to the desirability of a certain diversity in the methods of administering them.

113 See note 53 supra.

114 See Access to Justice: Promising Institutions, supra note 2, at $429-87$ (Part Three: Improving Regular Court Procedures).

115 See Cappelletti \& Garth, supra note 2, at 100-01, on the Japanese experiments.

116 L. Scarman, English Law: The New Dimension (London, Stevens \& Sons, 1974). Compare Lord Justice James, supra note 54.

117 See id., particularly at 72, 73, 75. See Lord Denning, supra note 5, at Part II.

118 L. SCARMAN, supra note 116 , at $70,71$. 


\section{Computers and the Danger of a Police State}

Finally, mention should be made in this report of the danger of the welfare state turning into a police state, especially in connection with the use of computers. This is a well-known and multifarious danger even under our present form of government and with a wellintended administration. For example, social authorities conducting scientific research on the factors leading to delinquency found it useful to file the names, at their birth, of children in danger of becoming delinquents and to register their misbehaviors. This was done in order to provide them with guidance and to give them warnings. But it could be used by the police in search of a delinquent and even at a trial as a presumption of guilt. In the United States, newspapers reported that President Carter, on April 3, 1979, asked Congress for legislation protecting Americans from computer-age threats to privacy. Such legislation would include a Privacy of Medical Informations Act, a Privacy of Research Records Act, and a Fair Financial Information Practices Act. In France, after the problem was thoroughly investigated by a special commission, ${ }^{119}$ Parliament passed Loi No. 78-17 of January 6, 1978, relative à l'informatique, aux fichiers et aux libertés. 120 This statute, among other measures, creates a Commission nationale de l'informatique et des libertés, the first Chairman of which was none other than Mr. Pierre Bellet, Premier Président de la Cour de Cassation.

\section{Access to "Justice”}

Attention has already been drawn to the modest title given by the organizers of the Colloquium to this session, which refers only to "Access to the Legal System." The legal system, however, is not an aim in itself. It is only a means to realize justice. This justifies a last enquiry on how far we are from access to "Justice."

119 B. Tricot, InformatiQue et libertés (Paris, La documentation française, General Report, 1975).

120 See also Decree No. 78-774 of July 17, 1978. 


\section{A. "Iustice"}

I shall not try to define justice. Aristotle himself failed to do so and apparently knew that his attempt would end in failure. ${ }^{121} \mathrm{I}$ shall only recall that, recently, a new effort has been made in this direction. John Rawls, in a very systematic study, was led to the conclusion that: "All social values - liberty and opportunity, income and wealth, and the bases of self-respect - are to be equally distributed unless an unequal distribution of any, or all of these values is to everyone's advantage." 122

Rawls' book has revived such an interest in the matter that other studies have been written, commenting upon it. ${ }^{123}$ Ronald Dworkin prefers to say that "individuals have a right to equal concern and respect." ${ }^{124}$ Some authors feel that no single theory can account for the complexity and diversity of the concept of justice ${ }^{125}$ and that one should even admit that justice cannot be the only goal of society. Still, there is certainly general agreement that equality is an important ingredient of justice and that justice is a most important value. By this standard, it is clear that the world and all given human societies are still very far from justice - and equally far from the goals of the welfare state.

Let us consider, first, the world as a whole. Equality? Freedom from want? While some nations have a very high per capita national income, three quarters of the human race live under inhuman conditions, deprived of what is necessary for a decent life. European or North American cattle enjoy greater protection from hunger and disease than billions of human beings in Asia, Africa and Latin America. One may estimate at roughly 100,000 the number of youngsters who die every day because they were born in under-developed countries.

121 Winthrop, Aristotle and Theories of Justice, 72 American Political Science ReVIEW 1201 (1978).

122 J. Rawls, A Theory of Justice 62 (Cambridge, Belknap Press of Harvard University Press, 1971).

123 Among them: B. Barry, The Liberal Theory of Justice (Oxford, Clarendon Press, 1973); R. Wolf, Understanding Rawls (Princeton, Princeton University Press, 1977). 1977).

${ }_{124}$ R. Dworkin, Taking Rights Seriously, particularly at Ch. 6 (London, Duckworth,

125 D. Miller, Social Justice (Oxford, Clarendon Press, 1976). 
Freedom from fear? "The right of every man to international peace" - which a French parliamentary commission would like to insert in the Constitution? ${ }^{126}$ From 1945 to 1977 - barely more than 20 years - 80 major conflicts have been registered, which killed more than 12 million people, ${ }^{127}$ and the situation has probably deteriorated further in the most recent years. Mankind presently devotes more than 350 billion U.S. dollars every year to armaments, i.e., nearly one billion per day. ${ }^{128}$

Such discrepancies between the current situation and the collective expectations of billions of people are the seeds of a deep and threatening world-wide unrest. ${ }^{129}$ International justice is obviously much more difficult to attain than national justice, particularly since it has followed the same evolution as national justice and is now conceived of as based on needs as well as on rights in the traditional sense. However, even if we consider only national societies, we find that justice is still very far from achieved.

In all nations, minorities - be they ethnic, religious, or even political - are generally underprivileged and may find it more difficult than the majority to gain access to legal and social justice and to the political recognition of their needs and rights. ${ }^{130}$ In most nations, women, even though they form a slight majority, are subject to subtle discriminations and experience greater difficulty in obtaining the opportunities and responsibilities they deserve. ${ }^{131}$

Quite apart from any specific category, social inequalities are still

$126 \mathrm{~J}$. Mourgeon, supra note 58 , at 89.

127 Id. at 19.

128 The Arms Race, UNESCO Courier, April 1979.

129 J. Mourgeon, supra note 58, at 63-65.

130 See Les travailleurs émigrés, 1976 Drort social (special issue, J. Dupeyroux ed., May 1976). To take another example, in the United States,

killing a white is more likely to bring the death penalty than killing a black. In Alabama, for instance, on the basis of 1,395 murders and 41 death sentences, it is twelve times more likely. Even though roughly equal numbers of blacks and whites were killed in Georgia, Texas and Florida from 1973 to 1977, 90\% of the convicts on death row got there by killing whites, according to a study by sociologists William Bowers and Glenn Pierce of Northeastern University.

Time, April 16, 1979. To take a further example on the way the "right to education" is being implemented, see Isambert-Jamati, Sociologie de l'éducation, 1976 L'ANNÉE SOCIOLOGIQUe 529 et seq.

${ }^{131}$ E.g., out of 1,113 judges covered in a comparative research on the supreme courts, 41 only are women. Tunc, in P. Bellet \& A. Tunc, La COUR JUdiciaire suprême, Une ENQUÊTE COMPARATIVe 33 (Paris, Librairies techniques, 1978). Similarly, only 276 women sit in the boards of the nation's biggest 1,300 corporations. TIME, March 19, 1979. See also La femme et de droit social, 1976 Droit social (special issue, J. Dupeyroux ed., January 1976). 
very serious and very difficult to correct in most countries. ${ }^{132} \mathrm{~A}$ child born in a slum will have every chance of becoming a delinquent of some sort and many chances of going to jail. Once he has been put in jail, even for a short period, we all know how difficult and problematic his rehabilitation will be. He would have escaped this fate if he had only been born in another district of the same city.

Studies carried out by Amnesty International show that torture, in one form or the other, has recently been used, or is still being used in most nations, including the "most civilized ones."

An advertisement for the Antitrust Law and Economic Review published in various law journals of the United States asserts that "monopoly, by the most conservative of estimates, raises consumer prices by some $9.2 \%$ of the G.N.P., roughly $\$ 180$ billion per year, or about $\$ 2500$ per family per year in monopoly overcharges" and a book was recently published on Les grands escrocs en affaires. ${ }^{133}$

That we are dramatically far from justice even in the national communities, and dramatically far from all the well-intended declarations of rights, is too obvious to require further elaboration.

\section{B. Limitations and Risks of the Access-to-Justice Approach}

What remains to be done, following the example of the Project's General Reporters, ${ }^{134}$ is to point out some limitations and risks of the access-to-justice approach.

The first risk underlined by the General Reporters is that "streamlined, efficient procedures will abandon the fundamental guarantees of civil procedure" and that "the pressure on the legal system to reduce its burden and find still cheaper procedures" will imperil "the core values of traditional procedural justice." $135 \mathrm{We}$ are seeking a justice cheap in terms of cost, not of quality, and these

132 E.g., Les inégalités Sociales, Situation mÉCANismes, aCtions CORReCTRICES (Paris, Centre national de la recherche scientifique, J. Belorgey \& J. Dupeyroux eds., 1977); L'exclusion sociale, 1944 Drort social (special issue, November 1944). See also the various publications of the movement Aide à Toute Détresse, Quart-Monde, Editions science et service (France, 95480 Pierrelaye), in particular: Le sous-prolétariat de France, LIVRe BLANC (1977); A. De Vos van SteENwIJK, Le QUaRT-MONDE PIERRE DE TOUCH DE LA DÉmocratie européenne (1977); F. DE La Gorce, LA GAFFE DE DIEU (1979).

133 J. Cosson, Les grands escrocs en affaires (Paris, Le Seuil, 1979).

134 Cappelletti \& Garth, supra note 2, at 120-24.

$135 \mathrm{Id}$. at 123; see also id. at 21. 
goals may not be compatible. At the extreme, we might be seduced by the mediatory role currently played by the Japanese police and generally considered as beneficial. ${ }^{136}$ But the practice exposes the parties to pressures exerted by the police officers, and we are reminded that some compromises may amount to capitulation. ${ }^{137}$ This problem, unquestionable as it is, may not be the most serious. A balance may be found between the opposing needs. In all likelihood, the majesty of the traditional procedure can be challenged without sacrificing the quality of the administration of justice. To the contrary, ${ }^{138}$ the research conducted within the Access-to-Justice Project has shown the variety of measures which could be combined in order to improve the settlement of disputes by the courts. ${ }^{139}$

To go further, I would personally confess to having ruminated a number of times on an experience of mine made in Cambridge, England. I spent a full day in the Crown Court, attending the trial by jury of a petrol-station employee accused of having stolen coupons in the value of 80 pence. The trial started, I think, at about 9:30 a.m. By 6 p.m., the judge opened the instruction to the jury by stating that the honor of the employee was at stake, exactly as if he were accused of having stolen $£ 80$ million. This is, of course, a wonderful approach to justice. England may pride itself on having produced not only "the best car in the world," but also the best system of administration of justice in the world. Should we, however, maintain such a luxury? Does this type of administration of justice deserve the investments in time, money and talent it requires? For the sake of justice, could we not make better use of our time, money and talent? I would be inclined to think that we could and should make better use of our resources. ${ }^{140}$ Perfection is unattainable. We have a saying in France: "le mieux est l'ennemi du bien."

136 See, uncommitted, Kojima \& Taniguchi, supra note 4, at 733. Apparently, the police in France, and probably elsewhere, play a similar, even though lesser, role. J. CARBONNIER, Sociologique JuRIDIQUe 228 (Paris, Presses universitaires de France, 1978).

137 Johnson, supra note 2 , at 38.

138 Consider, for instance, the Stuttgarter Modell. Bender, The Stuttgart Model, in AccEss to Justice: Promising Institutions, supra note 2, at 431 . On the active role of the court in civil litigation and its dangers, see Jolowicz, in M. CAPPELLETTI \& J. JolowiCz, supra note 12 , at $155-277$.

139 See, in particular, Johnson, supra note 4; Johnson, supra note 2. See Yoshikawa, The Judge's Power to Propose Terms for Settlement: The S.M.O.N. Case, 11 Law IN JaPan 76 (1978).

140 May one point out in this connection: 1) that Rolls Royce was recently near bankruptcy and 2) that the accused in Cambridge was acquitted by the jury, though he was certainly guilty. 


\section{Contradictions in the Reform Effort}

Improving our judicial procedures, however, would still leave us very far from having assured justice in the welfare state. We are caught in contradictions which we cannot escape. We want to facilitate access to justice for small claims and the collection of small debts, but we want to protect the consumer from harsh and abrasive collection practices. We want citizen participation in the regulatory process and the hearing of all concerned citizens when an administrative decision is to be made, and we also want all administrative actions (whether regulatory or individual in nature) to be subject to some sort of control, but, at the same time, we would like the administration to move swiftly and be concerned only with the general interest. We are shocked to find that many rights are not vindicated. But, in France, from 1972 to 1978, the number of lawsuits increased by nearly 75 percent. Can we swallow such a large increase, which theoretically would be justified? Can we divert the litigants toward other means of settlement which would be as satisfactory?

All over the world, we introduce unfair contract terms legislation, which gives the judge power to eliminate or even to re-draft unfair provisions. More broadly speaking, we more and more insert concepts of fairness into our legislation, which in itself is, of course, recommendable. But we forget that fairness is a Trojan horse in a legal system; ${ }^{141}$ it is at least contrary to the concept of certainty of the law, and certainty is essential for easy access to the legal system. We rely on consumer associations to warn the general public concerning the danger of certain products, but the general public may misunderstand their warnings and boycott innocuous products, thus causing without any justification bankruptcies and unemployment. ${ }^{142}$

\section{The Problems of Government Regulation}

A last and basic question may be asked. We have already asked ourselves whether we do not make a fetish of judicial control of the

141 Tunc, Aux frontières du droit et du non-droit: l'équité, in L'Hypothèse DU NONDROIT 281-98 (Liège, Faculté de Droit, d'Economie et de Sciences Sociales de l'Université de Liège, 1978). 1978.

142 See, e.g., Les fabricants de lampes d'ambiance protestent, Le Monde, September 19, 
administration. Do we not also make a fetish of business regulation? Of course, no one wants to return to the 19th Century or even to pre-New Deal capitalism. But is it wise, whenever we see an evil, to introduce legislation or regulation, when the great bulk of such legislation and regulation is in itself an evil? We go to see the physician whenever we have a health problem which is serious or could become serious, but, otherwise, we have to live with some weaknesses and infirmities. In the field of business regulation, we probably have to learn similarly to bear some evils which are to be regretted and theoretically could be eliminated, in order to concentrate public strength on the most important social goals. "La perfection n'est pas de ce monde." Estimates of the annual cost of federal regulation to U.S. industry have ranged from $\$ 79$ billion to $\$ 150$ billion, and these figures seem to be supported by a thorough assessment of the cost, estimated at $\$ 2.6$ billion, caused to 48 firms by six federal regulatory agencies and their programs. ${ }^{143}$ The added costs for these 48 companies were equal to 16 percent of their net profits, 10 percent of their capital expenditures and 40 percent of their research and development budgets. This price may not be too high. The matter, however, deserves to be investigated. ${ }^{144}$

Investigation should be directed not only towards the value of the regulations compared with their costs, but to their intrinsic value and their consistency. ${ }^{145}$ It is a sad fact that most regulations have had unforeseen and unfortunate results. It is also a sad fact that many programs are in conflict with one another, e.g., environmental protection and the energy program. ${ }^{146}$ One cannot fail to be struck merely by the title of Professor Robert H. Bork's 438 page book: The Antirtust Paradox: A Policy at War with Itself. ${ }^{147}$

143 See International Herald Tribune, March 16, 1979; Time, March 26, 1979. The study examined neither the benefits of regulation, nor their secondary costs (delays, for instance). It found the Environmental Protection Agency responsible for $77 \%$ of all the added costs, the Equal Employment Opportunity Commission for $8 \%$, the Occupational Safety and Health Administration for $7 \%$, etc. See also Van Dusen Wishard, Corporate Response to a New Environment, 41 LAw AND Contemporary Problems 222, 234-35 (1977).

144 See Section of Corporation, Banking and Business Law of the A.B.A., Present and Future Problems in Governmental Regulatory Proliferation (A Program by the Committee on the Year 2000), 33 BusINESS LAWYER $433-74$ (1977); Carbonnier, L'inflation des lois, in EssaIs suR LES LoIS (Paris, Répertoire notariat Defrenois, 1979).

145 See the title of an article in the International Herald Tribune, May 18, 1979: Pesticide Control in U.S. Is Administrative Jungle.

146 See Rothstein \& Ross, Environmental Law, 1977 Annual Survey of American Law $303,363-64$.

147 (New York, Basic Books, 1978). Professor Donald Dewey, reviewing the book in 87 YALE LAW JOURNAL 1516 (1978) and challenging the author's conclusions, writes however: "I 
Reluctantly, I would even ask about social regulation the question that I have asked about economic regulation: should we try to fight every evil we meet? Or should we try to concentrate on the most important ones and adopt for some others a polity of "benign neglect"? It is a tragedy, of course, to feel bound to ask such questions. It implies a failure and a denial of access to some forms of justice. When we think, however, to take but one example, of the amount of social legislation passed by the Congress of the United States under the leadership of President Johnson ${ }^{148}$ and of the disappointing results, we can hardly avoid the question.

It would be naive to think that all critics of the present state of regulation are disinterested. Some of them seek freedom in order to abuse it; others have daily experiences of the burdens and defects of regulation, but forget about the benefits it brings, taking them for granted. Still, it would be simplistic to consider that this is always the case. One does not need a pre-Roosevelt mentality to be of the opinion that the present explosion of regulation creates a problem for our societies and for the satisfactory working of the welfare state. Certainly, we should not blindly follow our inclinations and make new regulations as soon as we discover some evil. We cannot deceive ourselves with the illusion that we can eradicate all social evils.

I submit, therefore that we should, in addition to various propositions which have already been put forward:

a) concentrate economic and social regulation on what appears to be of significant importance;

b) bring the concerned persons or their representatives as much as possible into the decision-making process; ${ }^{149}$

c) pay greater attention to the harmonization of our different economic and social policies;

d) pay greater attention to the degree and quality of the implementation of our policies;

e) periodically review the practical consequences of regulation in a particular field and try to assess, difficult as it may be, its merits, its weaknesses and its drawbacks; ${ }^{150}$

share his concern about the drift of antitrust, especially the explosion of private damage suits that reward the litigious and increase the cost of doing business." Id. at 1525 .

148 See A. Tunc, Les Etats-Unis: Comment ils sont gouvernés (Paris, Librairie général de droit et de jurisprudence, 3rd ed., 1973).

149 See note 87 and accompanying text supra.

150 Many examples could be given of the need for periodic reassessments. For instance, sociologist James Coleman, whose study in the mid-1960's has been widely used in the United 
$f$ periodically undertake consolidation or codification of the regulations relevant to a certain field ${ }^{151}$ (an example in the field of economic regulation is the Federal Securities Code, which was prepared by the American Law Institute and Professor Louis Loss and which should greatly improve accessibility to securities regulation as well as its substance); and

g) promote as much as possible fairness through self-regulation and agreements between conflicting interests. ${ }^{152}$

States to support school desegregation, now says that it is a "mistaken belief" that black students learn better in integrated classrooms. During the last decade, research throughout the United States has shown that "it is not the case that school desegregation, as it has been carried out in American schools, generally brings achievement benefits to disadvantaged (black) children." In some situations, desegregation has brought slight gains in black achievements, but in many others there has been no change or a slight loss. Even though he argued a decade ago that "integration would bring about achievement benefits," Mr. Coleman now says, "it has not worked out this way in many of the school desegregation cases since that research. Thus what once appeared to be fact is now known to be fiction." Mr. Coleman; of the University of Chicago, presented his new conclusions in a paper in April 1978. He repeated them in an interview given to Lawrence Feinberg and reproduced in the International Herald Tribune of September 18, 1978.

Another example may be given. An American convict has confessed to a Senate subcommittee to having filed "scores" of requests under the Freedom of Information Act of 1975, for himself and fellow inmates, "to try to identify informants" and "eradicate them." TIME, September 25, 1978. On the other hand, in France, it quite often happens that honest citizens, according to G. Braibant, "do not know that they have a right to know." Le Monde, March 6, 1979.

On the limits of the power of the courts to contribute to social justice, see D. Horowirz, The Courts and Social Policy (Washington D. C., The Brookings Institution, 1977); see, however, the concluding remarks in this reporter's review of the book, 1978 REVUE INTERNATIONALE DE DROIT COMPARÉ 905, 907.

151 See L. Scarman, supra note 116, at 81-82, proposals 4) and 5).

152 See note 56 and accompanying text supra. See also a recent piece of information:

West German automakers have agreed to reduce fuel consumption of their cars by an average of 10 to $12 \%$ by 1985 .

Under an agreement with the Economics Ministry, the auto producers yesterday also pledged to adopt by the third quarter of 1980 industry-wide norms for testing fuel consumption and installing a guage in autos to measure fuel usage under various driving conditions.

The agreement entered into voluntarily by the producers signals the first time that the nation's auto industry has actually pledged to meet specific targets on fuel consumption.... A ministry spokesman said that there were no plans to invoke penalties for failure to meet the goal or set up any administrative apparatus to police the industry's efforts. He said that supervision of the carmakers' performance would probably be taken up by private consumer organizations....

International Herald Tribune, May 2, 1979. 


\section{E. The Impossible Quest for Justice}

We should not deceive ourselves. I have suggested in good faith some remedies to the present situation, but the legal system is likely to remain largely distant and strange to many of those whom we would like to protect. For years and years, man received protection through family and social solidarity. This social order has been destroyed, partly as a result of our new individualistic (and legitimate) expectations, partly as a result of industrialization and urbanization. Economic regulation is a poor substitute for social ethics; social security, a poor substitute for spontaneous community solidarity. But both are unavoidable for the protection of man in our present societies. We are certainly heading toward more regulation, even though no regulation will ever protect us from abuses on the part of the press ${ }^{153}$ or from gross errors in public opinion. ${ }^{154}$ And we shall continue being caught between contradictory expectations.

In a recent study on social justice, David Miller considers social justice to be based on "rights," "deserts" and "needs" and asserts that "rights" on the one hand, and "deserts" and "needs" on the other, are contingently in conflict, but that "deserts" and "needs" are necessarily in conflict. ${ }^{155}$ If such is the situation, we shall always strive for justice without ever being able to reach it, not only because of our weaknesses, but because justice is unattainable and because we are constantly taking a higher view of the demands of justice. Our quest will be self-elusive. But our realism should never turn to cynicism. We should lose illusions, not faith - and we might be in danger of losing the latter. ${ }^{156}$ It is the dignity of man to pursue the

153 See, e.g., H. Böll, Die verlorene Ehre der Katharina Blum (Cologne, Kiepenheuer \& Witsch, 1974).

154 See, e.g., G. Perrault, supra note 10.

155 D. Miller, supra note 125 , at 27-28.

156 See the following editorial of the New York Times, October 26, 1976:

One of the healthiest developments of the 1960's was the accessibility of the Warren court and the concurrent development of what the law professors call "a vigorous and skillful public interest bar." During a decade when U.S. public officials were urgently promising minorities and young people that the American institutions were open to orderly change without recourse to the streets, it was the federal judiciary that most consistently supported the claim. The courts gave rise to a belief in the country that no matter how much injustice one perceived, the peaceful struggle for justice could bear fruit in concrete ways that actually affected people's lives.

The sense that the court is nourishing justice is waning in the country to- 
quest for justice. And it is the honor of the General Editor of the Access-to-Justice Project Series to have invited us to pursue it, and to have given the impetus to such an amount of comparative research and thinking that, under his guidance, we may hope to open the door to some progress.

day. Public interest lawyers now often seek to avoid the Supreme Court, and the promise of orderly institutional changes seems dimmer now than it did a decade ago. It is not just young public interest lawyers who have faced "some disappointments" at this turn of events. It is everyone who cherishes the ideal of a society in which the robust pursuit of justice is not simply possible, but is actively encouraged at all levels of public and private activity. 

APPENDIX

ACCESS TO JUSTICE CONFERENCE, OCTOBER 15-18, 1979

LIST OF PARTICIPANTS

Pierre Bellet (France) - Premier Président, Court of Cassation; President, Conseil d'administration de l'Ecole nationale de la magistrature; President, Commission nationale de l'informatique et des libertés.

Gary Bellow (USA) - Professor of Law, Harvard University; Director, Legal Services Institute; Deputy Director, Legal Aid Agency for Washington, D. C., 1962-65; Administrative Director, United Planning Organ, Washington, D. C., 1965; Deputy Director, California Rural Legal Assistance, 1966-68; Member of: Board of Directors, N.L.A.D.A.; National Advisory Committee to OEO on Law and Poverty; Civic Legal Aid Committee, N.L.A.D.A.; Consultant, Children's Defense Fund.

Erhard Blankenburg (Germany) - Head of Research Group on Legal Services, Wissenschaftszentrum, Berlin; Professor of Sociology, University of Amsterdam (formerly, University of Freiburg); Advisor, German Ministry of Justice (State and Federal level) and the Council of Europe.

Gordon Borrie (Great Britain) - Director General of Fair Trading, since 1976; barrister; formerly Professor of English Law, Dean of the Faculty of Law and Director of the Institute of Judicial Administration, Birmingham University; Member of: Law Commission Advisory Panel on Contract Law, since 1966; Council, Consumers' Association, 1972-76; Equal Opportunities Commission, 1975-76.

Dan Bradley (USA) - President, Legal Services Corporation.

Brendan Byrne (USA) - Governor of the State of New Jersey, since 1973: former Vice President of the National District Attorney's Association; former Superior Court Judge.

Mauro Cappelletti (Italy) - Professor of Law, European University Institute, University of Florence and Stanford University; Director, Accessto-Justice Project and General Editor of the Florence Access-to-Iustice Series; Vice President, International Association of Legal Science (UNESCO); Member of: British Academy; Royal Academy of Sciences, Letters and Arts, Belgium.

René David (France) - Formerly Professor of Comparative Law, University 
of Aix-Marseille and Professor at the European University Institute; draftsman, Civil Code of Ethiopia; Erasmus Prize, 1976.

Giuseppe Di Federico (Italy) - Professor of Political Science, Head of the Institute for Politics and Administration, University of Bologna; Member, Governmental Commission for Legislative Reforms.

Giuseppe Di Gennaro (Italy) - Director General, Division of Penal Affairs, Ministry of Justice, Rome.

Claus-Dieter Ehlermann (European Communities) - Director General, Legal Service, Commission of the European Communities.

Niels Ehrenreich (Denmark) - Consumer Ombudsman of Denmark; Ministry of Justice, 1947-62; Judge, 1962-75; Member of several law committees dealing with trade and consumer legislation.

Arthur J. England, Jr. (USA) - Chief Justice, Supreme Court of Florida; formerly Special Counsel to the Florida Legislature and Consumer Advisor to the Governor of Florida; draftsman, Deceptive and Unfair Practice Law and Administrative Procedure Act of Florida.

Lawrence Friedman (USA) - Professor of Law, Stanford University; Fellow, Center for Advanced Study in Behavioral Sciences, 1974-75; President, Law and Society Association; Member, American Academy of Arts and Sciences.

Hans-Peter Furrer (Council of Europe) - Head of Division I, Directorate of Legal Affairs, Council of Europe.

Giorgio Gaja (Italy) - Professor and Dean of the Faculty of Law, University of Florence.

Marc Galanter (USA) - Professor of Law and of South Asian Studies, University of Wisconsin; formerly Faculty Fellow of the American Institute of Indian Studies, and Consultant to the International Legal Center; former Editor of the Law and Society Review; Senior Project Advisor, University of Wisconsin-University of Southern California Civil Litigation Research Project; Member, Council on Role of Courts; Trustee, Law and Society Association.

Richard N. Gardner (USA) - U. S. Ambassador to Italy since 1977; former Professor of Law, Columbia University.

Bryant Garth (USA) - Assistant Professor of Law, Indiana University; Coeditor, Florence Access-to-Justice Project Series, Vols. I and III.

Valerio Grementieri (Italy) - Associate Professor of Law, University of Siena; Associate, Institute of Comparative Law, University of Florence.

Ingvar Gullnäs (Sweden) - Justitiekansler of Sweden; formerly of the Ministry of Justice; draftsman, report on the reform of legal aid in Sweden.

Charles Halpern (USA) - Professor of Law and Director, Institute for Public Interest Representation Georgetown University; former Director, Center for Law and Social Policy.

Geoffrey Hand (Ireland) - Professor of Law, European University Institute; formerly Dean of University College, Dublin.

Jan Hellner (Sweden) - Professor of Law, University of Stockholm; draftsman, Swedish Consumer Sales Act, 1973; rules on Unfair Contract Terms, 1976; The Consumer Insurance Bill, 1979. 
Klaus Hopt (Germany) - Professor of Law, European University Institute and University of Tübingen.

Sanford Jaffe (USA) - Officer in Charge, Division of National Affairs, Government and Law, Ford Foundation.

Jon Johnsen (Norway) - Lecturer, Institute for Sociology of Law, University of Oslo; Director of the "Juss-Buss" Legal Aid Project of the University of Oslo; Research Worker, Ministry of Justice 1976-78.

Earl Johnson, Jr. (USA) - Professor of Law, University of Southern California; Co-Director, Florence Access-to-Justice Project; Deputy Director, Neighborhood Legal Services Program, 1964-65; Deputy Director OEO Legal Services Program, 1965-66; Director 1966-68; Director, Program for the Study of Dispute Resolution Policy, Program for Justice System Research.

Max Kohnstamm (Netherlands) - President, European University Institute.

Takeshi Kojima (Japan) - Professor of Law, Chuo University; Director, Japanese Association of the Law of Civil Procedure; Chairman, Committee on Consumer Participation in Administrative Procedure; codraftsman, Model Class Action Statute, 1978.

Hein Kötz (Germany) - Co-Director, Max-Planck-Institute for Foreign and Private International Law, Hamburg; former Professor of Law, University of Konstanz; former Judge of the Court of Appeals, Karlsruhe/Freiburg.

Ludwig Krämer (European Communities) - Environment and Consumer Protection Service, Commission of the European Communities.

Robert Krieps (Luxembourg) - Professor of Law, Free University of Brussels; former Minister of Justice and Minister of Education, Luxembourg; Legal Advisor to the Trade and Professional Unions, and to the Luxembourg Union of Consumers.

Ernest Krings (Belgium) - Advocate General, Belgian Court of Cassation; Professor, Free University of Brussels; former Member, Royal Commission for the Reform of the Legal System; draftsman, Judicial Code of Belgium.

Ole Lando (Denmark) - Professor, Copenhagen School of Economics and Business Administration; Director, Institute of European Market Law.

Phil Leask (Great Britain) - Administrator, Law Centres Federation; former member of the Camden Law Centre.

Paul Leleux (European Communities) - Senior Legal Advisor, Commission of the European Communities.

Nils Mangård (Sweden) - Judge of Appeal; President, Public Consumer Complaints Board; former President, Federal High Court, Eritrea; former Advisor and Draftsman, Ministry of Communications, Ministry of Public Health and Social Affairs and Ministry of Justice; Member, International Council for Commercial Arbitration.

Edward McConnell (USA) - Director, National Center for State Courts.

Yves Mény (France) - Professor of Law, European University Institute and University of Rennes.

Wouter Meurs (Netherlands) - Head of Division of General Legal Affairs, 
Ministry of Justice, the Netherlands; Founding Member, Amsterdam Law Center and Netherlands Association for Legal Assistance.

David Molony (Ireland) - Senator, Republic of Ireland; former Chairman, Council of the Free Legal Advice Centres; Solicitor.

Derek Oulton (Great Britain) - Deputy Secretary, Lord Chancellor's Office; Deputy Clerk of the Crown in Chancery.

Jan Peek (Netherlands) - Head of the General Legal Assistance Branch, Ministry of Justice, the Netherlands; formerly Lecturer in Law, State University of Leiden.

Jean-Pierre Plantard (France) - Head of the Office of European and International Law, Ministry of Justice of France; advocate and former judge; formerly Officer in charge of Public Relations at the Ministry of Justice (where he organized the Information and Public Relations Bureau; and was an active member of the "Comité des usagers de la Justice").

Tomas Roseingrave (European Communities) - Vice Chairman, the Economic and Social Committee of the European Communities.

Maurice Rosenberg (USA) - Assistant Attorney General of the U.S., Office for Improvements in the Administration of Justice; Professor, Columbia Law School; Member, American Academy of Arts and Sciences.

Ivo Samkalden (Netherlands) - Professor of Law, University of Leiden; former Minister of Justice of the Netherlands; former Mayor of Amsterdam.

Frank Sander (USA) - Professor of Law, Harvard University; Member of: American Arbitration Association; Federal Mediation and Conciliation Service.

Paul Schuster (Germany) - Ministerialrat, Ministry of Justice, Federal Republic of Germany.

Martin Shapiro (USA) - Professor of Law, University of California at Berkeley; Member of: Law and Society Association (Trustee, 1970-77); American Academy of Arts and Sciences.

Sir Andrew Shonfield (Great Britain) - Professor and Head of the Department of Economics, European University Institute; former Director, Royal Institute of International Affairs, London.

Linda Singer (USA) - Executive Director, Center for Community Justice; Fellow, Research Institute on Legal Assistance of the Legal Services Corporation; Legal Advisor to the Special Master, Federal District Court of Rhode Island; consultant to various government agencies on issues connected with mediation and other forms of dispute resolution.

Marcel Storme (Belgium) - Senator, Kingdom of Belgium; Professor of Law, Ghent University.

Harry Street (Great Britain) - Professor of Law, Manchester University; Member, Monopolies and Merger Commission; former Chairman, Committee on Racial Discrimination; Chairman, Manchester National Insurance Local Appeals Tribunal.

Francis Sutton (USA) - Deputy Vice-President, Ford Foundation.

Criton Tornaritis (Cyprus) - Attorney-General of the Republic of Cyprus; 
formerly District Court Judge, Solicitor General, member of the Commission for the Codification of the Law.

Nicolò Trocker (Italy) - Professor of Law, University of Siena; Associate, Institute of Comparative Law, University of Florence.

David Trubek (USA) - Professor of Law, University of Wisconsin; Director, Civil Litigation Research Project; Member of: American Sociological Association, U. S. Commission on Civil Rights; Research Director, Center for Public Representation, Inc.

Louise Trubek (USA) - Executive Director, Center for Public Representation, Inc.

André Tunc (France) - Professor of Law, University of Paris I; Member, Paris Bar; Counsellor, International Monetary Fund, 1944-50; Legal Advisor, United Nations Economic Commission for Europe, 1957-58.

John Weisner (USA) - Research Fellow, Law Department, European University Institute; Co-editor, Florence Access-to-Justice Project Series, Volume II.

Michael Zander (Great Britain) - Professor of Law, London School of Economics; Legal Correspondent of "The Guardian."

Fred Zemans (Canada) - Professor of Law, Osgoode Hall Law School. 

STAMPATO A FIRENZE

NEGLI STABILIMENTI TIPOGRAFICI

«E. ARIANI »E «L'ARTE DELLA STAMPA »

FEBBRAIO 1981 



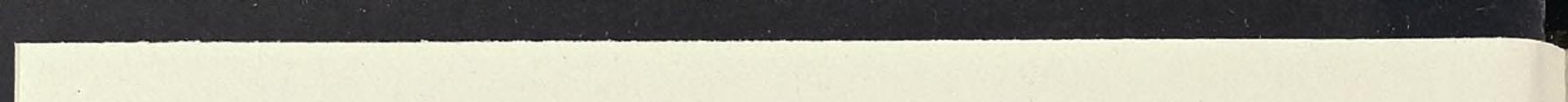


Mauro Cappelletti, who was born in Italy in 1927 and studied at the Universities of Florence and Freiburg i. Br., is Professor of Law at the University of Florence and Stanford University. Since 1976 he has also been a Professor in the Law Department of the European University Institute. In addition, Professor Cappelletti has held visiting appointments at Harvard University and the University of California at Berkeley. He has been awarded doctorates honoris causa by the Universities of Aix-Marseille and Ghent, and is a foreign member of the British Academy and the Royal Academy of Sciences, Letters and Arts of Belgium. He is Vice-President of the International Association of Legal Science and Editor-inChief of the volume on Civil Procedure of the International Encyclopedia of Comparative Law. From 1973 to 1979 he directed a project entitled "Access to Justice: a Program to Study and Improve Dispute Resolution in Contemporary Societies," sponsored by the Ford Foundation, the Italian National Research Council and the European University Institute. His recent publications include: Access to Justice, Volumes I-IV (editor, 1978-79); Comparative Constitutional Law: Cases and Materials (with W. Cohen, 1979); New Perspectives for a Common Law of Europe (editor, 1978); Toward Equal Justice (with J. Gordley and E. Johnson, Jr., 1975); Public Interest Parties and the Active Role of the Judge (with A. Jolowicz, 1975); Proceso, Ideologías, Sociedad (1974); Les garanties fondamentales des parties dans le procès civil (with D. Tallon, 1973).

Professor Cappelletti is currently directing an international research project on "European Legal Integration in the Light of the American Federal Experience," which includes a study of the problems of access to justice on a transnational level. 



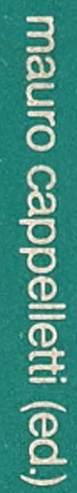

วิํำ

इष

इठ

ब들

तె तี

का

कृ

th 